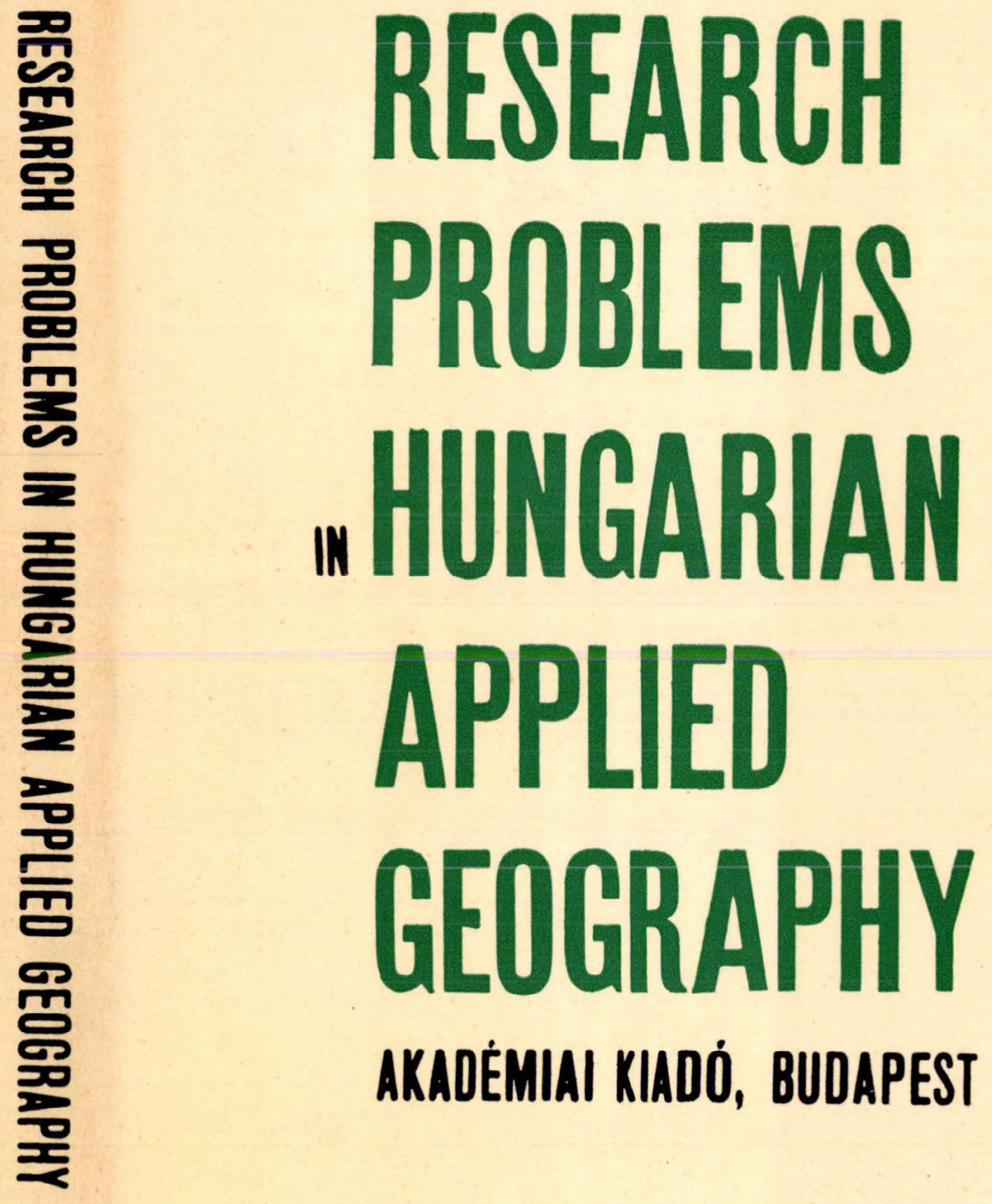

画同酉 


\section{RESEARCH PROBLEMS \\ IN HUNGARIAN APPLIED GEOGRAPHY}

\section{STUDIES IN GEOGRAPHY}

The first part of this volume dealing with the research problems and recent results of applied geography in Hungary contains physical, and its second part, economic geographical studies. Based on a modern classification of the regions, the research team of Hungarian applied geography has set the task for geomorphological mapping to assess the ways of agricultural land utilization throughout the country. In continuation of the reports presented in former volumes of this series, the authors of this book wish to supply further information about the possibilities of up-to-date soil protection, soil conservation, erosion prevention and reasonable land utilization in general. They also give suggestions concerning soil-geographical and microclimatological investigations, and survey the topical fields where research has been most promising in the last years, such as regional connections of the different mechanisms of internal migration, the actual situation of the detached tanya farms - the existence of which has become highly problematical, owing to the collectivization of agriculture-, the geographical types of animal husbandry, ete.

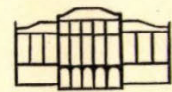

AKADÉMIAI KIADÓ

Publishing House of the Hungarian Academy of Sciences

Budapest 
RESEARCH PROBLEMS IN HUNGARIAN APPLIED GEOGRAPHY 
STUDIES IN GEOGRAPHY IN HUNGARY, 5

\section{Chief Editor:}

MÁRTON PÉCSI

Editorial Board:

GYÖRGY ENYEDI

SÁNDOR MAROSI

LÁSZLÓ SIMON

JENÓ SZILÁRD 


\section{RESEARCH PROBLEMS IN HUNGARIAN APPLIED GEOGRAPHY}

edited by

BÉLA SÁRFALVI

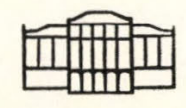

A K A DÉMIAI KIA D Ó, BUDAPEST 1969 
This volume of selected papers was presented for the Twenty-first Congress of the International Geographical Union, Delhi 1968

\section{Translated}

by

Bálint Balkay, Endre Dudich and Béla Kecskés

Translation revised

by

Paul A. Compton

(C) Akadémiai Kiadó, Budapest 1969

Printed in Hungary 


\section{CONTENTS}

Pécsi, M. and Somogyi, S.

Subdivision and classification of the physiographic landscapes and geomorphological regions of Hungary

Simon, L.

Ground-water aquifers and pressure distribution

Ádám, L.

Geomorphological research and mapping in strongly eroded areas

Jakucs, P., Marosi, S. and Szilárd, J.

Microclimatological investigations within the scope of complex physiographic landscape research in Hungary

Góczán, L.

Applied soil geography and agriculture

Kazó, B.

Determination of water household parameters of sloping soil surfaces measured by the aid of a "rainfall simulator"

Pécsi, M.

The clarification of some terms used in geomorphology

Sárfalvi, B.

Various mechanisms of internal migration in Hungary

Lettrich, E.

The Hungarian tanya system: history and present-day problems

Petri, E.

The collectivization of agriculture and the tanya system

Asztalos, I.

A geographical study of stockbreeding in Hungary 


\section{SUBDIVISION AND CLASSIFIGATION OF THE PHYSIO- GRAPHIC LANDSCAPES AND GEOMORPHOLOGICAL REGIONS OF HUNGARY}

by

M. PÉCSI and S. SOMOGYI

\section{THE SUBDIVISION OF HUNGARY INTO LANDSCAPE ELEMENTS}

Landscape subdivision partly based upon landscape typology is made increasingly necessary by ever more urgent social and economic requirements. Therefore landscape typology, one of the more important research topics of our branch of science, is today gaining a greater and more complex significance.

It is the awakening of scientific and social interest that calls for a coordination of physiographic landscape classification and subdivision on an international and continental level also. Research in this field requires that, in order to establish a hierarchy of physiographic landscape units, suitable basic principles be laid down and exact methods developed.

\section{A HIERARCHY OF LANDSCAPE CLASSIFICATION}

A hierarchy of classification of physiographic landscapes is, in our opinion, useful and meaningful for the purposes of science, the economy and everyday life, although those established in international practice are rather different. ${ }^{1}$

As to the subdivision of continents into physiographic landscape units, there are two more or less opposite trends which, however, in certain of their aspects complement rather than oppose one another (Sochava 1956). On the one hand, there is the subdivision of the continents into large morpho-genetic regions, and on the other the division into geo-zones delimited on the basis of the vegetation and soil zones developed under the interaction of climate and orography. The delimitation of lower-level landscape units is made possible by the combination of morphogenetic and orographic elements as both local features and zonal characteristics. The distinction of the units at the lowest level of the hierarchy is based on the so-called principle of landscape homogeneity.

Still, the terms denoting the smallest homogeneous units of a landscape hierarchy, which have been coined and proposed by various authors or schools of thought-facies, Ökotop, Fliesen, Ökopotip, uroshchicha, Mikro-

1 There have been a number of recent proposals as to the hierarchical classification of physiographic landscapes and regions (Cys 1961, Isachenko 1965, Kondracky 1964, 1965, Meynen-Schmithüsen 1953, Mihailov 1964, Neef 1963, Sochava 1956, Solntzev 1962). Kondracky distinguished the hierarchic units obsar, shtrefa (podobsar), provincia, podprovincia, macroregion, mezoregion, and microregion. In his more recent classification, Sochava (1967) distinguished (a) primary or planetary geozones-poyas-and within these (b) great regions - the oblasts - which are in effect large structural units, i.e. plains, mountain chains, and platforms. These he subdivided into secondary or provincial units: (a) zones, (b) provinces, (c) rayons. Within the rayons he set up a third-order-topological-subdivision of (a) coralites, (b) uroshchichas. The uroshchicha is composed of landscape elements (facies). 


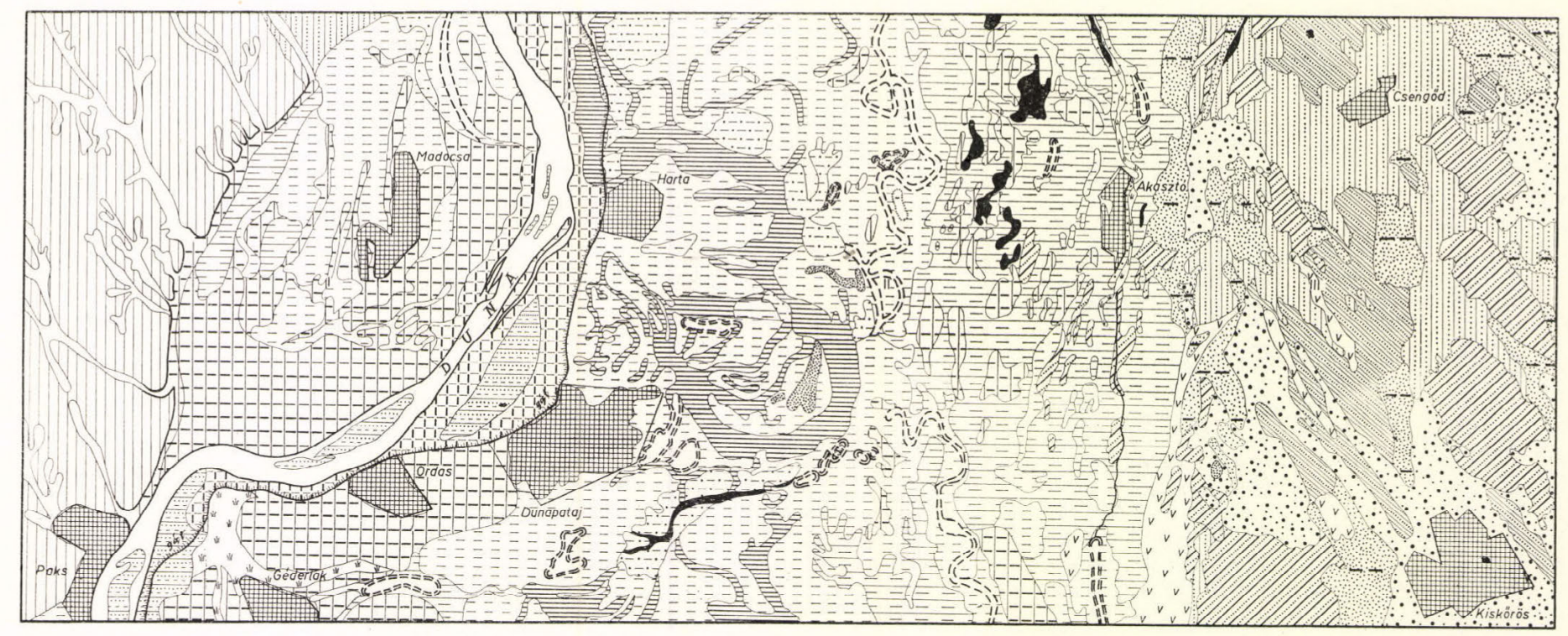

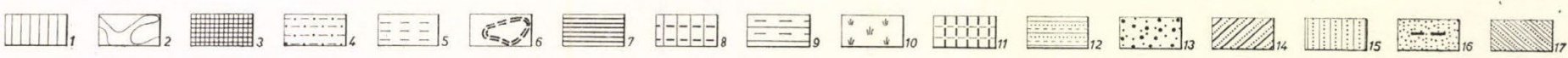

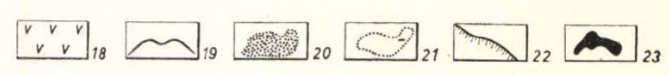

Fig. 1. (For legend see page 9.)

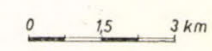


chore, etc.-are far from being identical (Gvozhdetsky, Isachenko, Kondracky, Neef, Marosi-Szilárd, Schmithüsen and others). Hence, the reconciliation and detailed correlation of diverging views is an indispensable prerequisite for further international cooperation.

Similarly, there is no unity of view and no generally accepted practice as to the nomenclature of the higher-order landscape categories. However, with due attention to the best elements in all the classifications proposed so far, the hierarchy of geozone, subcontinent, megaregion, macroregion, mesoregion, and microregion seems to be the most acceptable.

Fig. 1. Types of landscape ecology and morphofacies in the morphological divisions and the neighbourhood of the Mezöfold, the Danube Riverine and the ridge of the Danube-Tisza Interfluve. (Plotted by S. Somogyi on the basis of the morphological maps of M. Pécsi and J. Szilárd.)

Ecological facies

$1=$ Loess tableland-scene of agricultural production; $2=$ Narow, deep valleys-sites of meadows, pastures, and fish-ponds; $3=$ Terrace island, sites of settlements; $4=$ High, sandy flood-plain under agricultural cultivation; $5=$ High, silty flood-plain under agricultural cultivation; $6=$ High flood-plain flats, meanders with "szik"--covered meadows and pastures; $7=$ Periodically waterlogged places on the high flood-plain; $8=$ Low flood-plain with "szik"-covered meadows and pastures; $9=$ Low flood-plain, periodically waterlogged, with reeds and peat-meadows; $10=$ Meanders with high sedges; $11=$ The higher level of the interspace of the Danube levees with elm-ash-oak galleries (with eventual arable land); $12=$ The lower level of the interspace of the Danube levees with willow-poplar galleries and pastures; 13 = Wind-blown sand with "sand puszta grass", poplar-juniper grove; $14=$ Fixed sand with vineyards and orchards; $15=$ Loessic-sandy surfaces with arable fields; $16=$ Flats, fen windows with meadows and pastures; $17=$ Waterlogged places with reeds and meadows; 18 = Natron lakes, peat-meadows; $19=$ Steep bank, escarpment, liable to erosion; $20=$ Floodless surface with gardens and vineyards; $21=$ "Szik"-covered flats, periodically waterlogged; 22 = Levees, dams (anthropogenic landscape element); $23=$ Standing waters Morphofacies

$1=$ Tableland covered by typical and redeposited loess; $2=$ Erosion-derasion valleys; $3=$ Latest Pleistocene terrace island covered by loessic, calcareous, and sandy silt; $4=$ High flood-plain covered by flood-deposited sand and sandy silt; $5=$ High flood-plain covered by loessic, sandy and calcareous silt; $6=$ Lower Holocene meanders with redeposited loessic silt, sandy silt, locally with fluviatile sand; $7=$ Lower Holocene meanders filled with silt, meadow and bog clay; $8=$ Low flood-plain covered by silt, calcareous silt, and clay; $9=$ Low flood-plain covered by bog clay, peat, and peaty earth; $10=$ Upper Holocene meanders with bog clay and water; $11=$ Recent high flood-plain covered by sediments (periodically waterlogged); $12=$ Recent low flood-plain with flood-laid sediments (periodically inundated); $13=$ Lower Holocene- Pleistocene wind-blown sand surface with dunes and other types of half-fixed sand features; $15=$ Sandy loess, loessic sand, infusion loess, loessic silt; $16=$ Calcareous-silty sand, sandy silt; $17=$ Calcareous silt in the furrows between the dune rows; $18=$ Basins filled with peat and peaty earth; $19=$ Escarpment due to faulting and erosion; $20=$ Flood-plain islands covered by fixed sand with calcareous silt; $21=$ Dammed flood-plain depressions; $22=$ Levees of the Danube; $23=$ Dammed depressions with permanent water body 


\section{TAXONOMIC UNITS OF PHYSIOGRAPHIC LANDSCAPE CLASSIFICATION}

\section{A. Microregion (landscape-element group, ecological facies group)}

Within the hierarchical system of landscape classification, macroregions are those taxonomic units of the terrestrial surface which are characterized by the largely uniform action and influence of most landscape-forming factors, and which because of this are clearly distinguished from the other macroregions adjacent to them. In Hungary, the Great Plains region is such a unit.

If, however, one wants to delimit the areas characterized by the full homogeneity of all factors, one has to consider much smaller units, the so-called ecological facies. ${ }^{2}$ Ecological facies-the smallest homogeneous landscape areas-are elements of uniform evolution and structure, where the water regime, vegetation cover and soil type are identical over the whole unit (Fig. 1). Such ecological homogeneity does not, of course, extend to larger regions, except perhaps to the meadow and swamp regions of the Little and Great Plain in Hungary. In the mountains, it is the bottoms of small basins, the slopes, the valley flanks and interfluvial ridges of identical exposure, that belong to a given facies type (Fig. 2).

The ecological facies of a restricted region, exhibiting similar traits due to the uniformity of action of several, but not all, factors constitute a repetitive mosaic, forming an ecological facies group. According to several authors (Schmithüsen, Troll, Neef), it is these facies groups that constitute the lowestorder topological units of physiographic landscapes. A mosaic of genetically identical or similar ecological facies groups (Ökotopgefüge, uroschchicha, Mikrochore) constitutes part of a landscape, "landscape-element", "Landschaftsteil".

The combination of landscape elements of varying areal extent and features gives rise to micro- and mesoregions. Microregions consist of a mosaic of relatively few landscape elements, which are closely related or even identical. The repetition of microregions may constitute a microregion group (Pest Plain, 1.1.1).

\section{B. Mesoregion}

Mesoregions consist of a mosaic-like repetition of various types of microregion. Even among the heterogeneous ecologic facies groups that make up a microregion, some factors are necessarily identical. It is their uniform evolutionary and structural history that makes them stand apart within the greater relief units, e.g. mountains and plains. For instance, the Pest Plain (1.1.1) and the Csepel-Mohács Plain (1.1.2) differ in certain aspects of local climate, ground water regime, soil and vegetation cover, but in evolution, structure and morphology they exhibit considerable similarity. This is why

2 A number of terms have been introduced for these smallest units, such as site, Fliesen, Ökotop, landscape facies etc. Some authors distinguish also "natural ecotopes" and "anthropogenic ecotopes": the latter having been developed or modified by human influence, e.g. ploughlands, irrigated meadows etc. (Schmithüsen). 
it is possible to group these microregions, certain hydrographic and pedogeographic differences notwithstanding, into one and the same mesoregion, called "the Danube Flood Plain" (1.1).

\section{Macroregion}

The principal trait of a macroregion is that it covers a section of a relief type (plains, rolling country or hills), in which the majority of the landscape-
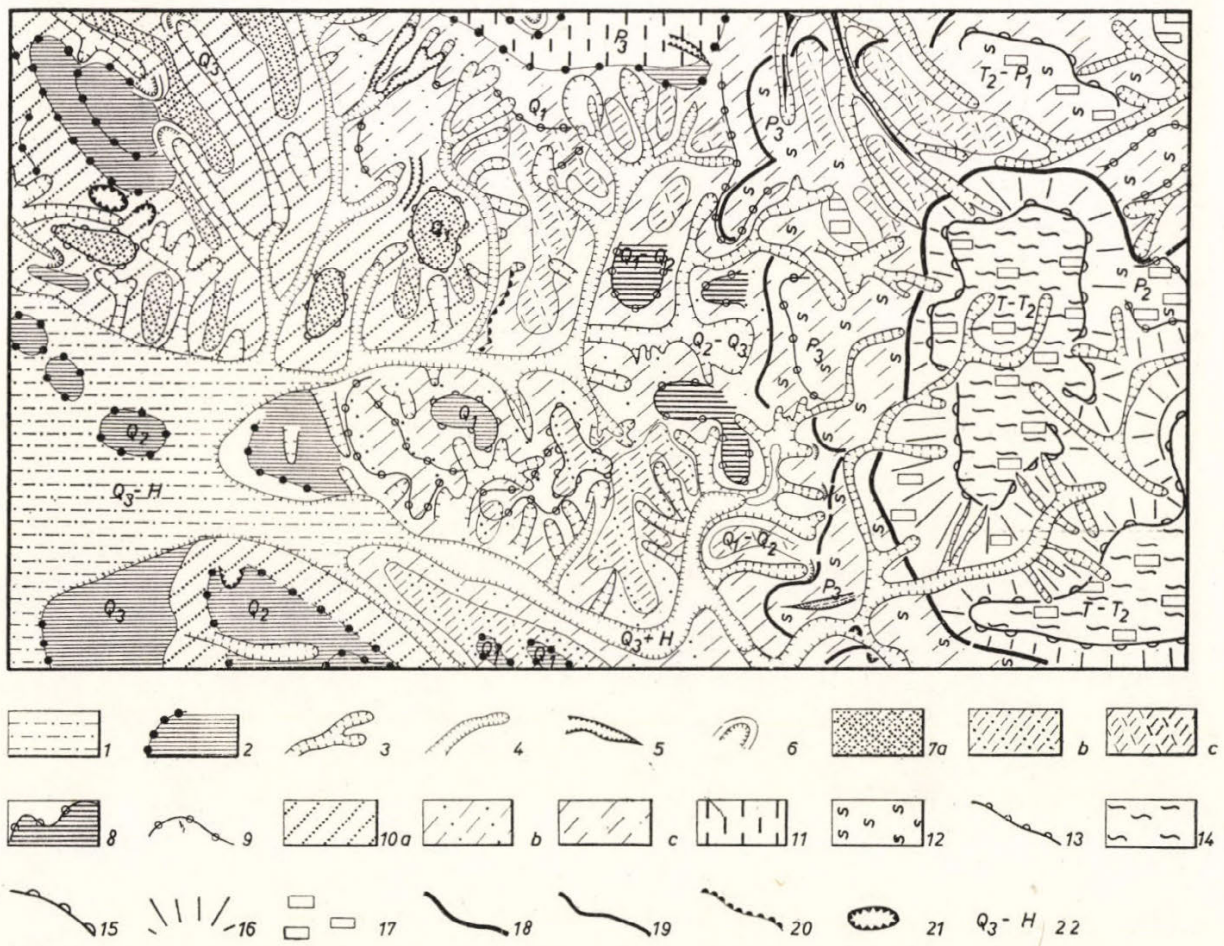

$0 \quad 10 \cdot 20 \quad 40 \quad 50 \mathrm{~km}$

Fig. 2. Types of morphological facies and their groups on the west border of the Gerecse Mountains (by M. Pécsi)

$1=$ Sandy, silty valley floor; $2=$ River terrace surface; $3=$ Derasion-carved dry valleys and karst valleys; $4=$ Valleys carved by rivulets; $5=$ Ravines and gullies; $6=$ Broad valley heads (derasion valley heads); $7=$ Erosion-derasion inselberg, intra-valley ridge; (a) sand, (b) sandy loess, (c) slope-deposited loess; $8=$ Cryoplanation ridges and steps; $9=$ Cryoplanation step; $10=$ Hill and valley slopes: $(a)$ sand, $(b)$ sandy loess, $(c)$ slope-deposited loess; $11=$ Loess plateau; $12=$ Pediment; $13=$ Piedmont step border; $14=$ Mountain top surface (peneplain); $15=$ Bench; $16=$ Steep limestone slope; $17=$ Landforms made up of limestone; $18=$ Boundary of a morphological division within a mountain region; $19=$ Boundary of pediment; $20=$ Sliding slope; $21=$ Artificial (antropogenic) trenches; $22=$ Age of the surface; $\mathrm{T}=$ Tertiary; $\mathrm{T}_{2}=$ Upper Tertiary; $\mathrm{P}_{1-3}=$ Lower-Middle-Upper Pliocene; $\mathrm{Q}_{1-3}=$ Lower-Middle-Upper Pleistocene; $\mathrm{H}=$ Holocene 


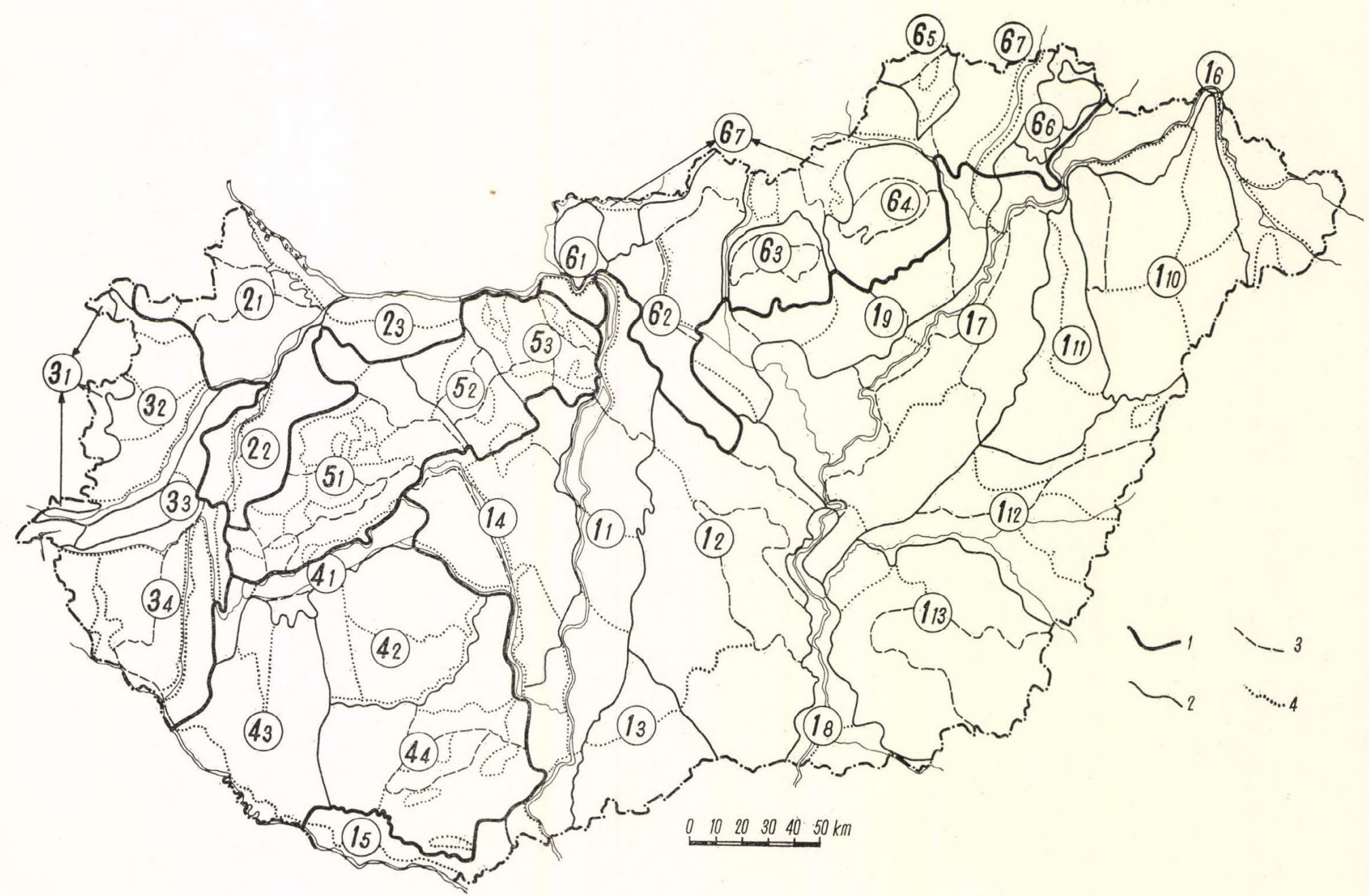

Fig. 3. (For legend see page 13.) 
forming factors, other than the relief, compose, on a regional scale, a largely uniform physiographic environment. For example, the Hungarian Plain is a basin filled with Tertiary and Quaternary deposits, having a continental-type climate and centripetal drainage network. Together these result in a woodedsteppe vegetation dissected by vague bands of floodplain lined with riparian forest, meadow and swamp and possessing a characteristic soil cover. The homogeneity of the relief often entails a similarity of mesoclimatic features, which tend to emphasize the distinctive traits of the macroregion.

With the exception of the Alpine foreland on the Western Hungarian border, the macroregions of Hungary correspond with the above definition. However, climatic, phyto- and pedogeographic factors justify a distinction between the Alpine foreland and the Little Plain. The distinctive features of the former emanate from the Alpine region which, although too weak to separate this area completely from the Carpathian Basins, are still strong enough to turn it into a separate macroregion.

The borders of the micro- and macroregion and those of higher order are zones of transition rather than sharp lines. The Alpine foreland is such a transitional area.

\section{Macroregion groups and megaregions, subcontinents}

Several macroregions of related features constitute a megaregion. The Great Hungarian Plain is part of the Carpathian Basin megaregion, outlined as a single unit by its uniformity of crustal structure.

Fig. 3. Physico-geographic landscapes of Hungary. Classification developed by M. Pécsi and S. Somogyi. Boundaries of some landscapes traced and their names introduced with co-operation of Z. Borsy, Gy. Lovász. S. Marosi, Z. Pinczés and J. Szilárd.

1. Macroregion 1.1. Mesoregion 1.11. Subregion 1.1.11. Micraregion; 1.1.11.1. Ecological facies group (part of mosaic of microregion)

1. The Great Hungarian Plain (Alföld); 1.1. The Danube Riverine; 1.2. Ridge of the Tisza Interfluve; 1.3. The Bácska Ridge; 1.4. The Mezőföld; 1.5. The Drava Riverine; 1.6 The Upper Tisza Riverine- 1.7. The Middle Tisza Riverine; 1.8. The Lower Tisza Riverine; 1.9. Alluvial Plain of the Northern Great Plain; 1.10. The Nyírség; 1.11. The Hajdúság; 1.12. The Berettyó-Körös Riverine; 1.13. The Körös-Maros Interfluve

2. The Little Hungarian Plain; 2.1. The Györ Basin; 2.2. The Marcal Basin; 2.3. The KomáromEsztergom Plain

3. West Hungarian Borderland; 3.1. The Subalpine Region; 3.2 The Sopron-Vas Plain; 3.3. The Kemeneshát; 3.4. The Zala Hill Country

4. The Transdanubian Hill Region; 4.1. The Balaton Basin; 4.2. The Outer Somogy; 4.3. The Inner Somogy; 4.4. The Mecsek Mountains and the Tolna-Baranya Hill Country

5. The Transdanubian Central Mountains; 5.1. The Bakony Mountains; 5.2. The Vértes and Velence Mountains; 5.3. The Dunazug Mountains

6. The Mountain Region of North Hungary; 6.1. The Mountain Region of the Danube Bend; 6.2. The Cserhát Mountains; 6.3. The Mátra Mountains; 6.4. The Bükk Mountains; 6.5. The North Borsod Mountain Region; 6.6. The Tokaj-Zemplén Mountain Region; 6.7. The NógrádBorsod Basins

$1=$ boundary of macroregion; $2=$ boundary of mesoregion; $3=$ boundary of subregion; $4=$ boundary of microregion 
The megaregion is the largest regional taxonomic unit because the grouping of megaregions into subcontinents is already at a planetary level. Over the subcontinental areas, and sometimes even within the mega- and macroregions, ecological zones have developed which are dependent on the global situation, or on orographic features, such zones being characterized by a high-degree of uniformity of climatic, phyto- and pedogeographic traits. Subcontinents are distinguished not only on the basis of structure and relief, but also on other important landscape-forming features such as distance from the sea and position relative to the planetary wind systems, both of which are profoundly influenced by structure and orography.

\section{E. Geozones}

Finally, megaregion groups, composed of megaregions and subcontinents, constitute the highest-order landscape units on earth, the geozones, which are developed by the major world climates. The decisive factor in the delimitation of a geozone is the homogeneous distribution of the radiant energy of the Sun over long intervals of time, which determines the numerous landscapeforming factors and, through them, the zonal arrangement of land forms.

Geozones can be subdivided directly into macroregions. Similarly, the other composite taxonomic units can be subdivided by dropping one or more of the intermediate stages, particularly where the intermediate levels cannot be distinguished on the basis of the interactions of the forces of nature.

The degree of landscape subdivision is determined in the final reckoning by suitability on the one hand, and by the availability of regional geographic information on the other.

\section{THE MAIN PRINCIPLES AND METHODS OF LANDSCAPE SUBDIVISION IN HUNGARY}

a. Prior to objective geographical research, landscape subdivision in Hungary was largely based upon tradition and on administrative areas. Most of the common landscape names more or less coincide with physiographic units (Nyírség, Hajdúság, Jászság, Belső-Somogy, Kemeneshát, Mezőföld, Tiszazug, Rétköz, etc.). Most of these are still distinguished as physiographic divisions, although not all are of the same order. This landscape subdivision which had its roots in the language did not cover the entire area of the country, nor did it always strictly delimit the individual units from each other. Even so, these spontaneous and traditional names have to a certain extent influenced the main lines of our present subdivision.

b. The scientific basis of our landscape subdivision has consisted of regional maps and monographs prepared by various natural scientists in the fields of geology, structure, climate, pedology, zoo- and phytogeography, hydrology and particularly geomorphology. The joint evaluation of this material provided 
a foundation on which to assess the integrated effects of all landscape-forming factors.

c. Every geological feature consistently correlates with morphogenetic and orographic features. It is beyond doubt, that it is these so-called morpholithogenic elements that have been dominant in determining the main outlines of landscape subdivision in this country, where the plains, hills and mountains could be distinguished as macroregion types.

d. In delimiting certain landscape elements, physiographic factors, by interference, rather than morpholithogenic gave the best result in some cases. The interweaving of climatic, phyto- and pedogeographic effects were found to be very real distinguishing factors.

A good example is the physiographic delimitation of the Little Hungarian Plain. Geomorphologically, the Plain, as a morphoregion, extend well beyond the Rába river and locally almost up to the western boundary of the country (Fig. 4). Other physiographic factors, however, show that the alluvial fan plain of Sopron and Vas is not related in its pedologic, phytogeographic and climatic features to the Little Hungarian Plain, because the influence of the Alpine megaregion upon the adjacent plains is so intense that it affects the character of this region despite its morphological features. This is why the flat alluvial fan region in question was classified with the eastern foreland of the Alps along the western Hungarian border. On the basis of geomorphological evidence alone, this region is organically related to the alluvial fan of the Little Hungarian Plain.

A similar complex evaluation of physiographic elements was taken as the basis for subdividing and delimiting the Great Hungarian Plain. Contrary to the previous example, most of the landscape-forming factors of the Great Hungarian Plain penetrate across the right bank of the Danube into the wedgeshaped Mezőföld region, as far as Lake Balaton, although morphologically part of the Mezőföld is rolling country, and sharply delimited by the Danube. Its climate, steppe-like vegetation and soil have, however, justified its attachment to the Great Hungarian Plaine. Its separation from the Great Hungarian Plain is not absolutely justifiable on purely morphological grounds either, because most of the Mezöföld is also a loess- and sand-covered alluvial fan plain.

e. Landscape-typological research already carried out has shown that the use of rivers for delimiting natural landscape units is not very desirable, because in wide floodplain areas and on broad valley bottoms natural conditions are highly similar if not identical on both banks of the river. This is why in rolling and hilly regions we have regarded the main valleys as independent microregions, some of them being interregional in the sense of traversing several different regional types. They are usually attached to the higherorder region which includes most of their drainage area.

On both banks of the large rivers of the plains (the Tisza and the three Körös rivers) there are often mesoregions of similar nature, which have been united in the course of classification (the Upper, Middle and Lower Tisza region, etc.). Hence, in these cases, the river does not form an independent region or a regional boundary. These principles and methods have also been applied in delimiting and subdividing geomorphological regions, although geomorpho- 


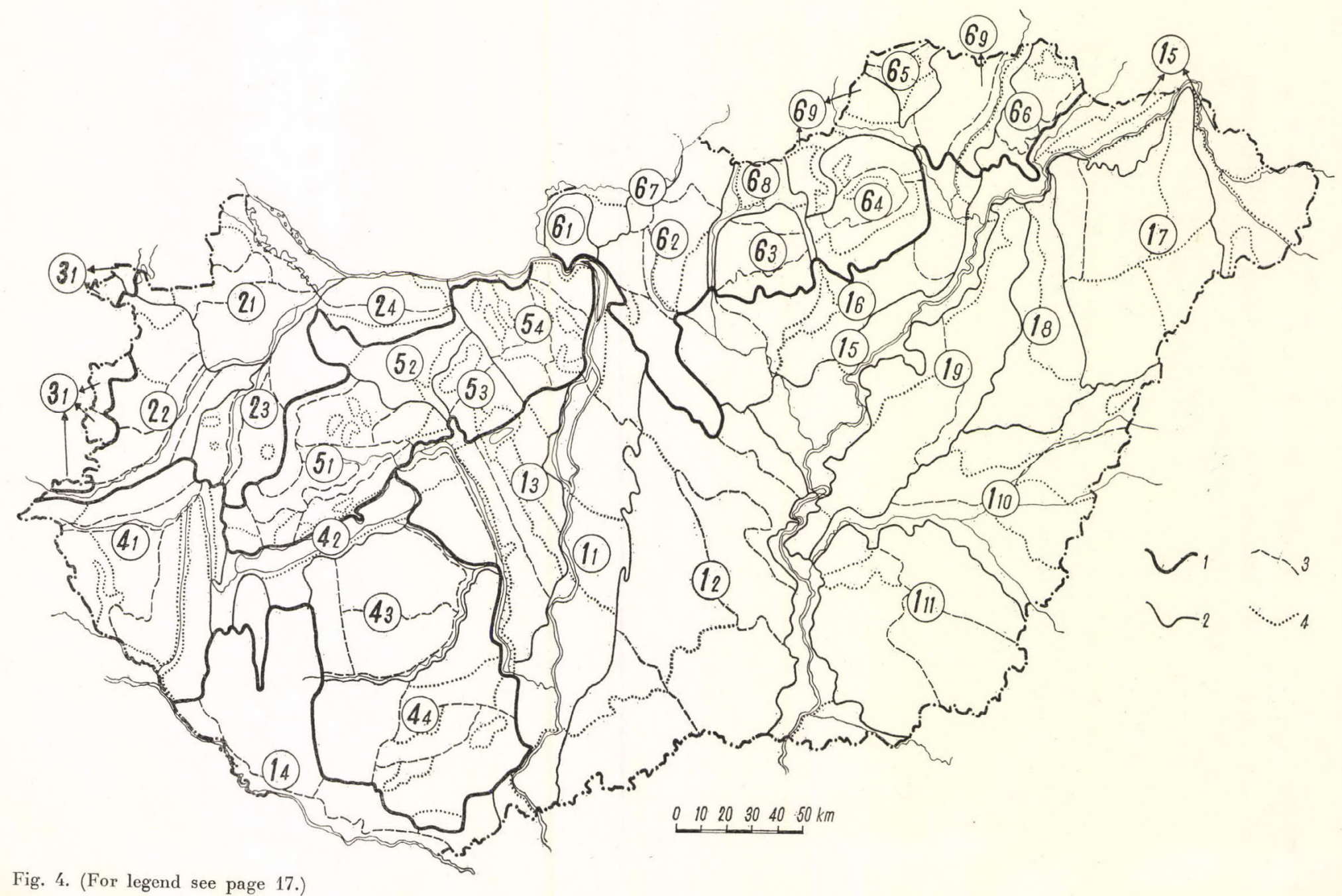


logically, the valleys, straths and floodplains on both banks of a river are even harder to distinguish.

In delimiting the boundaries of the Great Hungarian Plain where it abuts against the mountainous regions, the plant and soil cover and the individual assessment of phenological traits have sometimes given valuable help.

Even after applying our method of landscape subdivision based upon the complex evaluation of the natural agencies, there remain areas whose regional attachment is still problematical. This uncertainty resulted in most cases from the ambiguity of the evidence presented by the factors which were evaluated. In other cases, the boundaries between individual units may not be very sharp, because they are separated by border zones of transitional features, and also because some of our natural landscapes have been seriously wodified by human activity. ${ }^{3}$

It was not easy to eliminate the influence of traditional landscape names and units, although the vagueness of some landscape units, and their delimiting criteria does not mean that they do not objectively exist. In our opinion, the combination of our judgement and of the information available is still either insufficient or cannot be evaluated precisely enough for the purposes of landscape unit delimination in many areas. The judgement of the researcher may indeed be subjective even when dealing with an area of objective landscape units.

Fig. 4. Geomorphological regions of Hungary. Classification developed by M. Pécsi and S. Somogyi. Boundaries of some regions traced and their names introduced with co-operation of Z. Borsy, Gy. Lovász, S. Marosi, Z. Pinczés, A. Székely, and J. Szilárd.

1. The Great Hungarian Plain; 1.1. The Danube Riverine 1.2. Ridge of the Danube-Tisza Interfluve 1.3. The Mezőföld; 1.4. The Dráva and Inner Somogy Plain: 1.5. The Tisza Riverine; 1.6. Alluvial Plain of the Northern Great Plain; 1.7. The Nyírség; 1.8. The Hajdúság; 1.9. The Nagykunság and the Hortobágy Plain; 1.10. The Berettyó-Körös Riverine; 1.11. The Maros Alluvial

2. The Little Plain; 2.1. The Györ Basin; 2.2. The Sopron-Vas Alluvial; 2.3. The Marcal Basin; 2.4. The Gyôr-Esztergom Terraced Plain

3. The Subalpine Region; 3.1. The Sopron Mountains; 3.2. The Köszeg Mountains and the Vas Pediment

4. The Transdanubian Hill Region; 4.1. The Upper Vas-Zala Hill Country; 4.2. The Balaton Basin; 4.3. The Somogy Hill Country; 4.4. The Mecsek Mountains and the Tolna-Baranya Hills

5. The Transdanubian Central Mountains; 5.1. The Bakony Mountains; 5.2. The Bakony Mountains and the Piedmont Hills of the Vértes Mountains; 5.3. The Vértes and Velence Mountains; 5.4. The Dunazug Mountains.

6. The Inner Carpatian Central Mountains and Basin Chain; 6.1. The Börzsöny Mountains; 6.2. The Cserhát Mountains; 6.3. The Mátra Mountains; 6.4. The Bükk Mountains; 6.5. The North Borsod Karst Mountains; 6.6. The Tokaj-Zemplén Mountains; 6.7. The Middle Ipoly Basin; 6.8. Hills of the Zagyva-Tarna Interfluve; 6.9. The Sajó-Hernád Basin

$1=$ boundaries of morphomacroregions, $2=$ boundaries of morphomesoregions, $3=$ boundaries of morphosubregions, $4=$ boundaries of morphomicroregions

${ }^{3} \mathrm{~A}$ millennium of human activity has been transforming the natural environment into an increasingly artificial one, the sculpture and evolution of which is ever more modified by the anthropogenic factor. At present, moreover, society, with due respect for the laws of nature affecting landscape evolution, tends consciously to transform landscapes in order to better satisfy its own needs. 


\section{THE GEOMORPHOLOGICAL REGIONS OF HUNGARY}

As the synthesis of their physiographic research over several planning periods, Hungarian geomorphologists prepared a general geomorphological relief map of the country. Under the stimulus of this map and with the development of a new and comprehensive set of geomorphological symbols, $M$. Pécsi conceived the first overall geomorphological map of Hungary which was prepared at a scale of 1 to 500,0004. This map, providing a clear illustration of the traits and dynamic evolution of the relief of the country, proved particularly suitable for a more detailed subdivision of the country into geomorphological regions than could be achieved at the first attempt (Bulla 1962; Figs. 4, 5).

On the basis of the relief six geomorphological macroregions were distinguished:

1. the Great Hungarian Plain

2. the Little Hungarian Plain

3. Transdanubian hills

4. the Alpine foreland

5. the Transdanubian Mountains, and

6. the intra-Carpathian mountains and basins.

The sub-units within these macroregions were distinguished by a decimaltype numbering procedure. By this method and on the basis of the hierarchy of our geomorphological taxonomy, the relief units of Hungary can be fitted into the higher-order taxonomic units by a simple numerical nomenclature.

\section{THE PRINCIPLES OF GEOMORPHOLOGICAL SUBDIVISION}

When subdividing physiographic landscape units, the morpho-lithologic factor is often, but not always, found to be dominant among the landscapeforming agencies which together constitute the basis of any subdivision. In outlining geomorphological regions, we have taken as the basic starting point (a) the geostructural, (b) the morphogenetic, (c) the lithologic and (d) the orographic features of the regions. We consider these to be the elements of geomorphological landscape subdivision. As a complementary factor, we have taken into consideration the hydrological network, as, on the one hand, it affects and modifies and, on the other, as it itself is constantly being modelled by the above parameters. We have ignored climate and, through it, the direct influence of vegetation and soil, as their role in landscape sculpture and thus subdivision is reflected in the state and evolution of the relief.

In outlining individual geomorphological regions, we have evaluated singly and also in their totality the morpho-lithogenic elements as they bear upon the problem of delimitation. In a general way, the delimitation of a region

${ }^{4}$ Geomorphological map of Hungary. Ed.: Márton Pécsi. Editorial board: L. Ádám, Z. Borsy, E. Buczkó, L. Gazdag, L. Góczán, Gy. Hahn, M. Kaiser, S. Láng, S. Leél-Össy, Gy. Lovász, S. Marosi, M. Pécsi, Z. Pinczés, L. Rétvári, S. Somogyi, A. Székely, J. Szilárd. Published in Magyarország Nemzeti Atlasza (National Atlas of Hungary, 1967); scale 1 to 1,000,000 
was based upon the homogeneity or similarity of the elements, although not all elements are homogeneous within every region. In such cases, a hierarchy of elements was set up and the elements were evaluated accordingly. In delimiting a geomorphological region in a mountainous area, homogeneity of lithology could not be considered decisive: it was much more the identity of crustal structure and evolutionary history that was relied upon, which was supplemented by the evaluation of the relief type and of the drainage network.

These latter, so-called complementary, elements occasionally became paramount.

Paying due consideration to the commonly used morpho-lithogenetic elements, in the evaluation of the unique relief features of Hungarian landscapes it was sometimes necessary to take account of their spatial relationships. Accordingly, we locally united two or more geomorphological units of lower order even when of distinct structure and build, if they were related by proximity and common features of morphogenesis and geotectonic situation. Such subregions have been marked separately within the individual geomorphological regions. ${ }^{6}$

In this way the Mesozoic blocks of the Cserhát Mountains have been united into one geomorphological region and similarly with the volcanic Eastern Cserhát and the Gödöllö-Monor hills (6.2), the Triassic dolomite horst of the Vértes Mountains and the granite massif of the Velence Hills (5.3), the Palaeozoic granite massif, the Mesozoic fault blocks and the hills of unconsolidated Tertiary sediments in the Mecsek-Baranya region (4.4).

The typical case is, however, the identity or near-identity of morphology, crustal structure, morphogenesis and lithology within one and the same geomorphological region: e.g. the Mátra Mountains (6.3), the Börzsöny Mountains (6.1) and the Nyírség (1.7).

\section{TYPES OF GEOMORPHOLOGICAL REGIONS}

a. Three types of geomorphological region were distinguished with the mountainous areas:

1. Folded and block faulted, truncated mountains; among these, the Hungarian foreland of the crystalline core of the Alps constitute independent regions $(3.1,3.2)$.

2. Regions can be distinguished which consist predominantly of horsts and plateaus of Mesozoic age. These areas are largely block-faulted, partly imbricated and are complemented by subregions and microregions made up of both Palaeozoic crystalline blocks and young volcanics $(5.1,5.3,5.4,6.4$ and $6.5)$.

The accessory elements are in close structural and morphological connexion with those that are dominant. The Mecsek Mountains and the Baranya hills surrounded by hills of Tertiary age (4.4) are of similar type.

\footnotetext{
${ }^{6}$ Subregions are the first (or associate) taxonomic units within the geomorphological region.
} 
3 . The young Tertiary volcanic mountains constitute independent geomorphological regions within the Carpathian mountain range $(6.1,6.3,6.6)$. The smaller or isolated volcanic areas were, however, united with nearby mountains $(5.4,6.2)$ or hilly regions $(6.8)$ of different type. The latter were in such cases regarded as morphological subregions or microregions.

b. The hilly areas of Hungary, which are largely made up of unconsolidated Tertiary and Quaternary deposits, were subdivided into several separate regions $(4.1,4.3,4.4,5.2,6.9)$. As mentioned above, small Paleozoic and Mesozoic blocks have been incorporated into regions largely of hill character (4.4).

The mountainous areas almost invariably possess morphological subregions or microregions of rolling terrain, in the form of intramontane basins or dissected pediments in the forelands (e.g. 5.1, 6.3,6.4).

c. The geomorphological regions of the plains, which are known far and wide as the most characteristic landscape types of Hungary, were subdivided in three groups:

1. Floodplains and low alluvial-fan regions $(1.1,1.4$, in part also $1.5,1.9$, $1.10,1.11)$.

2. Alluvial-fan plains above the floodplain level and covered with fluvial deposits $(1.6,2.2,2.3,2.4)$.

3. Alluvial-fan divides covered with eolian deposits (1.2, 1.3, 1.7 and in part 1.4).

The regions of the third group may consist of subregions of similar origin and structure, but the surface of the entire region is made up of various unconsolidated deposits (e.g. alluvial fan bands alternately covered with windborne sand and loess).

The uniformity of geomorphological regions and the homogeneity of operative factors is typical first and foremost of the plains' regions and only to a smaller extent of the hill areas. However, even in the most homogeneous plain region there is no complete uniformity of all morpholithogenic elements. Such homogeneity can be found at best in microregions or if not only in morphofacies groups which are the lowest-order elements of geomorphological microregions and subregions.

d. Independent palley microregions or subregions were defined not only along the large rivers traversing the plains, i.e. the Danube and Tisza, but also in the valleys of medium-sized rivers in the mountains and hill regions $(2.2 .3,4.3 .4$, etc.). These are usually geomorphological units that are wedged between regions fundamentally different in nature $(1.4 .1,6.9 .3)$. The small valleys that do not attain the rank of independent region or subregion were evaluated as microregions or morphofacies groups within regions $(4.1,42$, $4.3 .44,6.8 .13,6.8 .14$, etc.). The taxonomic distinction of small valleys could be avoided in several cases owing to the small scale of our map; those that are shown are simply methodological illustrations. The morphological distinction of valleys is justified on the grounds of both principle and method and also from the economic point of view. 


\section{SPATIAL RELIEF UNITS AND A GENERAL GEOMORPHOLOGICAL HIERARCHY OF REGIONS}

Geomorphological literature has lacked any fundamental treatise of the principles and methods of geomorphological regionalisation, and no uniform scientific practice has been developed. For analogies, we can only turn to the subdivision, and hierarchy that has been developed for physiographic landscapes. In the above chapters we gave a brief outline of the criteria, principles and methods that were applied in the subdivision of relief, and in the delimiting of geomorphological regions. On the basis of these, we have set up the following taxonomic units and hierarchical system for the general subdivision of relief in Hungary.

\section{A. Morphofacies group}

In our classification, we have considered the morphofacies as the lowestorder homogeneous unit of relief in the geomorphological sense. A morphofacies is of homogeneous geological structure, and uniform morphogenesis and orography (e. g. strath, filled-up oxbow, pediment or valley slope element, top surface of an interfluvial ridge, alluvial fan of a creek, erosional gully on a slope, etc.). ${ }^{7}$

On the land surface, morphofacies appear in well-defined assemblages as a result of the unique combination in time and space of the relief-forming processes. It is from the assemblages of morphofacies groups that the lowest-order areal units (morphological microregions and subregions) of the geomorphological regions are composed.

B. The morpho-microregion and subregion

a. Morpho-microregions are obtained by unifying several morphofacies groups of identical genesis but which are heterogeneous in the orographic and lithologic sense. An example is the morphomicroregion of the Vác-Pest plain (1.1.11), which includes floodplain islands and closely related low terraces covered with wind-borne sand.

In areas of accumulation in the plains, interwoven and recurrent morphofacies of considerable areal extent had to be subdivided into morphological microregions purely on the basis of location (e.g. 1.1.21, 1.1.24); where they

7 There is a fundamental difference between morphofacies and ecological facies. The former is the fundamental physiographic unit of natural space (the relief), in the sense of physiotope, whereas the latter is a homogeneous and fundamental unit of the physiographic environment (ecotope) developed through the interaction of all landscape-forming factors (inorganic + biogenic + anthropogenic). A morphofacies, such as an oxbow lake, may contain several ecological facies, depending on the various stages of the infilling of its different parts. However, differences in ecclogical facies may be also due to anthropogenic influences on a morphologically homogeneous terrace or floodplain surface also, e.g. drained floodplain areas, and terrace surfaces covered with constructions. 
extended over various structural units, a separate morpho-subregion had to be assigned to each of these (e.g. 1.5.1, 1.5.2, 1.5.3).

b. The category of morpho-subregion was established for morphofacies groups of identical geomorphological type, related by their history of evolution, but standing more or less apart structurally, spatially or orographically from their surroundings.

The alluvial fans of medium-size rivers on the plains' margin were defined as geomorphological microregions, some of which were, however, united into subregions. The alluvial-fan surfaces of the large rivers crossing the plains were subdivided according to their morphological types and orographic position into subregions and microregions $(1.2,1.10)$.

In the mountainous and hill regions it is the broader valleys, small basins, and interfluvial ridges (e.g. Zalaapáti divide, 4.2.43, the lower Zala valley, 4.1.44, and the North Bakony basins, 5.1.61) that constitute morphomicroregions. On the other hand, dissected pediments of considerable areal extent, or structurally related fault blocks constitute separate morpho-subregions (e.g. the volcanic mass of the Mátra Mountains, 6.3.1, the Mátraalja pediment 6.3.2, the Southern Bakony, 5.1.4, the Northern Bakony 5.1.6, and the pediment of the North western Bakony, 5.1.7).

C. The geomorphological mesoregion (morpho-mesoregion)

Morpho-mesoregions are the distinct and separate fundamental relief units of the main morphological types, (plains, mountains). Their delimitation is based upon hydrology, orographic features and the characteristics of their evolutionary history and structure. The mesoregions of the plains may be composed of almost homogeneous morphomicroregions or morphofacies groups such as the plains along the Danube, 1.1, and along the Tisza, 1.5, whereas the mesoregions of the mountain and hill regions are usually synthetic units composed of related or heterogeneous sub- and microregions and stand apart from the adjacent mesoregions (Bakony 5.1, Mátra 6.3, etc.).

D. The geomorphological macroregion (morpho-macroregion)

The geomorphological macroregion is a structural and morphological unit on a regional scale, the constitution and evolution of whose relief has been homogeneous for some considerable time. Hence, a macroregion is a complex of morphogenetically similar mesoregions.

On these grounds, the following macroregions are delimited in Hungary: (1) the Great Hungarian Plain, (2) the Little Hungarian Plain, (3) the Alpine foreland, (4) the Transdanubian hill, (5) the Transdanubian Mountains, (6) the intra-Carpathian mountains. 


\section{E. Geomorphological systems (and macro-, mega-morphoareas)}

Hungary is situated in the Carpathian or Pannonian Basin encircled by the Carpathians, Alps and Dinarids, all elements of the young fold mountain chain of the Eurasian system. The latter is one of the most fundamental morphostructural units of the terrestrial surface, and from the hierarchy viewpoint, the largest taxonomic units, of the relief are the large morphogenetic systems (the Eurasian, Circumpacific, Caledonian, Variscan mountain systems, ancient massifs and stable and mobile shelves).

Features second in size to these large subcontinent units are called morphomacroareas, e.g. the Carpathians, Dinarids, and Carpathian Basin, while the structural ensemblages of such units e.g. the Central European portion of the Eurasian mountain system, can be regarded as morpho-megaareas.

The geomorphological subdivision of relief need not necessarily be the schematic linear hierarchy outlined in the above sequence. It may happen that a morpho-mesoregion is directly composed of facies groups or morphomesoregion is directly composed of facies groups or morpho-microregions, without the intercalation of a subregion. A similar situation may also prevail in the delimitation and subdivision of the higher taxonomic units.

It is a matter of course that every generalized hierarchical subdivision of the relief will emphasize the general or common traits and not the unique and special traits and phenomena.

This is why, coupled with the small scale of the map, we have tried to avoid establishing too many orders and only have used sufficient categories-taxonomic units - as seemed indispensable on the basis of the available geomorphological evidence. These are

1. the morpho-microregion

2. the morpho-subregion

3. the morphological region

4. the morpho-macroregion

5 . the morpho-macroarea and megaarea

6. geomorphological system the terraced Vác-Pest plain

the Pest plain

the Danube plain

the Great Hungarian Plain

the Carpathian Basins

and Alpine-Carpathian-Dinaric

system

the Eurasian mountain chain

\section{REFERENCES}

Berg, L. S. (1950): A földrajzi tájak (Geographical landscapes). Földrajzi Könyø-és Térképtár Ért. Vol. 1.

Bobek, H. and Schmithüsen, J. (1949): Die Landschaft im logischen System der Geographie. Erdkunde, 3, 2/3.

Bulla, B. (1962): Magyarország természeti tájai (The natural landscapes of Hungary). Földr. Közl. 86.

(Tsys, Р. N.) Цысь, П. Н. (1961): Некоторые вопросы методики ландщафтных исследований горных стран. (On the methodology of landscape research in mountains). Геогр: сб̄op. №6 Львов. 
Физико-географическое районирование нечерноземного центра (1963). Под редакцией Н. А. Гвоздецкого и В.К. Жучковой (Physico-geographical regionalization of the nonchernozem centre). Изд-во Московского Университета.

(Isachenko, A. G.) Исаченко, А. Г. (1965): Основы ландшафтоведения и физико-географическое районирование. (Principles of the research for physical landscape and physicogeographical regionalization.) Изд-во «Высшая школа», Москва.

Kádár, L. (1941): A magyar nép tájszemlélete és Magyarország tájnevei (Landscape notions in the thought of the Hungarian people and Hungarian landscape names). Országos Táj-és Népkutató Intézet, Budapest.

Kondracki, J. (1964): The problem of the taxonomy of natural units in regional geography. Geographia Polonica, 2.

Kondracki, J. (1965): W sprawie fizycznogeograficznego podzialu Europy w klasyfikacji dziesietnej. Przegl. Geogr. XXXVII, 3. Warsawa.

Kondracki, J. (1966): Das Problem der Taxonomie der naturräumlichen Einheiten. Wissenschaftliche Veröffentlichungen des DIFL, Neue Folge 23/24.

Marosi, S. and Szilárd, J. (1963): A természeti földrajzi tájértékelés elvi-módszertani kérdéseirôl ( $\mathrm{On}$ the principles and methods of physiographic landscape evaluation). Földr. Ért. 12.

Mendöl, T. (1932): Táj és ember (Landscape and man). M. Sz. Kincsestára 46.

Mihailov, V. A. (1964): A tájkutatás és a természeti földrajzi tájfelosztás DélnyugatUkrajna és Magyarország szomszédos területeinek példáján (Landscape research and physiographic landscape subdivision exemplified by the juxtaposed regions of SW Ukraine and Hungary). Földr. Közl. 12.

Meynen, E. and Schmithüsen, J. (1953): Handbuch der naturräumlichen Gliederung Deutschlands, Remagen.

Neef, E. (1961): Landschaftsökologische Untersuchungen als Grundlage standortsgerechter Landnutzung. Die Naturwissenschaften, 48.

Neef, E. (1963): Topologische und chronologische Arbeitsweisen in der Landschaftsforschung. Petermanns Geogr. Mitteilungen, 107.

Pécsi, M. and Sárfalvi, B. (1960): Magyarország földrajza (The Geography of Hungary). Budapest; Akadémiai Kiadó.

Prinz, Gy. (1936): Magyarország tájrajza (A description of the landscapes of Hungary). Magyar földrajz I. Bp.

Schmithüsen, J.: (1948): "Fliesengefüge der Landschaft" und "Ökotop". Berichte zur deutschen Landeskunde, 5.

Schmithüsen, J. (1963): Was ist eine Landschaft? Erdkundliches Wissen, Schriftenreihe für Forschung und Praxis 9. Wiesbaden.

(Solntsev, N. А.) Солнцев, Н. А. (1962): Основные проблемы советского ландшафтоведения. (The main problems of Soviet landscape science). Изд ВГО т. 94 вып. 1.

(Solntsev, N. А.) Солнцев, Н. А. (1962): (ред.) и др. Морфологическая структура географического ландшафта. (Morphological structure of the geographical landscape.) М. Изд. МГУ Москва.

Teleki, P. (1937): A tájfogalom jelentöségéröl (On the importance of the landscape concept). Budapesti Szemle.

Wagner, R. (1953): A táj és légkör (Landscape and atmosphere). Időjárás, Vol. 49.

Wagner, R. (1956): A táj fogalma (The concept of landscape). Földr. Közl. 80. 
EXOGENOUS PROCESSESOF THE TERRESTRIAL SURFACH

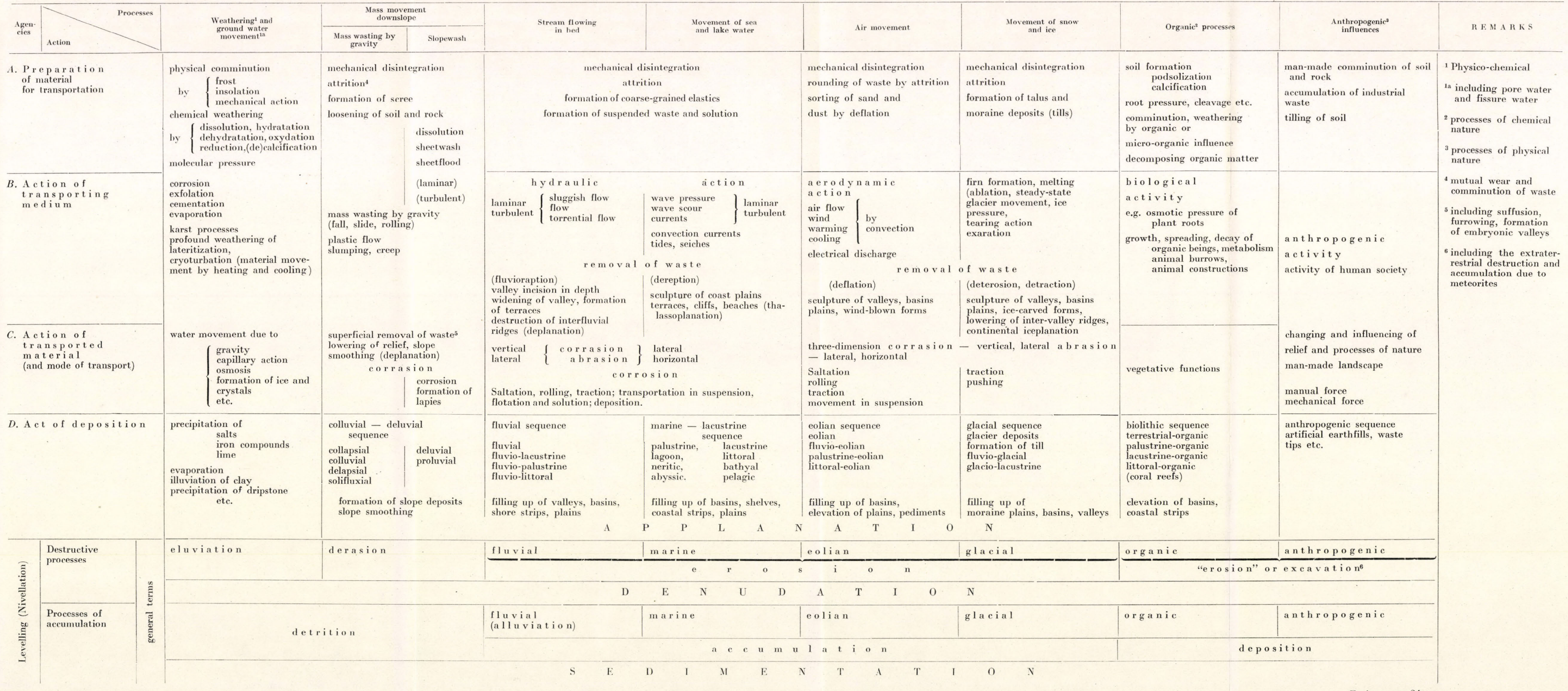





\section{GROUND-WATER AQUIFERS AND PRESSURE DISTRIBUTION}

by

L. S I M O N

\section{THE IMPORTANCE OF PLEISTOCENE DEPOSITS FOR WATER SUPPLY}

1. The most important source of drinking water in the Great Hungarian Plain is the water stored in the coarse Pleistocene fluvial deposits. In the areas some distance from the rivers, it is from these that the industrial and agricultural water requirements are satisfied, as well as a small percentage of the water needed for our rapidly developing irrigation systems. The Pleistocene deposits of the Great Plain are tapped by more than 20,000 drilled wells. In the towns and in the industrial plants of some importance, there are waterworks for the purification and distribution of water.

The ground-water resources are considerable and of the most important ones in Europe. The Great Plain as a geomorphological macroregion has an area of some $100,000 \mathrm{sq}$. $\mathrm{km}$, roughly half of which is in Hungarian territory. The thickness of the Pleistocene deposits is highly variable from one placeto another, ranging, together with the thin recent deposits from 10 to $600 \mathrm{~m}$. The mean thickness is roughly $200 \mathrm{~m}$, about 30 percent of which is coarse fluvial sand and gravel. The water stored in these coarse-grained deposits alone amounts to $4,000 \mathrm{cu} . \mathrm{km}$ on the assumption of 20 percent permeable pore volume. This is equal to eighty lakes of the same areal extent as Lake Geneva and $100 \mathrm{~m}$ deep. More than half of this water resource is situated under Hungarian soil.

The water in the Pleistocene deposits of the Great Plain is classified as fresh water with 200 to $400 \mathrm{mg}$ per litre dry residue: its mean iron content is 0.2 to $1.5 \mathrm{mg}$ per litre, its chloride content 5 to $15 \mathrm{mg}$ per litre and its hardness 10 to 20 German degrees. Its chemical composition is primarily hydrocarbonatic.

The temperature of the water in the Pleistocene deposits of the Great Plain reflects the high geothermal gradient $-1{ }^{\circ} \mathrm{C}$ for every 15 to 22 meters-of this region. The mean depth of the large-output wells of the big waterworks is roughly $200 \mathrm{~m}$, which usually produce water of between 18 and $22^{\circ} \mathrm{C}$ at the surface. The shallow wells (10 to $30 \mathrm{~m}$ deep) yield water of 9 to $12{ }^{\circ} \mathrm{C}$ temperature, which is immediately suitable for the cool storage of fruit or for the non-frozen products of the canning industry, etc.

2. Of the water resources stored in the Pleistocene deposits, the water in the coarse deposits of the Lower Pleistocene is of particular interest.

Let us point out to begin with that the term "Lower Pleistocene" does not invariably denote a well-defined geological age group, but sometimes only the relative position of beds in the geological succession. It is used to denote the deposits which are mostly coarse-grained overlying the Upper Pannonian or the isolated rags of Levantine age. Several workers have placed the lower boundary of the Pleistocene at the junction of the fine-grained marine and 
lacustrine deposits and the overlying fluvial sands and gravels (Pécsi, Urbancsek). The age of these deposits may not be Lower Pleistocene, in the rigorous sense everywhere, and it is therefore preferable to call them Early rather than Lower Pleistocene.

The particular importance of these deposits as an aquifer resides, first of all, in the fact that they are of coarser grain size than the overlying permeable deposits. The gradual refinement of the Pleistocene deposits from the bottom upwards is a general rule with very few exceptions. It was only at the end of the Pleistocene and during the early Holocene that another episode of rapid subsidence, particularly on the margins of the Great Plain, entailed the formation of alluvial fans consisting largely of gravel and coarse sand.

The coarseness of the Early Pleistocene deposits permits the sinking of high-yield wells which produce water at low cost. At the same time, water from such wells is medically sterile being practically free of bacteria, and is hence a first-rate drinking water. Another important feature is that most wells sunk into the Early Pleistocene over almost all the Great Plain produce water that flows freely to the surface, thus generating a substantial saving in pumping cost for municipal authorities as well as for the private well owner. In the case of the large waterworks this is not so much of an advantage, however, as they use pumps anyway to produce and distribute water even if their wells are "positive" (artesian). (There are, however, exceptional cases where it is the aquifer pressure that distributes water over a widespread consumer network). In connexion with these important practical features we should point out at this juncture that in the so-called "negative" areas the piezometric surface of the water in the Early Pleistocene deposits is lower than that of the aquifers overlying them. The present author regards the upper boundary of the Early Pleistocene as that depth or deposit which yields water flowing freely to the surface in areas of positive pressure and, in areas of negative pressure, that depth at which the piezometric surface exhibits a sudden drop. Hence, as used in the present paper, the term Early Pleistocene denotes a hydrostatic and hydrodynamic rather than a purely geological concept.

\section{WATER PRESSURE, PRESSURE STATE AND THEIR SIGNIFICANCE}

3. Water pressure is expressed in a relative sense and in practice most usually in terms of the altitude of the static water table relative to the ground surface or to sea level in metres and centimetres. In the absolute sense, however, pressure is measured at the point of outflow on the surface and is expressed in $\mathrm{kg}$ per sq. $\mathrm{cm}$ or as the height of the water column in metres. As the main purpose of the present paper is a regional comparison, the profiles and map were designed on the basis of pressure measured by the height of the static water table relative to sea level, although the altitude of the static water table relative to the ground surface is also indicated. The water table at a certain well is called "positive" if it is above the ground surface (i.e. if the well is artesian), and "negative" if the water table is below the ground surface. An "area of positive pressure state" is an area where pressure increases 
relatively with depth below the surface in such a fashion that below a certain depth the pressure is positive, whereas in an "area of negative pressure state" the rate of pressure increase with depth is such that deeper aquifers have lower static water tables. (Naturally, absolute pressure also increases with depth in these areas.) A "hydrostatic pressure state" characterizes a succession of aquifers where the rate of pressure increases with depth is such that the static water tables of all aquifers coincide, whether below or above the ground surface.

Ground-water pressure has, besides its obvious practical importance, it being one component of well yield, and a criterion for a successful pumping technology, etc., the added interest of being one of the most reliable indicators of the vertical and horizontal relationships between subsurface aquifers. It is more reliable than chemical composition, e.g. iron content, hardness, and Cl ion concentration, because hydrostatically and hydrodynamically isolated aquifers may contain water of similar composition if in prolonged contact with the same type of sediment; moreover, along fault lines, salt water may surge from deep aquifers and result in local changes of composition within one and the same aquifer. Hence, the investigation of ground-water pressure is by no means an academic branch of hydrogeology; indeed, it is one of profound practical significance, yielding reliable information about subsurface water resources, their inter-connections, flow directions, stagnation, and recharge etc.

The pressure distribution of ground water has been, in the past few years, one of the main focuses of interest for Hungarian research workers, from both its hydrogeological and various hydraulical aspects. Besides "Magyarország vízföldtani atlasza" (The Hydrogeological Atlas of Hungary) and its explanatory volume by E. R. Schmidt and E. Almássy, which are both highly appreciated internationally, comprehensive papers on the subject have been published by A. Rónai, J. Urbancsek and the present author.

\section{HORIZONTAL AND VERTICAL PRESSURE COMPENSATION}

4. The views expressed below diverge from those put forward in The Hydrogeological Atlas of Hungary. The method adopted in the Atlas consisted of connecting with so-called isopotential lines the tapping points of wells (in effect, depth intervals provided with filters reduced to points) which gave identical static water levels relative to sea level. According to E. Almássy, one of the editors of the Atlas, pressure-compensating flow takes place along these isopotential lines. He stated that such flow is possible between points as far apart as 50 or $60 \mathrm{~km}$ and with height differences of up to $400 \mathrm{~m}$. Compensating flow can take place either directly (the permeability of the clayey and silty deposits intercalated between the aquifers is sufficient in Almássy's opinion to permit pressure compensation), or indirectly, making use of the lenticular deposition of most of the Pleistocene sediments, which permits the outflanking of impermeable lenses. Even if theoretically such pressure compensation is possible, although its effectiveness over large dis- 
tances is highly unlikely, the examples given in the Atlas and in the subsequent paper by Urbancsek (1963a) raise doubts about its feasibility.

The phenomenon of the "limit gradient" makes clays and silty clays practically impermeable at depths below 30 to $50 \mathrm{~m}$, so that water in them is stationary. Incidentally, Almássy himself made use in a later paper of the formula proposed by J. Juhász for the limit gradient:

$$
\mathrm{I}_{0}=\frac{5 \cdot 64 \times 10^{-11}}{\mathrm{n}^{4} \mathrm{r}_{0}} \operatorname{Pr},
$$

where $\mathrm{n}$ is the porosity in decimal fractions of unity,

$\mathrm{r}$ is the predominant grain size in $\mathrm{cm}$,

$\mathrm{Pr}$ is absolute pressure in metres of a water column.

The critical gradient at which water in the pores of the sediment is completely stationary varies with the pressure $\operatorname{Pr}$ : moreover, the finer-grained the sediment, the higher is the pressure gradient that produces no seepage. For $\mathrm{I}=1$, seepage only stops at 100 to $150 \mathrm{~m}$ depth and in fairly consolidated clays at that. But for $I=0.1$ it stops in fine clays even at a depth of 15 to $20 \mathrm{~m}$. Where pressure gradients are as low as in the Pleistocene deposits $(I=0.01)$, there is no seepage in compacted silt 100 to $150 \mathrm{~m}$ below the surface and even in fine sands, there is seepage at 200 to $300 \mathrm{~m}$ depth only if they are loosely compacted.

The lithology of the Pleistocene of the Great Plain is such that between the various "compartments" in the sequence, pressure compensation over distances of some kilometres is possible only in exceptional cases. Even vertical compensation between the various aquifers below a given point on the ground surface is somewhat doubtful.

An investigation of vertical pressure compensation is most likely to yield results in areas where wells are close-spaced, are of various depths, and tap aquifers producing different quantities of water, i.e. in towns. In some of these areas, the static level in the wells sunk into the most intensely exploited aquifer (which in the Great Plain is most usually the lowermost aquifer of the Pleistocene) has been gradually falling for some time. Reasons for this may be exploitation in excess of recharge, or that the drawdown cones of adjacent wells gradually merge to form over areas a few kilometres across what I. Orlóci and his co-workers have termed a "dynamic rest level", which, although reversible in principle, is continually sinking nevertheless. If local radial communication exists between the individual "water stages", then the static levels in the aquifers above that most intensely exploited reflect its trend, i.e. to sink as the "dynamic rest level" sinks.

We have investigated this point by two methods; firstly, by plotting profiles, and secondly, by a statistical method. We have plotted ground-water profiles relative to sea level for wells of various depth, which have been grouped by age, measured in 10 to 30 year intervals, for the towns of Debrecen and Kecskemét, where the static level in the wells of the waterworks is known to be sinking. Water levels have been plotted against time for the towns of Szeged, Szentes and Nyíregyháza, where no such sinking occurs, to check the previous method (Figs. 1 and 2). The profiles reveal with remarkable clarity, 
particularly in the Debrecen case, that whereas the static level is sinking steadily in all well groups that tap the Early Pleistocene, that of wells sunk into aquifers higher up is just as near the surface as it was in the late 19th or early 20th century. At Kecskemét, even the relatively shallow wells shown in the profile are tapping the Early Pleistocene, and as with the deeper wells, decrease in pressure occurs in these as well.

The statistical analysis of several hundred wells in Debrecen gave the following results:

Early Pleistocene: static water levels up to 1910: - 4.8 m; from 1911 to 1945: $-10.8 \mathrm{~m}$; from 1946 to 1955 : $-14 \cdot 3 \mathrm{~m}$; from 1955 to 1962 : $-16 \cdot 3 \mathrm{~m}$.

Middle Pleistocene: up to 1945: $-4.8 \mathrm{~m}$; from 1946 to 1955 : $-4 \cdot 3 \mathrm{~m}$; from 1956 to 1962 : $-4 \cdot 3 \mathrm{~m}$ (wells 60 to $90 \mathrm{~m}$ depth).

Late Pleistocene: up to 1910 : $-4.8 \mathrm{~m}$; from 1911 to $1930:-4.1 \mathrm{~m}$; from 1931 to 1945 : $-4 \cdot 1 \mathrm{~m}$; from 1946 to 1955 : $-3 \cdot 7 \mathrm{~m}$; from 1956 to $1962:-3 \cdot 4$ $\mathrm{m}$ (well depth 20 to $60 \mathrm{~m}$ ).

All in all, despite a depression of almost $12 \mathrm{~m}$ in the Early Pleistocene aquifers, the pressure in those of Middle Pleistocene age did not decrease. Hence, 8 to 12 metres of impermeable layers or lenses can effectively prevent pressure compensation, even within this relatively small area.

In consequence, if there is no pressure-compensation between aquifers in the same locality, we should drop a fortiori the idea of such compensation between non-identical aquifers at a considerable distance from each other. Compensation between aquifers at different depths is possible, but this is a different problem, as in the case of coarse deposits covering a considerable area, without being divided into "compartments" by impermeable layers. Such is the situation in the upper layers of thick and extensive alluvial fans where most of the deposits consist of gravel and coarse sand, interspersed at most only with lenses of impermeable sediment. But in the case of hydrogeological units of the size of the Great Plain we cannot base a hypothesis of pressure compensation and resulting seepage upon the ideas put forward in The Hydrogeological Atlas of Hungary. We require instead a method which does not disregard the geological history, but which uses it as a foundation.

\section{METHOD PROPOSED BY THE AUTHOR}

5. The essence of the author's method is the separate treatment of the static levels in the various hydrogeological "compartments" which can be sufficiently well delimited on the basis of aquifer grain size and on the thickness of impermeable clayey layers separating these compartments. Having es tablished the static levels relative to both the sea level and the ground surfa ce, I have separately connected the plots of individual aquifers. The curves thus obtained may be called pressure or potential surfaces. The plots of E arly Pleistocene aquifers, where pressure compensation could be taken for g ranted on the basis of such evidence as geology, were connected with a bold line, and similarly with the plots of Middle and Upper Pleistocene aquifers, a lthough these by no means indicate pressure compensation: on the contrary, 
their hugging of the relief proves that they are the result of various sets of local pressures without any lateral compensation. The isopotential curves have been interrupted wherever there is a sharp break in the plot and, where a fault line can be assumed. Making use of A. Rónai's ground-water map, the ground-water level has also been approximately plotted on the profiles. As the author's own research is centred upon the sandy areas of the Great Plain, the pressure distribution of the Nyírség and of the sandy divide between the Danube and the Tisza has been examined in the greatest detail in the present study. Accordingly, 15 profiles were constructed across the Nyírség and its marginal depressions in the northeastern part of the Great Plain, 7 across the aforementioned divide and 2 across the entire Great Plain itself. In the following, however, only those profiles necessary to demonstrate the fundamental relationships and regularities will be analysed. On the basis of the profile data, it was possible to construct a static-level map with reference to sea level for the Early Pleistocene deposits of the entire Great Plain. This map is restricted to the Early Pleistocene because it is only this "compartment" that produces levels more or less connected horizontally over the entire Plain. It is not worth while to prepare a similar map for the higher Pleistocene compartments, because the water levels of these simply paralle] the surface with local differences of but a few metres.

In order to illustrate the geological and hydrogeological unity of the Farly Pleistocene in the Nyírség and in the Szatmár Plain, a combined sketch profile has also been constructed (Fig. 5). The borehole profiles and geophysical logs prove the continuity of the Early Pleistocene complex over the entire region. A deep Early Pleistocene depression in the middle of the Nyírség around Nyírbátor and Nyírlugos is hypothesized. The almost exactly horizontal-i.e. pressure-compensated-static level proves that the Early Pleistocene of the Nyírség and of the Ecsed Swamp depression is an aquifer forming a single hydrostatic and hydrodynamic entity.

A detailed analysis of the profiles will not be presented here, since it has already been published in Hungarian in the journal Földrajzi Értesítô (1966, No. 3) and the discussion will be restricted to these conclusions of general interest.

\section{HYDROGEOLOGICAL AND HYDRAULICAL CONCLUSIONS AND INTERPRETATIONS}

6. The main conclusions to be drawn from the analysis are as follows.

a. Even within the Pleistocene, water contained in the unconsolidated deposits of the Great Plain is subdivided into well-defined hydrogeological stages. Vertical communication, resulting in pressure compensation between the stages, is exceptional and restricted, as indicated above, to depressions filled with large masses of coarse sediment on the one hand, e.g. those around Polgár and Kiskőrös, and to the upper parts of alluvial fans on the other, e.g. the Rétköz and the margin of the Nyírség. On the basis of the chemical composition of the water, hardly any vertical zoning could be established within the Early Pleistocene. However, the pressure distribution undeniably confirms 
the hypotheses concerning such a zoning. The Pleistocene is indeed zoned, not only from the hydraulic viewpoint. This zonation is due to the same structural and paleoclimatic causes as the geological succession. The present-day hydrogeological zonation, however, is not entirely contemporaneous with the formation of these deposits, but is also affected to some extent by the subsequent structural evolution.

b. In the shallow deposits, lateral communication over distances of the order of ten kilometres is restricted to the depressions and alluvial fans mentioned above.

We should point out here that the lack of pressure compensation so obvious in the profiles, is not a direct consequence of the cited formula for the limit gradient. The static levels of shallow wells (30 to $100 \mathrm{~m}$ ) exhibit differences of 15 to $30 \mathrm{~m}$ even over relatively small distances, whereas the critical values from the limit-gradient formula applied to a depth of $100 \mathrm{~m}$ and a mean pore volume of 40 per cent $(n=0.4)$, are for a sand of 0.5 to $0.2 \mathrm{~mm}$ grain size, 5.4 to $13.5 \mathrm{~mm}(!)$, for a fine sand of 0.2 to $0.1 \mathrm{~mm}$ grain size, 14 to $17 \mathrm{~mm}$ and for a fine sand of 0.1 to $0.05 \mathrm{~mm}$ grain size 27 to $54 \mathrm{~mm}$. Hence, in the deposits of sand typical of the Late and Middle Pleistocene, a few centimetres of pressure difference are sufficient to start pressure-compensating flows.

It follows from the above that the limit gradient can be responsible for a lack of pressure compensation only if the geometry of the deposits is predominantly lenticular, with the sand forming lenses in a mainly clay and clayey matrix, because in clayey sediment the limit gradient can be up to $15 \mathrm{~m}$ (!) even at a depth of $100 \mathrm{~m}$. This order of magnitude yields a sufficient explanation for the observed pressure differences over distances of 2 to 5 kilometres. Now if this lenticular deposition is indeed the reason why the static levels of Late and Middle Pleistocene aquifers exhibit substantial absolute variations although always staying close to the surface, then we must draw certain logical conclusions, which are of practical importance:

b1. If the static levels are invariably close to the surface and the pressure is not modified by gas in the water, which is the general rule, with the single exception of the aquifer at Püspökladány, then pressure is due to gravity acting upon both the solid material overlying the aquifer, and material contained in the aquifer. Hence, the aquifer essentially possesses a compaction-type regime.

b2. In such an aquifer, lateral recharge is out of question, and exploitation is restricted to the static reserve, except for some slight recharge from the over- and underlying clayey and particularly silty layers.

b3. The recoverable water reserve is restricted and determined and can be computed from Juhász' formula. Still, the reserves that can be exploited from compaction-type aquifers under the actual hydrogeological conditions of the Middle and Late Pleistocene in the Great Plain are quite substantial. The present author has computed 1.2 million cu. $\mathrm{m}$ per sq. $\mathrm{km}$ for a drawdown of $10 \mathrm{~m}$ for the Middle and Late Pleistocene deposits around Debrecen, where the time series of several hundred wells permitted a fairly accurate calculation.

c. Contrary to the above, the deposits of the Early Pleistocene-irrespective of their precise geological age and, apart from a few exceptions, of their depth 
below the surface-,generally permit a lateral pressure-compensating flow of the water contained in them. Pressure compensation is possible over distances up to and greater than $100 \mathrm{~km}$. The assumption that a very slow pressure compensation should take place over the entire Great Plain is by no means unjustified. Whereas the altitudinal range of the surface in the Great Plain is more than $100 \mathrm{~m}$, and that at the bare of the Early Pleistocene more than $500 \mathrm{~m}$, the overall range of the static levels of all Early Pannonian aquifers hardly amounts to $35 \mathrm{~m}$-disregarding a few uplifted blocks, some of which are not even covered with Pleistocene deposits. In this succession of strata, the limit gradient cannot prevent seepage. The Early Pleistocene deposits of the Great Plain largely consist of gravel, and coarse- and medium-grained sand. The percentage of fine sand of 0.1 to $0.2 \mathrm{~mm}$ in diameter is small, and that of 0.05 to $0.1 \mathrm{~mm}$ grain size negligible. But even in the latter, at a mean depth of 200 to $300 \mathrm{~m}$ in the Early Pleistocene deposits, the limit pressure is but 6 to $15 \mathrm{~cm}$. If there is no other obstacle to pressure compensation, the limit gradient will certainly not prevent it. Hence, the Lower Pleistocene aquifers possess a gravity-type regime, in which water flows owing to the potential differences within the aquifer towards the points of discharge. Thus the direct action of the gravity field upon the water is not hampered in any way.

d. The terms "positive" and "negative pressure state" can be given a more rigorous interpretation. The common feature of both the negative and the positive pressure state is that the shallow aquifers are under local pressure, whereas the deeper (Early Pleistocene) ones are under pressure transmitted from remote areas or, more precisely, are in equilibrium with the pressures at remote areas. In the areas of higher relief, the static level of the deep aquifers is deeper than that of the shallow ones: hence, the pressure state is negative. Classic examples from the profiles include the localities of Nyírbátor and Mátészalka in the Nyírség and Pusztavacs and Csemő and Kecskemét on the divide between the Danube and Tisza. The positive pressure state, in which the static levels of the deeper aquifers are higher (in most cases to the extent of yielding artesian water from the Early Pleistocene deposits) is due to a fully analogous mechanism. The shallow aquifers have static levels close to, but invariably below, the ground surface, whereas the static level of the deeper aquifers, which is in equilibrium with more remote and elevated areas, is higher than that of the local aquifers, i. e. is positive. Examples of this type are pairs of localities where the positive and negative pressure states remain in equilibrium: e.g. Mátészalka vs. Nagyecsed and Kecskemét vs. Kiskunfélegyháza. Finally, the so-called hydrostatic pressure state develops where the entire succession of strata essentially consists of coarse permeable sediments, with at most a few intercalated lenses of clay and silt. In these areas, pressure compensation is possible even in the vertical sense, so that wells drilled to various depths will have essentially identical static water levels.

e. In studies of pressure distribution, authors usually refer to the geological structure, but they often let it pass by merely citing references and without attempting to analyse the problem. The role of geological structure in affecting pressure distribution is an indirect one. The elevated portions of the plain -where negative pressure states prevail-generally overlie the buried hills 

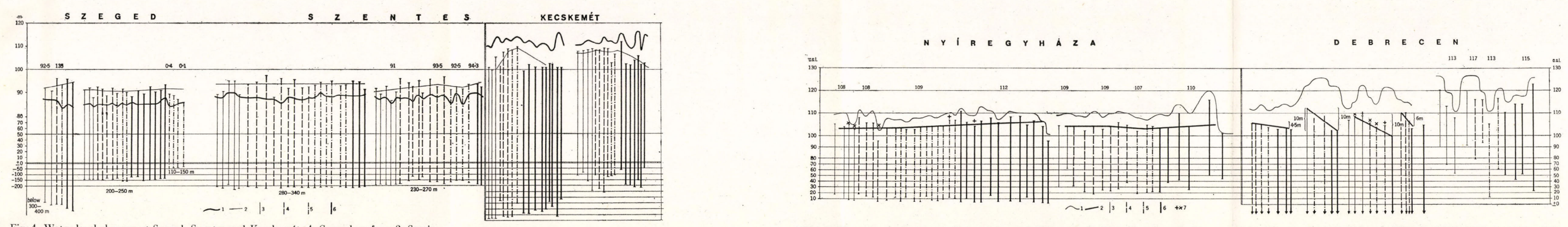

Fig. 1. Water level changes at Segeged, Szentes and Keeskemét. 1. Ground surface. 2. Static
water level. 3. Prior to $1910.4 .1910-1940.5$. $1941-1955.6 .1956-1963$

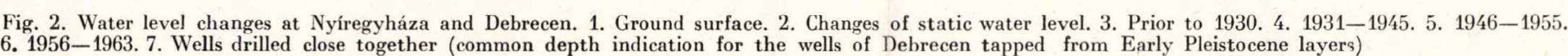

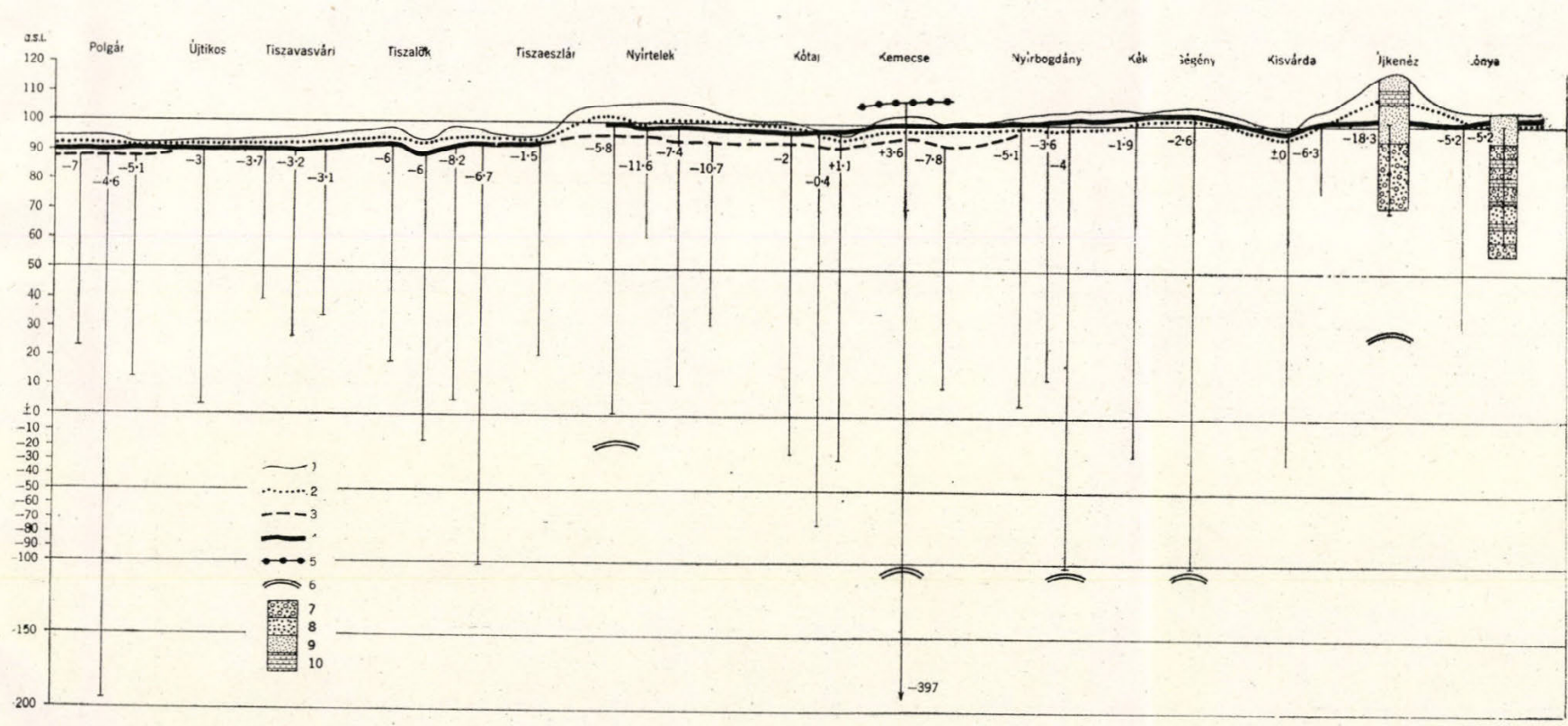

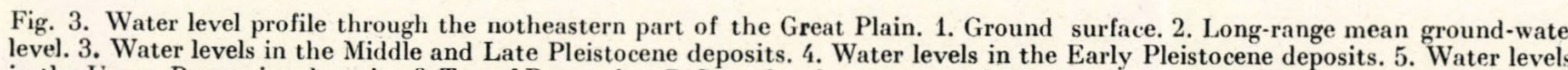

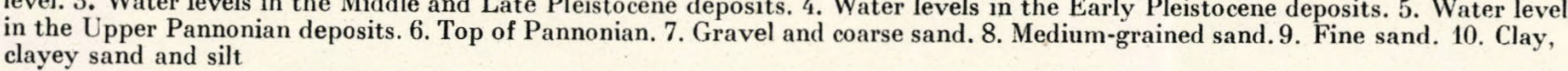

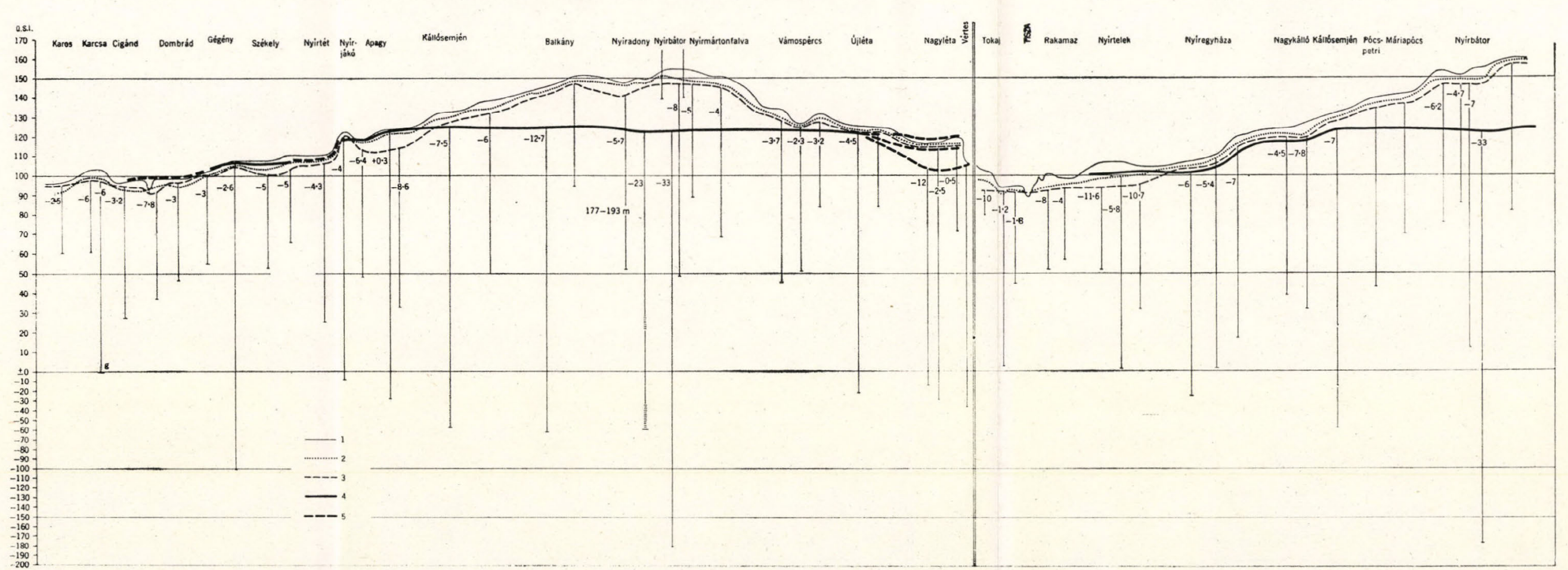

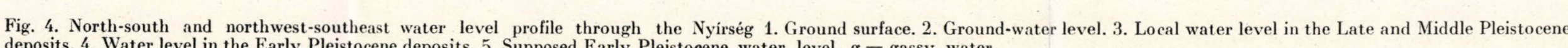




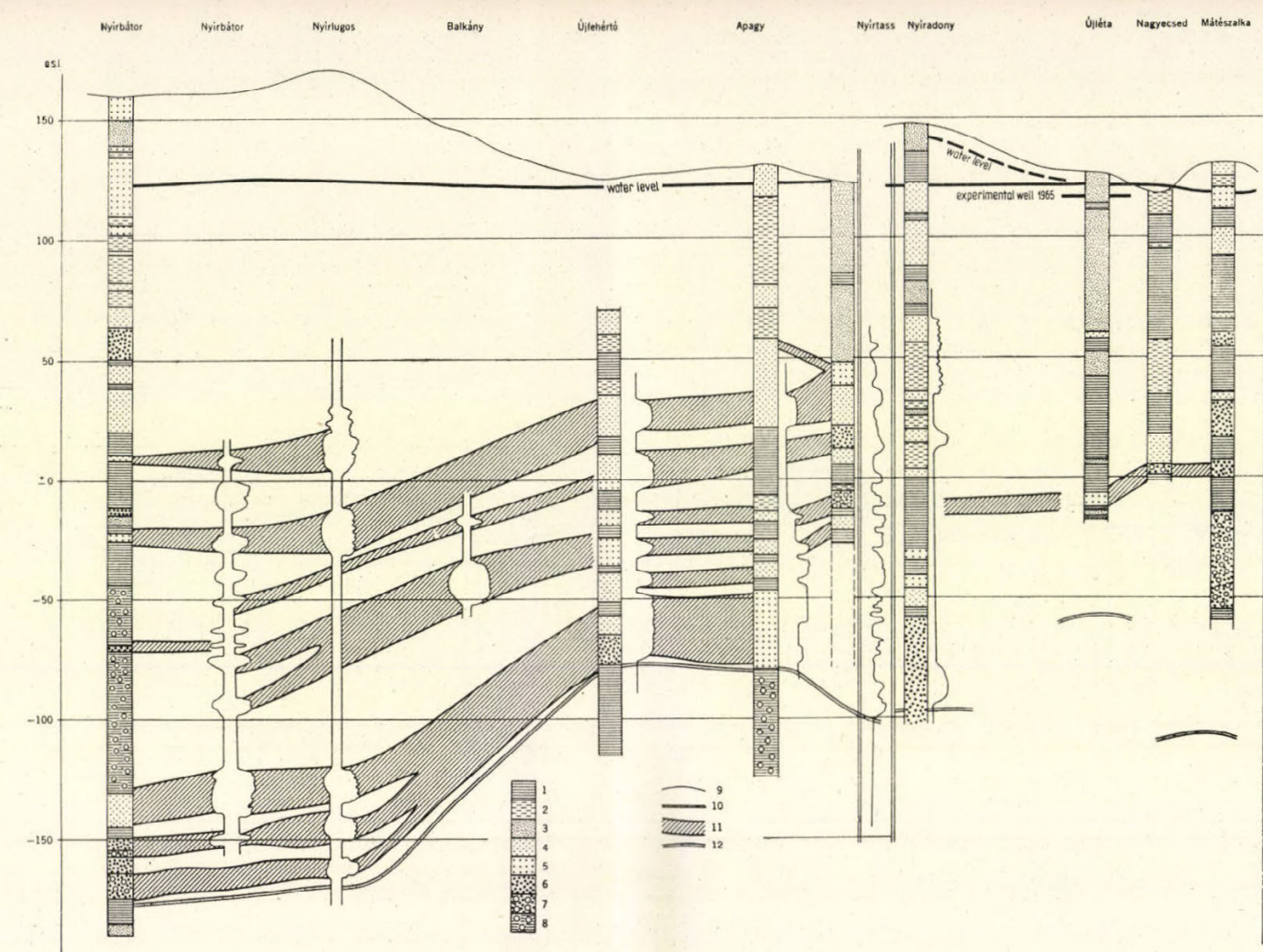

Fig. 5. Sketch. profile of geology and water levels in the Nyirség. 1. Clay. 2. Silt. 3. Fine sand.
4. Medium-fine and medium-grained sand. 5. Medium-grained sand. 6. Coarse sand. 7. Gravel and gravelly sand. 8. Gravelly clay 9. Ground surface. 10. Static level of Early Pleistocene water. 11. Sketech

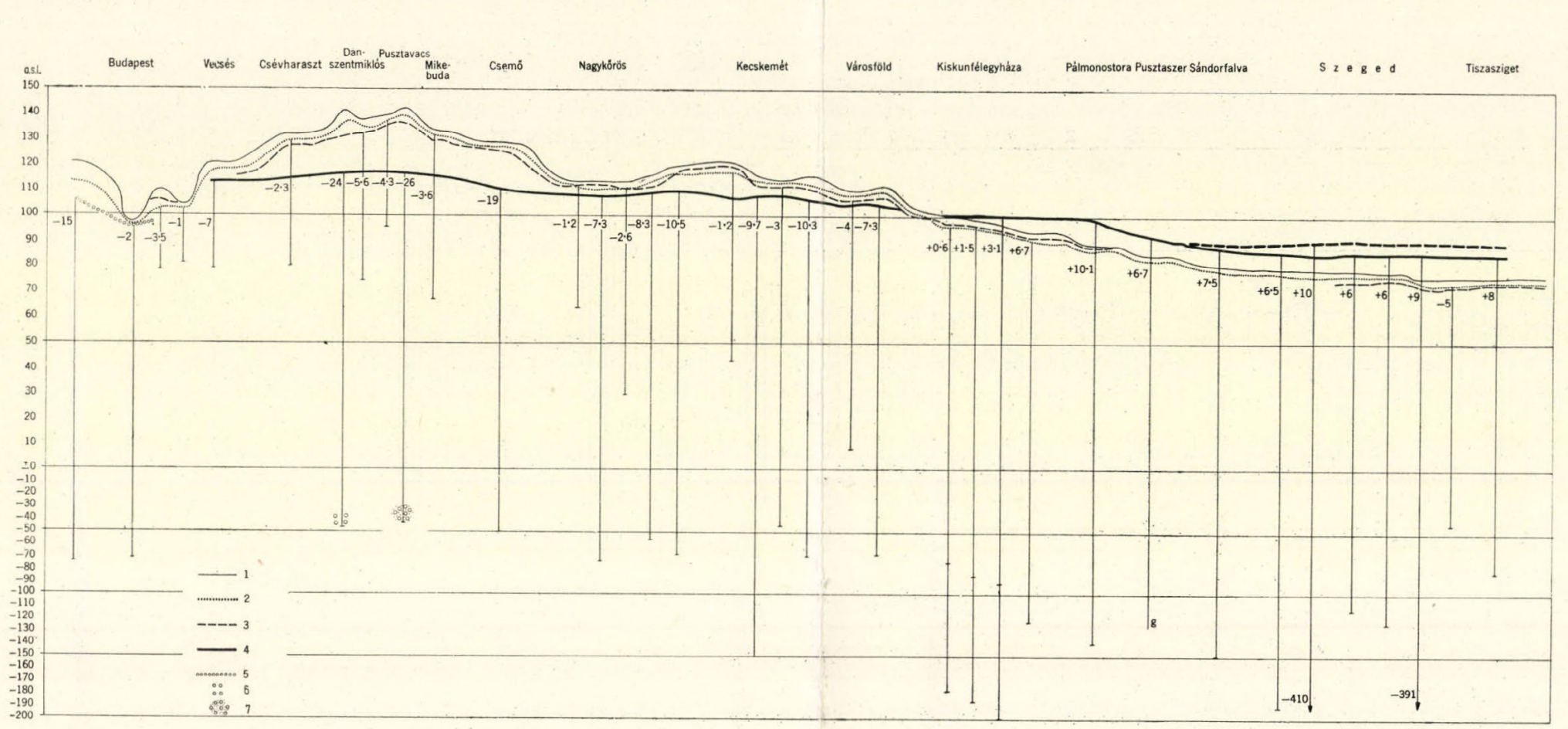

Fig. 6. Water level profile through the Pleistocene Danube valley. 1. Ground surface. 2. Ground-water level. 3. Local Late and Middle Pleistocen
water level. 4. Low er Pleistocene water level. 5. Upper Pannonian water level. 6. Gravel. 7. Gravelly coarse sand. $g$ = gassy water

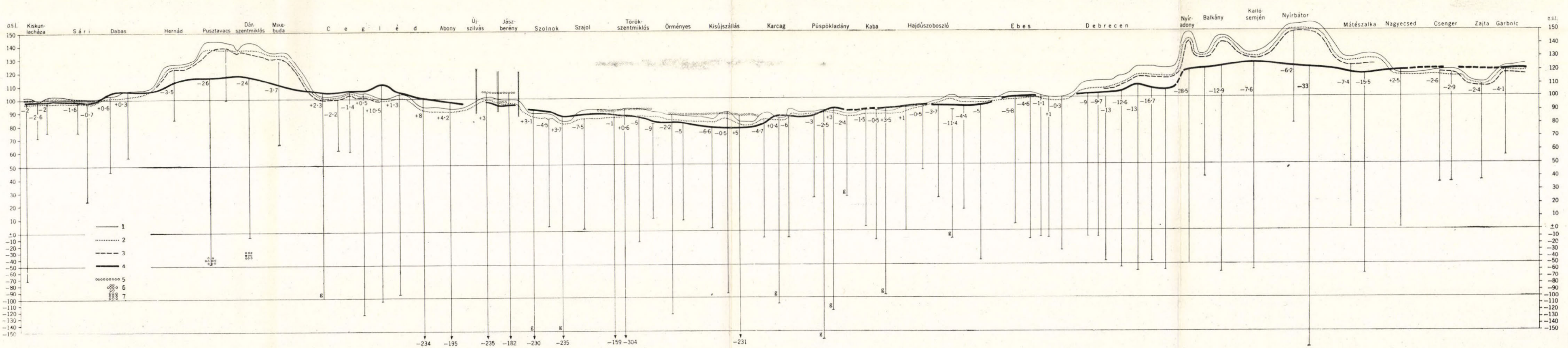

Fig. 7. East-west water level profile of the Great Plain. 1. Ground surface. 2. Ground-water level. 3. Local Late and Middle Pleistocene water levels. 4. Early Pleistocene water level. 5. Upper Pannonian water level, 6. Gravel. 7. Gravelly sand 
of Paleozoic or Mesozoic age of the basement, or floundered volcanic masses, e.g. the Nyírség and Nagykőrös. Conversely, in the regions of positive pressure state the basement tends to be deeper than elsewhere. In the authors' earlier publications (Földrajzi Értesítő 1964, 2 and Studies in Geography No. 2, 1964) a more direct relationship between geological structure and pressure distribution was summarized. In those studies the static levels observed in wells, as functions of the gradients of the negative or positive pressure state, were reduced to the level corresponding to the true pressure of water tapped at a depth of $100 \mathrm{~m}$. However, as has been pointed out above, a depth of $100 \mathrm{~m}$ still yields local pressure in most cases, which reflects the geology through the relief whose shaping it influenced. In the cited publications, the facts and their interrelations are correct, but the method-the reduction of pressures to a surface $100 \mathrm{~m}$ below the ground surface-focussed attention on the local effects and prevented recognition of pressure compensation over larger distances.

f. What has been stated concerning the positive and negative pressure state refers strictly to water stored in the Pleistocene deposits. However, in numerous instances it has also been found to apply to the pressure in thermal wells tapping Uppèr Pannonian deposits at depths of 700 to 1,200 m. For instance, two typically "negative" pressure-state areas are Lajosmizse and Kiskunhalas, $80 \mathrm{~km}$ apart. At Lajosmizse, the static level of a thermal well $800 \mathrm{~m}$ deep is $109 \cdot 14 \mathrm{~m}$ above sea level, and $24.7 \mathrm{~m}$ below the surface. At Kiskunhalas, the static level of a thermal well, $988 \mathrm{~m}$ deep, is $111.2 \mathrm{~m}$ above sea level and $20.8 \mathrm{~m}$ below the surface. At the same time, at Csongrád, a town in an area of strong positive pressure-state, which is approximately $70 \mathrm{~km}$ from both the above-named localities, a thermal well yields water rising $21.3 \mathrm{~m}$ above the ground surface. However, this is only $105 \cdot 3 \mathrm{~m}$ above sea level. The town of Kiskunfélegyháza is near the centre of the triangle subtended by the three foregoing places, in an area of positive pressure-state. Its thermal well yields water rising $6.1 \mathrm{~m}$ above the surface, to an altitude $105.1 \mathrm{~m}$ above sea level, which is almost exactly the same as at Csongrád. In this area of about $80 \mathrm{~km}$ radius, the difference in absolute water levels is but $5 \mathrm{~m}$, whereas when the differences are referred to the ground surface they attain $50 \mathrm{~m}$. Similar observations have been made in the Nyírség area. The thermal well at Mátészalka, situated in a region of negative pressure state, has a static level $5 \cdot 2 \mathrm{~m}$ below the ground surface, or $113 \cdot 8 \mathrm{~m}$ above sea level. At Nyíregyháza (Sóstó), $60 \mathrm{~km}$ away, the level is $11.3 \mathrm{~m}$ above the ground surface, but at almost the same altitude above sea level $(113 \cdot 0 \mathrm{~m})$ as at Mátészalka. These thermal wells all tap the porous medium-, fine- and extra-fine-grained sand horizons of Upper Pannonian age. In these sediments, the limit gradient at between 700 and $1,200 \mathrm{~m}$ below the surface is still but 15 to $60 \mathrm{~cm}$, so that the limit-gradient cannot possibly impede pressure compensation.

7. The relationships outlined above may, among others, serve as a foundation for the interpretation and critical evaluation of the principal theories of pressure distribution.

a. Let us consider first the so-called classical artesian law, occupying a position of prim $r$ importance in some textbooks and in numerous papers abroad, but whose use has lately been neglected in Hungary. This law is to some 
extent rehabilitated in this paper, as it certainly plays a decisive part in controlling the static water levels in the Early Pannonian deposits. However, even within the Great Plain this is not uniformly and unequivocally true. Its validity is restricted to large isolated structural units. Our profiles and map showing the static levels of the Early Pleistocene beds over the whole Great Plain conclusively prove this point. Of the profiles, let us refer only to one (Fig. 7): we shall revert later to the discussion of the map.

b. Investigating the relationship between the relief, the thickness of the deposits and the water pressure, A. Rónai (1963) considered pressure resulting from the sediment load to be the decisive factor. "Pressure acting upon the water stored in the Quaternary deposits ... is in a general way proportional to the thickness of superincumbent sediments. This is the only way to explain why, despite differences in level of 100 to $200 \mathrm{~m}$, which also occur in the Great Plain, the water table invariably lies near the surface." The present author also attributes in essence the water pressure in aquifers near the surface directly to sediment load. Even in regard to static water levels in the Early Pleistocene deposits, one cannot exclude the influence of local factors such as the elevation of the surface, and the total thickness of sediments between the ground surface and the aquifer. But the influence of these is neither immediate nor exclusive. They contribute to formation pressure through their interaction to attain equilibrium, as it were, with load pressures acting over large areas, and over the entire hydrogeological structural unit. Hence, pressure in the Early Pleistocene aquifers is a resultant of local and remote pressure components.

c. In the above-cited paper, Rónai also attempted to interpret the mechanism through which load pressure acts. He assumed that, in an aquifer consisting of gravel, load pressure is derived exclusively from the pebbles, whereas in clay interstitial water also produces part of the load. Hence, according to Rónai, we should obtain a lower pressure from gravels. J. Urbancsek (1963a) is of the opinion that, even in fine-grained sediments, none of the load pressure is borne by interstitial water. However, he raised the problem of grain size with some emphasis: " . . a coarse, gravelly sand or an even coarser sediment is required to make formation pressure decrease downwards." We have investigated this point statistically for data from 600 wells. The conclusions that have been reached are as follows. (1) In typical regions of positive pressure state, 46.7 per cent of the stratigraphic column is clay, 13.3 per cent is silty sand and 40 per cent is sand and gravel; the scatter between individual wells is very great, and the percentage of clay varies from 16 to 67 per cent. (2) In typical regions of negative pressure state, 36 per cent of the stratigraphic column is clay, $13 \cdot 3$ per cent is silty sand and 46 per cent is sand and gravel, the extremes for the clay being 13 and 60 per cent. The percentages and absolute deviations are almost identical. The direct influence of grain size upon pressure distribution as postulated by Rónai and Urbancsek is not borne out by this evidence.

The grain size of the aquifer may, however, play a role in the rates of horizontal and vertical pressure compensation, and we have to regard it as a modifying influence. In coarser-grained deposits, pressure is propagated over greater distances. In fact, in the regions of positive pressure state the Early 
Pleistocene deposits are usuallyco arser-grained: this is why pressure transfer from adjacent and more elevated regions can take place. Incidentally, it has already been pointed out in other papers by the author that in areas of positive pressure state - as proven by a large body of statistic materialhigher pressure is found in the coarser-grained deposits, in direct contradiction to Urbancsek's views.

\section{PRESSURE DISTRIBUTION IN THE EARLY PLEISTOCENE DEPOSITS OF THE GREAT PLAIN}

The author has constructed a contour map of the static water level of the Early Pleistocene aquifers of the Great Plain (Fig. 8) which permits further observations and conclusions to be made.

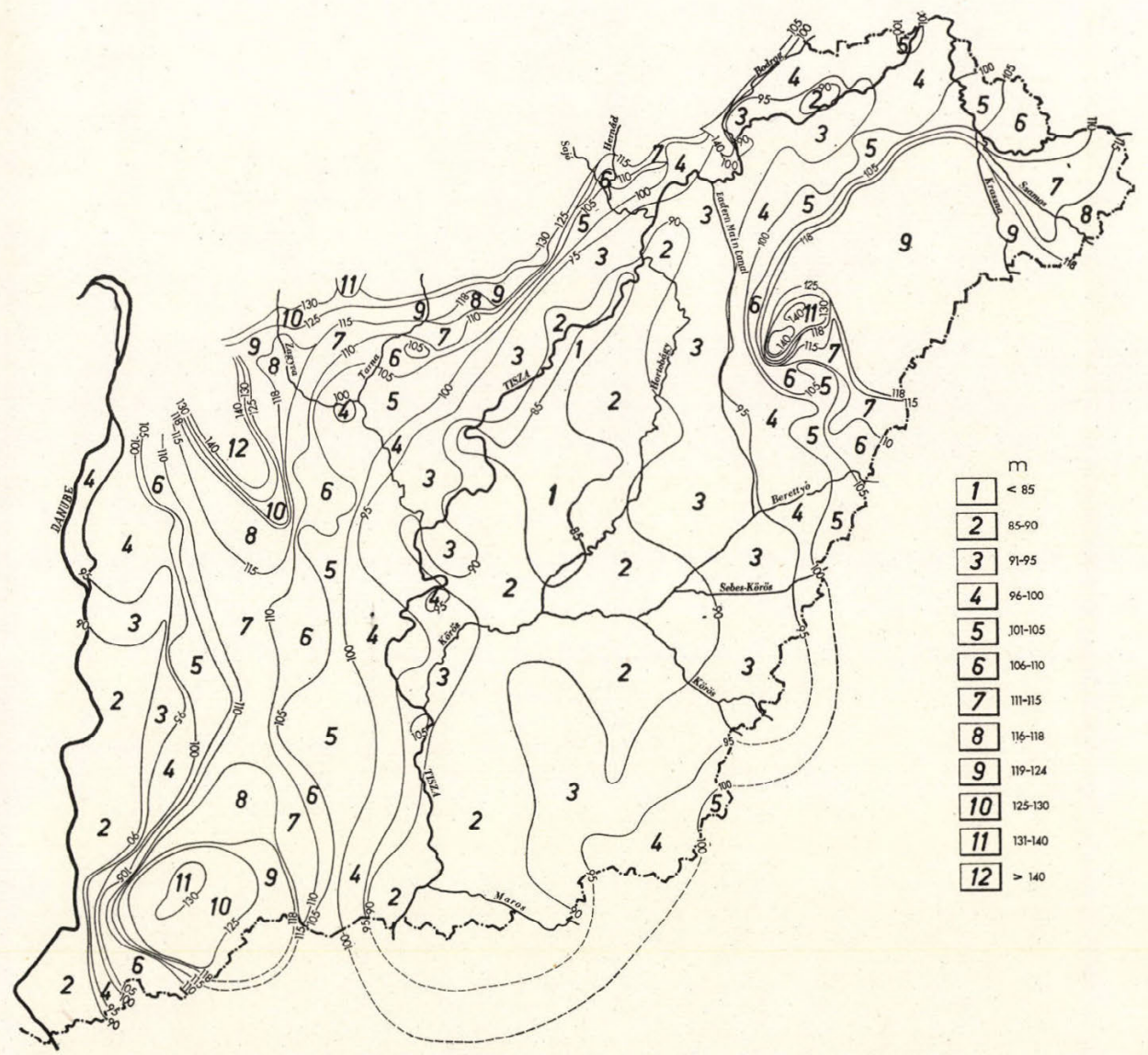

Fig. 8. Contour map of static water levels of Early Pleistocene aquifers (static levels referred to sea level). Designed by L. Simon 1965 
The static water level of these aquifers forms an interconnected depression similar to the topography of the Great Plain. The water level generally parallels the surface topography: (1) it is highest in the most elevated areas (the Nyírség, the Danube-Tisza Interfluve, and the northern margin of the Great Plain). (2) It presumably rises also towards the southern, southeastern and eastern margins of the basin as indicated by the dashed contours outside Hungarian territory. (3) The Pannonian block at Hajdúhadház-Hajdúböszörmény, the Gödölló-Ceglédbercel rise, in the northwestern part of the area between Danube and Tisza, and the Jánoshalma Plateau, in the southwestern part of this same area, are "peculiar" features of the Great Plain structure, and also stand apart as regards underground water level. (4) The water table is also higher over the buried hill in the southeastern part of the Great Plain, where the ground surface is more elevated as well. This feature is overlain by the Pleistocene alluvial fan of the Maros River, which conducts pressure from the southeastern parts of the Great Plain which are beyond the Hungarian frontier. This is why this alluvial fan is one of the "most active centres" of the entire ground-water system of the Great Plain. Its effect can be traced up to the confluence of the Tisza and Triple Körös. A similar effect might be attributed to the Gödöllö-Ceglédbercel rise, which, however, behaves more like the northern basin margin rather than an alluvial fan. Marginal pressures are transmitted towards the centre of the basin at deep levels by the Pleistocene alluvial fan of the Zagyva from the NW, and by the Pleistocene alluvial fan of the Tisza and Szamos, which underlies the Berettyó River in the area south of the Nyírség. The Jánoshalma Plateau and the Hajdúböszörmény block, already mentioned above, are local buried Pannonian horsts which, although affecting the pressure distribution of the area around them, do not transmit pressure from the basin margin.

Besides the similarities one should also point out the deviations between the pressure surface and the ground surface of the Great Plain. The main deviations are the following: (1) The pressure surface does not follow the smaller details of the ground surface, as illustrated with particular clarity by the Nyírség area. Here, an altitude difference of $60 \mathrm{~m}$ entails a water level differential of less than $4 \mathrm{~m}$. (2) The deepest part of the pressure surface does not correspond with the lowest level of the land which is at the confluence of Tisza and Maros, but is found along the Middle Tisza river and in the adjacent Nagykunság region around Karcag and Túrkeve.

From the above-described features of the pressure distribution, the following main conclusions can be drawn:

a. Over the entire Great Plain, pressure distribution is in equilibrium. This equilibrium is the resultant of excess pressure in tectonically, stratigraphically and physiographically determined areas which is balanced by pressure-compensating flow. The main factor in the loss of head is friction, composed not only of tensions developed during relative displacement, but also of the so-called "rest friction of water" which, varying with absolute pressure, produces the limit gradient as defined by the above formula. The hydrodynamic situation can also be substantially influenced by geological factors such as the considerable variety of grain sizes in the deposite forming the aquifers, and the non-homogeneity of the strata. For instance, a 10 per cent silt content 
in the sand of an aquifer, which cannot be recognized in a slush sample, reduces by half the seepage rate, given by the Darcy relationship, for the sand fraction alone. Displacement along fault lines can disturb the continuity of an aquifer, giving rise to sudden pressure drops, which need not be accompanied by even a transitional fringe.

Faults occasionally provide lines of upward seepage from deeper aquifers. In karst reservoirs this entirely is a trivial phenomenon, although its occurrence can be proved, in some instances for porous reservoirs. The most striking example is the case at Tiszakécske. Here, an extremely high and anomalous geothermal gradient of $1{ }^{\circ} \mathrm{C}$ for every 7 meters is found above an oblique fault plane. The high geothermal gradient and the sudden increase in the Clion content of the water are incontrovertible proof of an up-surge of saline thermal waters from below. However, beneath the fault plane the geothermal gradient becomes normal for the Great Plain area. In a well $225 \mathrm{~m}$ deep at Tiszakécske, which undoubtedly taps the Early Pleistocene yielding 1,500 litres of artesian water per minute at a temperature of $42^{\circ} \mathrm{C}$, the static level is 4 to $5 \mathrm{~m}$ higher than in the surrounding localities. This proves that the water surging along the fault plane also influences local pressure distribution.

One should not, however, regard recharge from below as a general phenomenon. The hypothesis that the Pleistocene aquifers are regularly recharged from deeper zones by water in the form of steam was put forward by I. Balló, who raised the problem of why neither the yield, nor the pressure of wells in the Szeged area had decreased, despite a daily extraction of eight to ten thousand $3 \mathrm{cu} . \mathrm{m}$ for a protracted period of time. The fundamental idea of his interesting explanatory hypothesis is that, water in the form of steam, moves relatively easily through clay and silt, i.e. through pores one order of magnitude smaller, than when in liquid form, and that where the limit-gradient effectively impedes the flow of water, steam is still free to move. To refute this hypothesis on physical grounds would lead us far afield. But in the Szeged case the assumption of recharge by steam from below is superfluous because Szeged is situated over the tectonic graben that once contained the Pleistocene Danube. The Pleistocene complex is $600 \mathrm{~m}$ thick here, and the Levantine sediments underlying it are also highly arenaceous. Moreover, Szeged is surrounded by an "amphitheatre" of high-pressure areas. Hence, the possibility of copious recharge both laterally and from below exists.

Just the opposite situation prevails at Debrecen. Here, the Pleistocene complex is $200 \mathrm{~m}$ thick, but its sandy horizons wedge out eastwards, while the underlying Levantine deposits which are $200 \mathrm{~m}$ thick consist of clayey sediments. Towards the NE, the area is "overshadowed" by the Pannonian horst of Hajdúböszörmény. Ground-water communication with the Nyírség is restricted to a narrow corridor of north-northeasterly direction. This is why even the original pressure in the Early Pleistocene at Debrecen, as revealed by observations in late 19th century wells, was of "transitional" type, and lower than that under the Nyírség. Large-scale exploitation has resulted in a decrease of pressure already mentioned farther above, which is not reversible, however.

The "overshadowing" effect due to the geological structure, and resulting in a pressure drop in the Debrecen area is duplicated in the Middle-Tisza 
region, where the minimum pressure for the entire Great Plain is found. Here, the aquifers are of finer-grained material than in the marginal parts of the Plain, and thus contrast with the alluvial fan complexes of the Nyírség and the Danube-Tisza Interfluve. In the northern and northeastern vicinity of the Middle Tisza region there are two large depressions, those of the Jászság and of Heves County. In all probability, however, these depressions were formed by very gradual subsidence, and without any episode of sudden foundering which would have produced coarser-grained material. Hence, their Pleistocene filling is largely clay and clayey silt, which are intercalated with thin layers of fine-grained sand. This type of deposition is unsuitable for the transmission of pressure from the northern basin margin, and amounts for the pressure minimum developed in the Middle Tisza region rather than at the confluence of the Tisza and Maros the lowest part of the gound surface.

b. Despite abundant local features, the Early Pleistocene aquifers of the Great Plain constitute an interconnected system whose pressure distribution is governed by a unique mechanism. It is only in the areas over the buried Pannonian blocks that this unique mechanism acts with reduced intensity or not at all.

c. The above considerations and the map permit some conclusions to be drawn concerning the problem of recharge. Firstly, it is obvious that no seepage can take place from a low-pressure to a high-pressure locality. Hence, the Nyírség aquifers cannot be recharged from the north-northeast, nor can those of the Danube-Tisza Interfluve be recharged from the direction of the Mátra Mountains. On the other hand, recharge in the Szeged area is possible from any direction.

The state of equilibrium broadly means that the Early Pleistocene aquifers contain static water reserves. It follows from the above-outlined mechanism that in a closed basin water outflow cannot be greater than that required to maintain the state of equilibrium. As long as the equilibrium is not upset by structural movements or by large-scale extraction of water, the reserve remains the same.

d. The conclusions thus far are all based on the hypothesis that the present distribution of pressure came into existence over the entire Great Plain basin during the Pleistocene and Holocene. It is, however, justified to suppose that in some hydrogeologic units, particularly in the marginal alluvial fans, pressure distribution evolved much more rapidly. Moreover, one should consider the possibility that pressure compensation throughout the Great Plain has not even today attained the full equilibrium, corresponding to the actual structural and lithologic situation (always allowing for equilibrium being a relative state). From the practical viewpoint this means that in an alluvial-fan area the total reserve is open to exploitation, whereas towards the centre of the Plain and in some structurally delimited basins of local extent, particularly in the uplifted Pannonian areas, it is too optimistic to assume that the entire resource of the basin is at our disposal. It is true that in such areas pressurecompensating seepage can occur, but it is a slow process particularly in finegrained sediment. If the closed part of the basin is small, then one should perhaps count only upon the water reserve of this relatively small area. 
e. Even if the state of equilibrium over the entire Great Plain, and in local areas which are either isolated or contain aquifers of fine grained sediment, bids caution as to the exploitation of the static reserve, this does not mean that one should grossly limit water extraction, because, firstly, the possible flow velocity determined by the $\mathrm{K}$ coefficient and the limit gradient is usually greater than the velocity of natural pressure-compensating flow over geological time spans. Practice has confirmed this clearly enough. To permit the extraction of $15 \mathrm{cu} . \mathrm{m}$ of water per min at Debrecen, water has to seep through the cylindrical surface of a hypothetical Early Pleistocene disc of $10 \mathrm{~km}$ radius and $25 \mathrm{~m}$ height at the rate of $7 \times 10^{-3} \mathrm{~cm}$ per sec and at ten times that rate $\left(7 \times 10^{-2}\right)$ through an Early Pleistocene cylinder of $200 \mathrm{~m}$ radius to supply high-yield wells. Secondly, the present study, is hardly more than a review of the problems and the proposal for their solution is by a method not yet tried in practice. A more detailed study will possibly discover more resources, although it may discover also further obstacles to their exploitation. This is why it is impossible to overemphasize the importance of scientific research in this field.

\section{REFERENCES}

Almássy, E. (1966): The role of consolidation and of the limit gradient in the movement of artesian waters in Hungary. Hungarian Academy of Sciences): Seepage and Well Hydraulics Symposium, Budapest.

Balló, I. (1961): Artézi jelenségek (Artesian phenomena), Vizügyi Közlemények Vol. 43.

Fourmarier, P.: (1958): Hydrogéologie. Masson et Cie, Paris.

Juhász, J. (1958): A szivárgás vizsgálata (A study of seepage), Hidrológiai Közlöny, Vol. 38.

Juhász, J. (1966): A konszolidáció révén kitermelhető sztatikus vízkészlet számítása (Calculation of the static water reserve liberated by compaction). Hung. Acad. Sci. Seepage and Well Hydraulics Symposium, Budapest.

Magyarország hévízkútjai (Thermal water wells of Hungary). VITUKI, Budapest, 1965

V. Nagy, I. (1966): A kitermelhető felszinalatti vizkészletek meghatározásának elvi és gyakorlati kérdései (Principles and practice of determining exploitable subsurface water reserves). Hung. Acad. Sci. Seepage and Well Hydraulics Symposium, Budapest.

Orlóci, J., Török, L. and Gábos, L. (1966): A tartósan kitermelhetô rétegvíz mennyiségének becslése a vízkivétel okozta terepszintváltozások vizsgálata alapján (Estimation of durable yield of subsurface aquifers from ground subsidence). Hung. Acad. Sci. Seepage and Well Hydraulics Symposium, Budapest.

Pécsi, M. (1959): A magyarországi Duna-^ölgy kialakulása és felszinalaktana (The evolution and geomorphology of the Hungarian section of the Danube Valley). Budapest: Akadémiai Kiadó.

Rónai, A. (1961): Az Alföld talajviztérképe (Ground water map of the Great Plain), Budapest.

Rónai, A. (1963): Az Alföld negyedkori rétegeinek vízföldtani vizsgálata (Hydrogeological study of the Quaternary deposits of the Great Plain). Hidrológiai Közlöny, Vol. 43.

Schmidt, E. R., ed.: (1962): Magyarország vízöldtani atlasza (The Hydrogeological Atlas of Hungary). Budapest.

Schmidt, E. R., ed.: (1962): Vázlatok és tanulmányok Magyarország víföldtani atlaszához (Sketches and studies to illustrate the Hydrogeological Atlas of Hungary). Budapest.

Simon, L. (1963): Szerkezeti területi típusok néhány vízföldtani törvényszerüsége (Some hydrogeological relationships of areal geostructural types). Földr. Ért., Vol. 12.

Simon, L. (1964): Possibilities of Agriculture under Irrigation in the Nyírség. Studies in Geography in Hungary, 2. Budapest.

Simon, L. (1966): A pleisztocén rétegvizek nyomásviszonyai az Alföldön (Pressure distribution in the Pleistocene aquifers of the Great Plain). Földr. Ért., Vol. 15. 
Simon, L. (1967): Debrecen pleisztocén hidrogeclógiájának időszerủ kérdései (Some actual problems of the hydrogeology of the Pleistocene deposits around Debrecen). Földr. Ert., Vol. 16.

Simon, L. (1968): Az öntözéses mezögazdaság lehetöségei alföldi homokhátságainkon (Possibilities of irrigated agriculture on the sandy rises of the Great Plain). Budapest: Akadémiai Kiadó.

Urbancsek, J. ed. (1966): Magyarország mélyfúrású kútjainak katasztere (A survey of Hungarian deep drilled wells) I-II: 1963, III. Budapest.

Urbanesek, J. (1963): Jánoshalma környékének földtana és felszínalaktana (The geology and geomorphology of the environs of Jánoshalma), Földr. Ért., Vol. 12.

Urbancsek, J. (1963): A földtani felépítés és a rétegviznyomás közti összefüggés az Alföldön (The relationship between geology and ground water pressure in the Great Plain). Hidrológiai Közlöny, Vol. 43.

Urbancsek, J. (1963): Pliocén és pleisztocén üledékek szintezésének újabb lehetőségei a vízföldtani kutatásban (Some novel possibilities of correlating and subdividing Pliocene and Pleistocene deposits as used in hydrogeological research). Hidrogeológiai Közlöny Vol. 43.

Urbanesek, J. (1965): A Bodrogköz, a Rétköz, a Szatmár-Beregi síkság és a Nyírség vízföldtana (The hydrogeology of the Bodrogköz, Rétköz, Szatmár-Bereg Plain and the Nyírség). Földr. Ërt., Vol. 14. 


\section{GEOMORPHOLOGICAL RESEARCH AND MAPPING IN STRONGLY ERODED AREAS}

(Explanatory note to the $1: 25,000$ geomorphological map of the Szekszárd Hills)

by

L. Á D Á M

\section{INTRODUCTION}

Geomorphological mapping gives a welcome incentive to morphological field research. Morphological research connected with mapping acquires a new dimension in both method and utility and, as regards the requirements of economic practice, becomes substantially enriched in content as well.

It was the recognition of these circumstances that directed the attention of Hungarian workers towards geomorphological mapping, at first in the form of individual experiments which lacked a set of unifying principles (L. Ádám, S. Marosi and J. Szilárd 1959, M. Pécsi 1959, Z. Borsy 1961). In 1961, a research group in the Physiography Department of the Geographical Research Institute, making use of both the results of the cited experiments and the methods used in morphological mapping abroad (in Poland, the Soviet Union, Germany and France above all), developed the principles and symbols to be used in the small-scale (1 to 100,000 and 200,000) geomorphological mapping of this country. It was on this basis that the entire territory of Hungary was mapped: "In preparing the general geomorphological map of Hungary we were led by the principle of giving a comprehensive illustration of the geomorphological conditions prevailing in the various regions of Hungary." (M. Pécsi 1963.)

Subsequently, in 1962 and 63, the same research group developed the principles, methodological foundations and symbols to be used for the detailed geomorphological mapping of the country at a scale of $1: 25,000$ and $1: 10,000$ : it is on this basis that current detailed mapping is being carried out.

The study to be presented here, which is in effect an explanatory note to the annexed morphological map, was prepared as a first experiment in developing the principles and methods of detailed mapping.

\section{PRINCIPAL TRAITS OF THE SZEKSZÁRD HILLS}

OVERALL FEATURES OF THE MICROREGION AND ITS RELATIONSHIP WITH ADJACENT REGIONS

The Szekszárd Hills in Southern Hungary, at the foot of the Mecsek Mountains, cover an area of $200 \mathrm{sq} . \mathrm{km}$ and constitute a microregion within the rolling topography of Tolna County, which is bounded on all sides by sharply defined structural lines. 
As strikingly revealed by the morphological map (Fig. 1), the sharpest structural boundary is in the east where a stepped scarp undercut by the Danube rises steeply to between 100 and $160 \mathrm{~m}$ above the alluvial plain of the Sárköz region.

The Szekszárd area is a minutely dissected hilly microregion of considerable relief energy $(100 \mathrm{~m}$ per sq. $\mathrm{km}$ on the average, but locally - on the margins and in the central portion around Oriás Hill and the Éles ridge-it exceeds $150 \mathrm{~m}$ per sq. $\mathrm{km}$.).

Besides a number of similar and analogous features, the evolution, particularly in the geomorphological sense, of this hilly region of great relief energy differs in a number of ways from the evolution of adjacent microregions. These differences in morphology are the result of various individual features in stratigraphy, structure and history of evolution. The Szekszárd region is characterized morphologically by a dense network of deeply incised valleys of erosional, derasional, and combined erosio-derasional type, loesscovered divides and ridges spared by erosion, narrow interfluvial ridges dissected into isolated hills, steep fault scarps and substantially uplifted loess plateaux.

Watercourses of any importance are restricted to the large structural valleys, but even these have discharges of only 8 to 200 litres per sec during most of the year. The two main streams of the microregion are the Völgység and Lajvér. The smaller intermittent and perennial watercourses of the interior of the microregion discharge their waters via the two rivulets into the Szekszárd-Báta Canal and thence into the Danube.

Springs are numerous in this area of strong topography and favourable geology. All perennial streams are fed by one or several springs issuing from Upper Pannonian sands. Most springs have small yields of the order of 5 to 40 litres per sec.

There are no natural lakes of any size in the area although a few artificially dammed fishponds have been created in the Völgység, Rák and Lajvér valleys.

This microregion has a mean annual temperature of $11.4{ }^{\circ} \mathrm{C}$ which varies from a mean of $-0.7{ }^{\circ} \mathrm{C}$ in January to $22.6{ }^{\circ} \mathrm{C}$ in July, and an average annual precipitation of $670 \mathrm{~mm}$. In its natural state it was wooded steppe but most of the area is cultivated today. More than two thirds of its surface (14,000 hectares) is under the plough and in vineyards; slightly less than one-third (5,100 ha) is forest, meadows and pastureland. A closed forest stand of linden, hornbeam and oak is restricted to the highest central portion of the area which makes up 75 per cent of the entire wooded surface (1,150 ha). The remainder, 370 ha, largely consists mainly of isolated acacia woods.

The substantial proportion (2700 ha) of meadows and pastureland is due to the dense network of valleys dissecting the region. The broad straths $(0 \cdot 2$ to $1 \mathrm{~km}$ wide) became transitorial areas during the land consolidation: the drainage canals silted up, the alluvial soils became waterlogged, and as a result the meadows became sour and unusable. At present, 60 to 70 per cent of the meadows are in need of improvement.

This minutely sculptured region has a variegated soil cover which includes brown earths (Ramann's brown forest soil), deeply humified brown earths, 


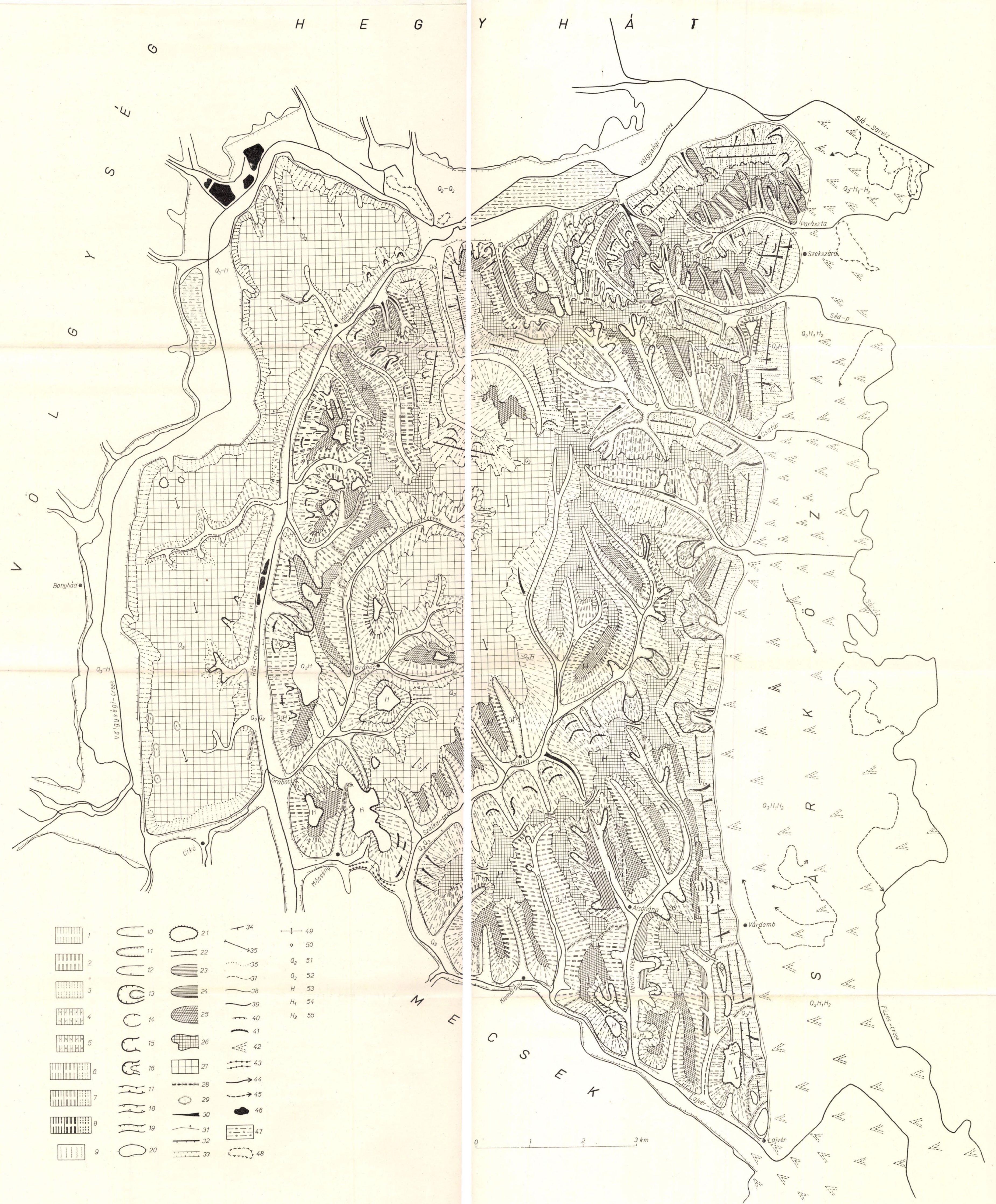

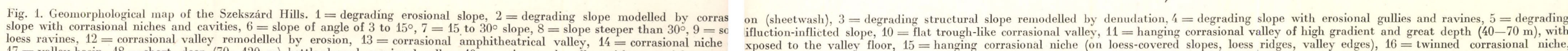

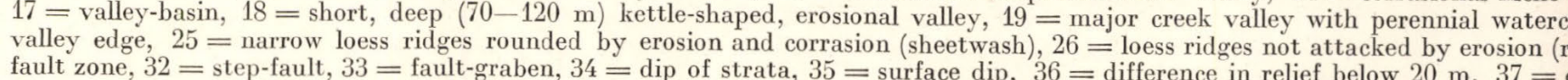

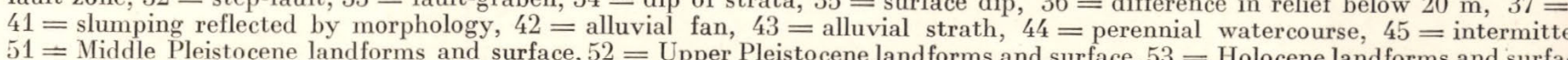
diges carrying a main water divide), $27=$ loess plat form, loess plateau, $28=$ dirt road in loess, $29=$ loess-doline, $30=$ loess ravine, $31=$ fracture line
ifferen

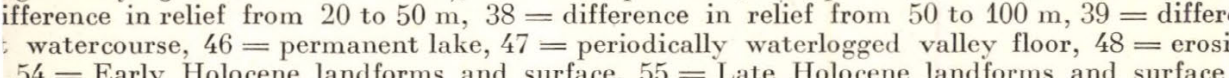


brown earths with clay illuvions, chernosems, meadow soils and deluvial soils. The most widespread type, however, is the brown earth, covering two thirds of the area under agriculture.

Owing to the intensely dissected relief, the soil cover of the area is poor. 75 per cent of the area under agriculture is intensely eroded (10,500 ha) and the remaining 25 per cent $(3,500 \mathrm{ha})$ is either moderately or weakly eroded. The situation is worse on the eastern and northern border of the area, where intensive viticulture resulted in the erosion of the entire soil profile and cultivation has been carried out for some decades on bear bed rock.

The Szekszárd Hills have no mineral wealth to speak of, and even the building materials (loess and Pannonian clay suitable for brickmaking) are of only local interest. This is one of the reasons why Szekszárd, the principal town of Tolna County, is rather backward as far as industrialization is concerned. However, there is no energy base at all for industrialization within the Szekszárd microregion proper.

The most valuable single item in the economy of this largely agricultural area is viticulture. In spite of deep soil erosion, the traditions of several centuries enable the local vine growers to produce a red wine of world renown. Except for viticulture, the region is unsuited for large-scale mechanized farming because of deep soil erosion and the dissection and steepness of the slopes. Natural conditions are much more favourable for animal husbandry and forest culture. The latter acquires particular importance because of the almost complete absence of woods in the adjacent Sárköz region which also belongs to Tolna County.

\section{SURFACE GEOLOGY}

The Szekszárd Hills and the adjacent Hegyhát and Völgység regions are built up of a variegated succession of Pliocene and Pleistocene deposits. There are also a few outcrops of basement granite and limestone but their extent is too small to plot on the annexed map.

\section{PRE-PLIOCENE DEPOSITS}

The oldest outcrop, not shown on the map, is a Lower Carboniferous granite which occurs at Kismórágy-puszta and is of a few sq. $m$ in extent only. Further Pre-Pliocene outcrops worth mentioning are blocks of Miocene (Tortonian? Sarmatian?) limestone over an area of a few sq. $m$ in the cutting of the railway tunnel near Möesény.

\section{PANNONIAN DEPOSITS}

Although the thick cover of loess and loessic deluvial deposits precludes the illustration of this fact on the morphological map, it is known from local exposures and deep drilling data that the morphology of the microregion is 


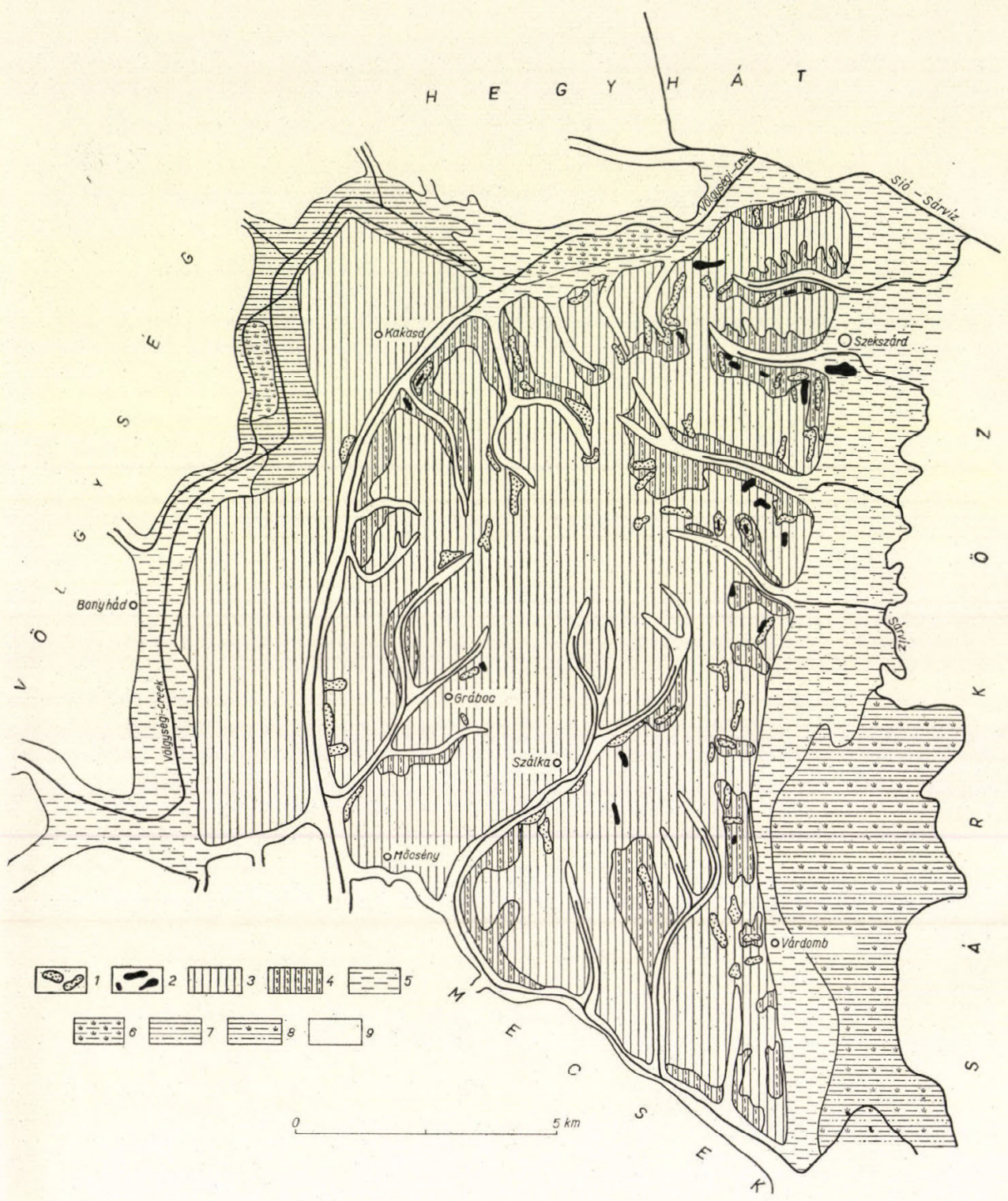

Fig. 2. Lithological map of the Szekszárd Hills. 1. Upper Pannonian (clays, sands, sandstones). 2. Lower Pleistocene red clay. 3. Typical loess. 4. Loess reworked by solifluction. 5. Slope-washed silty, sandy, loess sediment. 6. Meadow clay. 7. Silty-sandy alluvial clay. 8. Alluvial clay, alluvial silt, meadow clay. 9. Alluvial bottoms of smaller vallevs covered by slope-washed loess 
largely sculptured out of a variegated succession of Pannonian sands, sandstones, clays, sandy clays and argillaceous sands (Fig. 2). Their outcrops, however, cover no more than 2 per cent of the surface ( 400 ha); and even less

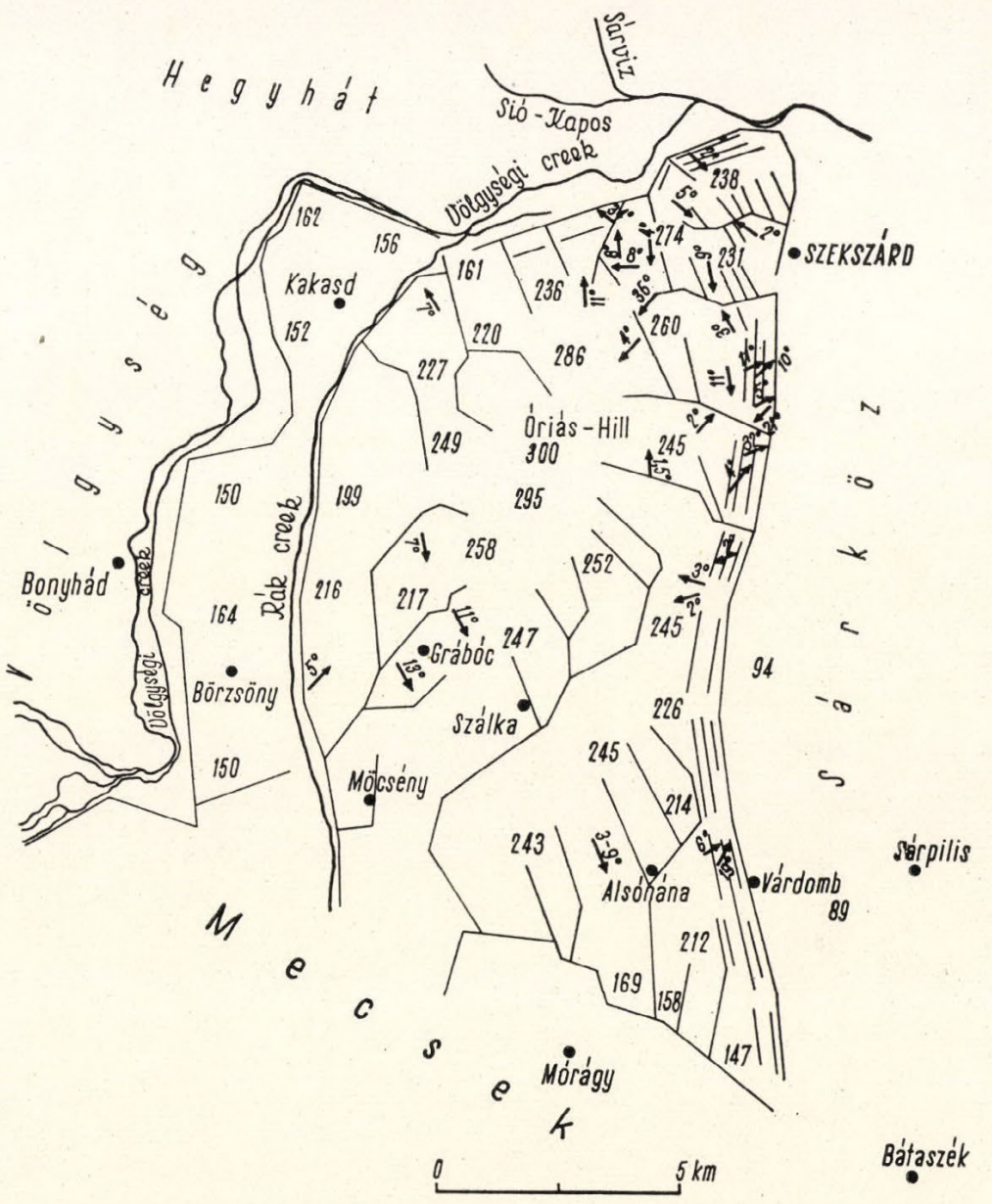

Fig. 3. Main structural lines and dips in the Szekszárd region

is shown on the map because outcrops smaller than $1,000 \mathrm{sq} . \mathrm{m}$ area have been excluded. It should therefore be pointed out that besides the outcrops on the map there are numerous smaller ones in loess gullies, deeply incised dirt roads and at the valleyheads.

According to I. Lőrenthey (1892), the Pannonian deposits constituting the Szekszárd Hills belong to the upper horizon, and contain the Upper Pannonian index fossils Congeria triangularis and C. rhomboidea. Its thick- 
ness is but 100 to $200 \mathrm{~m}$ according to borehole evidence although thicker successions might occur in fault grabens between some of the granite blocks.

In the microregion under consideration, the Pannonian deposits are fairly intensely dislocated, as shown by the sandstone strike and dip data plotted on Fig. 3. The maximum elevation of the Pannonian is in the northern part of the region where it is between 200 and $220 \mathrm{~m}$ above sea level white in the south and southeast it gradually descends to lower levels, under a cover of 20 to $40 \mathrm{~m}$ of loess, to a minimum of less than $110 \mathrm{~m}$ a.s.l beneath the alluvium of the Lajvér valley.

\section{FOSSIL RED CLAY}

The lowermost member of the Pleistocene in the Szekszárd microregion just as in the adjacent Hegyhát and Völgység regions, is a fossil red clay di ectly overlying the Pannonian. By no means ubiquitous it is of a highly variable thickness, but as it outcrops in a wide range of localities over all the region, it is justified to assume that originally it formed an uninterrupted cover over the Pannonian surface.

On the basis of field conditions and composition one may distinguish in-situ and reworked varieties of this red clay. The former variety occurs in deposits 0.3 to $0.8 \mathrm{~m}$ thick while the latter is between 3 and $16 \mathrm{~mm}$ thickness. Redeposition was mainly due to periglacial solifluction and sheetwash.

Outcrops of the fossil red clay are most frequent in the minutely dissected northeastern and northern parts of the region and the lithologic base of the morphological map indicates all outcrops of significant size. All in all, it covers an area of some 100 ha.

\section{LOESSES AND LOESSIC SEDIMENTS}

The most widespread surface formation is loess, which constitutes the substratum of the fertile soils in the agriculturally exploited areas, and various types of loessic deluvial sediments.

The average thickness of the loess is from 20 to $40 \mathrm{~m}$, although locally it may be greater. The loess cover overlies either the Lower Pleistocene fossil red clay or the denuded surface of the Pannonian.

\section{a. Typical dry-land loess}

Sixty-five per cent (10,400 ha) of the loess cover of the hill region was deposited in-situ on a dry land surface. The loess profile, however, consists of horizons of this type interbedded with various types of loessic deluvial deposits. In its lower horizons, dry-land loess usually grades into a more compact brownish-grey or yellowish-grey loess.

Large contiguous areas of typical loess are restricted to the undissected plateaux, to the broad non-eroded interfluvial divides and to the tops of the larger remnants of dissected divides (Fig. 4). Slopes furrowed by loess gullies and deeply incised dirt roads are also typical (Figs. 2, 5). 
In spite of its considerable thickness, the loess in the Szekszárd region was mainly deposited during the last glacial period. In the lower horizons, however, pre-Würm loesses also occur. The more or less compacted clayey loesses and strongly compacted loesses are usually regarded as pre-Würm, although

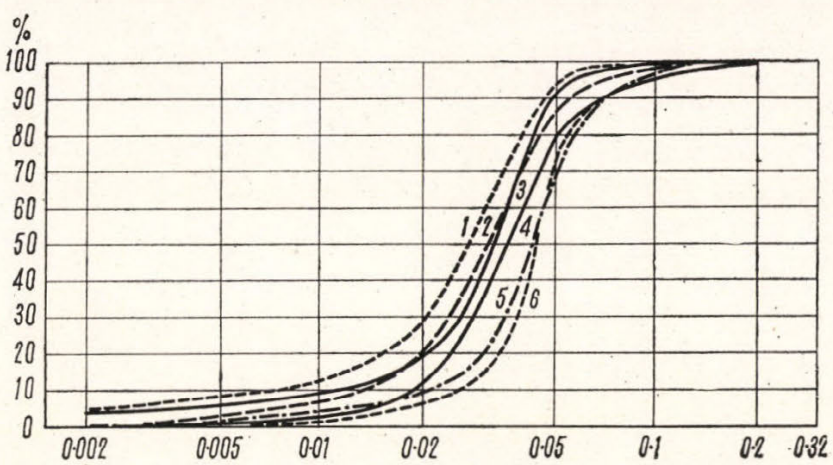

Fig. 4. Grain size distribution of four loess samples from plateau tops

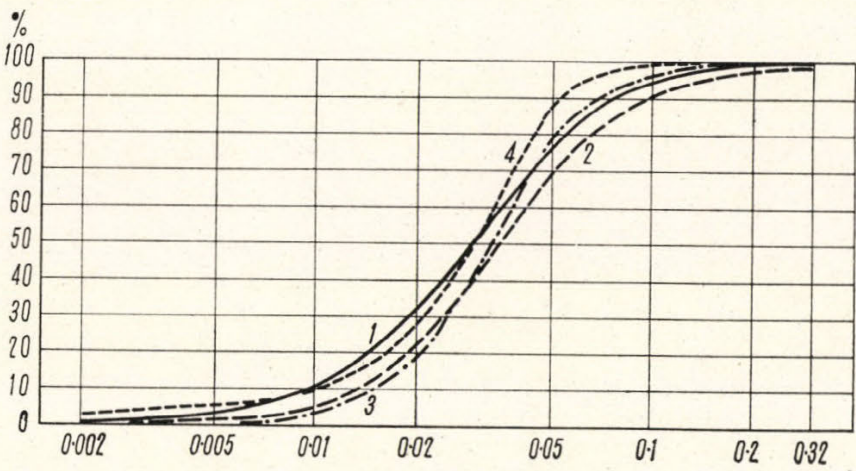

Fig. 5. Grain size distribution of six typical loess samples from sloping sites

no precise loess chronology can be established on the basis of existing knowledge.

Typical loess is usually subdivided by two layers of reddish-brown fossil soil. Profiles with three and even five such fossil soil horizons are known (Kálvária Hill), but such a number is an exception rather than the rule.

b. Redeposited (deluvial) loessic deposits

Redeposition was either by periglacial solifluction or by sheetwash. The loessic deposits thus formed constitute 35 per cent $(5,600 \mathrm{ha})$ of the entire loess-covered surface. 
The lithologic base of the morphologic map reveals that among deluvial loesses, the type reworked by solifluction is most widespread. Solifluction is proved by chaotic intermixture with Pannonian sediments and by the presence of irregular rags of fossil soil and various forms of kneaded-in sacks. The material is foliated and shard-like rather than properly stratified. The change in material is clearly reflected by the grain size distribution curves (Fig. 6).

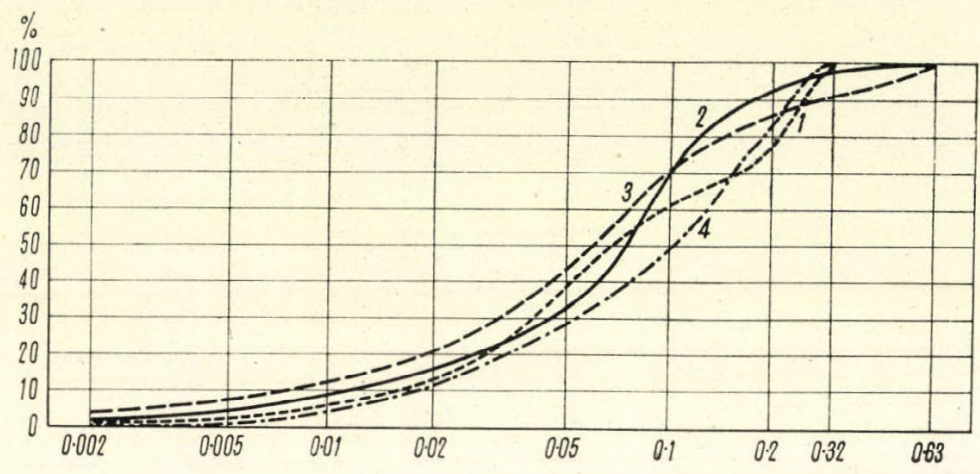

Fig. 6. Grain size distribution of four samples of loess reworked by solifluction

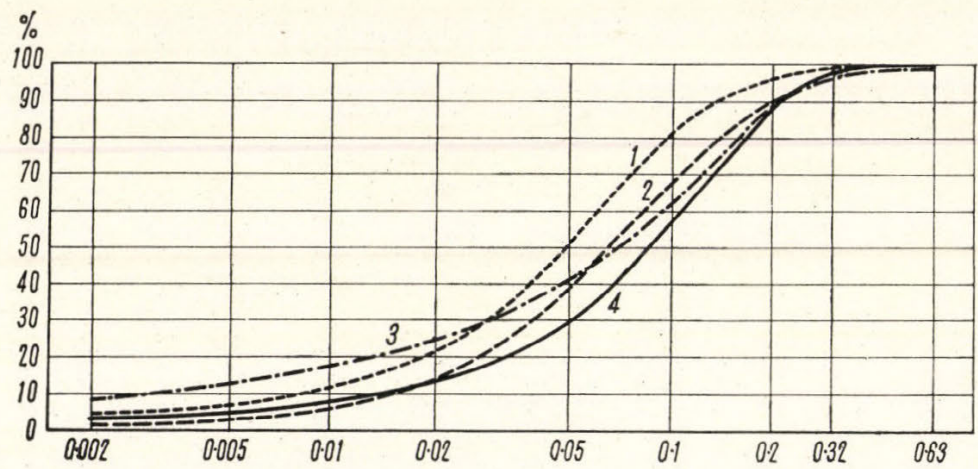

Fig. 7. Grain size distribution of four samples of finely stratified, slopewashed loess

Although not revealed by the map, in the area under consideration loess reworked by solifluction is not restricted to the surface: on the contrary, it occurs in lower levels of the loess profile, interbedded with undisturbed loess, as proved by solifluidal structures in the fossil soil horizons.

Deluvial loess reworked by sheetwash ("sheetwashed loess") is also fairly widespread. Its extent is, however, not shown in full by the map, as it usually occurs intermixed with typical loess strata, grading into the lower portions 
of the same, and interbedded with solifluction loess. It rarely occurs on the surface, therefore.

The intense vertical dissection with steep slopes resulted in the removal of most of the reworked loess from the interior of the area, and its deposition in the surrounding marginal plains. This is why the thickness of reworked loess locally exceeds $10 \mathrm{~m}$ in large contiguous areas as shown on the map.

In the mapped area, there is a considerable variety of redeposited loess types. Redeposition is clearly revealed in all cases by the grain size distribution curves (Fig. 7).

\section{FLOODPLAIN DEPOSITS}

A surface of 3,000 ha is covered in the Szekszárd region by floodplain deposits (silt, clay, sand, sandy silt, silty sand). The straths of the larger valleys locally carry alluvial fillings up to $10 \mathrm{~m}$ thick and above. Some of the alluvia are large-capacity aquifers of practical importance (Völgységi valley).

\section{GENETIC MORPHOLOGICAL FORMS AND FORM GROUPS}

Geomorphologically this region consists of a variety of elements sculptured by derasion and erosion.

Of the structural features, grabens between parallel faults and fault scarps remodeled by periglacial solifluction, slumps and sheetwash are most conspicuous.

Besides the structural features, the main outlines of the relief are largely determined by the narrow, and fairly high loess divides and ridges, which constitute the principal divide and the secondary divides of the region, by the structurally pre-formed erosional and derasional valleys and by the plateau remnants modeled by derasion, sitting on narrow ridges and on the valley flanks.

Moreover, the morphological image of this micro-morphological region includes elevated loess plateaux, the peculiar forms of denudation and erosion of loess, and landslide and slump forms. Anthropogenic forms and forms due to solifluction are, despite their considerable extent in some parts of the region, only accessory landscape elements.

\section{STRUCTURAL FORMS}

Here we shall discuss surface forms, primarily determined by structural displacement, whose outlines reflect the subsurface structure up to this day.

\section{Structural grabens}

The main structural-morphological trait of such valleys is that they consist of a linked chain in effect of more or less deeply subsided graben elements limited on two sides by parallel faults. Non-uniform subsidence of the individ- 
ual elements resulted in poor drainage and the formation of swamps on the graben bottoms, which remained a feature of the landscape until human intervention. Further common features are the depth of the valleys (100 to $130 \mathrm{~m}$ ) and the width of the straths $(300$ to $1,000 \mathrm{~m}$ ) as well as the almost insignificant gradient of the silted-up valley floors.

The valley traces invariably reveal a chessboard pattern of faults and suggest that the graben elements linked by a common watercourse were not formed simultaneously, but effected the watercourse as and when their subsidence reached a suitable level.

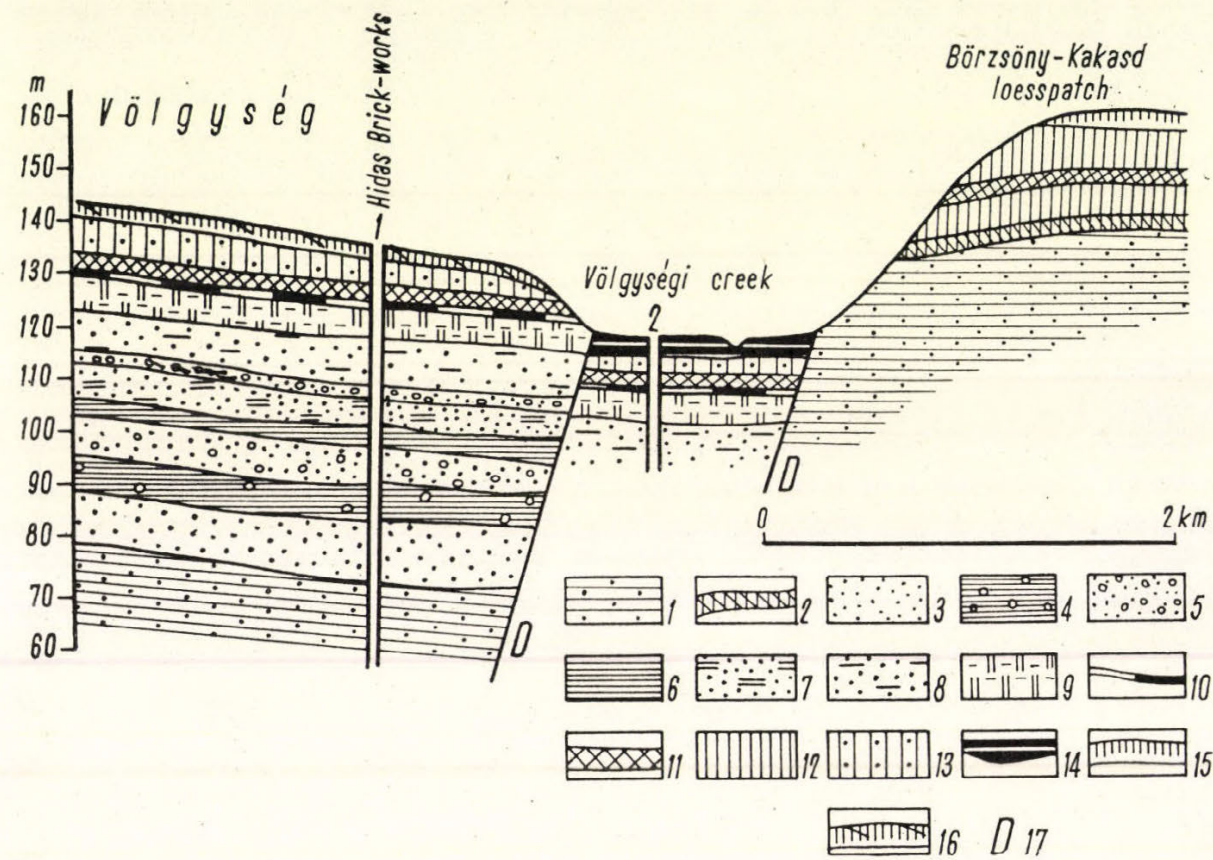

Fig. 8. Cross profile of the Völgység valley south of Bonyhád. 1. Upper Pannonian (clays, sands, sandstones). 2. Lower Pleistocene red clay. 3. Light-grey, fine-grained micaceous fluvial sand. 4. Greyish-yellow gravelly clay. 5. Sandy gravel. 6. Greyish-brown stiff clay. 7. Silty clayey sand. 8. Grey, very silty, fine-grained micaceous fluvial sand. 9. Redeposited sandy loess. 10. Red-brown fossil soil horizon. 11. Dark brown fossil soil horizon with steppetype soil. 12. Pale yellow typical loess. 13. Greyish yellow sandy loess. 14. Meadow clay. 15. Brown earth. 16. Chernozem brown forest soil. 17. Fault, fault swarm

Subsidence during the Late Pleistocene and Holocene was quite rapid and uneven, which accounts for the fact that identical deposits on both sides of a valley (Pannonian deposits, granite, etc.) today lie at altitudes differing by 100 to $120 \mathrm{~m}$ (Fig. 8).

This is one of the causes of the marked asymmetry of the grabens. As compared with the steep and tall slopes which rise far above $200 \mathrm{~m}$ at slope angles 
of 10 to $30^{\circ}$ on the right flanks, the slopes on the left flanks are gentle and low and rise to 110 to $140 \mathrm{~m}$ with angles of 5 to $8^{\circ}$.

From the beginning of their evolution to this day, the structural grabens have undergone a complicated history not reflected by the map. Let us therefore mention that during the Middle and Late Pleistocene the Lajvér valley, for example, drained the waters of the Bonyhád Basin (including among its tributaries the creek in the Rák Valley), whereas the east-west section of the Völgység valley formed the continuation of the Alsóhidas valley and as such drained the waters of the Southern Hegyhát which lacked a compact drainage system in the Late Pleistocene. The broad strath of the Völgység valley was a swampy depression for a long time, filled with up to $20 \mathrm{~m}$ of fluvial sediment. The permanent drainage of the Völgység valley evolved some time during the Late Pleistocene, when the Danube vacated its Early Holocene bed in the Sárköz and cut itself a deeper bed farther away. The resulting increase in relief energy incised a common watercourse into the string of valley segments of various age.

Step faults in the marginal areas

Of the structural features, the step-fault scarps modified by periglacial solifluction, slumps and sheetwash in the borderzones of the region are most conspicuous. Despite the softness of the sediments and mass wasting on a large scale, these step faults have retained much of their original form.

The best-preserved and most impressive fault scarps are those on the northern and eastern borders of the region. The fairly broad (150 to $200 \mathrm{~m}$ ) fault steps are conspicuous even at a distance because their steep fronts rise quite suddenly 100 to $160 \mathrm{~m}$ above the alluvial plain of the Danube and the Völgység rivulet, respectively.

The well-preserved fault steps are characterized by steep scarps $\left(10\right.$ to $\left.18^{\circ}\right)$, and gently sloping $\left(3\right.$ to $\left.5^{\circ}\right)$ broad step surfaces $(150$ to $200 \mathrm{~m}$ ). Their origin is revealed both in their morphology and by the dips of the beds and faults measured in exposures on the scarps. Accordingly, the fault steps of the eastern border, facing the Sárköz region, formed between marginal faults of N-S and NNE-SSW strike, brought about by the uplift of the hill region and the subsidence of the Sárköz in the Late Pleistocene. Faulting entailed quite substantial tilting in some of the fault blocks. As a result, the Pannonian deposits delimited by the step faults is nowhere horizontal. They are invariably tilted towards the NE or ENE, i.e.towards the Sárköz. The tilt of the Pannonian aquifers simplifies the utilization of the waters stored in them.

On the eastern and northern margin of the region it is usual to find double or triple fault steps. Figures 9 and 10 show two cross-sections of the eastern step-faulted margin. They also demonstrate the areal extent of the loess, interrupted by one or two fossil soil zones, covering the eastern margin of the region. Since the loess covering the step surfaces cannot be older than the Würm-glaciation, the displacements of the fossil soils permit an approximate dating of the step faults.

According to the above-mentioned profiles, the stepped downfaulting of the eastern margin of the region took place during the last glacial period since 


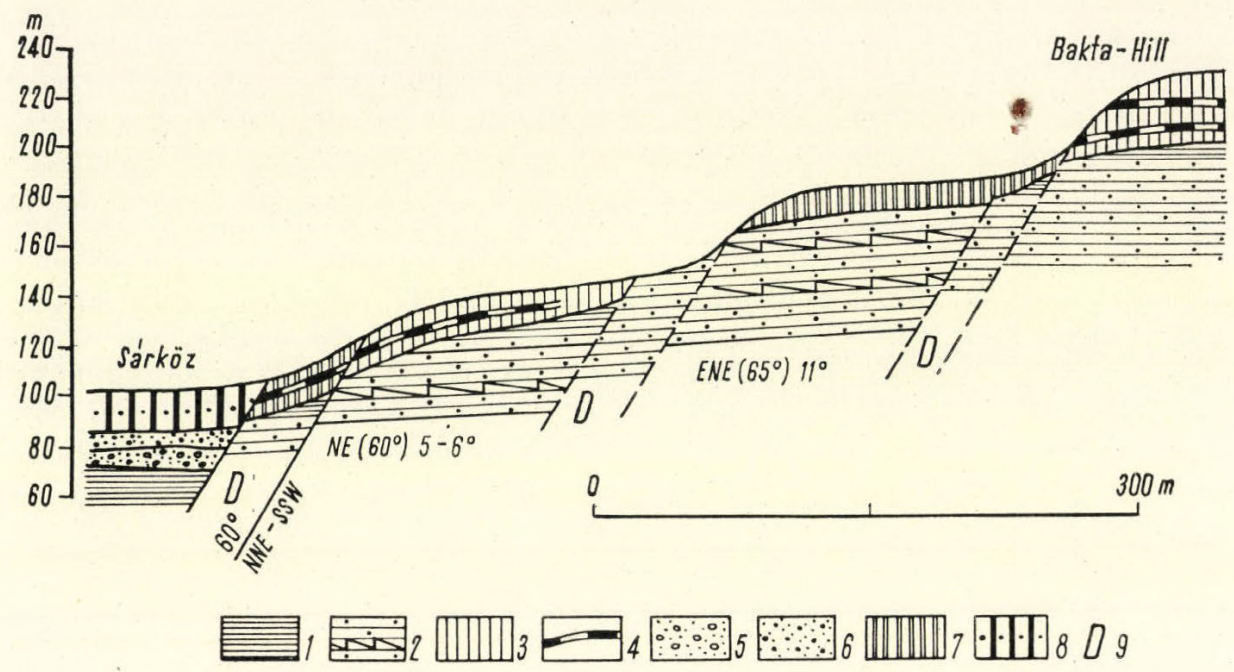

Fig. 9. Cross profiles of the eastern step-faulted border between Bakta Hill and the Sárköz. 1. Pannonian clay. 2. Pannonian sand and sandstone. 3. Typical loess. 4. Red-brown fossil soil. 5. Sandy gravel. 6. Fluvial sand. 7. Loess reworked by solifluction. 8. Deluvial sandy and silty loess. 9. Fąult, fault swarm

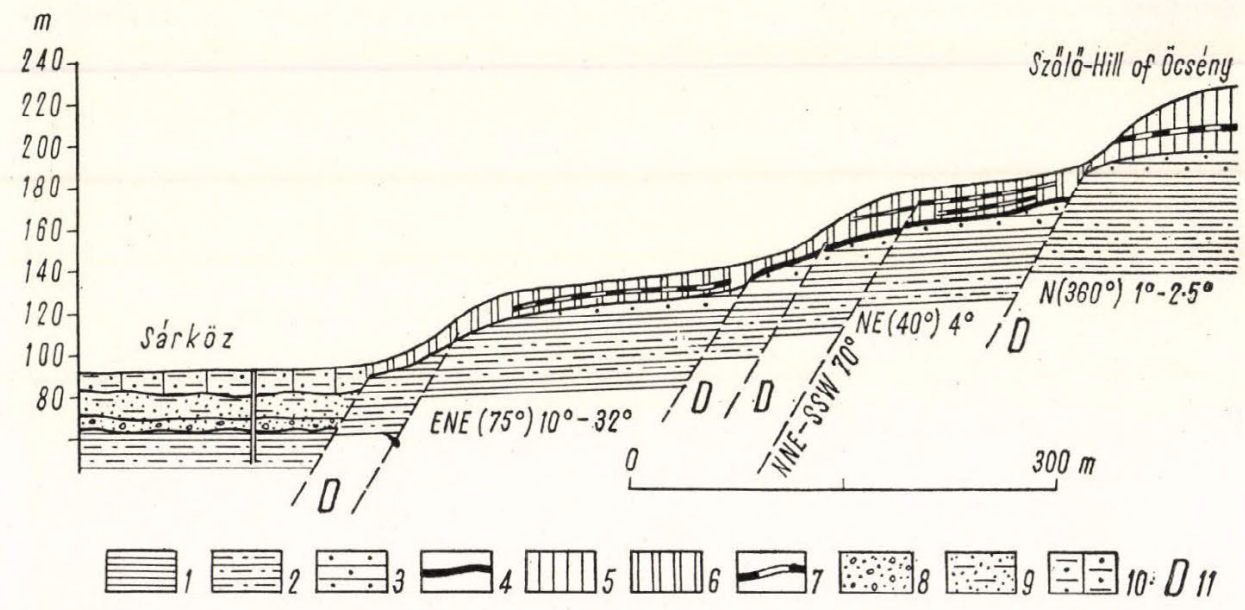

Fig. 10. Geological profile of the step-faulted border of the Szekszárd Hills between Szőlö Hill at Öcsény and the Sárköz. 1. Pannonian clay. 2. Pannonian sandy clay. 3. Pannonian sand and sandstone. 4. Fossil red clay (Lower Pleistocene). 5. Typical loess. 6. Loess reworked by solifluction. 7. Solifluidal fossil soil horizon. 8. Light grey coarse-grained gravelly fluvial sand. 9. Grey, fine-grained, silty fluvial sand. 10. Slope-washed loess, deluvial, with detritus. 11. Fault, fault swarm. 
the fossil soil horizons are dislocated irrespective of whether there are two or just one such horizons in the profile. The climax of this faulting presumably fell between Würm II and III. This was when the subsidence of the Sárköz also took place. The undissected convex decaying slopes of the step surfaces also indicate the youth of the fault steps. Except for a few loess gullies and incised dirt roads, the scarp rim is dissected neither by erosional, nor by derasional valleys.

On the other hand, the actual erosion of the soil cover of the step surfaces is a process of substantial intensity. It is largely due in these areas to intensive agriculture. The fault steps have been covered with vineyards for several centuries. Since deforestation, areal and linear erosion thus accelerated by human activity resulted in the removal of the whole soil cover in most of the area and of 75 per cent in the rest. The stepped margin is the most profoundly eroded portion of the entire Szekszárd region.

\section{FORMS DUE TO FLUVIAL EROSION AND ACCUMULATION}

Of the forms shown on the map, this group includes the alluvial plains in and about the region and various types of erosional valleys, plateau remnants sculptured by erosion, truncated valleys, terrace islands in the floodplains, and alluvial fans, all formed by the minor watercourses of the region.

\section{Erosional valleys}

The density of the valley net in the dissected and faulted Szekszárd region is high, i.e. $0 \cdot 6$ valleys per sq. $\mathrm{km}$, while 18 per cent of all valleys are erosional. An overwhelming majority of the erosional valleys follow fault lines, in keeping with the faulted structure of the region. Thus the pattern of erosional valleys reflects the fault pattern.

It is conspicuous on the morphological map that the drainage of the region is centrifugal. The erosional valleys following the fault lines radiate from the highest, central portion of the region, and reach the margin after numerous sharp turns and bends among the narrow loess ridges of various height.

Although the main factors modelling the structurally formed erosional valleys were obviously faulting and linear erosion, phenomena associated with periglacial sloping tundra, sheetwash and landslides, and slumps of various size also played a part.

On the map, the following types of valley were distinguished on the basis of morphology and evolutionary history.

a. Deep short asymmetric erosional valleys with broad straths, forming valley basins. The valleys belonging to this type possess fairly uniform structural and morphological characteristics. They alternately follow faults of NNE-SSW, WNW-ESE, E-W and NW-SE trend and their right flanks are stepped fault scarps. The faults as measured in the Pannonian strata dip $45^{\circ}$ when the strike is from NNE to SSW, $80^{\circ}$ for a NW-SE strike, and $60^{\circ}$ when the strike is from east to west. 
A further common feature is small length $(1.5$ to $3 \mathrm{~km})$ combined with great width $(1$ to $1.8 \mathrm{~km})$. The left flanks are cut into narrow ridges by derasional valleys and the forms of denudation of loess.

Valleys incised into the Pannonian had developed by the time of the Middle Pleistocene uplift of the region, and had broadened into valley basins by the time the Late Pleistocene episode of loess deposition set in. This is clearly indicated by the inclination towards the valley axis of the reddish-brown fossil soil horizons in the loesses covering the valley flanks.

In modelling the valleys, and particularly in broadening them, linear erosion was assisted to a substantial degree by periglacial solifluction, sheetwash and slumping. A considerable body of evidence concerning this point was accumulated during the evaluation of exposures in the areas (L. Ádám 1964, 1965).

The valleys, broadened into valley basins, acquired a loess cover in the Late Pleistocene, into which the rivulets deeply incised their beds in the Holocene. The valley floors were then filled with 10 to $15 \mathrm{~m}$ of loessic material mixed with reworked soil. The valleys are sculptured by soil erosion combined with sheetwash and incision. The removal several decades ago of the entire soil profile from the valley slopes is the result of human activity.

b. A quite different type of structurally formed erosional valley is encountered in the northern part of the region where there are obsequent erosional valleys (short, deep and kettle-shaped) which dissect the hummocky surface and open into the Völgység valley. Formerly of north-south direction, these valleys became obsequent after the uplift of the central part of the mountains and the graben subsidence of the Völgység valley. Profound subsidence in the graben entailed deep erosional incision in the aforementioned valleys, as revealed by shoulders on the valley flanks 20 to $25 \mathrm{~m}$ above the valley floor which were sculptured partly by late Pleistocene and partly by postglacial incision. Drainage through these valleys is rather subordinate today. Most of them do not even have perennial watercourses, and the waste derived from the valley flanks largely accumulates on the broad valley bottoms.

c. The third valley type shown on the map includes the large structurally formed valleys of some streams (Grábóc, Szálka, Alsónána valleys). These are slightly asymmetrical with perennial watercourses, following the zigzag pattern of faults of NE-SW, E-W and N-S trend. Their sculpture is largely due to linear erosion. Their evolution is marked by the retreat of the valleyheads and the destruction of the slopes. Their deep valleyheads are incised into the margin of the loess-covered Pannonian plateau of the Hármas-halom peak (295 $\mathrm{m}$ height). Most of the waste derived from the valley slopes is accumulated on the valley floors and little of it is removed.

Besides their individual traits, the valley types just described also possess a number of common features. Such common traits are great depth (70 to $150 \mathrm{~m})$ and steepness of slope $\left(15\right.$ to $\left.50^{\circ}\right)$, presumably as a result of the rapid uplift of the Szekszárd region, the lack of terraces, the breadth of straths, and the poor drainage provided by the valleys. 
Floodplain terrace islands

These are isolated landscape forms sculptured by lateral fluvial erosion on broad straths (Völgység valley) and in the wide floodplain of the Sárköz. They are particularly widespread in the Sárköz, where they were cut during the Late Holocene by the Sárviz river out of the high-flood plain surface of the Danube, capped with reworked loess. The islands consist of alluvial sand, silt and reworked loess. They are surrounded by remnants of old riverbeds which they usually dominate by 2 to $3 \mathrm{~m}$. Their surface is normally covered by a meadow-chernosem type of soil.

Terrace islands lower than $1 \mathrm{~m}$ have not been shown on the map. Such smaller islands are numerous in the Völgység and Lajvér valleys.

\section{Alluvial fans}

The rivulets of the valleys opening onto the Sárrét built flat alluvial fans on the Early Holocene terrace surface of the Danube, out of reworked loessic deposits mixed with soil derived from the interior of the region. Most of the waste accumulated in these fans came from derasional lateral valleys opening into the erosional main valleys and was removed by storm action. This highly sorted material is finely stratified and dips 1 to $3^{\circ}$ towards the Sárköz.

Between the alluvial fans of the rivulets there are smaller alluvial cones consisting of loessic material partly transported by sheetwash, and partly eroded out of gullies and incised dirt roads.

The alluvial fans of the perennial streams and the derasional alluvial fans due to sheetwash coalesced, constituting an interconnected alluvial-fan slope along the western border of the Sárköz. This slope of 2,000 ha area covers 200 million cu. $\mathrm{m}$ of reworked loessy sediment spread in a mean thickness of $10 \mathrm{~m}$. Most of it has been removed from the eastern border of the Szekszárd region since deforestation.

\section{Alluvial straths}

The term is meant here to include the floodplains of the large structurally formed erosional valleys. Their evolution is closely connected with the origin and evolution of the valleys proper. The Late Pleistocene and Holocene uplift of the hills and the subsidence of the valleys resulted in the filling-up of the valley bottoms with 10 to $20 \mathrm{~m}$ of fluvial deposits (silty and clayey alluvial sands) and loessy material washed off the slopes. This large-scale in-filling was not succeeded by any incision, and the narrow, regulated channels of the rivulets are sunk no more than $1 \mathrm{~m}$ into the alluvial surface. Hence, the alluvial straths are invariably due to accumulation and are not divided into low- and high-water flood levels. Since the gradients of the valley bottoms are very low and the rivulets in them carry little water, further filling-up is still the dominant process. The immense volume of loessic material swept out 
of the derasional valleys and washed off the slopes was deposited on the alluvial surfaces of the erosional valleys, from which only an insignificant part has been removed. After heavy rains, ground water forms stagnant pools on the poorly drained and uneven strath surfaces.

The alluvial straths cover 3,000 ha in the Szekszárd region, 1,800 ha of which is liable of waterlogging. The straths are the most important pasturelands and forage-producing areas.

\section{DERASIONAL FORMS}

This term includes the positive and negative surface forms sculptured by areal destructive processes (mass wasting, solifluction, pluvionivation, pluvial ablation), slopewash and landslides. In the sculpture of some negative forms, linear processes such as stream erosion has also played a part.

Of the negative forms, derasional valleys, derasional niches and cols are most important; of the positive forms, divides between derasional valleys, ridges, plateau remnants, forms due to solifluction and slumps should be mentioned.

\section{Derasional valleys}

These are the most typical landscape features of the entire region. On a total surface of 19,100 ha, there are more than 100 derasional valleys or about 82 per cent of all valleys.

The dry derasional valleys characteristic of our region are linear depressions of basin or saucer shape, bordered with convex and concave slopes and often lacking any level valley floor. However, this general description covers a considerable variety of forms and sizes. The most important morphological feature is the absence of any stream bed or permanent stream, and a significant broadening towards the valley head.

The derasional valleys shown on the map are classified according to morphological and topographical features. Most of these valleys came into existence in the Pleistocene but, living on through the Holocene, they are even today evolving at a considerable rate.

Their origin is revealed by the nature and geometry of the Pleistocene deposits cloaking the derasional slopes and filling the bottoms of the derasional valleys on the one hand, and by the processes of evolution observed today, on the other.

The typical saucer-shaped cross sections were formed by an interaction of areal processes (solifluction and pluvionivation) dominant during the more humid of the periglacial phases and linear erosion, which became dominant during the rainier phases of the interstadials. Today, their evolution is largely controlled by the combined influence of areal and linear erosion due to storms on the one hand and by human activity (plowing, hoeing, viticulture) on the other. Human activity is particularly harmful in the areas of viticulture. According to measurements by the author's team, the dera- 
sional slopes covered with vineyards have lost a minimum of $6 \mathrm{~m}$ of soil and sediment in the 200 to 600 years since the felling of the forest. This is proved in places by benches (pseudo-terraces) 6 to $8 \mathrm{~m}$ high, which are shown on the map, the deep derasional valleys of steep gradient have lost all the soil that once covered their slopes. As a result, their evolution-and in some cases their transformation-advances at a rapid pace. Closely spaced, they control the evolution of the surface and considerably hamper agriculture.

The short and shallow derasional valleys formed during the Holocene were not, for reasons of scale, shown on the map. The evolution and sculpture of these depends entirely on the complicated interaction of areal and linear erosion and anthropogenic factors.

\section{Derasional niches}

The derasional niches shown on the map as small roundish or oval forms usually sit above the lines of inflexion on loess slopes. They resemble loess dolines developed on a sloping surface but are open on one side. Their diameters (or lengths) are usually of the order of 50 to $60 \mathrm{~m}$.

Derasional niches are exclusively Holocene in age, their origin being due to slopewash and gully erosion, karst processes in the loess and anthropogenic factors. They are most frequent where soil erosion accompanying areal and linear erosion proceeds at a rapid rate owing to the drainage characteristics of the slope, and to the removal of the humus topsoil which has laid bare the raw loessic subsoil. Their evolution invariably begins with the erosional incision of a furrow, which broadens with further areal erosion.

The types of derasional niche shown on the map were distinguished on the basis of morphological character. The genetic differences between the individual types are insubstantial. The most that can be said is that in the evolution of the so-called double niches, human activity has played an important part. Most of these are in areas of viticulture. The upper niche from which the vineyards have retreated ends with a scarp at its upper end and hangs above the more evolved, saucer-shaped lower niche which is cultivated at present.

They are not merely accessory forms, but, owing to their frequency, they constitute together with the derasional valleys a landscape-controlling factor. In the later stages of their evolution, derasional niches change into derasional valleys. As the map shows, transitional forms are rather frequent today.

\section{Derasional cols}

These are narrow and sharp elements of transition between various forms. of the surface. They are also widespread negative forms owing to the rapid wearing away of the region. The map shows only the derasional cols of some importance. Of a variety of origins, they are most striking when separating neighbouring valleyheads, remnants of plateaux or loess divides. The evolution of derasional cols between valleyheads is largely due to headward erosion 
and slopewash. Those between plateau remnants and loess divides were largely sculptured by slopewash and solifluction, and locally by slumps.

On the derasional cols, the soil cover has invariably been removed so that at present the underlying sediment is being eroded. The slopes are usually steep and are not suitable for agriculture.

\section{Derasional divides}

The morphological map reveals the evolution of the positive forms of derasion namely divides, and plateau remnants, which are closely related to the evolution of derasional valleys. The plateaux have been so minutely dissected by various types of derasional valleys and niches and hundreds of loess gullies and incised dirt roads that all that remains is a number of derasional divides and ridges, and derasional remnants and decaying slopes.

Derasional divides are typical first of all where broad and deep derasional hanging valleys of steep gradient open into the main erosional valleys, and the slope of the divide is minutely dissected by deeply incised dry valleys. The rapid evolution of the derasional valleys has left flat rises of 120 to $150 \mathrm{~m}$ width, and even serrated loess ridges only 50 to $80 \mathrm{~m}$ wide which are rapidly enroached upon by the broadening and the rapid retreat of the valleys. The sculpture of these forms today is mainly due to slopewash and human activity.

As a consequence of intensive agriculture, soil erosion is nowhere less than 50 per cent. Indeed, in the drainage areas of the Parászta, Bartina and Csatár valleys all the fertile chernosem soil with calcareous illuvions had been eroded and for the last few decades the bare sediment has been tilled.

\section{Dlerasional plateau remnants}

As reflected by the morphological map, the narrow derasional divides ar rapidly decaying surface forms. Retreating derasional valleyheads, derasionw niches, retreating divides and deep loess gullies densely dissect the narroea ridges and cut them up into numerous derasional remnants.

Derasional remnants are forms indicating the further decay of narrow loess ridges and loess divides. They have been sculptured by periglacial solifluction, interstadial slumping, sheetwash and human activity. It is human activity that should particularly be emphasized. The unfavourable types of cultival tion, the unnecessary destruction of the forest, the maintenance for severacenturies of the wrong kinds of crop rotation and the improper use of agrotechnical practices have all assisted errosion.

Besides the derasional niches and valleys, derasional remnants are the most decisive elements of relief evolution in the region and it is by their study that the direction and rate of the dominant process can best be judged.

Rapid erosion over most of the surface is indicated by both the derasional remnants shown on the map and by the large number of remnants being modelled today. 
Plateau remnants and narrow derasional ridges combined make up approximately 5 per cent (1,000 ha) of the region. This has a number of highly unfavourable consequences: besides the erosion of the soil cover, the extent of sloping surfaces and the dissection of the relief are rapidly increasing, thus laying the foundations for a further rapid wearing away of the relief and for a successive reduction of the surface available for agriculture.

\section{PERIGLACIAL SOLIFLUCTION FORMS}

In our analysis of the genetic types of landscape features we have frequently indicated the important role played by periglacial solifluction and other surface-modelling agencies. They were particularly effective in wearing away the surface and in modelling certain complex forms.

The most durable vestiges of periglacial solifluction are sloping-tundra phenomena. Their spread is identical with the areal extent of solifluctional loesses shown on the map. On the basis of lithology and field evidence two main types of sloping tundra could be distinguished.

a. The first type mainly includes loesses reworked by solifluction which are characteristically homogeneous, and are intermixed only with the material from the fossil reddish-brown soil horizons reworked by solifluction. Fossil soils occur in this type of deposit in the form of rags and lenses of various size and thickness, and in bag-shaped kneaded-in forms resembling gravel sacks in the reworked loess (Fig. 11).

Another typical feature of loess reworked by solifluction is the shard-like or foliated texture of the material. Reworking by solifluction is clearly reflected by grain size distribution curves as well (Fig. 6).

b. The second type of sloping tundra with solifluction features is characterized by the accumulation of strongly kneaded and mixed sediments of

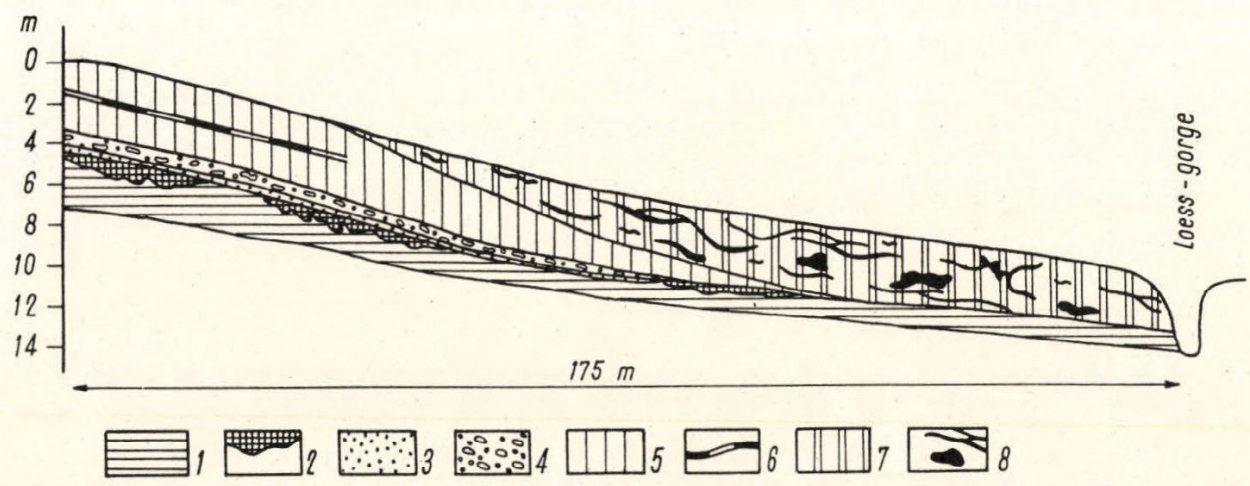

Fig. 11. Longitudinal profile of a solifluction accumulation area (sloping tundra) from the Szekszárd region. 1. Pannonian clay. 2. Solifluidal Lower Pleistocene fossil red clay. 3. Sand with detritus. 4. Bed of concretions mixed with calcareous sand. 5. Typical loess. 6. Redbrown fossil soil horizon. 7. Solifluidal loess. 8. Solifluidal fossil red-brown soil 
various lithology and grain size. The loessic matrix, reworked by solifluction, most often contains fragments of Pannonian sandstone, lumps of clay, calcareous concretions from the loess, lenses of fossil red clay and patches of calcareous material.

Sloping-tundra phenomena with solifluction are most frequent on slopes of northerly and easterly aspect.

\section{SLUMP FORMS}

The Szekszárd region is still an area of numerous landslides and slumps. In the gullies and deeply incised dirt roads, Pannonian strata slumped over each other are observed everywhere, and the threat of slumps is present in the entire area.

On the map, only slumps appearing as positive relief forms have been shown. The loess-covered convex slopes of "backs", "humps" and "mounds" are mostly the remnants of ancient Pleistocene slumps, but under certain unstable conditions, e.g. dip of the Pannonian strata, saturation with water or human intervention they might start moving again either in their entirety or partially, with small masses slumping off the main bodies. Incidentally, these old forms are sometimes exhumed by areal erosion accelerated by human intervention and regain their original shapes as the loess cover is worn away.

Their sizes are quite considerable; even the smallest ones are of 400 to 500 sq. m surface, and occupy altogether 200 ha of the region's surface.

Besides the vestiges of Pleistocene slumps, we have knowledge of a number of landslides that have recently taken place (S. Láng 1955, 1957, L. Ádám 1964, 1965). The recent landslides are, however, much smaller (usually of 50 to 80 sq. m size) than the "slump coffins" of the Pleistocene. As, however, they are the result of continuously active processes, they play an important role in the shaping of the relief even today.

\section{DEFLATION FORMS}

Of all the genetic forms shown on the map, only the loess plateaux formed by aeolian accumulation belong to this group.

\section{Loess plateaux}

The intense structural dislocation of the region precludes the existence of large-scale undissected loess plateaux. The two small plateaux shown on the map cover 2,300 ha or 11 per cent of the entire region.

A fundamental morphostructural feature of these plateaux arising from the tilt of the region, is that their surface slopes at an angle of 5 to $6^{\circ}$ towards the SSE. Another typical morphological feature is the evenness of the relief, or, more precisely, much reduced dissection as compared to the rest of the region. 
The plateaux usually bear a cloak of 20 to $30 \mathrm{~m}$ of loess, but borings have in places passed through loess successions more than 50 metres in thickness. The most typical small forms of the plateaux are loess dolines, which, however, owing to their small size (10 to $30 \mathrm{~m}$ across) and depth $(0.5$ to $2 \mathrm{~m})$ are but accessory relief elements.

The loess plateaux are the most valuable agricultural surfaces of the Szekszárd region. Covered by a chernosem soil with calcareous illuvions, and by deeply humified brown earth, they are among the least eroded areas as well.

\section{COMPOSITE GENETIC FORMS}

This group includes forms or form complexes sculptured by two or more agents i.e. structural displacement, linear fluvial erosion and processes of derasion.

\section{Erosio-derasional loess divides}

These loess-covered areas of varying width, which meander between structurally formed erosional valleys, usually carry the main divides of the region. Their sculpture was jointly performed by structural movements, linear fluvial erosion and derasion (sheetwash, solifluction and slumps, etc.). The resulting forms are together with the loess plateaux the most homogeneous in the entire region, making up 3 per cent (1,000 ha) of its area.

Their development began with the Middle Pleistocene uplift and dissection of the region and continued with the deep incision of the main structurally formed erosional valleys and with the alternating wearing away of the relief. The most remarkable morphological trait of the loess divides, which are bounded by faults on both sides, is the asymmetry of the top and of the adjacent broad slopes. This asymmetry is the result partly of structural and partly of climatic influences. This is confirmed by the tilted uplift of the individual fault blocks and by the mixed sediments reworked by solifluction on the slopes of the divides, as well as by the reworked loessic material deposited on the valley bottoms. Denudation was particularly effective on the divide slopes of southern, southeastern and eastern aspect and the consequent rapid erosion further enhanced the original structural asymmetry.

In a general way, the slopes of northern and western aspect are shorter and steeper $\left(12\right.$ to $\left.25^{\circ}\right)$ than those exposed to the south and east, whose slopes are in the 5 to $15^{\circ}$ range.

Besides alternating denudation, the slopes were also substantially in places modified by slumping. Irrespective of exposure, slumps locally reduced the steepness of the slopes; on the other hand, in some places they produced "slump coffins", having steep slopes of broken profile.

In historical times, the evolution of the loess divides has been most profoundly influenced by sheetwash and human activity. As a result of "accelerated" erosion, the divides are characterized everywhere by rounded tops and decaying convex slopes. 


\section{Erosio-derasional remnants}

These differ from derasional remnants only inasmuch as their sculpture by derasion (solifluction, sheetwash, slumps etc.) was accelerated by direct linear erosion. Indeed, in some cases linear erosion was the preponderant sculpturing agency. The remnants between erosional valleys as well as those between an erosional valley on the one side and a derasional one on the other usually belong to this group.

\section{Derasio-erosional valleys}

This is a transitional type between derasional and erosional valleys. Their topographic and other morphological features still recall valleys of derasion, but they already have a perennial stream bed with an intermittent stream in it. The transformation usually begins with the formation of a loess gully or with the surging of a spring or other seepage.

In the high-gradient derasional valleys, linear erosion and human activity result in the transformation of deeply incised dirt roads into deep and narrow loess gullies: the tapping of the underlying aquifers then results in the development of an intermittent stream on the gully bottom.

The transitional forms belonging to the groups of "deep, high-gradient hanging derasional valleys" and "derasional amphitheatral valleys" were all transformed by the opening up of loess gullies into derasio-erosional valleys. On the map, these forms are indicated by a gully drawn into the derasional feature.

The transformation of the remainder of the derasional valley types begins with the surging of a spring or of seepage water. These latter usually feed an intermittent stream in the valley.

In all types of transitional derasio-erosional valleys there are in the summer only dry streambeds or more or less wet gully floors indicating the evolutionary trend of these valleys.

Fundamentally, there is still a great deal of similarity between the derasional and the derasio-erosional valleys, the stream beds and intermittent streams in the latter notwithstanding. Among their individual morphological features, those in common are still more numerous than the distinctive ones.

\section{ANTHROPOGENIC FORMS}

This section is concerned with the relief features sculptured by various natural agencies plus human intervention. Of the anthropogenic forms shown on the map, features of loess destruction and benches (pseudo-terraces) are of some importance.

\section{Features. of loess destruction}

Besides the forms of derasion, the wide variety of this type of feature is most characteristic of the Szekszárd region, particularly in the northeast. 
The evolution and spread of these forms is intimately connected, with factors such as dissection, relief energy and precipitation and with the type of cultivation and changes in cultivation both in time and space. Areas rich in loess forms usually coincide with areas of intensive viticulture.

The most usual features of destruction include incised dirt roads, loess gorges, loess gullies, loess pyramids, loess ciques and loess dolines. Connected by various sequences of evolution, such forms substantially hamper cultivation. Their formation is largely due, to the well-developed capillarity of loess, to linear erosion, processes of suffusion (mechnical and chemical erosion) and cultivation. Karst phenomena play a subordinate role (L. Ádám 1964).

Of the loess forms, only the larger gullies and deeply incised loess roads are shown on the map. Other forms have been indicated by a common symbol according to their areal extent. In portions of the region they are so closespaced, that on a map of $1: 25,000$ scale no more than one-tenth of their number could be plotted. For instance, the 250 -hectare catchment area of the Parászta valley is furrowed by 29 incised roads, 17 gorges, 11 gullies and 6 cirques of fair size.

\section{Benches}

These forms are due to soil erosion and sheetwash, triggered by intensive viticulture. They are most typical along the borders of vineyards and other cultures such as vineyards and forest and vineyard and plowland. They are usually from 3 to $6 \mathrm{~m}$ high, but some are up to $8 \mathrm{~m}$ in height.

Benches (pseudo-terraces) are anthropogenic landscape forms which permit the reliable measurement of the depth of soil erosion "accelerated" by intensive viticulture since deforestation. The scale of the map prevented their plotting except in a few cases. They are most frequent in the drainage area of the Parászta, Bartina and Csatári valleys.

\section{ORIGIN, TYPES AND CONSISTENCY OF SLOPES}

As a result of the minute sculpturing of the region on the one hand, and of it consisting of easily eroded and poorly consolidated sediment on the other, 66 per cent $(12,700 \mathrm{ha})$ of the entire area of 19,100 ha consists of slopes, and more than 60 per cent of the slopes $(7,600 \mathrm{ha})$ have angles between 17 and $25^{\circ}$ which is highly unfavourable for agriculture.

Of the level area of 6,400 ha (34 per cent of the entire area), 15 per cent $(2,800 \mathrm{ha})$ is made up of alluvial valley floors and only $19 \mathrm{per}$ cent $(3,600 \mathrm{ha})$ of undissected elevated surfaces (loess plateaux and plateaux remnants). The situation is even more unfavourable in the light of the distribution of the land under agriculture, 71 per cent of which is on various types of slope.

The morphological mapping of slopes, which are constantly evolving and changing in both space and time, faces many difficulties and consequently cannot be carried out in full detail on a map of $1: 25,000$ scale. Although the knowledge of the evolution of the landscape features permitted us to establish 
the origin of all slopes, we could indicate slope origin only in a generalized way on the map.

The representation of slope forms posed an even more formidable problem. Firstly, irrespective of origin, the convex forms undergoing degradation and the concave features undergoing aggradation alternate rather frequently in all slope profiles, and have highly variable angles of 5 to $40^{\circ}$. Secondly, the convex and concave slopes are sometimes separated by steep plane and stepped slopes which considerably hampered surveying and mapping.

Another problem was the continual rapid shifting of slope forms on the slopes under cultivation, a process influenced by the well-known factors of lithology, slope angle, climate, vegetation, and origin and structure of the soil and also by land use, the century-old use of deleterious systems of crop rotation and the improper application of agricultural techniques.

On our map, we have distinguished between convex slopes undergoing degradation and concave slopes undergoing aggradation, leaving aside other types as being unimportant both geomorphologically and for practical purposes. The slope forms were shown on the map in a generalized way, by indicating the preponderant slope type. Since, however, convex slopes are preponderant in most of the region, whereas concave and plane slopes form a few narrow bands only, this generalization resulted in a certain underemphasizing of the latter.

The slope forms of various origin were classified as shown in the legend to the map.

\section{SLOPE GENESIS}

It follows from the overall evolutionary processes that were operative in the region as a whole that most of the slopes were modelled by erosion and derasion.

\section{a. Erosio-derasional slopes}

This type includes first of all the slopes of erosional valleys whose sculpture was primarily due to linear erosion.

The uplift of the region and the simultaneous incision of the creeks and rivulets resulted in slope modelling by both retreating and lateral erosion.

Besides linear erosion, however, the slopes of erosional valleys were also actively modelled by derasion as shown on our map.

In the broadening and subsequent sculpturing of the valleys as well as in the simultaneous wearing away of the slopes, areal processes played the main role. Evidences of this are the phenomena of periglacial sloping tundras, redeposited deluvial loessic sediments, small-scale slumping and the alternating convex and concave sections in the slope profiles. Erosio-derasional slopes include also the steep slopes densely furrowed by loess gullies and incised dirt roads. 


\section{b. Derasional slopes}

The slopes of derasional valleys and of all positive derasional forms were largely modelled by alternating processes of areal derasion. In respect of derasional valleys, the slope-modelling role of gelisolifluction must be particularly emphasized, whereas the sculpture of the slopes of positive derasional forms was largely due to slopewash. Derasional slopes are presently evolving largely under the influence of human activity and slopewash, including soil erosion.

\section{c. Derasional remodelling of broken slopes}

Structural movements have played the main role in forming the slopes of the eastern and northern border of the region. The fault steps naturally resulted in primary scarp slopes, which were, however, profoundly remodelled by alternating denudation during the Pleistocene. Alternating denudation comprised processes of periglacial solifluction, slumping and sheetwash. As revealed by the map, solifluction was the dominant process. By wearing away the step surfaces, it sometimes increased the steepness of the primary scarp slopes, while some of the steep slopes still reflect the underlying structure.

In historical times, slope sculpture has been largely due to intensive agriculture.

\section{SLOPE FORMS}

The slopes of various origin, enumerated above, consist mainly of convex and concave elements, the first undergoing degradation and the latter undergoing aggradation.

\section{a. Convex slopes}

70 per cent $(8,800 \mathrm{ha})$ of slopes covering a total area of $127 \mathrm{sq} . \mathrm{km}$ are convex. Except for the derasional valleys, this is the dominant slope form of all relief features. The formation and wide extent of convex slopes is due to the considerable relief energy of the region, profound vertical dissection, slow uplift and denudation "accelerated" by human activity. Degradation of convex slopes is most widespread on the broad upper tracts of erosional valleys, on the loess divides spared by denudation, on the narrow derasional interfluvial ridges and on the large-size landslides.

The degradation of the convex slopes is at a fairly advanced stage in all of the above-mentioned cases. On most of them, the slope profile is totally eroded and on the rest by 75 per cent or more. The depth of erosion is also a function of slope angle and soil type. Slopes in the range of 15 to $30^{\circ}$ and those with angles above $30^{\circ}$, which are distinguished on the map, are almost 
exclusively convex. Their surfaces are furrowed by rain rills, erosional gullies, incised dirt roads and loess gorges.

On the convex slopes, agriculture has for some decades been carried on on the present bed-rock.

\section{b. Concave slopes}

For reasons of scale, less than 50 per cent of all concave slopes are shown on the map, because the concave sections usually occur in narrow bands of 10 to $30 \mathrm{~m}$ width and are intermixed with convex sections. Concave slopes make up an estimated 20 per cent $(2,500 \mathrm{ha})$ of all slopes, and are most frequent on derasional slopes, on scarp slopes modified by derasion and to a smaller extent on erosional slopes.

The concave slope sections are aggraded mainly with redeposited loessic sediment, and have average slope angles of between 3 and $15^{\circ}$. However, owing to the vertical raggedness of the relief and to the steepness of some slopes, not all concave slopes are being aggraded.

\section{c. Plane slopes}

The generalization of slopes on the map has meant that plane slope sections could not be distinguished at all, for the same reason of scale as was invoked in connexion with the concave slopes. Plane slopes make up somewhat less than 10 per cent (1,200 ha) of all slopes, forming narrow bands in steep and deep derasional valleys and on scarp slopes modified by derasion.

The plane slopes generally have average angles greater than $30^{\circ}$ and are almost exclusively being degraded. Intensive viticulture resulted in erosion down to the underlying sediment, and the surfaces furrowed by gullies are entirely unsuited for agricultural exploitation.

\section{THE CHRONOLOGY OF LANDSCAPE FEATURES}

The age of genetic landscape features is indicated by a letter code on the map. The dating of the forms was based upon stratigraphic, structural, morphological, evolutionary, palaeoclimatological, pedological and historical evidence. The relevant data were listed in detail by Ádám (1964 and 1965).

In dating features we were fully aware of the dynamic nature of most elements and the fact that their formation covers more than one stratigraphic time unit. For instance, the evolution of the elluvial-fan slope bordering the Sárköz on the west began as early as the Late Pleistocene, and has been going on up to this day, with maximum impetus during the early Holocene. This continuous evolution through several stratigraphic units is indicated by the triple symbol $\mathrm{Q}_{3}-\mathrm{H}-\mathrm{H}_{3}$.

Some other forms have been continually eroded ever since their origin, and such negative changes cannot, of course, be dated. Accordingly, the age for example of a loess plateau formed at the time of the uplift and dissection of 
the region and the simultaneous accumulation of loess is indicated by the simple symbol $\left(\mathrm{Q}_{3}\right)$.

For reasons of scale, no symbols were attached to small features such as loess forms, slumps, derasional valleys, niches, cols, and valley shoulders, etc. Of these, the steep and deep derasional valleys are Late Pleistocene to Holocene in age, while those that are flat basin-shaped are Holocene. Most slumps are Late Pleistocene, but some are Early and Late Holocene. Loess features (incised dirt roads, gullies, etc.), derasional niches and anthropogenic forms are exclusively recent.

\section{OUTLINE AND RATES OF RELIEF EVOLUTION}

With a knowledge of the geohistorical evolution of the region, the form types constituting the relief and of the actual processes of landscape modelling, an outline history of relief evolution and an estimate of rates of evolution can be made. With this knowledge of the past and present state of the relief, one can make a scientific prediction concerning its future.

The evolution of the Szekszárd region is dominated by the continued modelling of derasional and erosional forms, by the inception of such forms and by the slow uplift of the region.

The most effective factors in relief evolution are the derasional valleys and niches. Over an area of $191 \mathrm{sq} . \mathrm{km}$, there are 95 of the first and 113 of the second. All of the widely different types and stages of negative derasional forms are undergoing rapid evolution, owing to areal and linear erosion accelerated by human activity. The retreat of valleys and niches is as rapid as their broadening, which results in a steepening of the valley slopes. Slopes greater than $20^{\circ}$ are lost to agriculture. Quite a large number of derasional valleys have already attained this stage, and their broad valley flanks have become barren lands.

The above process and the simultaneous formation of new derasional niches and lateral valleys on the steep derasional valley slopes and adjacent gentler slope elements results in the rapid dissection of the divides between the main derasional valleys.

On the other hand, the deepening of the high-gradient derasional valleys and the concurrent human activities results in gully formation on the valley floors with the concomitant tapping of subsurface aquifers and the transformation of derasional valleys into erosio-derasional forms. This process results in the loss of increasing tracts of land to agriculture annually.

The evolution of erosional valleys follows very much the same pattern, except that the area withdrawn from agriculture is substantially larger. It involves first of all the decay and steepening of the broad arable valley slopes, which increases the number of derasional side valleys, derasional remnants, incised dirt roads and gullies and accelerates the erosion of the topsoil and the dissection of the slopes.

Since 71 per cent of the agricultural area of the Szekszárd region consists of slopes of one kind or another, the above-outlined process of evolution bodes ill for the prosperity of the region. 
Besides the derasional forms, the features of loess destruction also prove that the evolution of the relief is heading in an unfavourable direction. Their wide extent proves that soil erosion as a result of both linear and areal erosion has already progressed a long way.

The incised dirt roads crisscrossing the loess divides, ridges and slopes develop into gullies and gorges (10 to 15 per cent of all incised dirt roads undergo this transformation annually), and as soon as the more developed gorges strike the underlying Pannonian, they become erosional valleys with perennial watercourses. This process is continuous and rapid, and the concomitant soil erosion may attain catastrophic proportions. Gullies 20 to $25 \mathrm{~m}$ deep are known to have formed in the last 50 to 80 years.

The palaeogeographical evolution and the present trends of change in the relief suggest that this slowly rising hill region will continue to decay under the processes of derasion and erosion. New valleys are being continuously formed and the older features are constantly evolving. The evolution and transformation of loess forms are no less incessant, and soil erosion still goes on.

The rate of valley evolution, particularly of retreat, will presumably increase in the future, because in this asymmetrically uplifted region the valleyheads retreat into ever more elevated surfaces, thus steepening the longitudinal valley profiles. Simultaneously, the rapid broadening of the valleys will result in the dissection of the interfluvial divides into narrow ridges and remnants.

The above-outlined processes and the acceleration of the evolution of loess forms will inevitably lead to the full destruction of the soil cover, and to an even more intense dissection and wearing away of the relief. This process is at the time of writing so far advanced that failure to take effective countermeasures may within a few decades make agriculture impossible in most of the region.

\section{METHOD}

Mapping in the field was preceded by a thorough geological and morphological analysis of the region.

Getting acquainted with the geology and structure of the region took several field trips, during which the numerous exposures were all surveyed and evaluated. The dense network of deep valleys and the gullies on the valley bottoms expose the entire succession of strata down to the Upper Pannonian. Evidence thus accumulated was complemented with borehole $\operatorname{logs}$, and presented in the form of a geological profile. Dips measured in the Pannonian deposits exposed in the deep gullies were used to draw up a detailed picture of the structure and to establish the correlations between structure and morphology.

Concurrently with the stratigraphic survey, the surface deposits were mapped at a scale of $1: 25,000$ which meant in essence the revision of an earlier geological map of the same scale. Particular attention was given to distinguishing and mapping the various types of reworked loess, Pannonian deposits and fossil red clays.

Subsequent field trips were dedicated to a thorough genetic analysis of the land forms of the region. This analysis was performed according to form 
groups, and included first of all the clarification of the complicated interactions between the natural agencies modelling the relief. Emphasis was placed on the modelling effect of human activity which largely means agriculture in the present case and which has been neglected in the past.

Detailed analysis was invariably carried out where the feature under study was most typical. Subsequently, features were classified by topography, origin and morphology (e.g. types of erosional valleys, types of derasional valleys, etc.) and given suitable descriptions. Analysis included a number of painstaking measurements in the field and in the laboratory, such as measurements concerning soil erosion during storms in order to gain insight into the rate and nature of slope evolution and into the processes sculpturing the dry valleys, the mapping of various forms (forms of loess erosion, benches) and of correlate deposits in order to characterize numerically the rates of erosion of past times, etc. Moreover, we measured the discharges of watercourses in the erosional valleys and studied experimentally the water capacity of several ecological types in several drainage areas.

Work in the laboratory was aimed at distinguishing the various types of deluvial loessic sediment and at clarifying the origin of some of the landscape forms. Techniques included the grain size analysis of typical loesses, loessic deposits and sands, the assaying of the $\mathrm{CaCO}_{3}$ content of loesses and related deposits and the DT analysis of fossil red clays.

Stratigraphical, structural and morphological analysis and the evaluation of the relevant literature permitted us to outline the evolutionary history of the region and to correlate it precisely with the evolution of neighbouring microregions.

It was only after the completion of these activities that the detailed morphological mapping of the microregion was begun. It involved a third set of field trips which were also used to carry out pedogenetic and soil erosion mapping. The most important task during this phase was to map the morphological elements with the least possible distortion. The actual drawing of the map was done on a transparent sheet stretched over a topographic map. Another main task was the morphologic mapping of the slopes. Having previously established the origin and evolution of the slopes, this meant the fixing of slope forms, angles, consistency and stability, based among other things on 1,300 borings and soilprofile measurements performed in connexion with soilerosion mapping.

After this mapping in the field, the geomorphological map was constructed as follows. The lithological base was generalized in keeping with the scale of the map. The several varieties of reworked deluvial loessic sediments were grouped under the two heads of solifluctional and slopewashed types; the type directly underlying the soil profile was invariably indicated as the base. The varieties of Pannonian deposits were also subsumed under two headings, as shown on the map. A similar simple grouping of alluvial deposits was likewise performed.

Although it was our aim to represent to scale all morphogenetic forms, this undertaking, which was successful for large forms, was unsatisfactory for the dense scatter of small forms. Thus for example loess destruction features and benches were indicated, with the exception of the largest loess gullies and 
most striking incised dirt roads, by comprehensive symbols which simply mean that the form symbolized is frequent in the area covered by the symbol. Even so, close-spaced small derasional niches, cols, plateau remnants and slumps could not be plotted at all. A similar generalization was also resorted to when showing slope types. Slope angles were derived partly from measurements, and partly from the 10-metre contours of the topographic map sheet.

\section{REFERENCES}

Ádám, L, Marosi, S. and Szilárd, J. (1959): A Mezőföld geomorfológiai térképe (A geomorphological map of the Mezôföld). Földrajzi monográfiák II, Budapest: Akadémiai Kiadó.

Ádám, L. (1960): A tolnai Hegyhát kialakulása (The evolution of the Hegyhát region in Tolna County). Földrajzi Értesitő, Vol. 9. 143-176.

Ádám, L. (1964): A szekszárdi dombvidék kialakulása és morfológiája (The evolution and morphology of the Szekszárd region). Földrajzi Tanulmányok 2, Budapest: Akadémiai Kiadó.

Bartha, F. (1956): A tabi pannoniai korú fauna (The Pannonian fauna of Tab). MÁFI É könys, Vol. 45. pp 481-579.

Bendefy, L. (1956): Szintezési alappontok időközi magasságának meghatározása (How to determine the altitude variations of high-order levelling bases). Geofizikai Közlemények, Vol. 6. pp 72-89.

Borsy, Z. (1961): A Nyírség geomorfológiai térképe (A geomorphological map of the Nyírség). Földrajzi Monográfiák 5, Budapest: Akadémiai Kiadó.

Bulla, B. (1936): Terraszok és szintek a Duna jobb partján Dunaadony és Mohács között (Terraces and levels on the right bank of the Danube between Dunaadony and Mohács). Math. és Term. Tud. Ért. IV, pp 193-224.

Kadic, O. (1917-1923): Szekszárd, Tevel és Bonyhád vidékének földtani viszonyai (The geology of the Szekszárd-Tevel-Bonyhád region). Földtani Intézet Êvi Jel. pp 89-93.

Kriván, P. (1960): A Duna ártéri szinlooinek kronológiája (The chronology of the floodplain levels of the Danube). Földtani Közlöny, Vol. 90. pp 56-71.

Láng, S. (1955): Geomorfológiai megfigyelések a Szekszárdi-dombvidéken (Geomorphological observations in the Szekszárd region). Földrajzi Közlemények, Vol. 3. pp 151-155 (new series).

Láng, S. (1957): Természeti földrajzi tanulmányok a Sárköz környékén (Physiographic studies in and around the Sárköz). Földrajzi Értesitố, Vol. 6, pp 137-154.

Leél-Össy, S. (1953): Geomorfológiai megfigyelések Baja és Bátaszék vidékén (Geomorphological observations around Baja and Bátaszék). Földrajzi Közlemények, Vol. 1. pp 101-114 (new series).

Lörenthey, I. (1892-1894): A szekszárdi, nagymányoki és árpádi felsőpontusi lerakódások és faunájuk (The Upper Pontian deposits of Szekszárd, Nagymányok and Árpád and their fauna). Földtani Intézet Évkönyve, pp 67-142.

Pataki, J. (1955): A Sárköz természeti földrajza (The physiography of the Sárköz). Szekszárd

Pataki, J. (1960): A mezőgazdálkodás felszínformáló hatása a Szekszárdi-dombvidéken (Modelling of the relief by agriculture in the Szekszárd region). MTA Dunántúli TI. É könyve, pp 55-92.

Pécsi, M. (1959): A magyarországi Dúna-pölgy kialakulàsa és felszinalaktana (The evolution and morphology of the Hungarian section of the Danube valley). Budapest: Akadémiai Kiadó.

Pécsi, M. (1959): A Duna-völgy magyarországi szakaszának geomorfológiai térképe (A geomorphological map of the Hungarian section of the Danube valley). Földrajzi Monográfiák 3, Budapest: Akadémiai Kiadó.

Pécsi, M. (1963): A magyarországi geomorfológiai térképezés az elmélet és a gyakorlat szolgálatában (Geomorphological mapping in Hungary and its emphiations for theory and practice). Földrajzi Közlemények, Vol. 11, pp 289-299 (new series).

Sédi, K. (1943): A Sárköz morfológiája (The morphology of the Sárköz). Földrajzi Közlemények, Vol. 71, pp 111-123. 
Strausz, L. (1952): Adatok a dunántúli neogén tektonikájához (Contributions to the knowledge of Neogene tectonism in Transdanubia). Földtani Közlöny, Vol. 82, pp 40-52.

Strausz, L. (1952): A Dunántúl DK-i részének földtani felépítése (The geology of Southeastern Transdanubia). Földrajzi Értesitö, Vol. 1. pp 219-250.

Sümeghy, J. (1952): Hidrológiai szakértői vélemény Szekszárd város új víztermelő telepe létesítéséről (Expert opinion concerning the new waterworks at the town of Szekszárd). Hidrológiai Közlöny 1-2, Vol. 32, pp 20-24.

Sümeghy, J. (1953): A magyarországi pleisztocén összefoglaló ismertetése (A comprehensive review of the Hungarian Pleistocene). MÁFI Évi Jel., Vol. 41, pp 395-403.

Symbols used on the detailed geomorphological map of Hungary. Publ. by physiographic research group of the Geographical Institute of the Hungarian Academy of Sciences, Budapest, 1963.

Szabó, J. (1863): Szekszárd környékének földtani leírása (Geological description of the environment of Szekszárd). A Magyar Földtani Társulat Munkálatai II.

Szabó, P. Z. (1957): Délkelet-Dunántúl felszínfejlődési kérdése (The relief-evolution problem raised by Southeastern Transdanubia). Földrajzi Értesitô 4, Vol. 6, pp 397-419.

Toborffy, G. (1920-1923): Jelentés az 1921-23. években Tolna megye területén végzett részletes geológiai felvételrôl (Report on the detailed geological mapping in Tolna County, 1921-1923). Földtani Int. Evi Jel. pp 94-100.

Vigh, Gy. (1942): A földtan szerepe a városok vízellátásában (The role of geology in the water supply of towns). Hidrológiai Közlöny, Vol. 22. pp 145-176. 



\section{MICROCLIMATOLOGICAL INVESTIGATIONS WITHIN THE SCOPE OF COMPLEX PHYSIOGRAPHIC LANDSCAPE RESEARCH IN HUNGARY}

by

P. JAKUCS, S. MAROSI AND J. SZILÅR

\section{NEW PHYSIOGRAPHIC RESEARCH METHODS IN HUNGARY}

During the past fifteen years considerable research concerning the physical geography of the plains and hilly and mountainous regions of Hungary has been undertaken which is reflected in the large number of publications that have appeared. Earlier, individual workers were engaged in general physiographic problems such as terrace morphology, valley evolution and periglacial morphology as well as being concerned with the systematic branches of geomorphology, climatology, hydrology and phyto and soil geography. In the last decade, however, special attention has been given to landscape research, although at first only the geomorphological factors were investigated through original research. The data for other relevant parameters was borrowed from related disciplines and even then was used in an encyclopedic and ancillary manner. Consequently, there was little possibility to study and evaluate the multiple relations and correlations between all the natural factors producing the landscape. The increasing practical demands placed on geography, however, made it necessary to undertake more thorough studies, which have involved the introduction of new techniques and the opening up of new research fields. At the same time, the development of a geographical research organisation made at all this possible, and as a result, considerable progress has been made in thematic physiographic mapping and in landscape evaluation (Marosi and Szilárd 1967).

These two fields are closely connected as regards both aim and research techniques. Physiographic mapping, at first, was based on a general and later a detailed geomorphological survey of Hungary. During the last few years it has been extended to include the preparation of other special maps showing the hydrology, vegetation, soil types, soil erosion and slope categories of the country. Prognosis maps for engineering geology, economic geology, and foreign and domestic tourist traffic have been constructed, while a start has also been made: in the field of microclimatological mapping. An explanatory text is added to every map.

Landscape evaluation is closely connected with and relies on thematic physiographic mapping, and is considered a new branch of applied geography. Its aim is to summarise the favourable and unfavourable environmental factors which influence the economy providing us with a map of 'landscape potential' (Marosi and Szilárd 1964). The reliance on maps does not imply the ommission of analytical research since landscape evaluation relies on the results of such work being produced in map form. Indeed, by bringing together all relevant information, it results in a high standard of landscape synthesis. 
The main task of landscape evaluation is to detect and to delimit spatially natural condition influencing the economy as well as characterising their multiple interrelationships. Its basic areal unit is the ecopottype which differs from the spatial units of traditional landscape research (ecotype and facies, etc.) in corresponding manner to the functional contrasts outlined below.

The aim of landscape research is to investigate and to detect the complex relationships between natural landscape factors. On the other hand, because of its practical orientation, landscape evaluation sets out to demonstrate the ways in which the natural environment can be utilized from the economic point of view.

Much of the practical work is common to the two. Landscape typological studies are an important feature of landscape evaluation, both using the same fundamental spatial units which are choosen on the basis of homogeneity or at least quasi-homogeneity of all factors influencing the natural environment. Landscape evaluation provides a practical estimation of the economic potential of these homogeneous landscape units.

In order to detect the fundamental units of landscape research and landscape evaluation a convenient starting point is to adopt the realistic assumption that their character is determined by one natural factor which is either dominant, or, at least, reflects other operative factors. For the detection and appreciation of this decisive natural factor extensive field work must be carried out. Often crude information is sufficient to permit the preliminary identification of this factor in a given case, but its detailed re-investigation is an important step in landscape evaluation. In many cases it may be the macro-and microrelief, the natural vegetation or the soil conditions, which require more detailed study in an already explored area in order to permit the characterization of the natural landscape.

In the course of current detailed landscape research the authors became aware of the fact that both the individual and collective significance of landscape factors is reflected by the microclimates of small areas. This characteristic is independent of both the dominant factor and the inter-relationships between factors which determine particular landscape types. In other words, microclimate is a very sensitive indicator of the character of complex landscapes.

\section{THE SIGNIFICANCE OF MICROCLIMATOLOGICAL RESEARCH}

The perception of the relationship described above has motivated microclimatological research work. In the course of this objective data have been obtained through accurate observation. These facts as effects promote the knowledge of their causes. It is often possible by investigating a certain natural agent to draw conclusions about other factors, and so achieve a complete synthesis, because of the regular interrelations (co-variance) between these factors.

The relationships between the surface substrate and the atmosphere are regular and interwoven, and are primarily a function of distance. With increasing distance from the earth's surface, the influence of the surface, soil and 
vegetation on the atmosphere and of the atmosphere on the surface, etc. steadily decreases. The effect of the surface substrate is felt directly up to a height of 2 metres which is the effective upper limit of the microclimate, although, depending on the nature of a given surface, this may be as low as 1 metre.

The degree of efficiency varies not only spatially but also in time and is a function of the macroclimate. Since microclimate is an important determinant of the smallest landscape elements, i.e. of the fundamental units of landscape research and landscape evaluation, microclimatological research is indispensable. This has been confirmed over the past few years by the landscape research undertaken by the present authors.

A few concrete examples will be discussed below.

\section{LANDSCAPE CLASSIFICATION TYPES BASED ON MICROCLIMATOLOGICAL RESEARCH}

In the course of landscape research, microclimatological investigations were carried out in the three fundamental morphological and physical regions of Hungary, namely, the plains, the hill regions, and the mountain areas of medium height. Within these, small areas, considered to be type localities, were recognized, the characteristics of which can be generalized and extended to larger regions of similar natural conditions.

The classification, elaboration and comparative study of data compiled from several tens of thousands of systematic observations over a period of two years, enabled the authors to recognize several special microclimatic types within these three basic physical regions. This programme, along with the determination of other landscape factors, made possible a multivariate physico-geographical characterization and economic evaluation of each type.

The present paper is not the place to discuss the detailed results of the investigations or the place to provide a thorough description of each locality and their spatial extent. The aim is rather to give a general and at the same time characteristic description of each type group (numbered 1, 2, 3, etc.) and of each type (denoted a, b, c, and so on).

The significance of the present study lies in the fact that no microclimatological investigations of this kind have been undertaken before in the context of physico-geographical research other than by the authors of this paper. During the last decade particularly, a considerable number of microclimatological studies have been carried out in different environmental areas in Hungary. However, in most cases, these have been either in the field of plant ecology which is strictly dependent on the local climate, or have been concerned with the physical characteristics of the near-surface air layer, such as its circulation and dynamic properties. Consequently, most climatological studies were performed by students in related sciences, chiefly by botanists and climatologists whose scientific and practical aims were limited by the boundaries of their own disciplines. Since each of these studies was either carried out or directed by a single expert no multivariate synthesis of the relationships between microclimate and landscape factors was attempted. Notwithstand- 
ing, the results of these studies can be very useful to geographers, if evaluated critically. (See references.)

\section{A. INVESTIGATIONS ON THE PLAINS}

More than half of Hungary, about 50,000 square kilometers, consists of relatively flat plain land, which varies, in height from 100 to $200 \mathrm{~m}$ above sea level, although locally it may be somewhat higher, while relief energy is less than $30 \mathrm{~m}$ per square kilometer. This does not mean, however, that such areas are monotonous.

The lowest areas are between 75 and $100 \mathrm{~m}$ above sea level and comprise riverside plains, characterized by an assemblage of irregular, abandoned, cutoff and stagnant riverbeds, low terraces and floodplains. Depending on the level of the ground water table and surface water conditions, a height difference of a few decimeters results, in a remarkable variety of vegetation, soil and microclimatic types, hydromorphic soils (meadow and bog varieties) alternating with a variegated assemblage of sodic soils.

Pleistocene talus surfaces, covered at present by blown-sand, loess and loesstype sediments, make up the higher parts between 120 and $170 \mathrm{~m}$ above sea level. On these, chernozem grassland soils are dominant, although skeletal soils and soils in the initial stage of formation occur on the blown-sand, while in areas of more abundant precipitation forest soils are of significance. Many small features occur in the areas above the floodplains, especially on the blown-sand surfaces, and the relief energy in these areas is higher. Interesting microclimatological relationships and different type varieties are also to be discerned on the plain surfaces. But since the effects of cultivation are strongest here natural vegetation being scarcely represented varieties of plant stand climate predominate which suppress the natural climatic conditions. Blown-sand surfaces exhibit extreme features, and some restricted areas still represent quasi-natural conditions.

The most extreme types discovered during the investigations in the plain areas are found on sandy surfaces whose physiographic properties are unique.

In Hungary sandy surfaces of both high and low relief energy are to be distinguished, with a wide range of transitions. Large areas of the country are sandy and include the Danube-Tisza Interfluve, Dél (South) Mezóföld and the Belső (Inner) Somogy regions. The lowest relief energy is found on the sand surface of the Belsô Somogy, because of its age its more westerly and therefore humid climate and "closed" cover vegetation.

The series of microclimate measurements made by the authors embraces the most characteristic types of Hungary's extensive sand areas. On the basis of the general climatic picture the regularities found may be extended to other areas of similar topography and vegetation, and to microclimates associated with identical substrates.

The following microclimatic type groups have been distinguished on the non-cultivated sand surfaces which are dependent upon the topography, lithology, soil, groundwater and vegetation:

Type group 1. occurs in areas of continuous vegetation cover which are moderately cool and wet. These microclimates are generally characterized by 
temperatures of moderate maxima and minima, gradual of warming and cooling gradients, comparatively high moisture content and diminished wind action.

In this case the factors directly influencing the microclimate are vegetation and soil, which produce two distinct types:

a. A closed, comparatively wet marsh and bog type of meadow and sedge.

b. A closed, forest type, with leaf cover.

Type group 2. occurs in areas covered by "open" (discontinuous) sand"puszta" grass, which are warm, dry and extreme. These types are characterized in general by a wide daily temperature range (cool minima and warm maxima), irregular warming and cooling curves, comparatively low moisture content and vigorous wind action.

The agents directly influencing the microclimate are topography and lithology which produce four types:

a. sand steppe grass on the sand-hills of the plan whose summits are exposed to winds from all directions;

b. steppe grasses on slopes in areas exposed to intense insolation, and winds from one direction only. A further subdivision can be made on the basis of slope disposition and at effect on insolation. Because the long axes of these sand dunes are from north to south, west and east slopes predominate, and slopes facing north and south are subordinate and of much smaller surface area. Therefore there is but a time difference corresponding to the $\mathrm{E}-\mathrm{W}$ movement of the sun, the slope facets on approximately equal insolation, which thus belongs to the same type.

c. A plain hollow, protected from the winds by the topography, which has an extreme microclimate.

d. A wind-made furrow. In many respects this type is transitional between type groups 1 and 2 . In the lower parts of the furrow the microclimate is similar to the former, and in upper parts to the latter. Its special features are due to its morphological character, since it is delimited by slopes on two sides and open on the other two.

On the basis of ecological investigations carried out by the authors on quasi-natural surfaces, several proposals of practical importance can be made, which may be extended to other sandy areas of similar high relief energy.

Forest is the natural vegetation of the cooler and wetter sandy areas of Hungary, where only the most exposed, dry and warm sand-hill slopes are covered by partly open grove forests or by a mosaic of sand steppe grass. The latter vegetation is characteristic of the greater part of the warmer and drier sand surfaces in the Danube-Tisza Interfluve and in the DélMezöföld. The sand and the topography in some parts of the Nyírség and Inner Somogy result in extreme microclimates of subcontinental character which exist within the Central European subatlantic and submediterranean climatic regions. The recent sand-puszta grasses may be considered remnants of much more extensive areas which occurred during the postglacial hazelnut phase. In these areas, continental plant species which can endure extreme ecological conditions, are still to be found in considerable number.

It may be concluded that the afforestation of these small steppe areas would be a difficult task. Other forms of economic utilization would not be profitable 
either, because one has to deal with sporadically distributed small areas on which large-scale farming is not possible. Expensive reclamation would only be rewarded in the distant future. Assuming reclamation, however, such areas could be utilized for highly developed vineyard- and orchard-cultures as has been done on the sand areas between the rivers Danube and Tisza. Sporadic planting of fruit-trees in areas where ground water lies close to the surface can be considered even now.

The economic utilization of sand steppe grasses is hindered by the fact that areas exposed to denudation have already lost their soil cover and bare sand or a thin sandy skeletal soil of low humus content is present. Pasturing only results in further soil destruction.

The deep wind-made furrows, the valley floors, and plain surfaces produced by both erosion and deflation are always areas of wetter and cooler ecology because the groundwater table has close to the surface. During the atlantic phase of the Holocene such areas were covered by closed forest. In the shallow hollows on the cooler sands areas where the groundwater table was some distance below the surface, mixed forest of elm, oak with some hornbeam dominated. On the other hand, in the deeper depressions, which were either covered by water during part of the year, or had a constantly high groundwater level, elder-ash associations occurred. With deforestation such areas were overgrown by sedge or by marshy meadow associations.

Low lying surfaces of both types can be afforested after appropriate preparation, and their economic value can thus be increased. It is important to drain such areas where the groundwater table is too high. In level areas of lower groundwater table, cultivation of hoed plants and kitchen-garden vegetables may be recommended, while fish ponds can be established in closed and deep depressions. Here conditions for fish breeding can be improved by further deeping of the depression or by dam construction, where a larger catchment area is necessary. The water in the fish ponds can be used for irrigation for the afforestation of drier surfaces and for other branches of intensive farming. These depressions may also be used for the breeding of water fowl.

Type group 3. occupies sand areas of low relief energy. The microclimates, ecotypes (facies), and ecopottypes are more extensive spatially and less diversified vertically, which makes their economic utilization much easier. The best example of this in Hungary is the intensive agricultural utilization of the sandy area between the rivers Danube and Tisza, with its rich viti- and orchard culture. Here reclaimation started after the phylloxera plague devastated the country's historical mountainous wine-districts.

Microclimatological investigations carried out on sand surfaces of identical height, lithology, soil, and ground-water table, but with varied vegetation cover confirmed that a single natural feature or landscape factor, in this case vegetation produces essentially different microclimates. That is, the decisive factor determining the climate on surfaces of otherwise identical ecology is the plant stand itself. Of course, this develops and changes with time, effecting its own climate, which, in its turn, now and then reacts upon the development of the stand. 


\section{B. INVESTIGATIONS IN HILLY AREAS}

Most of Hungary's hilly regions are situated in Transdanubia. Although a small area lies on the border of the Northern Central Mountains. Their principal characteristic features are: a height usually not exceeding $300 \mathrm{~m}$ a.s.l. relief energy values ranging from 20 to $150 \mathrm{~m}$ per square $\mathrm{km}$, and, particularly in South Transdanubia, a system of north-south longitudinal valleys and northwest-southeast or southwest-northeast transverse valleys, with intervening ridges and crests. The slopes of the N-S and NW-SE oriented valleys and ridges which are perpendicular to the strike of the Hungarian Central Mountains, are generally either symmetrical or slightly asymmetrical. In contrast, the valley slopes parallel to the Central Mountains, are characterized by wellmarked asymmetry. The north facing slopes are high and steep, while those facing south are lower and gently sloping.

The hilly surfaces are generally built up of loose marine and in-land lake sediments, but outcrops are only found in very restricted areas because $t_{1} \mathrm{e}$ surface is covered by a thick mantle of eluvial and deluvial sediments or by a loess or loess-like sediment layer 2 to 20 metres thick, and less often by sand. These superficial deposits serve as the parent material for the present soil cover.

The genetic soil types of the hilly areas are: brown forest soil with admixtures of clay (Parabraunerde) in the cooler and wetter areas, brown forest soil (Braunerde) on loess-like sediments, rusty-brown forest soil on sand, and varieties of grassland soils on the lower, drier and warmer ridges. On the floors of depressions and on the larger valley bottoms, a wide range of hydromorphic soil varieties are formed, depending on water circulation and the position of the groundwater table; for example, meadow and marshy soils, meadow chernozems and peat.

The dissected surfaces of higher relief energy and the cooler south facing slopes are still covered by natural oak and beech forest because cultivation is difficult and would result in vigorous soil erosion. On the other hand, the surfaces of low relief energy are mainly cultivated, with intermingled wood, meadow and pasture land.

The macroclimate controls the development of the hydrogeographical network and the vegetation and genetic soil types. As a generalization, it can be stated that the western and northern parts of the country are cooler and have higher precipitation than the central, eastern and southern regions. Furthermore, the hilly regions in the north-east are more continental in character than those in the west. Within these general outlines a mosaic of local climatic varieties can be observed on the many different landscape features, which depend on surface conditions and which are effected by the macroclimate.

The authors' research has shown that the following characteristic microclimatic groups can be identified along some of the asymmetrical valleys parallel to the Central Mountains:

Type group 1. occurs on north facing slopes with a cool microclimate, and the margins of valley bottoms.

a. The most frequent type is covered with mesophilic forests usually developed on forest soils derived from stratified sandy and clayey slope sediments. 
Shrub level is relatively poor. Uniformity of temperature, evaporation and wind is characteristic owing to decreased irradiation and eradiation. The comparatively low evaporation values observed on bright summer days are interpreted as being the result of feeble irradiation, low air temperature and shelter from winds. The characteristics of this microclimatic type make it desirable to preserve the existing closed forest cover by selective cutting, thus producing high quality timber. The planting of foreign tree types (e.g. pine) may result in the deterioration of the stand. The continuous shrub cover and the closed sward together with the well-developed dead leaf layer prevents practically any erosion of the fertile soil layer.

b. Cultivated slopes exposed to the north are restricted to much smaller areas. They are characterized by much more extreme daily microclimatic changes, and by strong winds, violent raindrop action, increased soil destruction and erosion danger. The possibility of agricultural utilization is an inverse linear function of slope inclination. Afforestation in harmony with the natural conditions can be achieved most conveniently, by planting forest species corresponding to the natural environment.

Type group 2. occurs on gentle south facing slopes.

a. The most frequent type is covered by zonal brown forest soils derived from slope sediments or as a result of local conditions, by extrazonal grassland soil. It is characterized by extremes of temperature, strong irradiation, eradiation and winds, and intensive evaporation, all of which produce warm dry conditions.

Gentle slopes are the proper place for arable cultivation and intensive vitiand orchard-culture. On steeper slopes soil desiccation, deflation and erosion danger are imminent and appropriate soil protection measures must be undertaken. On slopes steeper than $20^{\circ}$ the possibilities for agricultural utilization gradually diminish. As a consequence of forest cutting xerothermic steppe meadows arise on which pasturing provokes the proliferation of weeds. It is desirable to stop pasturing in such areas, because trampling by animals results in serious destruction of the soil and other damage. A satisfactory solution appears to be the gradual replanting of the zonal thermophilic xerothermic forest which corresponds to the natural environmental conditions or the establishment of viticulture and orchards on artificial terraces provided with adequate soil protection.

b. On slopes of southerly exposition, with soils and rock types similar to those described in section (a), xerothermic oak woods flourish, possessing a luxuriant shrub cover. Although the strong irradiation and air movements characteristic of gentle south-facing slopes are moderated by vegetation, the resulting local climate is drier and warmer than on slopes exposed to the north. As said before, intensive arable cultivation can be substituted for forest on gentle slopes, although on steeper slopes the forest cover must be preserved.

Type group 3. occurs on subhorizontal or gently sloping ridges and crests situated between valleys. - The natural vegetation covering the forest soils depends on the macroclimate and consists of xero- and mesophilic forest. They thrive vigorously and produce large quantities of timber. With deforestation, these areas can be utilized for agricultural purposes in many ways, depending on the lithological, hydrogeographical (ground-water!), micro- 
climatological and soil conditions. The microclimatic properties of cultivated agricultural areas are determined by the climate associated with the cultivated plants and, as in the case of type group 3. on plain surfaces. In the bends of small lateral valleys, the possibility of agricultural utilization diminishes with increasing slope angle, chiefly in consequence of the greater danger of soil destruction. The microclimatic characteristics are modified by different slope exposure, but they retain their close association with the vegetation stands.

Type group 4. is found on slopes in hills areas exposed to the east and west. They are intermediate in character between the microclimates of northerly and southerly exposure, respectively. Eastern and southern slopes are closely related, and similarly for western and northern slopes. This relationship is a function of the macroclimate, since from West to East the cooler, wetter, and moderate atlantic influence yields to a drier, warmer, and more extreme, continental character which is displayed during the period of plant growth.

Type group 5. is a wet and cool microclimate occurring on valley bottoms and in small basins. The natural vegetation on mainly hydromorphic soils formed on fluvial or slope sediments depends on the level and the current conditions of the ground-water.

a. One type is represented by various grove and marsh forests. Their common feature is that they produce cool and wet air conditions. Temperature variations are small, because the cooler air masses flowing down from the higher slopes during the night become tempered on the forest-covered surfaces. Inside the forest moisture content is high during daytime too, and the heat in the subsoil water is absorbed by the air during the night hours. It is preferable to preserve the natural forest and to lower the water table, although where the water table is at sufficient depth below the surface now, the cultivation of kitchen-garden vegetables is recommended. For this purpose valley bottoms of low relief energy and with not too sticky soils are very suitable, but the cultivation of plants sensitive to frost and cold and having a long growth period is to be avoided. (The phenological demands of the plants to be cultivated must be taken into consideration.)

b. After a century of lumbering marshy meadow, hayfield and tall sedge associations have become very common on surfaces belonging to this type group. Lacking the moderating effect of forest they are characterized by increased nightly radiation and by the accumulation of cold air descending down the slopes. For this reason temperature minima dangerous for plant cultivation occur very often even during the summer months, and in August temperatures of 1 to $3{ }^{\circ} \mathrm{C}$ were measured on days when the macroclimatic mean was $22{ }^{\circ} \mathrm{C}$. The valley bottoms deprived of forest cover are places of mist and dew precipitation. They can be utilized for the cultivation of kitchen garden and other vegetables of short growth period, partly for natural hayfields and where the groundwater table is close to the surface for the establishment of fish ponds. 


\section{INVESTIGATIONS IN MOUNTAINS OF MEDIUM HEIGHT}

The Hungarian Central Mountains extend from the western end of Lake Balaton in the centre of Transdanubia to the Tokaj Mountains in the northeast.

The Mecsek Mountains are an isolated unit occurring in South Transdanubia, just to the north of the town Pécs.

These mountains, on average, are between 400 and $800 \mathrm{~m}$ a.s.l., the highest point being Mount Kékestető in the Mátra Mountains, which is $1,015 \mathrm{~m}$. above sea level. Relief energy ranges from 200 to 600 (max. 800) m per square $\mathrm{km}$. The Central Mountain range is made up of a succession of strongly denudated block mountains consisting of Mesozoic and Tertiary sediementary rocks (chiefly limestones and dolomites), and neogene andesite, and rhyolite volcanics. They are tectonically very dismembered.

The karstic areas are characterized by a three-dimensional fluvial network, although there is little surface water, and by extensive cave systems. Abundant karst springs appear at lower levels along the junction of the calcareous and impermeable argillaceous-sandy sediments, which flow towards the local base level of erosion. In the volcanic areas surface water is more abundant and valley dissection is extensive.

Slope conditions are variable. Topographical and hydrogeographical factors determine, to great extent, the nature of the vegetation, local climate and soil types. Natural vegetation is zoned according to altitude, and changes from closed canopy oak forest, at low levels through beech forest, with bare karstic surfaces, to steppe meadows and rock grasses at the highest altitudes.

The genetic soil types present include various forest soils and locally rendzina and "eru-basic" soils. The nature of the parent material plays an important role in the formation of the lithomorphic soils, as does water in the hydromorphic soils of the valley bottoms. On the slopes large areas have been completely eroded producing rocky and skeletal soils.

The climate is characterized by a decrease in temperature and an increase in precipitation with altitude. The spring and autumn precipitation maxima in the Central Transdanubian Mountains reflect a submediterranean influence, while in the northeast the midsummer maxima prove the subcontinental character of the climate.

Compared with the plains and hilly regions, the microclimates in the mountains show even more variety and extremes, and warrant special attention in the context of landscape evaluation. The character of the microclimates is primarily determined at mesoclimatic level by height relative to sea level and by such topographic factors as exposure and slope angle.

Five type groups can be distinguished.

Type group 1. which is not characteristic, oceurs in non-exposed, "plakor" positions or in broad valley bottoms where vegetation can develop undisturbed to a zonal association. It is directly influenced by macroclimata. Other environmental factors effecting these microclimates are soil, parent material, and groundwater, etc.

Type group 2. comprise cool microclimates without direct insolation, which occupy, first of all, places of northern, northwestern and northeastern expo- 
sure and deep and narrow valley bottoms. Rock and soil type play a less important part. Its vegetation is usually extrazonal being normally associated with higher altitudes or more northerly areas.

Type group 3. consists of warm, dry microclimates resulting from intensive insolation. Being exposed to the south, southeast or southwest, its vegetation belongs to an essentially "warmer" zone.
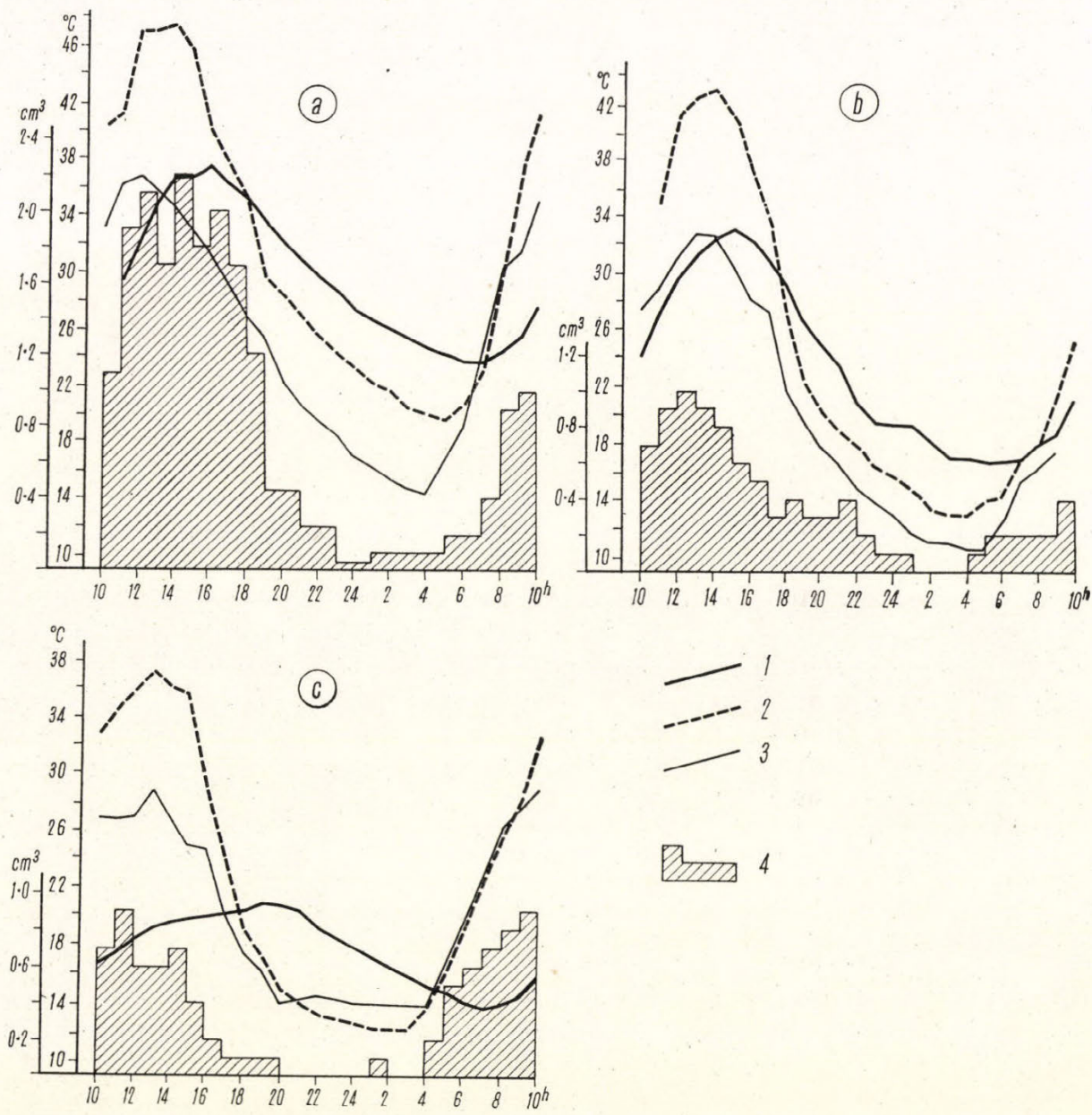

Fig. 1. Temperature and evaporation curves for three rock grasses of similar physiognomy situated in different vegetation zones. $a=$ mediterranean (Cymbopogono-Brachypodion ramosi, Albania, 10-11 July 1960, Station 3, P. Jakucs 1967). $b=$ submediterranean (Seseleo leucospermi-Festucetum pallentis, Hungarian Central Mountains, 16-17 May 1957, Station 2, P. Jakucs 1959). $c=$ subcontinental (Caricetum humilis stipetosum pulcherrimae, North Hungarian Central Mountains, 7-8 July 1953. Station 3-4, P. Jakucs 1954).

1 = temperature curve in the soil at $5 \mathrm{~cm}$ depth. $2=$ temperature curve at the surface. 3 = temperature curve at a height of $20 \mathrm{~cm} .4=$ amount of water evaporated (in cubic $\mathrm{cms}$ ) at a height of $20 \mathrm{~cm}$ 
Type group 4. has a unique vegetation, resulting from exposure to extreme wind action.

Type group 5. comprises wet and relatively windless, microclimate, with characteristic vegetation.

Within type groups, individual types are determined by the following factors: nature, depth, colour and texture of the parent rock, colour and structure of the soil, and type and nature of vegetation cover, for example closed canopy, dominant species and composition. Special factors to be mentioned are: detritus (rock streams and stone rivers), cliff, edge, doline, sinkhole, water bank, forest fringe, etc.

The great variety and combinations of substrate in the Hungarian Central Mountains produces so many microclimatic types, that it is difficult to enumerate them. Instead, a concrete example is presented in order to demonstrate that similar or identical microclimatic data (obtained from instrumented overservations) for homogeneous areas in identical atmospheric positions, signify similar or identical landscape elements. These regularities are more or less valid, as it will be shown, over even greater geographical distances (Jakucs 1967).

Figure 1 shows the daily variations in the most important microclimatic factors in the North Hungarian Central Mountains, the Transdanubian Central Mountains and the Albanian Central Mountains in the west of the Balkan Peninsula. The measurements were made on a randomly choosen day, which, in all three cases coincided with warm summer day, anticyclonic conditions, bright weather and local winds. Diagrams A, B, and C in the figure demonstrate mediterranean (Albania), submediterranean (Transdanubian Central Mountains) and subcontinental (North Hungarian Central Mountains) microclimatic types. Their similarity is striking, but the slight differences deserve to be mentioned. In the case of the mediterranean type evaporation is continuous, while in the other two there is a significant pause in the night during which dew precipitation occurs. In the mediterranean type soil temperatures are high, cooling is smoother and slower, and maxima and minima are relatively higher. In contrast, the subcontinental type is of more extreme character, and the curves reflect rapid cooling and warming, while the nightly minima are lower. The submediterranean type is transitional between these two.

All these differences derive from the three areas being rather distant from each other. These apart, the three graphs agree in all essential points. In fact, the similar microclimatic conditions may be attributed to their occurring on identical landscape types. Investigations on the spot have indicated that in all three cases exposure, parent rock, soil structure, slope, height and vegetation cover were the same.

From the point of view of landscape evaluation the character of these three microclimatic areas calls attention to the fact that landscape elements of this type produce conditions that are not favourable for forest growth. At present each of the three places is covered by original grass vegetation. An artificial and very expensive afforestation of the karstic surfaces in question would hardly be a success. 
Finally, a few sectors of the economy will be mentioned, in which the results of landscape and microclimatic research in Hungary can be utilized. These are as follows:

1. In the course of the afforestation of bare, karstic and denudated surfaces, in choosing the most appropriate tree and shrub species, and the most purposful methods of plantation.

2. In forest areas in making the correct choice of forest cultivation and renovation techniques and in selecting the best tree species in order to increase timber production.

3. In meadow cultivation and pasture land, the most favourable grass composition is indicated.

4. In deciding on the most productive way to utilize water covered areas such as hayfields, reed marsh, rice culture, and fish ponds.

5 . In pointing out other kinds of agricultural land utilization (vineyard, orchard, ceral and hoe plant cultures and vegetable gardens).

6. In industrial and economic-geography landscape and terrain correction (town development projects, location of houses, routes, industrial establishments, and bathing and holiday resorts).

7. In the designation of areas to be preserved as national parks.

\section{BIBLIOGRAPHY}

Andó, M. (1959): Die Einwirkung der Donau und der Oberflächenformen auf die mikroklimatis chen Verhältnisse des Uferrandes bei Alsógöd. Acta Climatologica (Szeged) 1, pp 45-53.

Andó, M. (1966): Homoktérszín mikroklimatikus hőmérséklet-változása különböző időjárási viszonyok alkalmával (Microclimatic temperature variations of a sand surface under different weather conditions). Földr. Ert. 10, pp 1-22.

Aszód, L. (1936): Adatok a nyírségi homoki vegetáció ökológiájához és szociológiájához (Contributions to the ecology and sociology of sand vegetation in the Nyírség). Tisia 1, pp 75-105.

Bacsó, N. and Zólyomi, B. (1934): Mikroklíma és növényzet a Bükk-fennsíkon (Microclimate and vegetation on the Bükk Plateau). Az Időjárás pp 177-196.

Bárány, I. (1967): Der Einfluß des Niveauunterschiedes und der Exposition auf die Lufttemperatur in einer Doline im Bükk-Gebirge. Acta Climatologica (Szeged) 7, pp 85-109.

Boer, W. (1959): Zum Begriff des Lokalklimas. Zeitschr.f. Met. 13, pp 5-11.

Boros, J. (1963): Angaben zum Mikroklima des Gebietes "Forrás" von Pótharaszt. Acta Climatologica (Szeged), 3-4, pp 33-47.

Boros, J. (1966): Temperaturverhältnisse auf Bergwiese und in Tannenwaldbestand an sonnigen Sommertagen. Acta Climatologica (Szeged) 6, pp 53-72.

Defant, F. (1961): Local winds. Compend. of Mt. (Am. Met. Soc.) Boston, pp 655-672.

Endrödi, G. (1963): A Tihanyi-félsziget terepklimatológiai jellemzése (Terrain climatological characterization of the Tihany Peninsula). Időjárás 67, pp 244-249.

Endrődi, G. and Götz, G. (1964): A víz- és léghőmérséklet kölcsönhatása sugárzásos napokon a Balaton térségében (The interrelations between water and air temperature on days of radiation in the Lake Balaton region). Időjárás 68, pp 371-376.

Gregor, A. (1955): Ein Behelf zur Klassifikation des Expositionsklimas. Wetter und Leben 7, pp $275-276$.

Gregory, P. H. (1960): Aerobiologie des Freien Luftraums. Endeasour 19, pp 223-228.

Hargitai, Z. (1941): Mikroklíma vizsgálatok a nagykőrösi Nagyerdőben (Microclimatic investigations in the Nagyerdő forest at Nagykőrös). Nagykörös növényvilága III. (Plant life of Nagykőrös III). Acta Geobotanica Hungarica 4, pp 197-240.

Hargitai, Z. (1943): Mikroklímavizsgálatok a Sátor-hegységben Sárospatak környékén (Microclimatic investigations in the Sátor Mountains around Sárospatak). Acta Geobotanica Hungarica 5 , pp $290-314$. 
Horánszky, A. (1957): Mikroklima-Messungen am Szentmihály-Berg bei Nagymaros. Ann. Univ. Sc. Bp. de Rol. Eötøös nom. Sect. Biol. 1, pp 89-131.

Horváth, I. and Fehér, V. I. (1965): The lesser maximum of evening temperature. Acta Climatologica (Szeged) 4-5, pp 83-91.

Horváth, I., Précsényi, I. and Fehér, V. I. (1963): Verwendung mathematisch-statistischer Methoden in der Abgrenzung von Mikroklimaräumen. Acta Climat. (Szeged), 2-3, pp 3-12.

Jakucs, P. (1954): Mikroklímamérések a Tornai Karszton tekintettel a fatömegprodukcióra és a karsztfásításra (Microclimatic measurements on the karst areas of the Torna karst region with regard to mass timber production and karst afforestation). Annal. Hist. Nat. Mus. Nat. Hung. 5. pp 149-173.

Jakucs, P. (1959): Mikroklimaverhältnisse der Flaumeichen-Buschwälder in Ungarn. Acta Agronom. Hung. 9, pp 209-236.

Jakucs, P. (1965): Complex vegetation mapping in the Hungarian Medium Mountains and its connections with practical forestry. Acta Agronom. Hung. 13, pp 303-327.

Jakucs, P. (1967): Mikroklimatische Untersuchungen im Berührungsgebiet der mediterranen und submediterranen Vegetation Albaniens. Arch. Naturschutz und Landschaftsforsch., 7, pp 3-30.

Jakucs, P., Marosi, S. and Szilárd, J. (1963): Mikroklímamérések a Jaba-völgyben (KülsőSomogy) (Microclimate measurements in the Jaba Valley in Outer-Somogy). Földr. Errt. 12, pp 357-378.

Jakucs, P., Marosi, S. and Szilárd, J. (1964): Mikroklímamérések és természeti földrajzi megfigyelések az Osztopáni meridionális völgyben (Microclimatic measurements and physicogeographical observations in the meridional valley at Ostapan). Földr. Ért. 13, pp 425-446.

Jakucs, P., Marosi, S. and Szilárd, J. (1967): Mikroklimamérések és komplex természeti földrajzi típusvizsgálatok a belsö-somogyi futóhomokon (Nagybajom) Microclimatic measurements and complex physical-geographical survey of types on the blown-sand in Interior Somogy (at Nagybajom). Földr. Ért. 16, pp 161-185.

Kiss, Á. (1955): Temperaturextreme auf dem Sande von Ưllés. Acta Geographica (Szeged) 1.

Kiss, Á. (1959): Angaben zur Erwärmtheit einer Sanddüne. Acta Climat. (Szeged) 1, pp 55-72.

Knoch, K. (1963): Die Landesklimaaufnahme (Wesen und Methodik). Ber. d. Deutsch. Wetterdienstes. No. 85.

Kovács, M. (1966): Die Wirkung der geomorphologischen, mikroklimatischen und Bodenfaktoren auf die Entwicklung des Standortes der azidophilen Wälder im Mátra-Gebirge. Acta Botanica Hungarica 12, pp 293-324.

Kozma, F. (1964): A talajközeli légrétegek éjszakai energiaháztartása (Night energy balance of the near-soil air layers). Időjárás 68 , pp 33-41.

Kozma, F. and Stollár, Á. (1963): A felhôzet hatása a talajközeli légrétegek lehülésére (The effect of clouds on the cooling of air layers near the soil). Időjárás 67, pp 297-299.

Kozma, F. and Szilágyi, F. (1963): A talajhőáramlás hatása a talajközeli légrétegek lehúlésére (The effect of soil heat flux on the cooling of near-soil air layers). Időjárás 67, pp 43-46.

Magyar, P. (1935): Párolgásmérések az Alföldön ligetes homoki erdőkben (Evaporation measurements in the sand grove forests of the Alföld). Erdészeti Kisérletek 37, pp 76-120.

Marosi, S. and Szilárd, J. (1964): Landscape evaluation as an applied discipline of Geography. Studies in Geography 2, pp 20-35.

Marosi, S. and Szilárd, J. (1967): Új irányzatok a MTA Földrajztudományi Kutató Intézet természeti földrajzi kutatásaiban (New ways in the physico-geographical researches of the Geographical Research Institute of the Hungarian Academy of Sciences). Földr. Közl. $1, \mathrm{pp}, 1-24$.

Papp, L. (1957): Szemelvények az erdészeti mikroklímakutatás köréből, különös tekintettel a kopár oldalakra (Selected passages from microclimatic forestry research with special regard to bare slopes). Időjárás 61 , pp 98-110.

Péczely, Gy. (1958): A Balaton hatása a nedvesség és a hömérséklet alakulására (The effect of Lake Balaton on moisture and temperature variations). Időjárás 62, p. 207.

Péczely, Gy. (1962): A Balaton helyi szélrendszere (The local wind system of Lake Balaton). Idöjárás 66, pp 83-89.

Pécsi, M. (1964): Ten Years of Physiogeographic Research in Hungary. Studies in Geography 1. Budapest: Akadémiai Kiadó.

Scaätta, H. (1936): Terminologie climatique, bioclimatique et microclimatique. La Météorologie 11, pp 342-347.

Schmidt, W. (1934): Das Bioklima als Kleinklima und Mikroklima. Biokl. Beibl. 1. 
Soó, R. (1929): Experimental-ökologische Studien am Balaton. M.T.A. Math. és Term. Tud. Ert. 46, pp 602-614.

Sutton, O. G. (1953): Micrometeorology. New York: McGraw Hill Book Co.

Thornthwaite, C. W. (1953): Topoclimatology. The John Hopkins Univ. Lab. of Climat.

Wagner, R. (1955): Különböző ökológiai viszonyú területek mikroklímamérési eredményei (Results of microclimate measurements on areas with different ecological conditions). Idôjárás 59, pp 165-169.

Wagner, R. (1955): A mikroklimák földrajzi elrendezödése Hosszúbércen (The geographical distribution of microclimates on the Hosszúbérc). Orsz. Met. Int. Kiadv. No. 20.

Wagner, R. (1956): Mikroklímatérségek és térképezésük (Mapping microclimates). Földr. Közl. 4 (80), pp 201-216.

Wagner, R. (1963): Der Tagesgang der Lufttemperatur einer Doline im Bükk-Gebirge. Acta Climat. (Szeged) 2-3, pp 49-79.

Wagner, R. (1965): Die Temperatur des Bodens, des Wassers und der Luft in Kopáncs. 1. Acta Climat. (Szeged) 4-5, pp 3-81.

Wagner R. (1966): Die Temperatur des Bodens, des Wassers und der Luft in Kopánes. 2. Acta Climat. "(Szeged) 6, pp 1-51. 



\section{APPLIED SOIL GEOGRAPHY AND AGRICULTURE}

by

L. GÓ C Z Á N

\section{THE PROBLEM OF APPLIED SOIL GEOGRAPHY}

At present no definition of applied soil geography is contained in the literature. Therefore its content has not been defined either.

The character of the present study does not allow one to go into detail concerning the scientific definition of applied soil geography. It is necessary, however, to clearly expose the problem as far as our present level of knowledge will allow. First of all, some preliminary questions have to be answered.

What is the difference between fundamental and applied research in soil geography? How are these two delimited from each other? Does the latter possess an independent domain of investigation making it a separate branch of science, or is it merely part of soil geography? What are its relations to pedology?

These questions must be formulated more concretely and they can then be answered, at least approximately, by means of examples chosen from the author's investigations which were carried out in the Marcal Basin of the Little Hungarian Plain.

A $1: 100,000$ scale map of the genetic soil types of the Marcal Basin has been prepared. This map shows a regular distribution of the soil types, reflecting, in its general outlines, the development of their respective properties. But it is not sufficiently detailed for suggesting correct farm management. It may prove useful, however, for planning at the county level. The requirements and purposes of a given farm need a more detailed genetic soil map, on a scale of at least $1: 10,000$. Even the applicability of a $1: 25,000$ scale genetic soil map is restricted to the demonstration of certain spatial relationships, although these can be shown in more detail than at a scale of $1: 100,000$. A soil map on a scale $1: 10,000$ (or more detailed) fulfils the demands of farm management. Consequently, such a map is, notwithstanding its genetic character, an applied soil map, and a characterization of soil types made with similar thoroughness would belong to "applied soil geography".

In the given case, the difference between the description and maps of "fundamental research" type and those of "applied" character is a mere question of scale.

A more thorough examination of the same example reveals that a detailed (1:10,000 scale) genetic soil map of the hilly areas of the basin would be a soil destruction map, since soil varieties would be discerned on it, which are determined according to the degree of soil erosion. In other words, one is dealing with a map demonstrating the state or grade of soil destruction. Such a map at any scale is an "applied" map of special aim. Soil destruction is dealt with by the Commission on Soil Technology within the organization of the 
International Society of Soil Science and exhibits by its very name its "applied" character.

All these considerations seem to suggest that there is but a difference of scale between "fundamental research" and "applied" soil geography, since their content and method are essentially the same. In consequence, no sharp line can be drawn between these two, and hence, lacking as it does any independent field of investigation, applied soill geography is based on merely subjective speculations and its right to exist is debatable.

However, another example will be presented that indicates the contrary. In the course of the author's investigations, a natural soil ameliorating substance was found. It was subsequently explored, delimited, and its tonnage was calculated. On the basis of the prescribed laboratory tests it turned out to be of excellent quality. Its exploitation has been proposed to the National Enterprise for Soil Amelioration (Góczán 1966).

Now, this work could by no means be classified as fundamental research in soil geography. Nevertheless, field and laboratory investigations have led to the conclusion that the material in question is a product of the weathering of slopes consisting of Leitha limestone during the glacial period. This being known, one had only to trace the distribution of its parent rock in the investigated region in order to ascertain its presence on the slopes. It could be mapped by a minimum number of bore holes.

For the mapping of this ameliorating substance in the field, geographicalabove all geomorphological-knowledge was required. Without such, exploitation would have been scarcely possible. Even in the best case it would have needed an expensive and prolonged exploration to detect a reserve worth exploiting. Knowledge of soil science was necessary for pointing out the fertilizing nature of this material and to confirm it on the basis of laboratory analyses.

For the study of the regularities of soil geography in the Marcal Basin by means of the investigation of the soil-forming factors and the genetic soil types the exploration of the mineral fertilizer was not needed. The latter work was performed explicitly to enable the fertility of the acidic soils of this landscape and of the neighbouring ones to be improved.

Since the exploration of similar ameliorating materials is to be undertaken most advantageously by specialists in soil geography, this task belongs expressly to the domain of applied soil geography. Moreover, it constitutes a specific task, and proves the right of this discipline to independent existence.

There are a great number of research tasks that require a knowledge of soil geography but do not require the study of soil-forming factors and genetic soil types.

Such a task, among others, is the investigation of soil destruction in sloping areas, which requires the construction of a soil erosion map. Other details to be cleared are the rate and intensity of soil destruction, the thickness of the fertile stratum, the quality of the humus and the nature of the clay minerals in the soil, the water balance of the soil (soaking, water capacity, permeability), and the amount of run-off. Since the intensity of insolationwhich effects the inclination of slope surfaces already dried by surface loss of water to drought-differs according to slope aspects, the heat and air 
exchange of the soil cover are to be examined as well. The combined waterheat- and air-balances of the soil constitute the soil climate. Their successful study assumes a thorough knowledge of the genetic soil type, including laboratory tests.

As it has been said above, the investigation of soil climate on slopes in Hungary also requires specialization in soil geography. A high percentage of Hungary's mountain and hill slopes are covered by forest soils. It is commonplace that slopes of southerly aspect have a drier type of soil climate than the plain-surface soil cover of Hungary's chernozem areas. The study of the relationship between soil climates and various landscape types requires a geographical view from the pedologist engaged in soil conservation work. It is the soil geographer who has the best prospects of success in this field.

Such research must be performed to promote planned soil conservation, and to enable reasonable cultivation of hilly districts. They are obviously applied scientific investigations and are not only founded upon fundamental research in soil geography (genetic soil types), but also upon the results of applied geomorphology (the mapping of slope categories), and agrotechnics (state of soil cultivation, vegetation cover and methods of cultivation).

It would be a mistake, however, to affirm that soil conservation is the task of applied soil geography. Soil conservation in sloping areas is an interdisciplinary product from experts in several branches of science. Its preparation involves the co-operation of soil geographers, geomorphologists, economic geographers or agricultural economists, agronomists, foresters, meteorologists and surveyers.

Soil conservation itself, i.e. cultivation of the slopes, is beyond doubt an agricultural and engineering task.

In summary, applied soil geography on the one hand, investigates the erosion and soil climatological aspects of soil conservation, and on the other hand, it explores and surveys natural fertilizers to be used in soil reclaimation.

Beside these, detailed genetic mapping (scale at least $1: 10,000$ ) is regarded as applied soil geography as well.

What has been said above does not justify an abstract definition of applied soil geography. This would be quite beside the purpose of the author. Only the problem was posed, because in the author's opinion the development of soil geography has reached a stage of differentiation which stimulates further progress. Moreover, modern age urges all possible applications of scientific achievements and one may find optimal conditions of evolution if they are fitted into an appropriate formal pattern.

In the following, the author is setting out his own opinion about the content and research methods of physical (mainly soil) geography in the service of soil conservation and cultivation to protect the soil, because at present a certain state of disorganization and uncertainty characterizes research work in this field. 


\section{TASKS OF APPLIED GEOGRAPHY IN THE FIELD OF SOIL CONSERVATION}

An extensive literature exists on soil destruction and soil conservation both in Hungary and abroad.

In the author's opinion the following authors are the most important from the point of view of the present paper.

Soviet authors: Sobolyev, S. S., Bityukov, K. K., Sus, N. I., Kostyakov, A. N., Presnyakova, G. A., Shvebs, G., Kaplan, S. M., Yakubov, T. F., Lopatin, G. V. and Silvestrov, S.

American authors: Ayres, O. C., Bennett, H. H., Norton, E., Woodbura, R., Zingg, A. W., Chepil, W. S., Mazurak, E.P., Woodruff, N. P., Siddoway, F. N., Fryhear, D. W., Ambrust, D. V., Wheeler, G., Gottschalk, L., Wischmeier, W., Smith, D.

German authors: Schultze, J., Stremme, H.

Czechoslovak authors: Mazan, B., Juva, K., Cablik, J.

Rumanian authors: Motoc, M.; Trasculescu, Fl.

Israeli authors: Seginer, I., Morin, J., Shachori, A.

Italian author: Sodini, E.

Turkish author: Yamanlar, $\mathrm{O}$.

All these authors have been taken into consideration.

The following Hungarian literature was found to be closely related to our topic: Mrs Bodolay, I. (1965a, 1965b, 1966a, 1966b), Duck, T. (1960a, 1960b, 1960c, 1962, 1964), Erődi, B. (1965), Erődi, B. and Horváth, V. (1960), Erődi, B. and Horváth, V. (1965), Erődi, B., Horváth, V., Kamarás, M., Kiss, A. and Szekrényi, B. (1965), Egerszegi, S., Fekete, Z., Göncz, Á. and Mattyasovszky, J. (1954), Fekete, Z. (1952, 1953, 1954, 1958, 1964), Fekete, Z., Hargitai, L. and Zsoldos, S. (1964), Góczán, L. (1966), Horváth, V. and Erődi, B. (1963), Kazó, B. (1960, 1966a, 1966b), Kiss, A. (1962), Lovász, Gv. (1965), Mattyasovszky, J. (1953a, 1953b, 1956, 1957a, 1957b), Pécsi, M. (1962, 1965), Sipos, G. and Lammel, K. (1964), Stefanovits, P. (1959, 1962, 1963a, 1963b, 1964, 1966), Stefanovits, P. and Szücs, L. (1961), Szücs, L. (1966).

An appraisal of the enumerated literature not only gives us a knowledge of soil conservation, but also makes us aware of the fact that specialists from many disciplines have been active in this field, owing to the complexity of soil conservation. It may be stated that the most significant progress is displayed always by that particular branch of soil conservation which corresponds most closely to the scientific specialization of the experts engaged in the operative management of and projects concerned with soil conservation. Since soil erosion causes serious damage even to the national economy, the urgency of soil conservation dictates a very high speed of execution. For this reason an adequate scientific foundation for this work of utmost significance is almost impossible to achieve.

The adaptation of international scientific progress furnished a scientific basis that was sufficiently precise for planning on a general scale. Proceeding, however, towards the preparation of more detailed "directive and executive projects", the peculiarities of the country begin to prevail. Unfortunately, the expert staff in Hungary is too small in number for taking account of all these, 
owing to the extent of the territory in question and the speed required. This applies even to general planning, not to speak of the qualified scientific staff needed to establish the scientific foundations of detailed soil conservation projects in Hungary.

At present this is the principal obstacle to successful soil conservation in Hungary's hilly regions. Hence it is very important to try to overcome this through the most economical management of the given expert staff. One method consists of entrusting the creation of a proper scientific and technical basis for each particular task of soil conservation to the specialists most versed in that particular problem. In this way considerable time could be spared for appropriate ulterior scientific specialization, making it possible for research geographers to offer very essential aid to soil conservation.

In the field of soil protection, a complex approach involving the methods of both physical and economic geography would be most desirable. Soil conservation in hilly and mountainous regions, the second step in protection work, lies in the field of economic-geography but is strictly built upon the rigorously valid conditions determined by the physical environment. Thus an individual geographer is wholly incapable of performing all the tasks of soil conservation in a given area at the required scientific level. As a consequence of current geographical training, the physical and economic aspects of soil conservation are separately treated. This is the reason why the present paper is confined to soil conservation problems of a physical geography nature only, and, more specifically, owing to the author's aim, to those aspects of conservation that concern soil geography.

During the preparation of the National Long-Term Programme of Water Supply Management, a Long-Term Soil Conservation Project was elaborated by the staff of the Designing Office for Water Resources at a scale of 1:100,000. Since this project was completed without the inclusion of detailed field investigations, those tasks of a physical geography character will be enumerated which are going to promote detailed soil conservation.

\subsection{SPECIAL GEOMORPHOLOGICAL MAPS FOR SOIL CONSERVATION}

Since a scientifically well-founded and detailed programme of soil protection (directive and executive projects) is to be aimed, two kinds of maps are to be prepared by the geomorphologists. These are a map of the soil-bearing or soil-forming rocks on sloping surfaces and secondly a map of slope categories. The latter may be plotted in different ways, but the generally accepted principles were laid down by Erödi-Horváth and Lovász in 1965.

2.11. The map of soil-bearing rocks on sloping surfaces

Geological maps of Hungary on a scale of $1: 25,000$ are at our disposal. Why is it then necessary to have such maps prepared by geomorphologists? 
Soil conservation aims to reduce soil destruction to an acceptable level and to minimize precipitation loss by promoting its infiltration into the soil, in order to maintain adequate soil moisture for root nourishment.

For the realization of this, a knowledge of the parent rock is indispensable. Its water balance will differ from that of the soil. It may facilitate, or partially or even completely prohibit infiltration. This is of special importance in the case of non-concave slopes, where the humus is generally very thin, and especially at the point of slope inflexion, where the soil-bearing rock outcrops as a skeletal soil. The importance of this feature is to be stressed in the context of soil destruction, because in consequence of its differential porosity erosion may be eventually accelerated or slowed down, respectively. The extreme cases are the following.

1. A loose layer consisting of pebbles soaks up and filters the water penetrating it from the surface. In comparison with Zone $B$ of the original forest soil, over which the water passed without infiltration, the amount of runoff decreases abruptly on the grave, as does erosion.

2. When the skeletal soil at the point of inflexion strip is formed of clay rich in montmorillonite, the opposite effect is produced to that which occurs on gravel.

The character of the soil bearing rock is also felt under a thin soil cover as well, although it is less significant. It may accelerate or slow down the vertical movement of water passing through the soil, resulting in more intensive erosion, pernicious pseudogleyification, solifluction and eventually slumping.

It is thus apparent that a knowledge of the soil bearing rock is very desirable from the point of view of soil conservation. Field and laboratory investigations must be undertaken including clay analysis, soil physics and water balance examinations (see below, points 2.21 and 2.22).

A new survey is therefore indispensable in spite of the existence of geological maps, which show rock outcrops in a manner that is insufficient for water supply management. This deficiency increases on slopes, because Hungarian geological maps at a scale of $1: 25,000$ do not show the different slope sediments.

In our hilly areas finely stratified slope sediments are extensive (Pécsi, M. 1962). The very thin strata (of a millimetre or so) each have a different water balance. Such a succession of thin strata requires a very different approach from a bed composed by sediments of similar granulometric composition, but of greater vertical extent. (For example, stratified slope loess and aeolian loess of vertical capillary structure.)

Such precise characteristics of deluvial slope sediments are appreciated by geographers only. Moreover no detailed geological mapping is going on in regions of loess sediment. Therefore it is up to research geographers to prepare the maps in question. Mapping at a $1: 25,000$ scale may be considered only a provisional solution, because other maps, especially those showing slope categories, may only attain the necessary precision at a scale of $1: 10,000$. Consequently, all other maps must be adapted to this requirement.

Since soil conservation may be successful only if applied to the whole of a catchment area, map preparation should be fitted to and coordinated with these. 
Rock types must be illustrated in accordance with a genetically defined nomenclature and in the case of loose sediments granulometric composition must be taken into consideration as well.

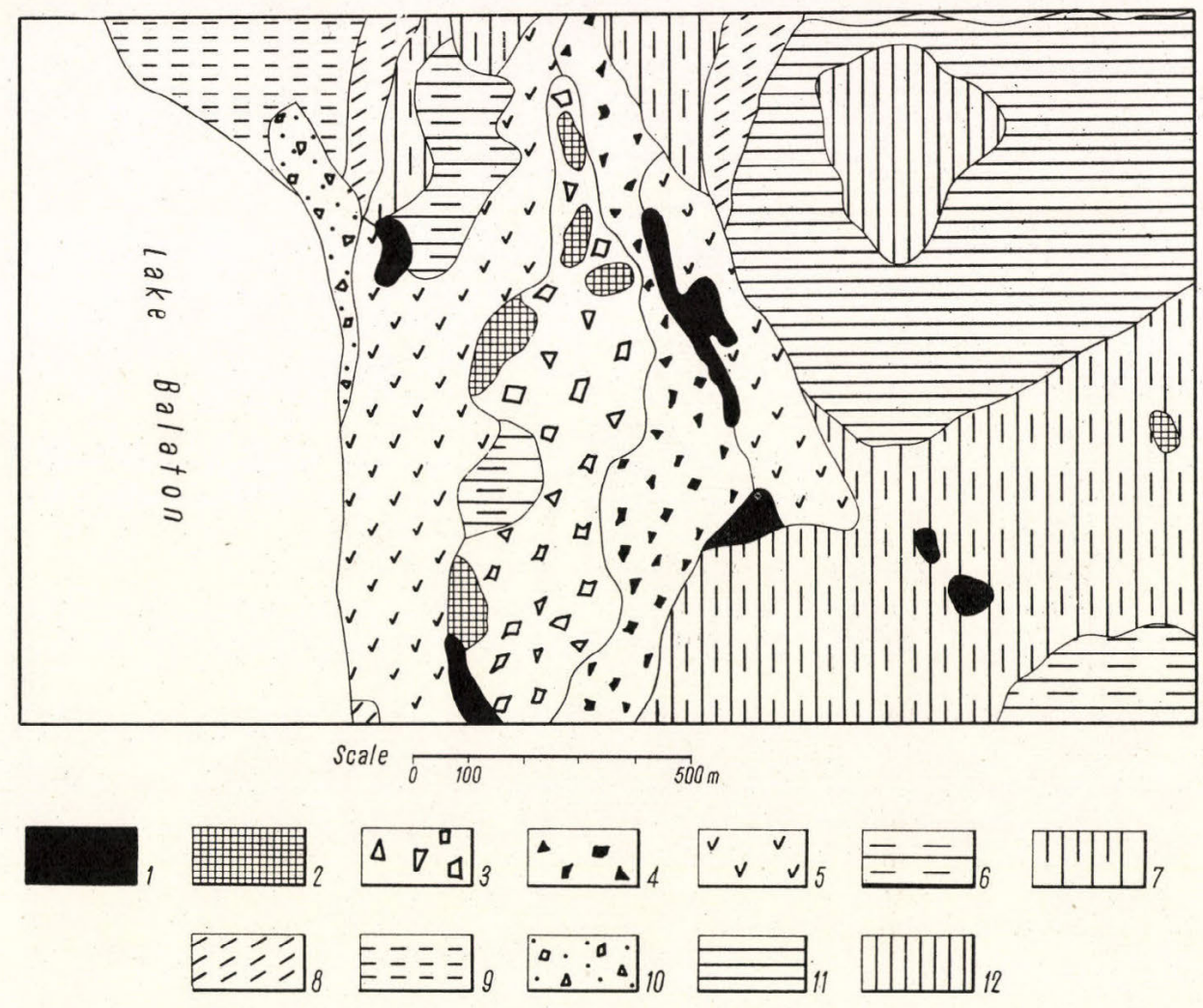

Fig. 1. The map of the soil bearing rocks, Tihany Peninsula. 1. Bedded basalt tuff. 2. Siliceous calc-tuff (tufa). 3. Calc-tuff detritus overlying basalt tuff. 4. Thin deluvium with debris of basalt tuff. 5. Loess-like loamy deluvium forming a thin cover on basalt tuff. 6 . Deluvium covering the basalt tuff, with variegated clay and basalt tuff debris. 7 . Calcareous loam of Upper Pannonian age. 8. Slope-deposited loess. 9. Calcareous inundation silt. 10. Barrierbeach sand with debris. 11. Grey calcareous bog silt. 12. White calcareous bog silt

The legend designed for the $1: 25,000$ scale morphological maps of the Geographical Research Institute of the Hungarian Academy of Sciences provides a standard.

The observation density of field surveying furnishes the basis for mapping and depends on the measure and the forms of erosion, and on the precision of the details shown by the geological map sheet which is to be revised. This latter point may be verified during the field work only (Fig. 1). 


\subsection{Maps of slope categories}

The notion of "slope categories" has been introduced in Hungary in order to unite the given physico-geographical conditions of a slope with the agrotechnical demands of soil conservation, because from the point of view of the latter not only the morphological elements of the slope (its convex, straight and concave facets), its angle, length, degree of dissection, aspect and evolution must be evaluated, but also the agrotechnics to be applied to it (Erödi and Horváth 1965).

In order to provide a firm scientific basis for soil protection, the map of slope categories has to contain valid data about the areas concerned. Even the $1: 25,000$ scale topographic maps are not detailed enough for a sufficiently precise categorization of slopes, especially in the case of steep ones. Therefore it is recommended, if there are no sheets at a scale of $1: 10,000$ available, to enlarge the $1: 25,000$ scale topographic sheets of the catchment area or the microlandscape to a scale of at least $1: 10,000$ or $1: 5,000$, by means of a stereoscope, epidiascope or a pantograph.

On a photostatic copy of this enlarged map, slope categories may be designed in the office. This initial manuscript must then be corrected in the field, by determining and delimiting slope facets of different evolution and those of southerly aspect. This map serves as a basis for rethinking cultivation and for regrouping of land into the most suitable units for soil conservation. If the map has been drafted for the purposes of a "directive project", it may be reduced again to a scale of $1: 25,000$.

The resulting map of slope categories will differ in two essential ways from those plotted before.

1. It demonstrates for every slope category those facets of the slope that are growing, those that are relatively stable, and those that are being destroyed. These are distinguished and delimited by means of field surveying in the field the maps of slope morphology and soil bearing rocks. The importance of this work cannot be overemphasized.

2. It points out those parts of the slope which are of southerly aspect and which are particularly liable to drought because of their exposure to maximum insolation (Stefanovits 1964, Góczán 1966).

Helping water to penetrate the soil in such areas constitutes an outstanding task of soil conservation. Soils of southerly aspect are divided into three strips. As is generally known, efficiency of insolation decreases as aspect changes from a southern, southwestern through to a southeastern direction. The distinction of slope categories on the map is obviously well founded, because slopes of southerly aspect must be treated differently, as far as agricultural techniques are concerned for soil conservation.

On the map, gullies, ravines and artificial terraces are to be treated from the point of view of soil protection as well (Fig. 2).

\subsection{APPLIED SOIL GEOGRAPHY IN THE SERVICE OF SOIL CONSERVATION}

Protection against soil erosion is based upon a knowledge of the natural conditions of the slopes of an area, acquired by scientific analysis. The geo- 

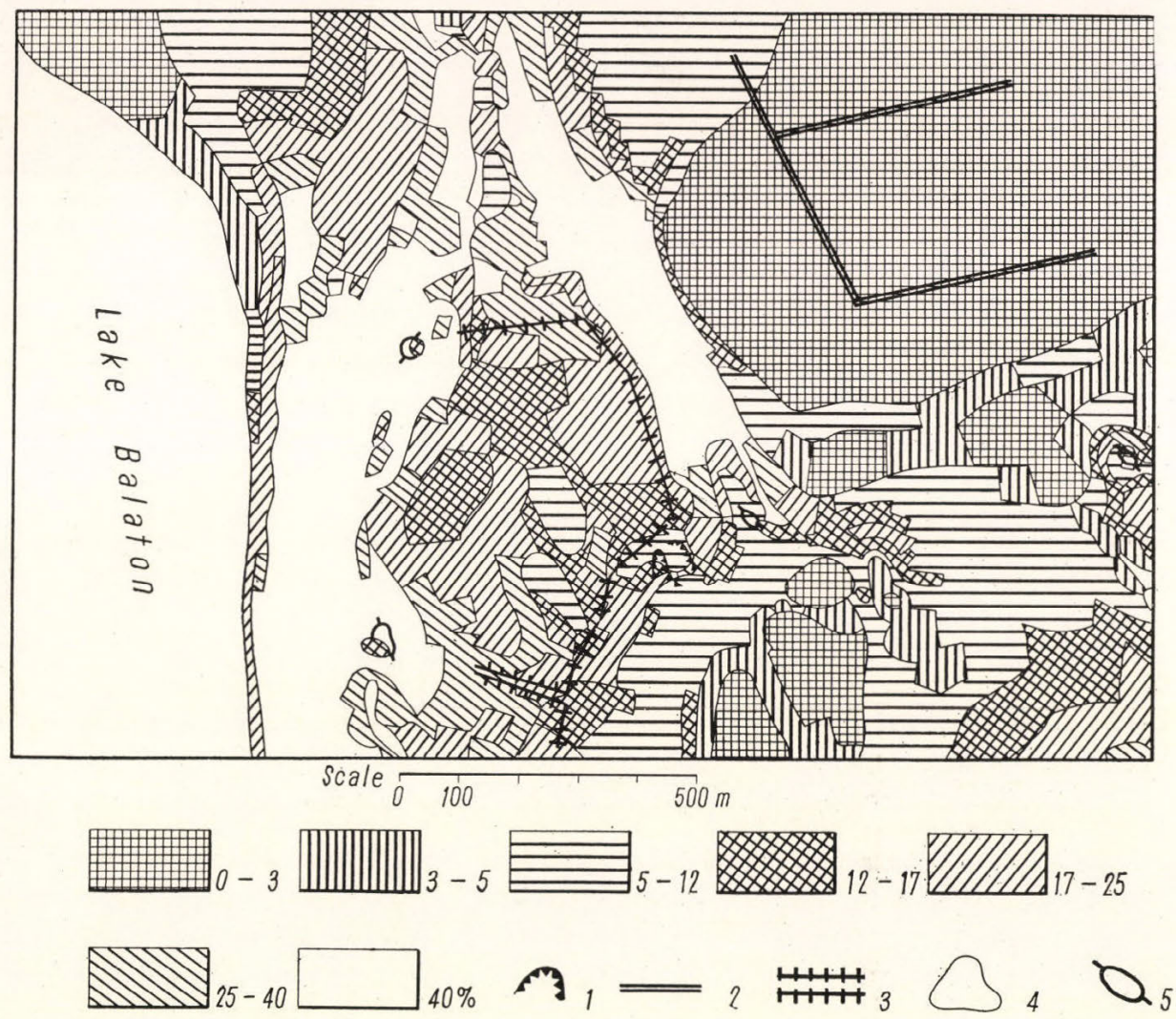

Fig. 2. Map of slope categories, Tihany Peninsula. 1. Quarry. 2. Canal. 3. Artificial terrace sand wall, resp. filling. 4. Boundary of slope categories. 5. Crest, peak

morphological aspect of this knowledge is furnished by the maps of soil-bearing rocks and slope categories (Góczán, L. 1966, p. 340).

These two maps demonstrate the natural conditions which determine whether, as a result of the interaction between the soil cover, the slope area and the destructive forces, the soil suffers a certain degree of erosion, or it is being covered with deluvia.

Both the investigation of the dynamics of soil destruction and the mapping of its state at a given time are tasks for applied soil geography.

\subsection{Applied genetic soil map}

In order to discover the laws of soil destruction, the grade of soil erosion must be surveyed and shown on a map. This provides a convenient starting point. 
Mapping soil erosion is carried out by means of the areal determination and representation of genetic soil types, down to the level of "erosion" varieties.

With regard to this, the author proposes to prepare genetic soil maps of the slope regions, on which soil varieties are distinguished. Since the degree of erosion observable in the soil profile is one of the criteria of soil variety on sloping surfaces, the genetic soil map would also be a map showing the areal distribution of soil erosion.

The two extreme cases are non-eroded intact soil and skeletal soil. Between these extremes, three varieties exist.

1. A lightly eroded variety (the A horizon is thin in comparison with the complete section).

2. An average eroded variety (the B horizon outcrops but is practically untouched by erosion).

3. A strongly eroded variety (only thin remnants of the B horizon are left).

This classification relates to forest soils. In the case of chernozems, where the $\mathrm{B}$ horizon is relatively thin, the varieties are somewhat different. If the B horizon of a black earth outcrops, the soil is strongly eroded. The disappearance of one third of the A horizon characterizes the lightly eroded variety, and when two thirds are missing the soil is said to be of average eroded variety.

This representation of soil destruction differs essentially from the method previously used (Mattyasovszky 1957a, Duck 1960, Stefanovits 1962, 1964).

Beside those described above, two further varieties are illustrated: (1) the incomplete chestnut forest soil covered by slope debris, (2) the humified incomplete chestnut forest soil.

Soil destruction by deflation prevails where the soils are sandy, especially those developed on blown-sand, and for soils developed on narrow edges exposed to the wind regardless of the parent material. A distinction between deflated soil varieties may be made in a similar way to that described above for soils eroded by water.

Symbols showing the degree of destruction are included in the legend (Fig. 3).

The deposition sites of materials derived from soil destruction are to be delimited partially as areas characterized by slope soil deluvia. The areal distinction of these is most necessary because a deluvial, redeposited humus of any thickness accumulated on a slope is never equivalent to a soil developed in situ. It lacks a coherent pore system: its water, heat and air balances differ from those of a natural soil, as does its biological activity. As a consequence of all these, the availibility of plant nutriants, which determines its fertility, will differ as well.

Beside "soil deluvia", alluvial soils of valley bottoms are to be discerned. These may be derived from soils, or in a case of more intensive soil destruction from loose sediments, or even from both. They differ from each other on such points as water pressure, excessive moisture content, etc.

The detailed genetic soil map, at a scale of at least $1: 10,000$, may be plotted on the basis of the evaluation of cross sections and bore holes at convenient intervals (depending on the given local conditions), and of laboratory analyses of soil samples. 


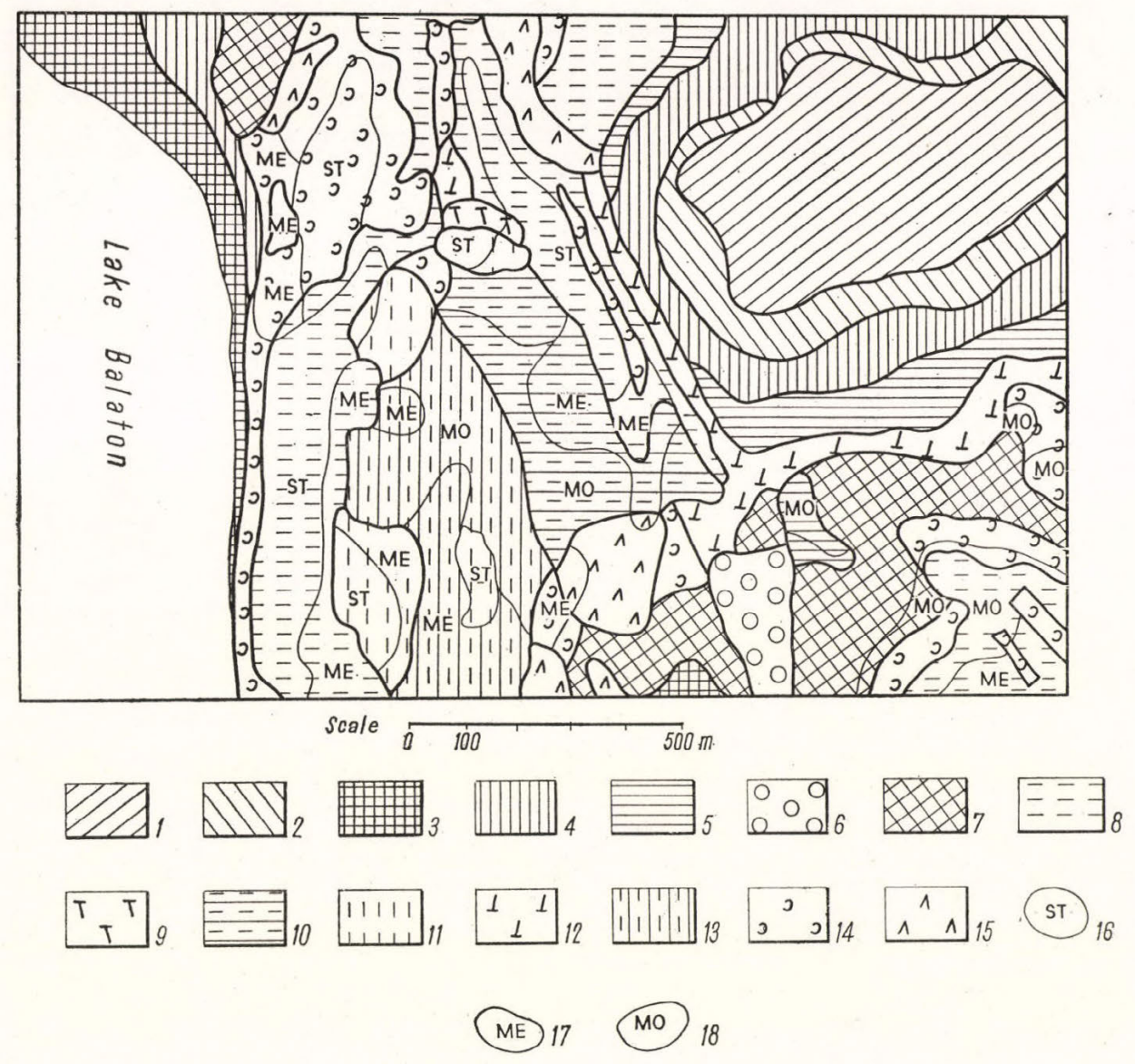

Fig. 3. Applied genetic soil map, Tihany Peninsula. 1. Plain bog soil. 2. Boggy meadow soil. 3. Meadow soil. 4. Steppe-like meadow soil. 5. Meadow chernozem. 6. Rock-effected chernozem on the slope deluvium of loess-loam. 7. Rock-effected chernozem chestnut forest soil. 8. Black loess-loam on basalt tuff. 9. Loess-loam slope deluvium on basalt tuff debris. 10. Cultivated variety of black loess loam. 11. Black rendzina on siliceous calc-tuff. 12. Rendzina slope deluvium on calc-tuff debris. 13. Cultivated variety of black rendzina. 14 . Humus carbonate soil on a thin loess-like cover. 15. Earthy barren surface. 16. Strongly eroded soil variety. 17. Average eroded soil variety. 18. Lightly eroded soil variety

The genetic soil map obtained in this way and the great number of field observations and laboratory data enable the construction of several cartograms (Várallyay 1950, Jassó 1961, Romlehner-Nagy 1963, Sarkadi, Szücs and Várallyay 1964) which demonstrate the actual state of soil destruction and permit an estimate of the damage caused.

Such cartograms are: 


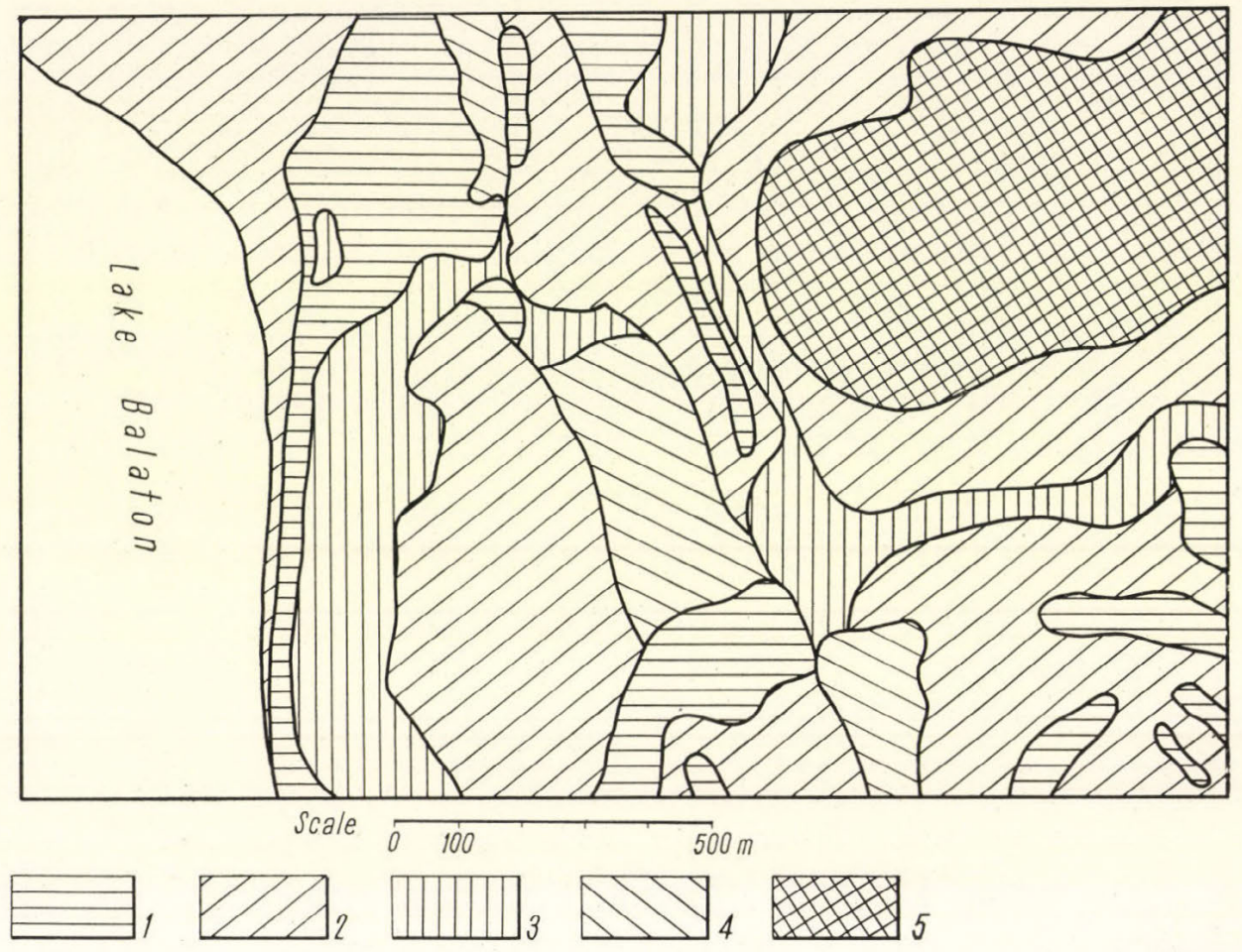

Fig. 4. Total N percentage nutrient cartogram, Tihany Peninsula. $1=1.0-0.15 ; 2=$ $=0.15-0.20 ; 3=0.20-0.25 ; 4=0.25-0.30 ; 5=0.30$

1. Humus cartogram, showing the thickness of the humus layer and the humus percentage in the surface soil.

2. Cartograms of the reserve of nutrient materials (Figs. 4, 5, 6). On the basis of the N, P and K content furnished by laboratory analyses, separate cartograms may be designed for each of these (Sarkadi, Szücs and Várallyay 1964). For this purpose, literature data may be used as well.

3. The cartogram of the amount of lime to be used for soil amelioration (Góczán 1966), may be drawn up on the basis of acidity values. Naturally, slope categories must be taken into consideration, because they effect the efficiency of liming. At present, small applications are recommended in the case of slopes (Erődi, Horváth, Kamarás, Kiss and Szekrényi 1965).

4. Cartogram of physical soil characteristics (Jassó 1961). This may be compiled using the data of mechanical analysis, with regard to the data furnished by the literature. Used in conjunction with the map of soil-bearing rocks, it reveals the possibilities of cultivation.

If needed, several more cartograms may be designed (Szabolcs 1966).

All laboratory data used during the preparation of the genetic map are attached to it in the form of a table accompanied by a concise explanatory text. 

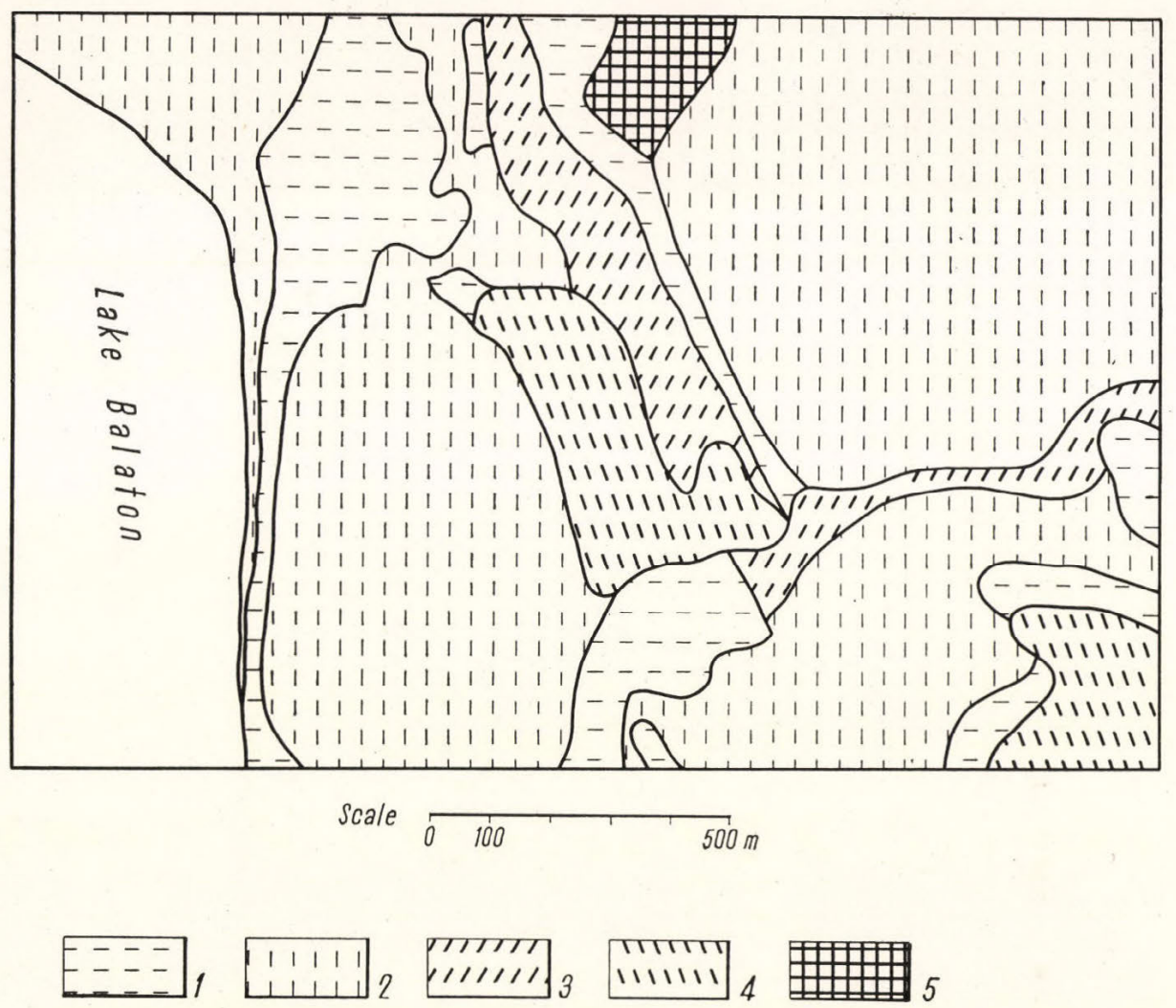

Fig. 5. Easily soluble $\mathrm{P}$ content $\left(\mathrm{P}_{2} \mathrm{O}_{5} \mathrm{mg} / 100 \mathrm{~g}\right)$ nutrient cartogram, Tihany Peninsula. $1=0-5 ; 2=5-10 ; 3=10-15 ; 4=15-20 ; 5=30-50$

What has been described above constitutes the first group of soil geographical investigations for the purpose of soil conservation, including the distinction of the various soil types, the evaluation of their respective states of destruction, and an appropriate illustration of the data obtained in the course of this work.

\subsection{Investigation of the dynamics of soil destruction}

The registration of the recent state of soil erosion serves as a starting base for the study of the dynamics of soil destruction. This is an indispensable condition for successful soil conservation.

The second type of applied soil geographical research in the service of soil conservation consists of research work on the dynamics of soil destruction itself. 


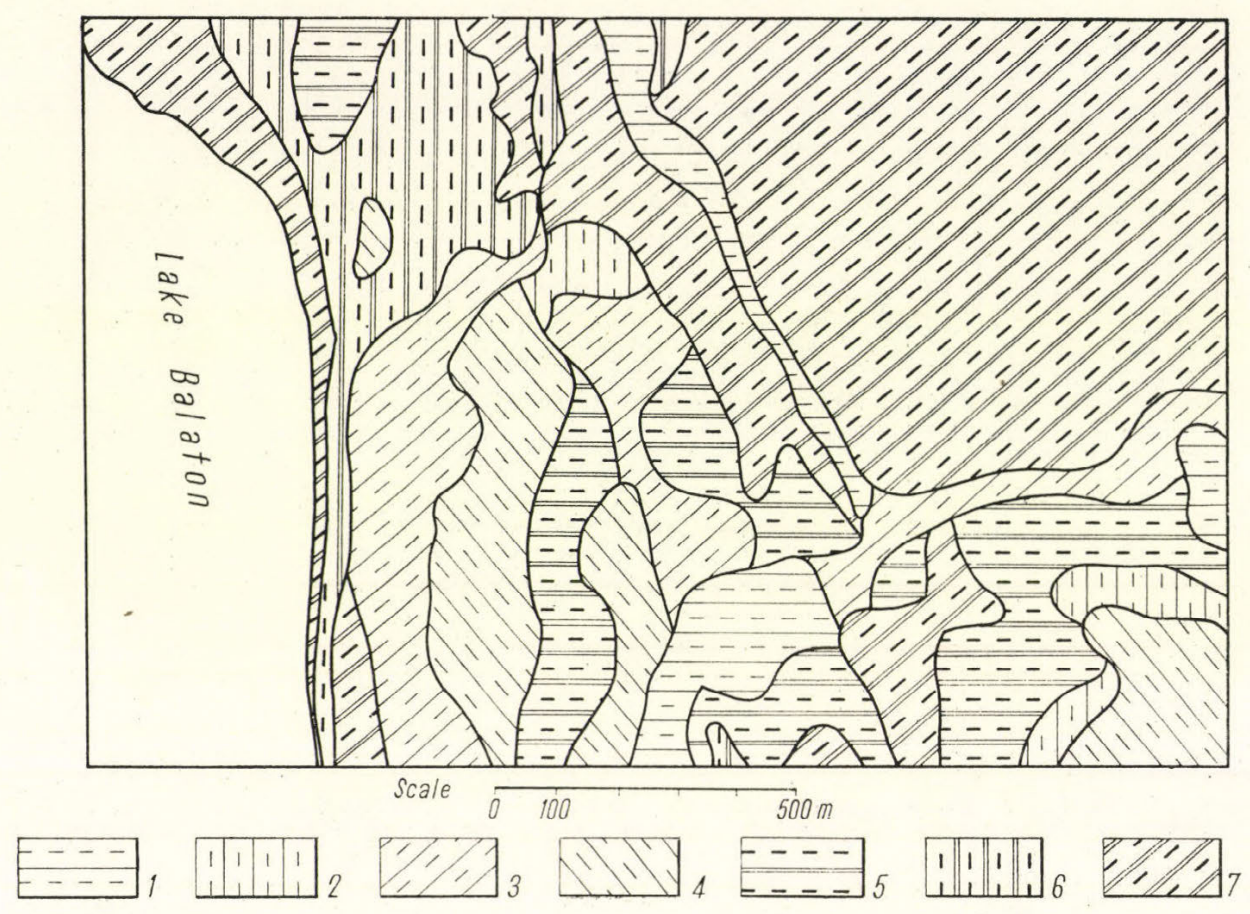

Fig. 6. Easily soluble $\mathrm{K}$ content $\left(\mathrm{K}_{2} \mathrm{O} \mathrm{mg} / 100 \mathrm{~g}\right)$ nutrient cartogram, Tihany Peninsula. $1=5-10 ; 2=10-15 ; 3=15-20 ; 4=20-25 ; 5=25-30 ; 6=20-50 ; 7=50-100$

The dynamics of soil destruction is essentially the interaction between the destructive forces (active factor) and the soil (passive factor).

The components of the soil destruction process are to be investigated in relation to this interaction.

A. The passive factors are:

1. The characteristics of the water balance in the soil: soaking, field capacity and permeability, which depend on differential porosity and the nature of the clay minerals and humus.

2. The erodibility of the soil, i.e. the facility with which the original soil grains separate from the aggregate soil mass, and the transportability of the separate particles. These peculiarities depend on the mechanical composition and structure of the soil (Di Gléria, Klimes-Szmik and Dvorácsek 1957). The latter are genetically determined (quality of the humus), but they depend on cultivation as well.

3. The moisture state of the soil.

4. Vegetation cover. 


\section{B. The active factors are:}

5. The amount, intensity, and form of precipitation penetrating into the soil and running off its surface.

6. Quality, form and aspect of the slope.

7. Direction, speed and frequency of winds during those seasons of the year which are deprived of vegetation (Stefanovits 1963a).

What is to be done in order to elucidate this interaction-with regard to the urgent measurements of soil conservation which are made necessary by the increase in soil erosion and by the decrease in the reserves of nutriants? In this respect the following tasks are to be performed by applied soil geography.

2.221. Investigation of the water balance in soils on sloping surfaces

This work includes field and laboratory investigations to be executed under the following conditions.

1. In a given landscape, on a determined genetic type of soil derived from the same parent material, in a consolidated state of cultivation, on different slope categories.

2. The same as above, only in a fresh state of cultivation instead of a consolidated one.

Thus a series of water balance types may be obtained in each landscape for all soil types to be found on slopes and for different slope categories. This series may be evaluated by itself or by comparison with others. The succession of areas to be examined will be determined by soil conservation projects, which are adapted, in their turn, to the measure and intensity of soil destruction.

The work to be done in the field and in the laboratory is as follows:

a. To determine for samples taken specially for this purpose from every genetic zone, the specific and volumetric weights, the different water capacity values, the differential and total porosity and the moisture content.

b. To determine, on the spot, by Kazó's artificial rain method, the natural water capacity, the permeability values for different intensities, and the runoff values for different intensities and water masses. Thus the infiltration/runoff ratio may be obtained as a function of slope angle (Kazó 1966).

c. The quantity and intensity of precipitation are measured on the spot by an ombrograph, simultaneously with the above described field and laboratory investigations.

d. The quantities of precipitation, runoff and eroded soil are measured in an exposed tank (Stefanovits 1962).

The water content of the rained-over soil is measured, preferably after rain, by means of a dampness measuring device working on the principle of neutron scattering. This and the water collected in the tank are compared with the data furnished by the ombrograph. The evapo-transpiration values may also be obtained directly by this method. 


\subsection{Erodibility and destruction}

The data furnished by the qualitative and quantitative analyses of the soil deluvia that was caught in the tank under well defined conditions of slope, soil and precipitation, are compared with the erodibility values. Thus a valuable control material is obtained about the dynamics of soil destruction.

The steps in the technique are as follows.

1. The mass of the eroded soil is determined and its weight and percentage volume is given.

2. Its mechanical composition is examined and compared with the data of the volumetric and mechanical composition of the soil in the eroded area.

3. Qualitative and quantitative humus analyses are made on the samples of both the original and eroded soil, and the results are compared.

4. Aggregate analysis is performed on both types of sample and they are compared (Di Gléria, Klimes-Szmik and Dvorácsek 1957).

5. The original and eroded samples are submitted to detailed mineralogical (including DTA) and chemical analyses.

6. Unit volume samples of the original and eroded soil are subjected to qualitative and quantitative nutrient tests ( $\mathrm{N}, \mathrm{P}, \mathrm{K}, \mathrm{Mg}$ ). Having made these analyses during the vegetation-less season at given time intervals, one evaluates them for each year in order to determine the annual rate of denudation. It is evident that the dynamics and speed of soil destruction may be judged reliably on the basis of all these data.

The soil destructive action of wind requires the investigation of fewer factors, and consequently, the mechanism of wind deflation is already sufficiently well known (Mrs Bodolay, 1965). The soil destructive effect of wind is to be examined in places characterized by high wind frequency and considerable force. Only turbulent and intermittently gusting winds contribute to deflation. The synchronized application of a soil-catcher and a wind speedometer seems to be the most suitable way to determine the efficiency of deflation. The minimum speed required for blowing away from the surface particles of 0.1 to $0.15 \mathrm{~mm}$ diameler-which are the easiest to transport-is 12.8 to $14.4 \mathrm{~km}$ per hour. By fractionation of the wind-blown particles caught, it is possible to determine the degree of deflatability of a given genetic soil type as a function of wind strength, in the cases of a soil surface

(a) without vegetation,

(b) freshly cultivated,

(c) consolidated (Fekete, Hargitai and Zsoldos 1964).

The effect of wind on soil destruction can be studied by means of other, more complicated methods as well (Chepil 1941, 1943, 1945, 1950).

On the basis of the research enumerated above, soil geography applied to protection against soil destruction is capable of producing a scientifically founded opinion for the use of soil conservation projects. 
2.23. Soil geographical investigations about the disposition of southerly exposed slopes to drought

Another problem is-beside the struggle carried on against soil destruction on slopes-is the protection of southerly exposed slopes against drought (Stefanovits 1964, Góczán 1966). The very fact, that a slope of this kind receives more thermal energy in comparison with plain surfaces in its surroundings or slopes of different aspects, and that the water balance of these slopes always shows a deficit, leads automatically to drought.

On such surfaces drought contributes to the decrease in fertility provoked by soil destruction.

The combination of these two pernicious effects on soils of southerly aspect is revealed by their elevated rates of evaporation of the infiltrated water. In fact, it may be stated that the worst water balance is found on soils situated on slopes of southerly exposure.

In such cases one has to increase the penetration of water into the soil. This is a duty of agronomy and engineering. But it requires a multilateral knowledge of the soils in question, which can be obtained from the above described investigations. For this reason the soil and the moisture, as two components of the inclination to drought, may be considered as already known.

The factors of heat and air circulation remain to be discussed.

Air circulation on surfaces of different aspect scarcely differs from that on the plain ones. The heat factor, however, exhibits very remarkable differences.

It is a generally known fact that an area with variated relief receives much less heat than a plain surface of such extension as would cover the former from the sun, owing to the fact that the same amount of irradiation is absorbed by a larger surface in the former than in the latter case. For this reason, in regard to irradiation, an area of high relief energy is always of larger surface than the plain surface that would exactly cover it. The radiation balance, i.e. the thermal economy or household is on the whole more in deficit in a hilly area than on a plain. This influences not only the climate in general, but the soil climate especially.

However, if one considers slopes of southerly aspect only, the relation to the plain surface turns out to be just the inverse. A slope of southerly aspect absorbs a greater amount of solar energy, since one surface unit of it receives more irradiated energy than that of the plain surface in relation to which the rays of the sun have a smaller angle of incidence. This surplus of warmth is more considerable if compared with the heat absorbed by a slope of any other than southerly aspect. This is why significant differences exist between slopes of different aspect even in the case of small hills.

In order to determine the degree or measure of being disposed to drought of the various genetic soil types on slopes of different length and angle, the heat balance of the soils on the slopes of southerly aspect must be known. This knowledge is required for choosing the proper agrotechnical and engineering method to facilitate the penetration of water into the soil.

(Southerly aspect has naturally a number of advantages, too. For example, more energy is available for assimilation. This surplus of radiation energy creates natural conditions-if the properties of the soil are otherwise con- 
venient-suitable for viticulture and fruit-growing. This problem is, however, beyond the aim of soil geography applied to the service of soil conservation.)

The proposal is made that the above emphasized point should be added to the usual items of research tasks which are generally to be performed concerning the "natural conditions" of soil conservation.

\section{SUMMARY}

Applied soil geography possesses an independent domain of investigation and a method of its own. Its research tasks may be divided into two groups.

I. Research into natural soil improving materials, their exploitation, classification, mapping and calculation of available reserves.

II. Research to lay the scientific foundation of soil conservation:

(a) Surveying and construction of the map of soil-bearing rocks.

(b) Drawing up the map of slope categories.

(c) Surveying and preparing of the applied genetic soil map.

(d) Designing cartograms to demonstrate the various soil properties.

(e) Research into the dynamics of soil destruction, which is subdivided into:

(1) the examination of the water balance of soils developed on slopes and

(2) erodibility and denudation studies.

(f) Investigation of the disposition to drought of the slopes of southerly aspect.

The question may arise: why are these investigations considered a part of applied soil geography? The answer is obvious: they can be tackled in the most successful and economical way only with the help of an all-round knowledge of the strictly determined geographical conditions of genetic soil types.

\section{REFERENCES}

Aujeszky, L., Berényi, D. and Béll, B. (1951): Mezögazdasági meteorológia (Agricultural meteorology). Budapest: Mezőgazd. Kiadó.

Bacsó, N. (1958): Bevezetés az agrometeorológiába. (Introduction to agrometeorology). Budapest: Mezőgazd. Kiadó.

Bánky, Gy. (1959): Kisnánai eróziómérô állomás háromévi munkásságának eredményei (The results of three years' work at the Erosion Measuring Station at Kisnána). Erdészeti Kutatások, Vol. 55, pp 139-164.

Bennett, H. H. (1947a): Elements of Soil Conservation. New York: McGraw-Hill.

Bennett, H. H. (1947b): Our American Land. The Story of its Abuse and its Conservation. U. S. Dep. of Agric.

Bodolay, I., Mrs (1965a): Szélerózió elleni védekezés öntözött homokterületeken (Protection against wind erosion in irrigated sandy areas). Agrokémia és Talajtan Vol. 14.

Bodolay, I., Mrs. (1965b): A szélerózió folyamata és dinamikája (The process and dynamics of wind erosion). Agrokémia és Talajtan, Vol. 14.

Bodolay, I., Mrs (1966a): A talajművelés szerepe szélerózió fellépésében (The role of soil cultivation in wind erosion). Agrokémia és talajtan, Vol. 15

Bodolay, I., Mrs (1966b): A széleróziót befolyásoló talajfizikai tulajdonságok (Physical soil properties that influence wind erosion). Agrokémia és Talajtan, Vol. 15. 
Chepil, W. S. (1950-1951): Properties of Soil which Influence Wind Erosion. I-IV. Soil Science.

Chepil, W. S. (1955): Factors, what Influence Clod Structure and Erodibility of Soil by Wind. IV-Sand, silt and clay. Soil Science

Chepil, W. S. (1956): Influence of Moisture on Erodibility of Soil by Wind. Soil Science Society of America-Proceedings.

Chepil, W. S., Woodruff, N. P., Siddoway, F. H., Fryhear, D. W. and Ambrust, D. V. (1963): Vegetative and Nonvegetative Materials to Control Wind and Water Erosion. Soil Science Society of America-Proceedings.

Duck, T. (1960a): Magyarország dombos vidékeinek eróziós térképe (Erosion map of Hungary's hilly areas). Agrártudomány, Vol. 12.

Duck, T. (1960b): Eróziós területek térképezése és értékelése (Mapping and evaluation of erosion areas). MTA Agrárludományi Osztály Közleményei, Vol. 9.

Duck, T. (1960c): Néhány barna erdótalajtípus erózióval szembeni viselkedése (The behaviour of some types of chestnut forest soil in relation to erosion). Agrokémia és Talajtan, Vol. 9.

Duck, T. (1962): Csapadékviszonyok hatása a talajerózióra. Alkalmazott éghajlattani kutatások Délkelet-Dunántúlon (The effect of precipitation on soil erosion. Applied climatological research in NE Transdanubia). Magyar Meteorológiai Társaság.

Duck, T. (1964): Talajerózió vizsgálata barna erdőtalajon kisparcellás kísérletekben (Investigation of soil erosion on chestnut forest soil by means of experiments on small parcels of land). MTA Agrártudományi Osztályának Közleményei, Vol. 13.

Egerszegi, S., Fekete, Z., Göncz, A. and Mattyasovszky, J. (1954): A komplex talajvédelem kérdései (Problems of complex soil protection). Kertészeti és Szólészeti Fóiskola Éskönyse.

Erödi, B. (1965): A talajvédelem helyzete Magyarországon (The status of soil conservation in Hungary). Vizgazdálkodás, Vol. 5.

Erődi, B. and Horváth, V. (1960): Az erózió és talajvédelem jelentősége (The significance of erosion and soil conservation). Magyar Mezógazdaság, Vol. 15.

Erődi, B. and Szekrényi, B. (1959): Erózió és talajvédelem (Erosion and soil conservation). Mezögazdasági Világirodalom.

Erődi, B., Klimes, and Szmik, A. (ed.) (1963): A szárazföldi erózió problémái (Problems of dry land erosion). Országos Mezőgazdasági Könyvtár és Dokumentációs Központ, Budapest.

Erődi, B. and Horváth, V. (1965): Talajvédelmi célú lejtőkkategória térképek szerkesztése (The preparation of slope category maps for soil conservation). Geodéiza és Kartográfia, Vol. 17.

Erődi, B., Horváth, V., Kamarás, M., Kiss, A. and Szekrényi, B. (1965): Talajuédö gazdálkodás hegy-és domboidéken (Soil conservating cultivation on hilly and mountainous regions). Budapest: Mezőgazdasági Kiadó.

Fekete, Z. (1952): Talajtan (Soil science). Budapest: Mezőgazd. Kiadó.

Fekete, Z. (1953): Küzdelem a szántóföldet sújtó talajerózió ellen (The struggle against soil erosion on arable land). Agrártudomány, Vol. 5.

Fekete, Z. (1954): Talajvédelem (Soil conservation). Budapest. Mezőgazd. Kiadó

Fekete, Z. (1958): Talajtan és trágyázástan (Science of soil and fertilizers). Budapest. Mezőgazd. Kiadó.

Fekete, Z. (1964): A termőtalaj védelme (The protection of fertile soil). Budapest. Mezőgazd. Kiadó.

Fekete, Z., Hargitai, L. and Zsoldos, S. (1964): Talajtan és agrokémia (Soil science and agrochemistry). Budapest.

forestry). Erdögazdaság és Faipar.

Góczán, L. (1965): A tájkutatás talajföldrajzi feladatai (Soil geography and landscape research). Földr. Ert.. Vol. 14.

Góczán, L. (1966): A Marcal-medence talajföldrajza (The soil geography of the Marcal Basin). Dissertation for Candidature, Budapest.

Góczán, L., Marosi, S. and Szilárd, J. (1954): Adalok a kőzetminőség, az erózió és a tektonikus mozgások jelenleg ható felszínformáló szerepéhez, valamint a talajerózióhoz (Contributions to the recent surface-modelling role of the nature of rock, erosion and tectonic movements and to soil erosion). Földr. Ert. Vol. 3.

Gottschalk, L. (1963): A vízgyújtő védelem eljárásainak hatása az erózió és a hordalékokozta károk csökkentésére az Északamerikai Egyesült Államokban (The effect of catchment area protecting measures upon the damage caused by erosion and alluvia, in the U.S.A.). In: Erödi-Klimes-Szmik (eds): A szárazföldi erózió problémái (Problems of dry land erosion). Budapest: $\mathrm{OMgK}$. 
Jassó, F. (1961): A besenyszögi "Erdei" Termelöszövetkezet genetikus üzemi talajtérképe (The genetic soil map for farming purposes of the "Erdei" Farmers' Cooperative in Besenyszög). publ. by OMMI, ser. I. No. 2., Budapest.

Juva, K. and Cablik, J. (1954): Protierosni ochrana pudy (The protection of soil against erosion). Praha: Statni zemedelske nak.

Kakas, J. and Szepesiné, Lőrincz, A. (1963): Éghajlatunk vízháztartási kérdései (Problems of water balance under our climate). Időjárás, Vol. 67.

Kazó, B. (1960): Talajeróziós kutatások izotópjelzés segítségével (Soil erosion research by the application of marking isotopes). Agrokémia és Talajtan, Vol. 9.

Kazó, B. (1966a): Eróziós talajvizsgálati módszerek (Methods of soil erosion research). Agrokémia és Talajtan, Vol. 15.

Kazó, B. (1966b): A talajok vízgazdálkodási tulajdonságainak meghatározása mesterséges esốztető készülékkel (The determination of the water economy properties of soil by an instrument producing artificial rain). Agrokémia és Talajtan, Vol. 15.

Kiss, A. (1962): Talajvédelmi tereposztályozás (Classification of terrains in the service of soil conservation). Magyar Mezögazdaság, Vol. 17.

Kostyakov, A. N. (1955): A melioráció alapjai (Principles of amelioration), Budapest. Mezôgazd. Kiadó.

Kreybig, L. (1956): Az agrotechnika tényezői és irányelvei (The factors and directives of agrotechnics). Budapest. Mezőgazd. Kiadó.

Kund, E. (1941): A termóföld pusztulása és megvédése (Destruction and protection of arable Land). Term. Tud. Társ. Közl. Vol. 72

Lopatin, G. V. (1963): A víz okozta erózió intenzitása a Szovjetunió területén (The intensity of water erosion in the USSR). In: Eródi-Klimes-Szmik (eds): A szárazföldi erózió problémái (Problems of dry land erosion). Budapest. $\mathrm{OMgK}$.

Lovász, Gy. (1965): A reliefenergia új ábrázolása (A new method of relief energy illustration). Földr. Ért., Vol. 14.

Maran, B. (1960): A talajvédelem Csehszlovákiában (Soil conservation in Czechoslovakia). Nemzetközi Mezögazdasági Szemle, Vol. 4.

Mattyasovszky, J. (1953a): Talajok vízáteresztő képességének vizsgálata és a vizsgálat eredményeinek alkalmazása a talajvédelemben (The investigation of the permeability of soils and the application of its results to soil conservation). Agrokémia és Talajtan, Vol. 2.

Mattyasovszky, J. (1953b): Északdunántúli talajok eróziós viszonyai (The erosion conditions of soil in NW Transdanubia). Agrokémia és Talajtan, Vol. 2.

Mattyasovszky, J. (1956): A talajtípus, az alapkôzet és a lejtôviszonyok hatása a talajeróziós folyamatok kialakulására (The effects of soil type, parent material and slope upon the development of soil erosion processes). Földr. Közl. Vol., 4 (new series).

Mattyasovszky (1957a): Az erózió térképezésének kérdése és eddigi eredményei (The problems and results of erosion mapping). MTA Agrártudományi Osztályának Közleményei, Vol. 6.

Mattyasovszky, J. (1957b): Felületi elfolyóvizek keletkezése és az erózió (The origin of running off water and erosion). MTA Agrártudományi Osztályának Közleményei, Vol. 6.

Mattyasovszky, J., Duck, T. (1954): Az erózió hatása a talajok tápanyagviszonyaira (The effect of erosion upon soil nutrients). Agrokémia és Talajtan, Vol. 3.

Mazurak, E. P., Zing, A. W. and Chepil, W. S. (1953): The effect of 39 years of cropping practices on wind erodibility and related properties of an irrigated chestnut soil. Soil Sci. Soc. Amer. Proc.

Motoc, M. and Trasculescu, Fl. (1960): Talajpusztulás-talajvédelem a mezógazdaságiterületeken (Soil destruction and soil conservation in agricultural districts). Bucharest: Mezőgazd. és Erd. Áll. K.

Norton, E. A. (1939): Soil Conservation Survey Handbook. Washington. U.S. Dep. of Agric.

Pécsi, M. (1962): A magyarországi pleisztocénkori lejtôs üledékek és kialakulásuk (Pleistocene slope sediments in Hungary and their formation). Földr. Ért., Vol. 11.

Pécsi, M. (1963): A magyarországi geomorfológiai térképezés az elmélet és a gyakorlat szolgálatában (Geomorphological mapping in Hungary in the service of theory and practice). Földr. Közl. Vol. 11 (new series).

Pécsi, M. (1965): A magyarországi lejtólöszök, talajüledékek és azok kialakulásának problémái (Hungarian slope loesses, soil sediments and the problems of their formation). Agrokémia és Talajtan, Vol. 14.

Péczely, Gy. (1963): A helyi éghajlati zónák kijelölésének néhány kérdése (Some problems of the determination of local climatic zones). Időjárás, Vol. 67. 
Romlehner, L. and Nagy, L. (1963): A városlődi állami gazdaság jánföldpusztai üzemegységének genetikus üzemi talajtérképe (A genetic soil map for farming purposes of the Jánföldpuszta Farming Unit of the Városlöd state farm). Publ. by OMMI ser. I. No. 5.

Sarkadi, J., Szücs, L. and Várallyay, Gy. (1964): Nagyléptékü üzemi genetikus talajtérképek (Detailed genetic soil maps for farming purposes). Publ. by OMMI ser. 1. No. 8. Budapest.

Schultze, J. (1953): Neue theoretische und praktische Ergebnisse der Bodenerosion-Forschung in Deutschland. Forschungen und Fortschritte, Vol. 27.

Seginer, I., Morin, J. and Schachori, A. (1963): Felszini elfolyási és eróziós vizsgálatok Izrael egy hegyvidéki, terra-rossa táján (Investigations of surface runoff and erosion in a mountainous "Terra Rossa" landscape of Israel). In: Erödi-Klimes-Szmik (eds): A szárazföldi erózió problémái (Problems of dry land erosion). Budapest; OMgK.

Silvestrov, S. (1963): Az erózió elleni küzdelem földrajzi alapjai (The geographical basis of the struggle against erosion). In: Erődi-Klimes-Szmik (eds): A szárazföldi erózió problémái (Problems of dry land erosion). Budapest:. OMgK.

Sodini, E. (1963): A különleges eljárások keretében folytatott erózió elleni küzdelem DélOlaszországban (The battle against erosion in Southern Italy fought by means of special methods). In: Erődi-Klimes-Szmik (ed.): A szárazföldi erózió problémái (Problems of dry land erosion). Budapest: OMgK.

Stefanovits, P. (1959): A talajföldrajz eredményei és feladatai Magyarországon (Results and tasks of soil geography in Hungary). Földr. Közl., Vol. 7 (new series).

Stefanovits, P. (1962): A talajerózió helyszíni vizsgálata (Examination of soil erosion on the spot). In: Talaj-és trágyavizsgálati módszerek (Investigation methods of soils and fertilizers). pp 145-160. Budapest: Mezőgazd. Kiadó.

Stefanovits, P. (1963a): Magyarországtalajai(The soils of Hungary). Budapest: Mezögazd. Kiadó.

Stefanovits, P. (1963b): A magyar talajeróziós térlépezés alapjai. (The outlines of Hungarian. soil erosion mapping). Budapest: Mezőgazd. Kiadó.

Stefanovits, P. (1964): Talajpusztulás Magyarországon (Soil destruction in Hungary). OMMI ser. 1., No. 8.

Stefanovits, P. (1966): Talajvédelmi tervek talajtani megalapozása (The pedological foundation of soil conservation projects). Agrokémia és Talajtan, Vol. 15.

Stefanovits, P. and Duck, T. (1959): A talajvédelem új lehetősége a termelőszövetkezeti mozgalom új fejlödésével (A new possibility for soil conservation provided by the development of the farmers' cooperative movement). Agrártudomány, Vol. 11.

Stefanovits, P. and Góczán, L. (1962): A Kisalföld magyarországi részének talajföldrajzi viszonyai (The soil geography of the Hungarian part of the little plain). Földr. Közl., Vol. 10 (new series).

Stefanovits, P. and Szücs, L. (1961): Magyarország genetikus talajtérképe (The genetic soil map of Hungary). OMMI.

Szaboles, I. (ed.) (1966): A genetikus üzemi talajtérképezés módszerkönyøe (Methods applied in genetic soil mapping for farming purposes). OMMI ser. 1. No. 9. Budapest.

Szücs, L. (1966): Genetikai talajtérképek szerepe a talajvédelmi tervezéseknél (The role of genetic soil maps in soil conservation projects). Agrokémia és Talajtan, Vol. 15.

Várallyay, Gy. (1950): Üzemi talajtérképek (Soil maps for farming purposes). Agrokémia, Vol. II.

Wheeler, G. (1959): Az Amerikai Egyesült Allamok mezögazdaságának fejlödése és problémái (Development and problems of agriculture in the USA). Budapest: Kossuth Kiadó.

Wischmeier, W. and Smith, D. (1963): A talajveszteség becslése, mint a talajvédelem és a vízvisszatartás tervezésének eszköze (The estimation of soil loss as an instrument of soil conservation and water retainment). In: Erődi-Klimes-Szmil (eds): A szárazföldi erózió problémái (Problems of dry land erosion). Budapest: OMgK.

Yamanlar, O. (1963): A talajerózió osztályozása a régi történelmi országokban és a kilenc esztendős eróziós térképezés eredményei Törökországban (The classification of soil erosion in countries of old historical background and the results of nine-years erosion mapping in Turkey). In: Erődi-Klimes-Szmik (eds): A szárazföldi erózió problémái (Problems of dry land erosion). Budapest: OMgK.

Zing, A. W. and Chepil, W. S. (1950): Aerodynamies of Wind Erosion. Agricultural Engineering. Vol. 41 



\section{DETERMINATION OF WATER HOUSEHOLD PARAMETERS OF SLOPING SOIL SURFACES MEASURED BY THE AID OF A "RAINFALL SIMULATOR"}

by

B. $\mathrm{KA} \mathrm{Z} \mathrm{O}$

Not all of the water arriving at the soil surface in the form of precipitation enters into the metabolic processes of plants: some of it percolates into the ground, the amount depending on the free pore volume available, whereas the rest collects on the surface and runs off downslope. This runoff water is of no advantage to plant life and is positively harmful in that it removes soil particles through the kinetic energy acquired in its movement.

The accessibility of various types of soil to erosion depends, in the first place, on the water household properties. Of these, the most important single one is the intake capacity, which depends on the physical and chemical nature of the soil, on the one hand, and on the cultivation history of the soil, on the other. The water household parameters of soils are not directly comparable because of their differing states of humidity. To permit comparison, it is best to accept as a basic water household parameter the state of saturation to the minimal or free-air water capacity. This is a well-defined state physically, independent of the state of the soil and irrespective of the fact that it corresponds to different absolute moisture contents in different soils.

Once this proposal is accepted, it is possible to add a water-absorption characteristic to the physical and chemical characteristics of soil types. In order that this characterization should not reflect the optimum state of the soil, it is proposed to relate it to soil compacted during one cycle of cultivation.

The above outlined idea of water household characterization required the development of a method suitable for studying the interaction of soil and water under conditions imitating natural ones as far as possible. For this, a rainfall simulator was chosen and constructed. This device is in effect a mobile sprinkling instrument of small water consumption, suitable for studying the runoff and infiltration properties of soils in the field, as well as in the laboratory. Given the amount of precipitation arriving at the soil surface and the accurately measured value of runoff, the water intake capacity can be found as the difference between the two. The Kazó-type rainfall simulator (Kazó and Klimes-Szmik 1962, Kazó 1966) can be used to produce artificial rain closely resembling natural rain, in an intensity range from 20 to 100 millimetres per hour.

$\checkmark$ arying rainfall intensity is necessary because, in erosion research, one must apply the rainfall intensity characteristic of the region, whereas in comparative studies it is best to use a standard intensity of $40 \mathrm{~mm} / \mathrm{hour}$, somewhat exceeding an average storm intensity. On the other hand, in studies prior to irrigation, it is possible to determine, by means of continuously varying the rainfall intensity, the amount of irrigation water necessary; then, again 
using an intensity of $20 \mathrm{~mm}$ per hour, which is the mean output of irrigation sprinklers, will readily yield the necessary duration of irrigation.

The Kazó-type rainfall simulator consists of three main units.

I. A steel cylinder of $0.25 \mathrm{sq}$. m surface, $0.2 \mathrm{~m}$ side height, which can be sunk into the soil and whose purpose is to accurately delimit the experimental surface

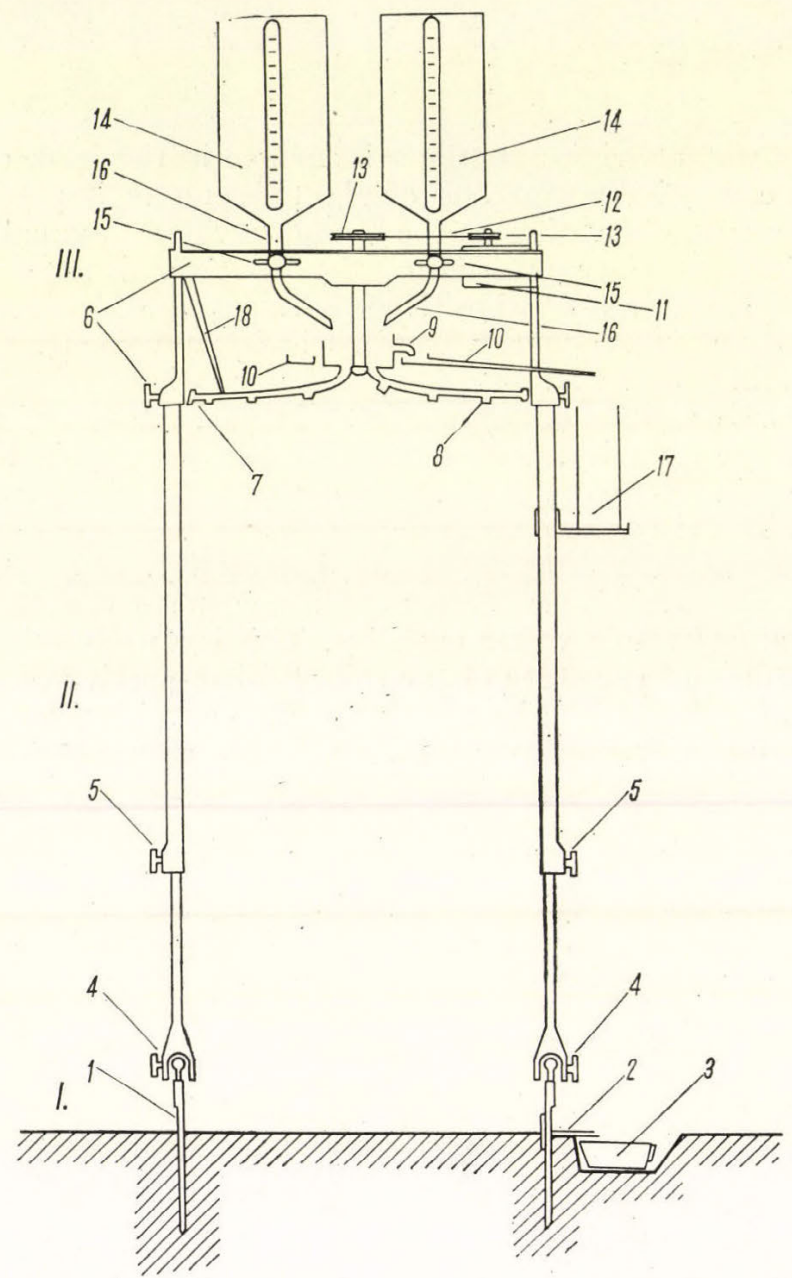

Fig. 1. Scheme of Kazó-type rainfall simulator. I. Steel cylinder of $20 \mathrm{~cm}$ height and 0.25 sq. $m$ area, to be pushed into the soil. 2. Rack, holding the outflow aperture for runoff. 3 . Measuring vessel for the removed soil and runoff. II. Sprinkler head. 4. Ball- and socket joint. 5. Telescoping racks. III. Sprinkler head. 6. Frame with fixing screws. 7. Sprinkler head composed of 12 tubes. 8. Nozzles for the production of uniform drops. 9. Level vessel with overflow. 10. Channel for overflow water. 11. Driving motor. 12. Drive belt. 13. Gear for slowing-down rotation. 14. Water tube. 15. Stop-cocks. 16. Water inlet tube. 17. Collector for overflow water. 18. Striker 
and to prevent lateral infiltration. On the side of the frame into a drainage vessel there is an outflow aperture serving to drain the excess, non-infiltrating water which accumulates during the course of the experiment. The outflow aperture should be flush with the soil (Figs. 1, 2).

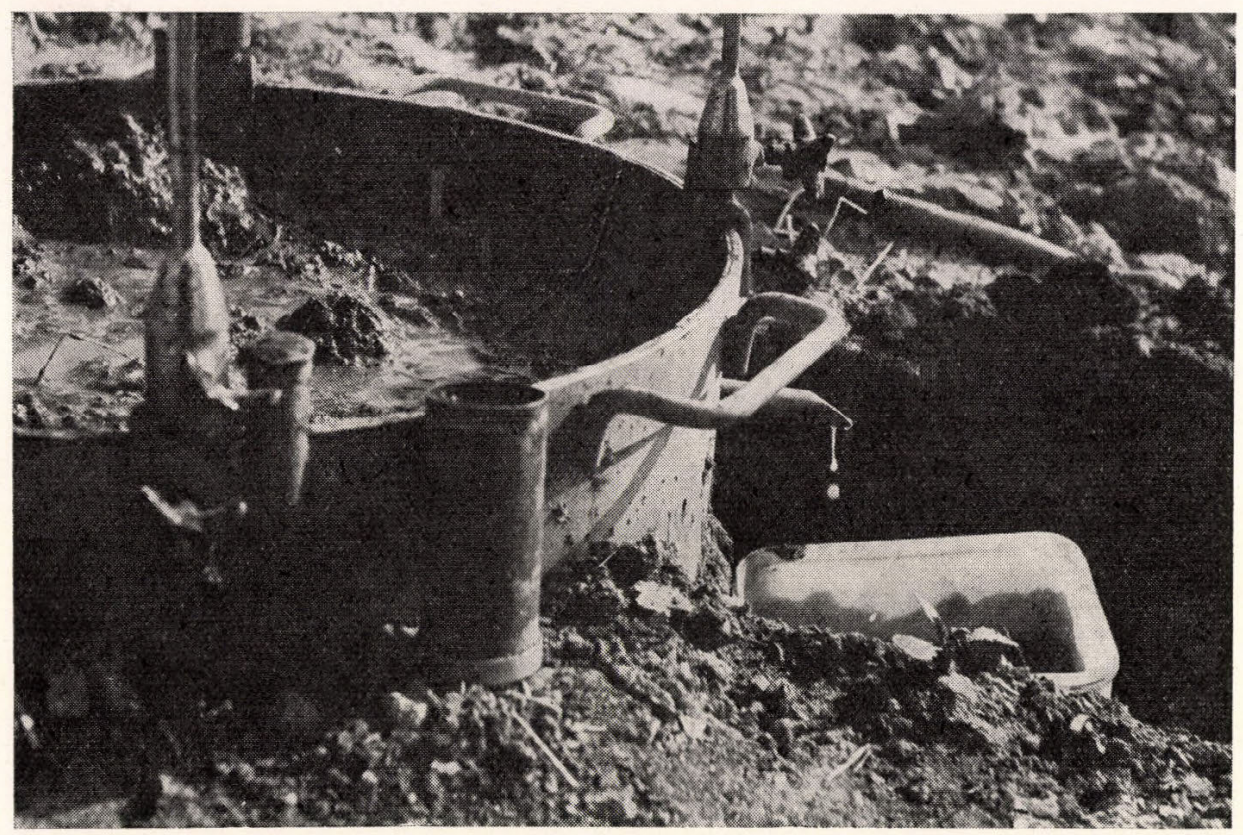

Fig. 2. Steel frame with drainage channel. Photo by L. Lőrinczy

II. A system of telescopic legs is mounted on the frame, which are provided with ball joints for mobility and which serve to keep the sprinkler head precisely one metre above the ground, in the horizontal plane when the ground is sloping. An accessory to this unit is a hood made of plastic sheeting to permit measurement in windy weather.

III. A rotary sprinkler head of 12 radially arranged lengths of pipe is mounted on the above-described legs and rotated at 10 to $14 \mathrm{rpm}$ by a battery-fed electric-motor. Each pipe carries a number of nozzles of $0.3 \mathrm{~mm}$ dia., arranged logarithmically along its length in order to keep raindrop frequency constant as far as possible over the whole experimental area. The sprinkler head is provided with a pair of pulsators which tap upon the radial pipes on opposite sides to promote the formation of equal-sized drops at equal rates. Water pressure in the pipes is kept constant by means of a level tank provided with an overflow. The sprinkler head is fed by two five-litre gravity tanks mounted above it.

The device produces artificial rain consisting of drops of a constant $3 \mathrm{~mm}$ diameter. Constant drop size is assured by the special form of the nozzle bores and by the constant feed rate brought about by the pulsators (Fig. 3). 
The experiment (Fig. 4) has to be performed on any slope up to and beyond 40 per cent in order to characterize numerically the water intake and runoff properties of all within one and the same soil class. Apart from rare exceptions, one does not encounter within a reasonably small space all the possible

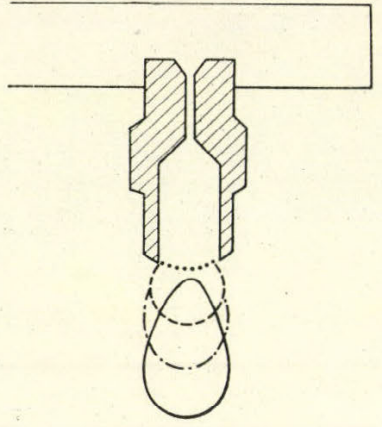

Fig. 3. Formation of drops of constant size in the nozzle

slope categories covered by the same class of soil. This is why the field experiment is carried out, if possible, at a horizontal or near-horizontal spot. Experiments on sloping surfaces are carried out on monolithic soil samples of $0 \cdot 25$ sq. $\mathrm{m}$ surface and $20 \mathrm{~cm}$ height, taken into steel cylinder of suitable size. (Fig. 5). For the purpose of experiments on the principle of a single-armed lever had to be constructed which enables the slope angle of the monolith to be varied from zero to $8,15,21,30$, and 40 percent, respectively, without stopping the rain, i.e. even in the state of saturation to the minimum water capacity.

Sprinkling is to be continued in each titled position for 30 minutes at least, or until runoff becomes constant.

The experiment is carried out as follows: first the sprinkler is mounted at a height of one metre above the steel ring embedded in the soil, and filled with water. The electric motorland water supply are then started. Instantaneously with the emergence of the first drops from the sprinkler head, a stopwatch is started and the events are recorded chronologically. One records the instant when the water is totally and uniformly absorbed by the soil, which is marked by the appearance of a reflecting water film or of small puddles on the soil surface. Unfortunately, the determination of this point by eye is highly subjective, and a more precise procedure would be to record infiltration on slowmotion film (Kazó 1964).

The appearance of water on the surface and the formation of puddles indicates that water infiltration is in approximate equilibrium with "precipitation"; subsequently, the rate of infiltration decreases until it is less than "precipitation". The excess water, now unable to infiltrate, accumulates in pools of increasing size and starts to runoff as soon as the irregularities of the surface permit.

The next point to be recorded is the appearance of water in the outlet of the steel frame, which is considered as the beginning of runoff. From this 
instant on, the amount of runoff accumulated in the collecting vessel is measured every three minutes, and is continued for at least one hour or until the rate of runoff becomes constant.

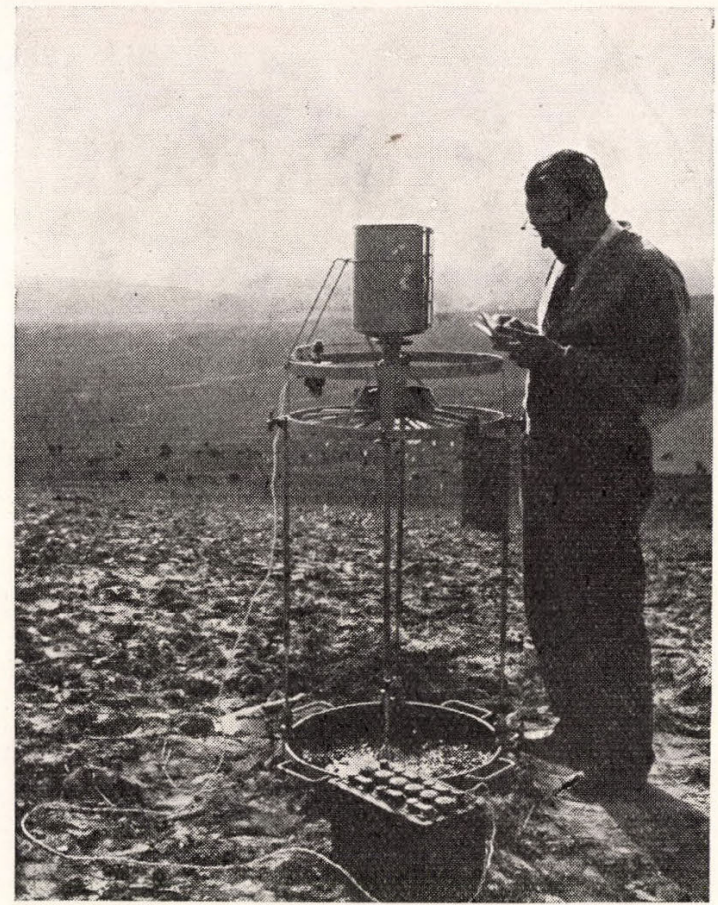

Fig. 4. Fully assembled simulator in operation. Photo by I.. Lőrinczy

After the experiment, undisturbed soil samples have to be taken, with a cylindrical sampler with removable copper lining, of $5 \mathrm{~cm}$ diameter and 10 cm height, of the Klimes-Szmik or similar type (1., 2.), in which the sample can be transported, without being disturbed to the laboratory for further treatment. At least three samples are taken from each depth: 0 to 10 and 10 to $20 \mathrm{~cm}$. Two to five hours after the end of the experiment, similar samples have to be taken from the watered soil, from 0 to $10 \mathrm{~cm}$ depth. These samples serve to determine the original moisture content of the soil, and the various capacity values, i.e. capillary water capacity $\left(\mathrm{Vk}_{\mathrm{cap}}\right)$, total water capacity $\left(\mathrm{Vk}_{\max }\right)$ and minimum or free-air water capacity $\left(\mathrm{Vk}_{\min }\right)$, as well as bulk density and porosity. One should not be satisfied with one experiment in a given area, but should repeat it three or four times depending on the size of the plot.

Experiments continued for several years have proved that from the point of view of the water household of the soil, the uppermost 10 to $11 \mathrm{~cm}$ of the soil complex are of a decisive importance. It is only after the saturation of 
this layer to minimum capacity that the water intake of the soil complex is controlled by the layers farther below.

In evaluating the experimental results, the point one wants to find is when the soil is saturated to minimum capacity. The second point of interest is the

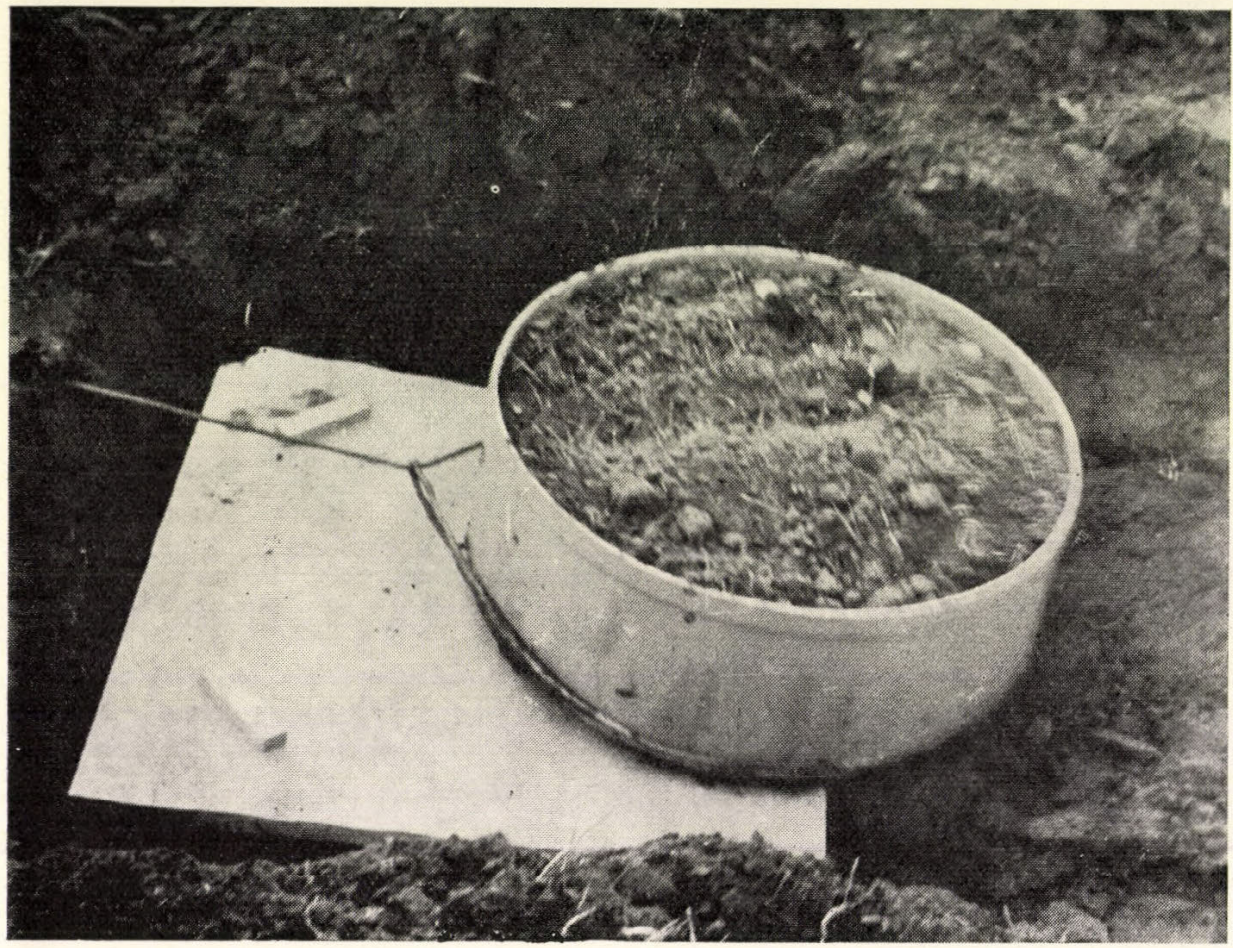

Fig. 5. Taking of a monolith sample for laboratory purposes. Photo by L. Lörinezy

percentage of water the soil is still able to absorb in that state from further rainfall of given intensity. The permeability of the subsurface layers can be expressed in terms of the absorption of the same amount of water that produced saturation to minimum water capacity, and which is applied directly after saturation has been reached. The percentage of this second quantity of water absorbed is a measure of permeability. Series of experiments conducted over several years have proved that when investigating soil erosion, artificial rain applied for one hour at $40 \mathrm{~mm}$ per hour intensity is most significant, and best reveals the intake capacity and permeability features of the soil. For studies into irrigation in plain regions, rainfall for 2 hours at $20 \mathrm{~mm}$ per hour is most expedient.

Figure 6 shows that precipitation at $40 \mathrm{~mm}$ per hour can, in the case of a brown forest soil developed over loess, produce in the relatively short time of two hours saturation to minimum water capacity plus once again the dose 
of water necessary to produce that saturation, more or less independently of the original moisture content of the soil.

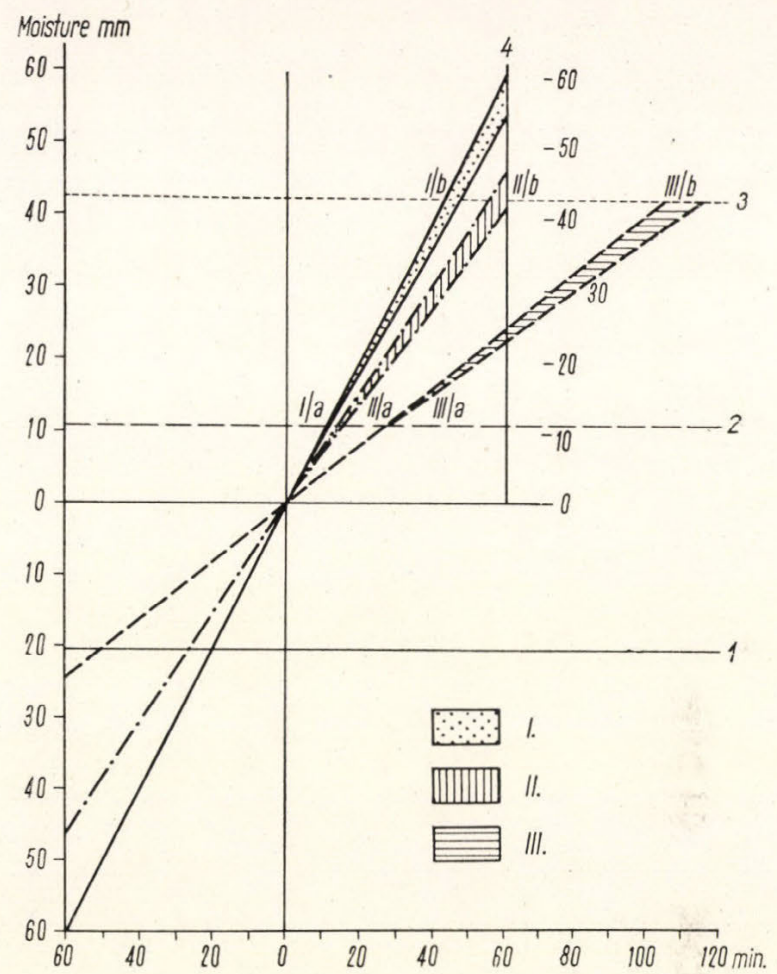

Fig. 6. Water intake capacity and runoff of a brown forest soil over loess (rye stubble field at Zalaapáti, Western Transdanubia) for equal initial mioisture content and various rates of precipitation. Water content of soil vs. time. Precipitation rates: $I=60 \mathrm{~mm}$ ner hour, $\mathrm{II}=46 \mathrm{~mm}$ per hour, III $=24 \mathrm{~mm}$ per hour. 1 - initial moisture content, 2 - saturation to minimum water capacity, 3 - dose of water equal to the one that produced saturation to minimum water capacity, 4 - precipitation rate in $\mathrm{mm}$ per hour. Water intake in percent: $\mathrm{I} / \mathrm{a}=94 \cdot 00 ; \mathrm{II} / \mathrm{a}=89 \cdot 61 ; \mathrm{III} / \mathrm{a}=100 \cdot 00 ; \mathrm{I} / \mathrm{b}=89 \cdot 33 \mathrm{II} / \mathrm{b}=89 \cdot 61 ; \mathrm{III} / \mathrm{b}=90 \cdot 16$. Runoff in percent; I/a $=6 \cdot 00 ; \mathrm{II} / \mathrm{a}=10 \cdot 38 ; \mathrm{III} / \mathrm{a}=0 \cdot 00 ; \mathrm{I} / \mathrm{b}=10 \cdot 66 ; \mathrm{II} / \mathrm{b}=10 \cdot 38$; $\mathrm{III} / \mathrm{b}=9 \cdot 83$.

Experiments performed thus far have covered the following Hungarian soil types: the brown forest soil, the humus carbonate, the chernozem-brown forest soil, the chernozem, and the sandy and eroded skeletal soils. As a result of this work, four soil classes based on water intake capacity, and three classes based on permeability have been established.

I. A soil is of high water intake capacity if after saturation to minimum water capacity it can absorb 100 per cent of the water sprinkled on it at the given rate of precipitation.

II. A soil is of fair water intake capacity if under the above-indicated circumstances it can absorb 80 to 99 per cent of the water sprinkled on it. 

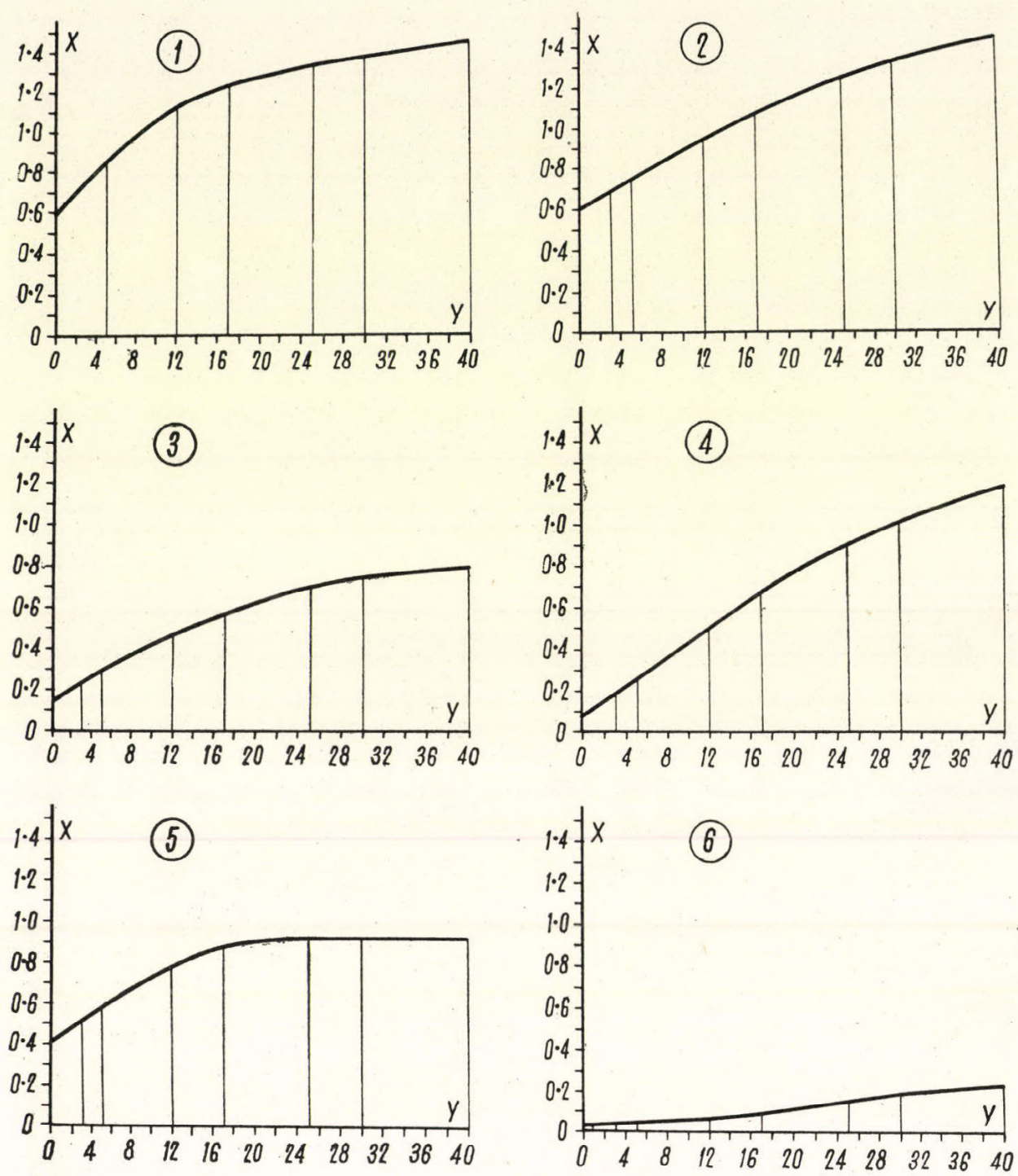

Fig. 7. Runoff diagrams of various soil types. Runoff in $\mathrm{mm}$ from $1 \mathrm{sq} . \mathrm{m}$ of surface vs. slope angle in percent. 1 - brown forest soil, 2 - brown forest soil, 3 - rust-brown forest soil, 4 - brown forest soil with clay illuviation, 5 - meadow soil, 6 - humus slopewash deposit with rock debris.

III. A soil is of medium water intake capacity if, under the above-indieated circumstances, it can absorb 40 to 79 per cent of water sprinkled on it.

IV. A soil is of low water intake capacity if under the above-indicated circumstances it can absorb no more than 39 per cent of the water sprinkled on it. 

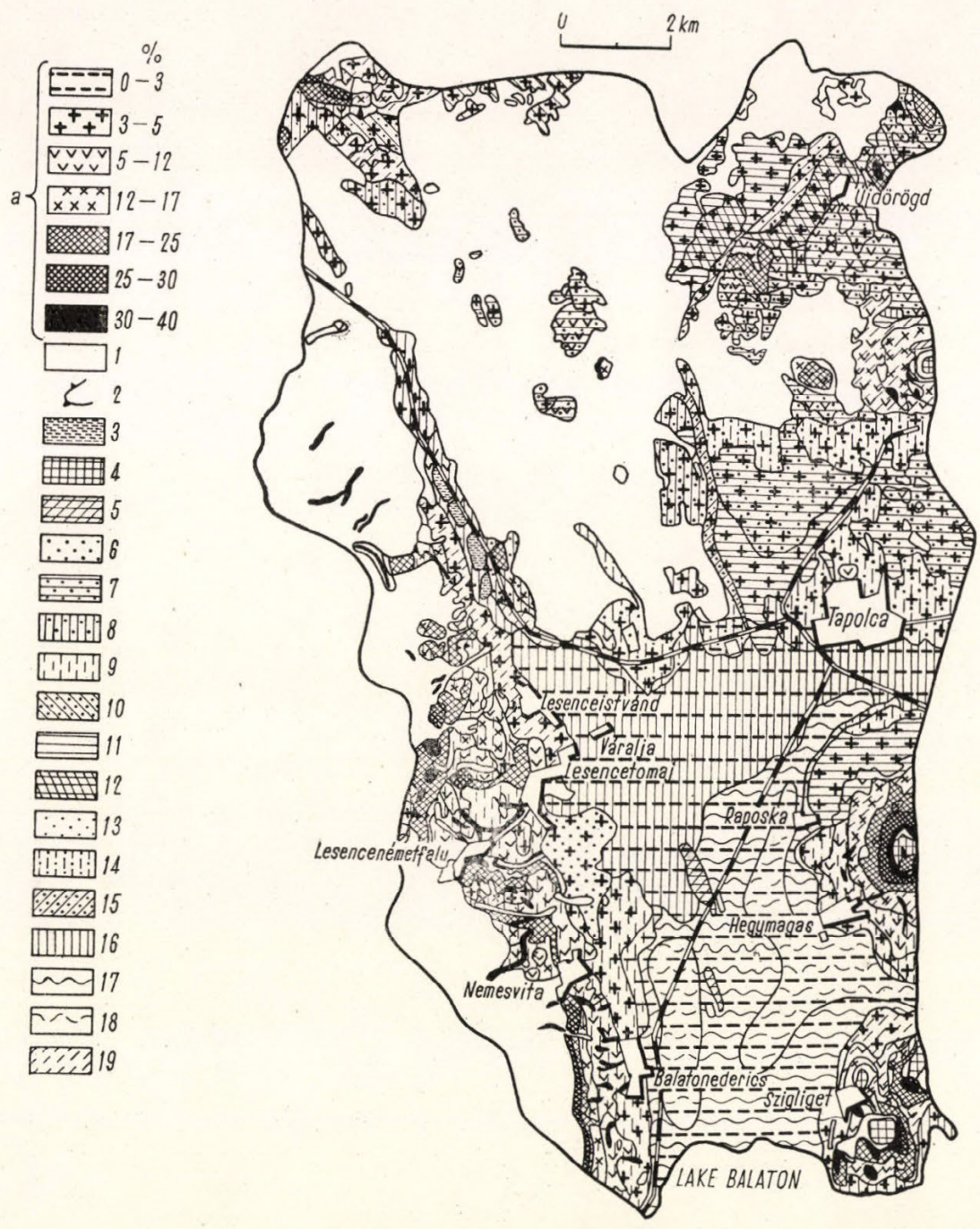

Fig. 8. Runoff map of the western part of the Tapolca Basin, Western Transdanubia, designed by B. Kazó. a - slope categories in terms of slope percents. 1 - forest, 2 - limits of soil types and slope categories, 3 - lake, 4 - basalt scree and skeletal soil, 5 - gravelly skeletal soil, 6 - humus carbonate soil, 7 - rendzina, 8 - brown forest soil with clay illuviation, 9 - brown forest soil, 10 - brown forest soil influenced by rock, 11 - rust-brown forest soil, 13 - brown forest soil with alternating thin layers of clay substance, $14-$ brown forest soil with residual carbonate, 15 - meadow scil, 16 - Marshy meadow soil, 17 - mucky marshy soil, 18 - marsh peat soil, 19 - slope deposit rock debris soil 


\section{Table I.}

Water intake and runoff parameters of the areas shown and numbered in Fig. 9, for a precipitation rate of $40 \mathrm{~mm}$ per hour

\begin{tabular}{|c|c|c|c|c|c|}
\hline Group & Serial & \multirow{2}{*}{$\begin{array}{l}\text { A r e a } \\
\text { sq. m }\end{array}$} & Precipitation & Water intake & \multirow[b]{2}{*}{ Runoff } \\
\hline \multicolumn{2}{|c|}{$\begin{array}{c}\text { number } \\
\text { on the map }\end{array}$} & & \multicolumn{2}{|c|}{$\mathrm{m}^{2} \cdot \mathrm{mm} / 3 \mathrm{~min}$} & \\
\hline 1 & 2 & 3 & 4 & 5 & 6 \\
\hline I. & 1. & 480,000 & 960,000 & 600,000 & 360,000 \\
\hline \multirow[t]{13}{*}{ II. } & 2. & 680,000 & $1,360,000$ & 768,000 & 591,000 \\
\hline & 3. & 15,000 & 30,000 & 13,050 & 16,950 \\
\hline & 4. & 10,000 & 20,000 & 7,600 & 12,400 \\
\hline & 5. & 10,000 & 20,000 & 7,600 & 12,400 \\
\hline & 7. & 878,000 & $1,756,000$ & 772,900 & 983,100 \\
\hline & 8. & 22,000 & 44,000 & 16,200 & 27,800 \\
\hline & 9. & 9,000 & 18,000 & 7,830 & 10,170 \\
\hline & 10. & 10,000 & 20,000 & 7,600 & 12,400 \\
\hline & 11. & 4,000 & 8,000 & 3,040 & 4,960 \\
\hline & 12. & 110,000 & 220,000 & 124,300 & 95,700 \\
\hline & 13. & 228,000 & 456,000 & 198,360 & 257,640 \\
\hline & 14. & 40,000 & 80,000 & 34,800 & 45,200 \\
\hline & 15. & 35,000 & 70,000 & 39,550 & 30,450 \\
\hline \multirow[t]{30}{*}{ III. } & & $2,051,000$ & $4,102,000$ & $2,000,830$ & $2,100,770$ \\
\hline & 6. & 12,000 & 24,000 & 9,120 & 14,880 \\
\hline & 16. & 59,000 & 118,000 & 44,840 & 73,160 \\
\hline & 17. & 4,000 & 8,000 & 2,680 & 5,320 \\
\hline & 18. & 9,000 & 18,000 & 6,100 & 11,920 \\
\hline & 19. & 58,000 & 116,000 & 50,460 & 65,540 \\
\hline & 20 . & 12,000 & 24,000 & 6,720 & 17,280 \\
\hline & 21. & 3,000 & 6,000 & 2,100 & 3,990 \\
\hline & 22 . & 4,000 & 8,000 & 2,560 & 5,440 \\
\hline & 23. & 26,000 & 52,000 & 17,420 & 34,580 \\
\hline & 24. & 120,000 & 240,000 & 91,200 & 148,800 \\
\hline & 25. & 16,000 & 32,000 & 10,720 & 21,280 \\
\hline & 26. & 5,000 & 10,000 & 2,800 & 7,200 \\
\hline & 27. & 40,000 & 80,000 & 25,600 & 54,400 \\
\hline & 28. & 8,000 & 16,000 & 6,080 & 9,920 \\
\hline & 29. & 2,000 & 4,000 & 1,120 & 2,280 \\
\hline & 30. & 14,000 & 28,000 & 10,640 & 17,360 \\
\hline & 31. & 44,000 & 88,000 & 29,480 & 58,520 \\
\hline & 32. & 25,000 & 50,000 & 21,750 & 28,250 \\
\hline & 33. & 4,000 & 8,000 & 2,680 & 5,320 \\
\hline & 34. & 13,000 & 26,000 & 7,280 & 18,720 \\
\hline & 35. & 5,000 & 10,000 & 3,200 & 6,800 \\
\hline & 36. & 3,000 & 6,000 & 2,010 & 3,990 \\
\hline & 37. & 28,000 & 56,000 & 24,360 & 31,640 \\
\hline & 38. & 42,000 & 84,000 & 31,920 & 52,080 \\
\hline & 39. & 3,000 & 6,000 & 1,920 & 4,080 \\
\hline & 40. & 4,000 & 8,000 & 2,240 & 5,760 \\
\hline & 41. & 6,000 & 12,000 & 3,840 & 8,160 \\
\hline & 42. & 22,000 & 44,000 & 16,720 & 27,280 \\
\hline & 43. & 25,000 & 50,000 & 21,750 & 28,250 \\
\hline
\end{tabular}




\begin{tabular}{|c|c|c|c|c|c|}
\hline Group & Serial & \multirow{2}{*}{$\begin{array}{l}\text { A r e a } \\
\text { sq. m }\end{array}$} & Precipitation & Water intake & \multirow[b]{2}{*}{ Runoff } \\
\hline \multicolumn{2}{|c|}{$\begin{array}{c}\text { number } \\
\text { on the map }\end{array}$} & & \multicolumn{2}{|c|}{$\mathrm{m}^{2} \cdot \mathrm{mm} / 3 \mathrm{~min}$} & \\
\hline 1 & 2 & 3 & 4 & 5 & 6 \\
\hline & $\begin{array}{l}44 . \\
45 . \\
46 . \\
47 . \\
48 . \\
49 . \\
50 . \\
51 . \\
52 . \\
53 . \\
54 .\end{array}$ & $\begin{array}{r}47,000 \\
26,000 \\
28,000 \\
3,000 \\
5,000 \\
10,000 \\
5,000 \\
5,000 \\
25,000 \\
73,000 \\
30,000\end{array}$ & $\begin{array}{r}94,000 \\
52,000 \\
56,000 \\
6,000 \\
10,000 \\
20,000 \\
10,000 \\
10,000 \\
50,000 \\
146,000 \\
60,000\end{array}$ & $\begin{array}{r}31,490 \\
16,640 \\
15,680 \\
1,920 \\
3,200 \\
6,700 \\
3,350 \\
3,200 \\
21,250 \\
55,480 \\
19,200\end{array}$ & $\begin{array}{r}62,510 \\
35,360 \\
40,320 \\
4,080 \\
6,800 \\
13,300 \\
6,650 \\
6,800 \\
28,250 \\
90,520 \\
40,800\end{array}$ \\
\hline & & 873,000 & $1,746,000$ & 637,920 & $1,108,290$ \\
\hline
\end{tabular}

1. A soil is of high permeability if after saturation to minimum water capacity it can transfer 90 to 100 per cent of a second quantity of water, equal to that which produced the said saturation, and sprinkled on it at the given rate of precipitation, to the deeper soil layers.

2. A soil is of medium permeability if under the above-indicated conditions it can transfer 60 to 90 per cent of te second quantity of water to the deeper soil layers.

3. A soil is of los permeability if under the above-indicated conditions it can transfer less than 60 per cent to the deeper soil layers.

As stated above, the excess water not absorbed by the soil collects on the surface and runs off as soon as the configuration of the surface permits. Soils can be classified into four groups according to the quantity of runoff and into three subgroups according to changes in the rate of runoff.

A. A soil is of low, runoff type if in the state of saturation to minimum water capacity it allows less than 10 per cent of the water sprinkled on it at the given rate to run off.

B. A soil is of medium runoff type if under the above indicated circumstances it allows 10 to 20 per cent of the water to run off.

C. A soil is of high runoff type if under the indicated circumstances it allows between 20 and 60 per cent of the water to run off.

D. A soil is of dangerously high runoff type if under the indicated circumstances it allows more than 60 per cent of the water to run off.

(a) If the runoff at the point of saturation to minimum water capacity, $Q_{1}$, is the same as the runoff $Q_{2}$ after a second addition of water, equal to the one that produced the said saturation, sprinkled on at the given rate of precipitation, i.e. $\mathrm{Q}_{1}=\mathrm{Q}_{2}$, then the soil is said to have a constant rate of runoff.

(b) If under the above-indicated conditions $Q_{2}$ exceeds $Q_{1}$ by from 5 to 20 per cent, then the soil is said to have an increasing rate of runoff. 
(c) If under the above-iudicated conditions $\mathrm{Q}_{2}$ exceeds $\mathrm{Q}_{1}$ by more than 20 per cent, then the soil is said to have a suddenly increasing rate of runoff.

From the plots of experiments on sloping soil samples one may compute runoff for any slope angle. Hence, the above method permits one to plot on maps comparable values of water intake capacity (to characterize water household) and of runoff (to characterize liability to erosion).

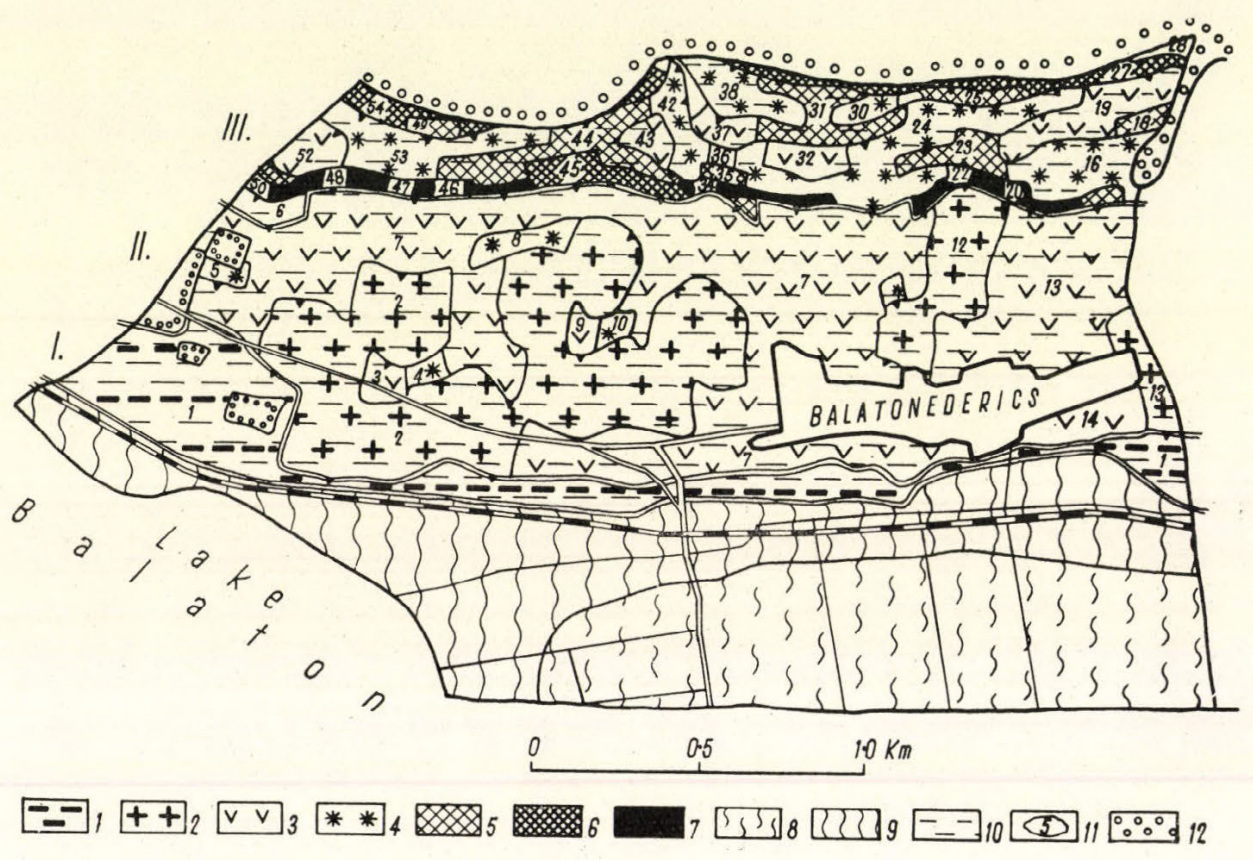

Fig. 9. Detailed runoff map of the southwestern part of the Tapolca Basin. 1-7. Dip percentages: $1=0-3 ; 2=3-5 ; 3=5-12 ; 4=12-17 ; 5=17-25 ; 6=25-30$; $7=30-40 ; 8-10$. Soil varieties: $8=$ Peat soil. $9=$ Swamp soil. $10=$ Brown earth. 11 = Slope categories (see Fig. 8.). 12 = Forest

Figure 7 shows the plots of experiments for some soil types, which permits one to compute directly the water intake and runoff characteristic of any angle of slope. Runoff is given in millimetres of water delivered over 3 minutes by a surface of $1 \mathrm{sq}$. $\mathrm{m}$ receiving precipitation at the rate of $40 \mathrm{~mm}$ per hour after saturation to minimum water capacity. The given values are averages over 30 minutes, and were plotted against slope angle. Since all other parameters were kept scrupulously constant, it is safe to say that any changes occurring are attributable to slope angle.

The diagrams refer to the following soil types: two brown forest soils, a rust brown forest soil, a brown forest soil with clay illuviation, a meadow soil and a humus slope deposit, rocky debris soil, all of which were obtained from the drainage area of the western part of the Tapolca Basin in Western 
Transdanubia. On the drainage map of 1 to 25,000 scale, the slope angles were determined by the method of Gy. Lovász (1965): and the expected runoff direction is indicated by spikes. Symbols for slope angle are printed in heavy type over a base of thin-line symbols of the soil type. The water household data of the individual areas are readily computed from the above-mentioned plots on the one hand, and the sizes of the areas of equal slope, on the other. To increase accuracy, we have blown up part of the $1: 25,000$ scale map to 10,000 scale and carried out some actual computations for this area. The water household parameters of the areas outlined and numbered in Fig. 8 are given in Table I for a precipitation rate of $40 \mathrm{~mm}$ per hour.

The values in Table I were obtained as follows. First, the portions belonging to the same slope category within the given drainage area were delimited and numbered. The areas thus obtained were planimetered and using the experimental results, the runoff from the individual areas was computed. This data served as a basis for computing the total runoff on the one hand, and, taking into consideration runoff directions also, for estimating liability of erosion, on the other.

The map of runoff characteristics serves as a basis for determining the size of drains, tanks, culverts, etc. to be constructed, in the framework of a technical erosion prevention system and the most favourable plot size and cultivation types for preventing soil erosion. The water intake capacity parameter serves to compute the water household of the soil, irrigation parameters and the likelihood of formation of stagnant pools.

\section{REFERENCES}

Ballenegger, R. and Di Gléria, J. (1962): Talaj-és trágyasizsgálati módszerkönyo (Soil and manure testing manual). Budapest: Mezőgazdasági Kiadó.

Di Gléria, J., Klimes-Szmik, A. and Dvoracsek, M. (1957): Talajfizika és talajkolloidika (Soil physics and soil colloid chemistry). Budapest: Ákadémiai Kiadó.

Kazó, B. and Klimes-Szmik, A. (1962): A Method of Artificial Sprliinkng for the Investigation of the Process of Erosion. International Association of Scientific Hydrology, Publ. No. 59, pp. 52-61, (Symp. Bari)

Kazó, B. (1964): Untersuchung der zum Oberflächenabfluss führenden Prozesse mittels Filmaufnahmen. Agrokémia és Talajtan, 13, Suppl., pp 3-10.

Kazó, B. (1966): The determination of the water regime properties of soils with an Artificial Rainfall Simulator. Agrokémia és Talajtan, 15, pp 239-252.

Lovász, Gy. (1965): A reliefenergia új ábrázolása (A new representation of relief energy). Földrajzi Értesítô 14, 1, pp 131-146. 



\section{THE CLARIFICATION OF SOME TERMS USED IN GEOMORPHOLOGY}

by

M. PÉ C S I

\section{INTERPRETATION AND NOMENCLATURE OF THE MORE IMPORTANT CONCEPTS OF GEOMORPHOLOGY}

The frequently used terms concerning exogenetic processes in geology and geomorphology tend to acquire, almost from the moment of their introduction varying interpretations by different authors (Baulig 1956, Davis 1955, Nikolaev 1958, Schaeffer 1959, Stamp 1962).

Differences varying in degree from fine nuances to quite fundamental ones in the usage of the most basic terms are becoming ever more frequent in the almost frustratingly copious literature of our branch of science. Although there are quite a number of technical dictionaries to provide help (for the more important ones, see the annexed list of references), even the definitions given in these may be at substantial variance. The differences not only occur between language areas but also between schools of thought and may further vary in time. Moreover, one and the same term may carry slightly different shades of meaning even in the different works of the same author.

Recent interest in this problem is based on the rapid increase in the last few years of the number of international symposia. Furthermore, the Geomorphological Commission of the International Geographical Union has resolved to work out a unified set of geomorphological symbols. No common standpoint has so far been arrived at, however, in the interpretation of even the most commonly used terms. Consequently, translated texts have a tendency of not correctly reflecting the original meaning of the author.

The present paper is to outline the fundamental and more subtle differences in the interpretation of the most important geomorphological terms. Although any addition to the number of terms, large enough as it is, was far from being the author's intention, the introduction of some new ones appeared indispensable to help disentangle the present and rather complicated situation.

\section{1/1. DENUDATION}

Almost since it was first coined by Lyell, this term was employed in both a broad and narrow sense.

1/1.1. According to the dictionaries and textbooks, the broader meaning of the term includes destruction by any and all exogenetic forces. More specifically, it includes weathering, comminution, transport and all manner of wear during transport. In this sense, the antonym of denudation is sedimentation (deposition, accumulation) (Bulla 1954, Leopold-Wolman-Miller 1964, Moore 1962, Scheidegger, 1961, Grigoriev 1960, Panov 1966).

$1 / 1.2$. There are several interpretations of the meaning of the term in the narrow sense, but most of them can be incorporated under two headings: 
1/1.2.1. According to one: interpretation, denudation includes weathering and comminution as well as mass wasting. As a result, the bedrock is exposed, denuded, and stripped. An even narrower interpretation reduces the term to mean the action of slopewash and its results.

1/1.2.2. According to another interpretation, denudation is the truncation of mountain and foreland relief, their general wearing away, and the formation of so-called surfaces of denudation. In this sense, the term is synonymous with planation.

(The above comprehensive, generalized interpretation of the term denudation is not used consistently by different authors and different language groups, quite apart from having also undergone changes in time.) The assertion encountered in some dictionaries that either the narrower or broader interpretation of the term is used consistently within different language area does not stand up to scrutiny. It is perhaps in the French literature that the term denudation is employed almost invariably in the narrower sense if at all. In the English language and Russian literature, on the other hand, it occurs in both the narrow and broad sense (Nikolaev 1958, Grigoriev 1960-66, Panov 1966).

According to Moore (1962), denudation is the wearing away of the relief by various natural agencies. In his view denudation and deposition are the two most general processes acting upon the surface of the Earth and participating in the modelling of its relief. The "Dictionary of Geological Terms" (1962) gives a double meaning to the term: (1) a laying bare, the process of washing away of the covering strata, (2) that process which, if it would act long enough, would reduce all inequalites of the Earth's surface to a uniform base level.

According to L. B. Leopold, M. G. Wolman and J. P. Miller (1964) the term includes three sub-processes: (1) weathering and comminution of rocks, (2) mass wasting, (3) transportation and deposition. In this more comprehensive interpretation, the term would also include sedimentation, in contrast to Moore.

It has been stated by several authors that denudation is employed in AngloSaxon literature synonymously with erosion. This generalization is not quite correct, because weathering is not included, except by a very few authors, in the term erosion. Holmes (1944), Scheidegger $(1961)^{1}$ and others have unambiguously stated the scope of denudation to be broader than that of erosion.

Denudation is employed by Davis as the comprehensive term covering all processes acting particularly in the juvenile and early mature stages of the cycle of erosion; this usage is in keeping with the original meaning of the term, i.e. they strip the bedrock, laying it bare. According to Davis, denudation is succeeded in the later stages of the cycle of erosion by degradation (see later). Hence, in the writings of Davis and his followers, denudation is the

\footnotetext{
1 "The material moving over a slope by the above-mentioned process helps further wearing down the slope. This wearing-down process has been termed corrasion. It occurs without the intermediary of any further medium. In contrast to corrasion one has erosion. This process is caused by the intermediary of some moving medium such as wind, water or ice. It also causes the wearing down of the slope. The combined effect of the above agents is termed 'denudation'." (A. E. Scheidegger: Theoretical Geomorphology, p. 3.)
} 
process dominating the initial and mature stage of the evolution of relief. In other words, denudation is restricted to the higher-altitude regions of mountains, where the relief is in the juvenile or mature stage. Strahler (1963) also employs the term denudation in the broad sense. However, he applies the term erosion to the totality of exogenetic processes contrasting the processes and forms of erosion with those of deposition.

Stamp (1962) provides a detailed discussion of the various uses of the term in the English language literature: in his opinion, "The term is commonly used widely and loosely" although denudation is sometimes substituted by terms such as degradation or destruction.

In early Russian literature, as presented in "Nikolaev's comprehensive review (1958) the term denudation is employed both in the broad and in the narrow sense. The same holds also in the recent literature (Panov 1966, A. A. Grigoriev 1960-66). Under the heading of denudation in the narrow sense, Panov discusses destruction by gravity, i.e. mass wasting.

In the Polish literature (M. Klimaszewski 1963) the term denudation occurs in two narrow senses and one broad sense: the two former include mass wasting due to gravity on the one hand and the processes resulting in denudation valleys,--dry, broad, flat valley forms,- on the other; in the broad sense, the term is employed in the same way as planation, for the degradation of interfluvial ridges in mountainous areas. Of course, the latter process is due to a combination of exogenetic forces rather than to mass wasting alone.

W. Penck (1924) also employs the term in a narrow and somewhat specialized sense, to mean the comminution of rocks and the uncovering of the bedrock by the removal of the loose products of weathering. Denudation as understood by Penck will in no case result in slope steepening, as will erosion. According to Penck denudation is dominant in the upper sections of slopes, followed downslope, first, by corrasion and then by erosion which both act together with denudation in the zones of transition, but finally, in the lower slope sections, erosion becomes dominant. This is an interpretation of denudation which restricts the process to certain altitude zones and considers it to result in a smoothing of the relief, in contrast to corrasion and erosion which produce linear, incised furrows. According to him, in the erosive zones the influence of denudation is restricted. However, although valley incision results in the dissection of the area of denudation, this does not mean that its sphere of influence is restricted, because the actual slope surface accessible to denudation is thereby increased.

Interpretation of the term denudation is not unequivocal in the German dictionaries either (Neef 1962, Murawski 1963, Schaeffer 1959). The term according to most of these is meant to cover the entire span of the processes of mass wasting. Some state, however, that denudation is sometimes employed synonymously with ablation, destruction and "Abtragung" (Schaeffer). Yet the German literature tends to replace all these terms by the common term "allgemeine Abtragung". Schaeffer, Panzer and others propose to restrict the term to mean superficial degradation, as opposed to erosion which is, according to them, largely linear. While recognizing the inherent equivocality of the terms, they admit that, in the final reckoning, linear erosion, too, results in a general lowering of the relief, i.e. denudation in the broad 
sense. But in all, Schaeffer's attempt at clearly distinguishing denudation from erosion (1959) is something of a failure. ${ }^{2}$

J. Büdel (1944) interprets denudation in the broad sense, as the totality of the results of exogenetic forces (l.c. p. 485), and is synonymous with the term "Abtragung". He distinguishes the creep of loose detrital cover and the degradational activity of the same by the term "flächenhafte Abtragung". C. Troll's term of "subnivale Denudation" also has a broad meaning.

According to Machatschek (1952), denudation is either employed in the literal sense, meaning the removal of the loose soil and subsoil from the compacted bedrock, or in a general sense, synonymously with "Abtragung". W. Panzer (1965) represents the opposite view and interprets denudation to mean the weathering and comminution of the bedrock plus the movement of the detritus, which in their totality result in the laying bare of the bedrock.

It emerges from the above citations that the duality of the term denudation is reflected also in German literature (Murawski 1963).

The usage of the term is not uniform in Hungarian geomorphological literature, either. According to B. Bulla (1954), "in the interpretation of most authors, denudation means ... the sculpture of the relief by exogenetic forces in general, and it is in this sense that they speak of normal (fluvial), glacial and desert denudation. Here denudation is used synonymously with destruction, the wearing-down process (p. 95). According to some other authors, also cited by Bulla, denudation includes not only desctruction but comminution and weathering as well. Since the several interpretations of the term denudation may result in numerous misunderstandings and errors, B. Bulla is of the opinion that it is best avoided, or used, if absolutely necessary, as a synonym of the wearing-down process. Elsewhere (p. 11.) he speaks of forms of denudation as opposed to forms of accumulation. In his general geomorphological views, as reflected in his papers, Bulla is, however, much more explicit, where by denudation he means the totality of destruction by exogenous forces, which is also accepted in Hungarian geological literature (Vadász 1953, Vendl 1951, 1952).

Before stating what the present author deems the most expedient use of the term denudation, it seems to be necessary to point out that in terms like the base of denudation, upper or losver levels (niveaux) of denudation, absolute or local bases of denudation, the usage is much more uniform in the literature. This is even more true of the terms rate of denudation etc. The latter is generally considered to mean the measure of the lowering of the relief during a given span of time under the influence of all exogenetic agencies.

It is in a similar sense that the terms upper and lower level of denudation are employed. On the other hand, the terms absolute and local base of erosion

\footnotetext{
2 “Von den 'trockenen' zu diesen 'feuchten' Massenbewegungen bestehen jedoch eine Reihe unmerklicher Übergänge, ebenso läßt sich kein Schnitt zwischen der Tätigkeit des spülenden und der des fließenden Wassers ziehen. So sind Denudation und Erosion eng miteinander verknüpft. Die flächenhafte Denudation ist vielfach nur ein Produkt kleinster Erosionsvorgänge. Umgekehrt kann die an sich linienhaft arbeitende Erosion, etwa bei Vorherrschen der fluviatilen Seitenerosion oder bei Glazialerosion, so in die Breite wirken, daß es zu flächenhafter Abtragung, also zu Denudation kommt." ("Allgemeine Geographie"-Das Fischer Lexikon. 1959. p. 25.)
} 
are widely used for fluvial activity. A river is incapable of eroding at a level deeper than the base of erosion and neither can it transport any waste (W. Penck). For a river, the absolute base-level of erosion is sea level. Any point on the river bed is the local base-level of erosion for all points situated upstream from the point in question. According to W. Penck, similar base-levels can be ascribed not only to fluvial activity but to all the other exogenetic processes. For moving ice, it is the level at which ice melts or at sea level where the buoyancy of ice lifts it off the bedrock. The term base of denudation is used by Penck exclusively for mass-wasting procésses. In his interpretation, the base-level of denudation is where movements involving mass wasting come to an end. For downslope mass wasting, the general base of denudation is the river bed, i.e. the point on the longitudinal river profile at which mass wasting is checked. However, mass wasting occurs on the sea-shore as well as in river valleys. Hence, in the present writer's opinion, the Penckian distinction of a general base-level of denudation is superfluous, as it is essentially the same as his concept of the local base-level or erosion, referring to any point on the longitudinal profile of the watercourse.

In Penck's opinion the local base-levels of denudation are functionally independent of, or indeed, completely different from the base-levels of the river. Bases of denudation may develop at different levels upslope, as functions of the resistance of the bedrock and of the geological structure. According to Penck, the various base-levels of denudation find expression in the breaks of slope profile. Hence, in this sense, the Penckian base of denudation is restricted to the processes of mass wasting. Undoubtedly, the base-levels of the various processes of exogenous origin (fluvial, eolian, glacial processes, comminution, weathering, mass movement downslope) may all be different, but there is still the need of a common term for all these base-levels. None of the numerous workers using the terms, upper limit of denudation or rate of denudation would restrict these terms to comminution, weathering and mass transport by gravity.

In most of the geomorphological literature, the concept of denudation is meant to cover the broader scale of ideas outlined above (cf. Stamp, 1962), including the wearing-down of the relief by all exogenous agents, in the sense of the "allgemeine Abtragung". As an antonym, sedimentation with the synonyms deposition and accumulation may be mentioned.

In keeping with what has already been stated, the present writer feels that the term denudation is used most expediently in the broad sense, to include the various processes of comminution and weathering, destruction (wearingdown) by water (slopewash, linear-fluvial erosion, destruction by the sea), wear and transport by wind and ice, and mass wasting due to gravity on the slopes.

The term denudation in the narrow sense, where it covers comminution, weathering and mass wasting only, should, in the present writer's opinion, and in order to avoid further misunderstandings, be replaced by the term derasion (Pécsi 1964, 1966).

For the other, narrow meaning of denudation, which includes the lowering of the relief, i.e. of the interfluvial ridges of the mountains, by a number of interacting processes, the term deplanation is suggested, because this pro- 
cess results in the diminution of slope angles and in the formation of truncated interfluvial surfaces or planation flats (levels of denudation in the earlier nomenclature).

The smoothing of the relief by deplanation is opposed to that by deposition or accumulation of sediments, for which the term applanation is proposed. Of course, deplanation may be subdivided, either according to climatic zones or according to the exogenous agent involved, into several classes such as cryoplanation, peneplanation, pediplanation, pedimentation (thalassoplanation, etc.).

\section{1/2. DEGRADATION-AGGRADATION}

According to Thornbury (1954) (citing Chamberlin and Salisbury 1904), the sum total of the activities of exogenetic agencies, which tend to reduce the relief to an even surface, is termed gradation, comparing degradation for processes wearing down the landscape (destruction) and aggradation for processes building up the land surface. Logically, this classification is correct, but the use of the terms degradation and aggradation in the broad sense just outlined is far from general: on the contrary, the terms are usually given different, and mostly narrower interpretations.

1/2.1. Degradation is most frequently used in the English language literature, its meaning being more or less synonymous with that of denudation or erosion in the broad sense. According to Davis's (1955) broad interpretation, the principal agent lowering the interfluvial ridges in the early stages of the erosion cycle is degradation, whereas the process of slope smoothing dominant in the late stages of the cycle of erosion is denudation.

Rice (1941) uses the term degradation to mean the general lowering of the terrestrial surface through the processes of erosion, emphasizing that the removal of waste is by fluvial activity. The most general interpretation is that of Thornbury (1954), according to whom degradation is composed of three successive groups of processes: (a) weathering and comminution, (b) transportation, (c) erosion.

In the narrow sense of the term, Davis interprets degradation as the incision of a river bed into its valley bottom. The same interpretation is found in Cotton (1942), L. B. Leopold, M. G. Wolman, J. P. Miller, (1964) and today it is most often used in this narrow sense (Stamp 1962).

The most widely accepted formula seems to be that given by Moore. According to him, degradation means the destruction of land masses, largely by fluvial activity, including the lowering of valley bottoms. However, the term also includes the destructive action of glaciers.

A review of the literature shows that the term degradation is far from being generally used in the broadest sense attributed to it by Thornbury, which includes the destructive action of all exogenetic agencies. Moreover, European usage quite frequently narrows it down considerably, to mean for example soil degradation or permafrost degradation (Dylik 1964).

1/2.2. The general interpretation of the term aggradation in the English language is, the deposition of waste in the sea or on the land. Davis (1955) 
used the term to mean deposition in river valleys beyond large, and it is similarly used by Cotton (1952) and Rice (1941), but with special emphasis placed on the filling-up activity of rivers in the semiarid climatic zones, and also the local formation of aggraded valley plains. It was for this latter process that Wooldridge and Morgan (1937) used the term alluviation.

As is apparent from the above selection, the meanings of the term aggradation are also highly varied. In the narrow sense, the term means deposition in a river bed or on a valley floor. In the broad sense, it means the deposition of waste in basins or areas of general accumulation (Thornbury). In this latter sense, it would be a synonym of sedimentation, accumulation and deposition. This broad interpretation is, however, misleading as the usage of the terms deposition and sedimentation in the literature is much more unequivocally for the processes of deposition or the accumulation of waste transported by the exogenetic agencies. In this respect, Holmes's (1944) classification seems to be most acceptable. According to that author, the processes of deposition - sedimentation-as opposed to those of denudation, include three main groups, (1) mechanical transportation and deposition of waste, (2) transportation and deposition from aqueous solution, with or without the interaction of living organisms (e.g. coralline limestone) by evaporation or by chemical precipitation, (3) the accumulation of organic matter. Aggradation may also be regarded as part of the processes of sedimentation or deposition, and it is so regarded by most recent authors (Leopold, Wolman and Miller 1964, Cotton 1952, Strabler 1963, etc.).

\section{1/3. EROSION}

In its broad sense, this term covers the dissection and carving up of the relief by rivers, wind, snow, glaciers and marine action. An even broader interpretation is made by some authors who add to the above processes weathering, comminution and mass wasting (e.g. Howell 1957, Schieferdecker 1959, G. and H. Termier, 1963), and indeed, also the deposition of waste, (Derruau).

In the narrow sense, erosion is used to mean linear fluvial activity, (fluviatile erosion) as opposed to areal destruction, "denudation" (W. Penck 1924, B. Bulla 1954, I. Schaeffer 1959, W. Panzer 1965, and others). Some dictionaries suggest this broad interpretation occurs largely in the English and French literature, and the narrow one in the German literature (Murawski 1963, Schaeffer 1959, Schieferdecker 1959). Although not unfounded, this distinction is not generally valid, as both interpretations are encountered in the literatures of both language areas.

It is true that in the English and French literature the term erosion is used in so broad a sense as to make it almost or wholly synonymous with the wide interpretation of denudation (Davis and Snyder 1898, Cotton 1952, G. and H. Termier 1963, Derruau 1962, and others). On the other hand, in the opinion of several authors, erosion is only one of a number of denudation processes, or even narrower in meaning (Wooldridge, Morgan 1937, Holmes 1944, Scheidegger 1961, Leopold 1964). 
Thornbury (1954) likewise considers erosion to be part of degradation. According to him, the forces of erosion include the action of river water, of ground and subsurface waters, the currents and wave action of lakes and seas, and the action of wind and glaciers. This interpretation is fairly broad but not synonymous with denudation in its broad sense.

Thornbury also includes under the heading of erosion the processes of removal and transportation of waste, but not of deposition. This interpretation of erosion is most common in the recent books and dictionaries of dynamic geomorphology and geology (Baulig 1956, Derruau 1962, Machatschek 1952, Moore 1962, Neef 1962, Panov 1966, Panzer 1965, and others).

German literature reflects a tendency to restrict the meaning of the term erosion to linearfluvial erosion (Machatschek 1952, Murawski 1963, Panzer 1965, Schaeffer 1959) as opposed to slopewash ("Abspülung") and mass wasting. This restricted interpretation has found its way into the Hungarian literature where it is still current.

One of the effects of erosion is the picking up and removal of grains of waste and of detritus. This hydraulic action of moving water is described by the term fluvioraption (Thornbury 1954). In the case of the wind, the corresponding term is deflation.

The wear and breaking up of the bedrock by the agents of erosion or by its transported waste is called corrasion, abrasion. The mutual wear, comminution and breaking up of waste in the course of transportation is termed attrition. The intensity of every one of these processes depends largely upon the mode of transportation (jumping, rolling, dragging, shoving, transportation in suspension, solution or colloidal form), as well as upon the physical and chemical nature of waste and the nature of the transporting medium.

The mechanical action within a watercourse is summed up by the term fluviatile erosion or, more precisely, fluviatile corrasion (Baulig, Strahler, Thornbury).

Fluviatile erosion-corrasion-exerts a mechanical, wearing and destructive action on the bed and on the banks of a river. As a result, the bed is incised and the banks are undercut by fluvioraption. Incision-vertical erosion, linear erosion or corrasion-may act simultaneously with lateral erosion-lateral corrasion (Thornbury, Strahler, Baulig, Lobeck, Moore, Penck).

In summary, even the broadest interpretation of erosion is narrower than the sum total of all exogenetic processes although it may be meant that way. in an inaccurate use or interpretation of the term. In the present author's opinion, the term erosion is to be most widely and also most expediently reserved for the processes of nature which selectively dissect and destroy the relief being confined to certain trajectories, as opposed to the widespread areal processes of mass wasting and slopewash. The latter are, as proposed in the foregoing chapter, to be discussed under the heading of derasion.

\section{1/4. ABLATION}

This term is encountered much more seldomly than either denudation or erosion. Its interpretation is, however, just as ambiguous being used in the 
international literature in both a broad and a narrow sense. In the former, it means the removal by slopewash of waste produced by weathering and comminution (Baulig 1956, Rice 1941), and is frequently extended to cover removal by mass wasting also (Baulig).

In the narrow sense, the term means the desctruction of glacier surfaces by meltwater and evaporation (Cotton 1944, Bulla 1954). Flint extends the term to the similar destructive processes acting on snow surfaces (1947).

Another narrow interpretation covers the removal of matter from sand surfaces (Kádár, 1954, Schaeffer 1959, etc.). According to Kádár, ablation is deflation in a restricted sense, inasmuch as the transported grains exert eolian corrasion as well.

The above two narrow interpretations are frequently distinguished as eolian ablation on the other hand as glacial ablation. Used in such a way, the terms become clear and unequivocal.

On the other side, ablation interpreted as the removal of waste by slopewash is termed areal erosion by a number of other authors (Bulla 1954). According to Bulla, the processes of areal erosion are encountered on most slopes in most climatic zones.

In this latter sense, areal erosion implies the activity of water running downslope over a broad area, as opposed to linear erosion in river beds. This is based upon that meaning of the term erosion when restricted to erosion by waterchannels, and is something of a contradiction in terms, being extended by the use of the adjective areal to mean also a number of other things such as rainwash, sheetwash, slopewash, "ruissellement, Flächenspülung", etc. Slopewash by rainwater and meltwater has been more recently expressed by the unequivocal terms plusiation or plusionivation.

\section{1/5. CORRASION AND ABRASION}

1/5.1. In a broad sense, corrasion means mechanical wear of the substrata by waste transported in a moving medium. It is in this way that fluviatile, eolian, glacial, marine corrasion and mass-movement by gravity are distinguished (Baulig, Dylik, Holmes, Machatschek, Stamp, Strahler, Thornbury etc.).

In the narrow sense, the term is restricted to wind corrasion, the mechanical polishing action of sand grains flying in the wind (Derruau, Schaeffer etc.). Some other authors (W. Panzer) intend it to mean wear by cavitation in a current of water in a river.

The destruction wrought by waste and detritus moved downslope by gravity is also termed corrasion by several authors (Neef 1962, Scheidegger 1961, Bulla 1954, Penck 1924, etc.).

Some other authors interpret the term corrasion in a broad sense which, however, is different from the one outlined above. Moore (1962) considers corrasion to be mechanical wear by waste transported both in watercourses and by the wind. Gilbert (1877) employed it both for mechanical and chemical wear (dissolution). The latter effect is still termed corrosion, although some 
German authors mean corrosion to include also mechanical wear (Büdel, Machatschek etc.).

According to W. Penck (1924), corrasion is mechanical wear by detritus in the course of mass wasting. It is in his opinion frequently restricted to certain trajectories on the surface, in which case, broad and shallow valleys come to exist without permanent watercourses, or the profiles of pre-existing watercourses are flattened. Penck called these features valleys of corrasion and stated them to be most frequent near the valleyheads of normal erosional valleys with watercourses.

Stamp (1962) originally defined corrasion as the incising activity of watercourses. This point of view has also been adopted by some recent authors (Cotton 1952, Lobeck 1939, Strahler 1963).

A more precise interpretation is that of Holmes (1944), namely:

(1) corrosion is dissolution and chemical action by river water,

(2) hydraulic activity is the mechanical loosening and removal of fragments of the substrata by flowing water,

(3) corrasion is the wear and deformation of the bed and the banks of rivers,

(4) attrition is the mutual wear of transported waste.

Holmes also attributes these same four elementary activities to erosion by the sea. In this interpretation, as also in Bryan's (1922), corrasion occurs as an aspect of all processes of erosion.

1/5.2. Abrasion is employed in most of the German and in part of the French literature-alternatively also in the English-speaking world-to mean mechanical wear by waste moved by wave action and currents on the seashores (Baulig, Neef).

Some German authors also interpret the term to include the chemical and corrosive activity of sea water (Schaeffer 1959). Indeed, some extend it to the general-destructive plus constructive-activity of the moving masses of water in lakes and seas. Here instead of marine erosion, the term abrasion and its derivatives terraces of abrasion, levels of abrasion, plains of abrasion are employed (Ramsay, Richthofen, Johnson, Bulla, Grigoriev etc.).

Some others consider corrasion and abrasion to be almost synonymous, meaning wear by waste transported by the sea, rivers, wind and ice (Thornbury, Stamp, Scheidegger, Cotton). Flint (1947) is even more general and states that "abrasion is wear of rock by rock".

Hence, in the broad sense of the term, abrasion is the mechanical aspect of all erosive processes and similarly with corrasion. Although in some processes of erosion such as mass wasting or marine erosion, corrasion (or abrasion) may undoubtedly be the dominant factor, other aspects, such as gravity action, corrosion and hydraulic action will, notwithstanding, also be present.

The use of the terms fluvial and eolian corrasion, and marine abrasion is, consequently, appropriate and unequivocal only if they are considered as aspects of the respective processes of erosion. It would be incorrect to extend fluvial corrasion to mean all aspects of fluvial erosion, or marine abrasion to cover the totality of marine errosion or to employ these as interchangeable expressions. 


\section{THE CLASSIFICATION OF EXOGENOUS PROCESSES}

The several uses of the terms discussed above, all of which have broad as well as narrow meanings, render it necessary to elucidate the relationships of juxtaposition and subordination between the concepts covered by these terms. Some aspects of such a systematization were hinted at above in connection with their frequency of use, and original definitions or interpretations etc. It would, however, seem more expedient to present a hierarchy of the most important technical terms referring to the exogenetic processes in tabular form. As a basis of this hierarchical system, the present writer has accepted all the clear and unequivocal systematizations of the past. No new terms were included except where the interpretations of the existing ones were thought to lead inevitably to further misunderstandings (see Table 1).

The large-scale relief forms of the terrestrial surface are brought about in the first place by the action of endogenetic forces. The exogenous agencies tend to level the surfaces produced by endogenous action through the processes of destruction and accumulation. Since the endogenous forces tend to differentiate relief, the exogenous agencies will only become dominant during restricted intervals in time and space. The process of levelling is an irreversible one, although the exogenous agencies may locally result in dissection and resultant complexity.

The sum total of exogenous actions may be expressed by the comprehensive term smoothing of the relief. The literature uses the terms of regularisation granadation, planation, Ausgleichen for this same concept. W. M. Davis (1902) and more recently Thornbury (1954) employ the term gradation, but this usage has not become general. On the other hand, planation is employed in a narrow sense in most of the literature (see above). In view of the rather confusing use of the above enumerated terms in the different language areas, the present writer deems it justified to introduce the expression levelling of the relief (nivellation) for the totality of the exogenous processes.

The system of exogenous processes Levelling of the relief

NIVELLATION

DENUDATION

1. Eluviation physical chemical weathering

2. derasion collapsial colluvial delapsial solifluxial deluvial proluvial
SEDIMENTATION

1. detrition

eluvial

colluvial

deluvial

proluvial

2. accumulation fluvial alluvial marinelacustrine eolian glacial 


\author{
4. biogenic- \\ anthropo- \\ genic \\ 5. extra-terrestrial \\ meteorites \\ 6. volcanic bombs
}

\title{
REFERENCES
}

Baulig, H. (1956): Vocabulaire franco-anglo-allemand de géomorphologie. Paris.

Bryan, K. (1922): Erosion and sedimentation in the Papago Country, Arisona. U.S.G.S. Bull. 730. pp. 19-90.

Bryan, K. (1946): Cryopedology - the study of frozen ground and intensive frost action with suggestions on nomenclature. A. J. Sci., 244.

Bulla, B. (1954): Általános természeti földrajz (General physiography), II. Budapest.

Büdel, J. (1944): Die morphologischen Wirkungen des Eiszeitklimas im gletscherfreien Gebiet. Klimahefı der Geologischen Rundschau, Vol. 34, Nos 7/8.

Cotton, C. A. (1944): Geomorphology. An Introduction to the Study of Landforms. 4th ed. Christchurch, N. Z.: Whitcomb and Tombs, 1945.

Cotton, C. A. (1952): Geomorphology. An introduction to the study of landforms. London.

Davis, W. M. (1902): Base-level, grade and peneplain. J. Geol., 10, pp. 77-111.

Davis, W. M. (1955): Geographical Essays. New York.

Davis, W. M. and Snyder, W. H. (1898): Physical Geography. Boston.

Derruau, M. (1962): Précis de géomor phologie. Paris.

Dylik, J. (1964): The essentials of the meaning of the term of "Periglacial". Łódz.

Flint, R. F. (1947): Glacial geology and the Pleistocene epoch. New York.

Gilbert, G. K. (1877): Report on the Geology of the Henry Mountains. Washington: Government Printing Office.

Grigoriev, A. A. (1960-66): Kratkaya geograficheskaya Enciklopediya. 1-5. Moscow.

Holmes, A. (1944): Principles of physical geology. London.

Howell, I. V. (1957): Glossary of Geology and Related Sciences. Amer. Geol. Institut.

Jaks, G. V. (1954): Multilingual socabulary of Soil Science. Roma.

Kádár, L. (1954): A szél felszinalakító munkája. (Landscapeforming by wind) in vol. Bulla B. 1945, Általános természeti földrajz, II. pp $206-254$.

Klimaszewski, M. (1963): Geomorfologia Ogolna. Warszawa.

Leopold, L. B., Wolman, M. G. and Miller, J. P. (1964): Flusial processes in geomorphology. San Francisco-London.

Lobeck, A. K. (1939): Geomorphology. New York. Me Graw-Hill Book.

Machatschek, F. (1952): Geomorphologie. Leipzig.

Moore, W. G. (1962): A Dictionary of Geography. Penguin Books.

Murawski, H. (1963): Geologisches Wörterbuch. London.

Neef, E. (1962): Das Gesicht der Erde. VEB F. A. Brockhaus Verlag, Leipzig.

Nikolaev, N. I. (1958): Ocherki po istorii geologicheskich znanii Vypusk 6. Izd. A. N. SSSR. Moscow. 
Panov, D. G. (1966): Obshaya geomorfologia. Moscow.

Panzer, W. (1965): Geomorphologie. Braunschweig. G. Westerman Verlag.

Penck, W. (1924): Die morphologische Analyse. Ein Kapitel der physikalischen Geologie. Stuttgart.

Pécsi, M. (1964): Ten years of physico-geographic research in Hungary. Budapest.

Pécsi, M. (1966): Problemes quaternaires de la recherche géomorphologique des montagnes centrales intracarpathiques. Geomorphological Problems. Warszawa.

Rice, C. M. (1941): Dictionary of Geological Terms (exclusive of stratigraphic formations and paleontologic genera and species). Ann Arbor, Mich.,: Edwards.

Schaeffer, I. (1959): Allgemeine Geographie. Fischer Lexikon. pp. 15-35.

Scheidegger, A. E. (1961): Theoretical Geomorphology. Berlin-Göttingen-Heidelberg.

Schieferdecker, A. A. G. (1959): Geological Nomenclature. Gorinchem.

Stamp, L. D. (1962): A Glossary of Geographical Terms. London.

Strahler, A. N. (1963): Physical Geography. New York-London

Stshukin, I. S. (1961-1964): Obshaya geomorfologia. Tom. 1-2. Moscow.

Termier, G. and Termier, H. (1963): Erosion and sedimentation. London.

Thornbury, W. D. (1954): Principles of Geomorphology. New York-London.

Tricart, J. (1963): Géomorphologie des régions froides. Paris.

Vadász, E. (1953): Elemző földtan (Analytical Geology). Budapest.

Vendl, A. (1951-1952): Geológia (Geology) I-II. Budapest.

Wooldridge, S.W. and Morgan, R. S. (1937): Physical Basis of Geography. London: Longmans. 



\section{VARIOUS MECHANISMS OF INTERNAL MIGRATION IN HUNGARY}

by

B. SÁ R F A L V I

\section{INDUSTRIALIZATION-A STIMULUS TO MIGRATIONS}

The process of socio-economic restratification is an objective historical phenomenon. A migration-induced increase in the industrial population at the expense of the agricultural population must take place in every society embarking upon industrialization during its economic evolution. Industrialization in Europe generally began simultaneously with the full-scale development of capitalism, but a number of European societies were more or less passed by the winds of bourgeois revolution. Naturally, the development of the social division of labour came to a standstill in these countries. This was the case with some of the European socialist countries, in which no marked industrialization took place before the socialist transformation of these societies.

According to the setting-in and intensity of industrialization, and to the extent of social division of labour, the European socialist countries represent three different types. The distinction between the individual types is not essential, as distinctive features are due to historical phase differences in the industrialization of these countries.

a. The German Democratic Republic and Czechoslovakia belong to those regions of Europe, where both bourgeois and industrial revolutions were rudimentary processes which were historically delayed. Their industrialization was a very swift, and at some stages an even stormy process, and more than half of their population found employment in the non-agricultural branches of the economy before the coming of the 20th century. The role of industry is prominent in both the occupational distribution of the economically active population and in the production pattern of the various branches of the economy.

b. The second historical type is represented by the Soviet Union, Poland, and Hungary. Because of internal remnants of feudalism and partly because of dependence on other nations, these countries entered the final phase of bourgeois revolution and commenced industrialization as late as the 20th century. Although the foundations of their industry were laid in the first decades of this century, full-scale industrial development was essentially induced by socialist revolution, and the agricultural population only dropped below 50 per cent as late as the middle of our century. In the Soviet Union and Hungary the distribution of the gainfully employed population between industry and agriculture and the gross national product has now definitely tilted in favour of industry, but in Poland the agricultural labour force still outnumbers the population gainfully employed in industry. 
c. The third type is represented by the socialist countries of Southeast Europe which remained either completely or for the most part agrarian until the middle of the 20th century. The industrialization of these countries, apart from a few more advanced districts such as Slovenia and Croatia in Yugoslavia and Transylvania in Rumania, began only during their socialist transformation after World War II. Bulgaria and Albania (the least developed) also belong to this type.

Two stages of industrialization can be distinguished in Hungary: (a) capitalist industrial development prior to, and (b) socialist industrialization, after World War II.

A.The capitalist stage of industrialization witnessed considerable occupational restratification and urbanization. The agricultural population was progressively reduced in relative importance from the second half of the last century on, even though its absolute ratio still increased, although at an ever decreasing rate, until World War II. Whereas the total population increased by nearly 73 per cent between 1880 and 1949, the increase of the agricultural population was only 25 per cent. During the occupational restratification of this period different spatial types developed in Hungary.

1. In the areas of industrial development, which accounted for the smaller fraction of the country, two types can be distinguished:

a. Within the zone of direct industrial activity the agricultural population changed occupation in situ.

b. The agricultural residents of the areas adjacent to the industrially developing zones either moved to the industrial centres, or joined the commuters whose number had been increasing since the 1930 s.

2. In some areas the natural increase of the population drastically declined, and the agricultural population decreased, a process for which, however, industrial development was not responsible.

3. Over the greater part of the country, the relative density of the agrarian population per 100 hectares steadily increased, but striking differences appeared between certain areas:

a. Areas of slowly increasing agricultural population, and moderate outmigration where during 7 decades the number of people gainfully occupied in agriculture grew from 27 to 32 per 100 hectares.

b. Areas of markedly increasing agricultural population, and low rate of out-migration, where between 1880 and 1949 the agricultural population increased from 24 per 100 ha to $38-40$ per 100 hectares.

c. Areas of markedly increasing agricultural population, and insignificant out-migration where the density of agricultural population increased from 37 per 100 ha in 1880 to 50 per 100 ha in 1949.

B. Since 1949 socialist industrialization has accelerated the social division of labour and to a large extent Hungary has become an industrial country with an advanced agriculture. This decisive phase of socio-economic restratification had marked implications. The agricultural population which had stagnated at 50 per cent of the total labour force since 1910, dropped to 36 per cent by 1960 and to 31 per cent by 1965. As a result of industrial and associated investment, 1.4 million new non-agricultural working places were established, while the agricultural population decreased by nearly 1.5 million 


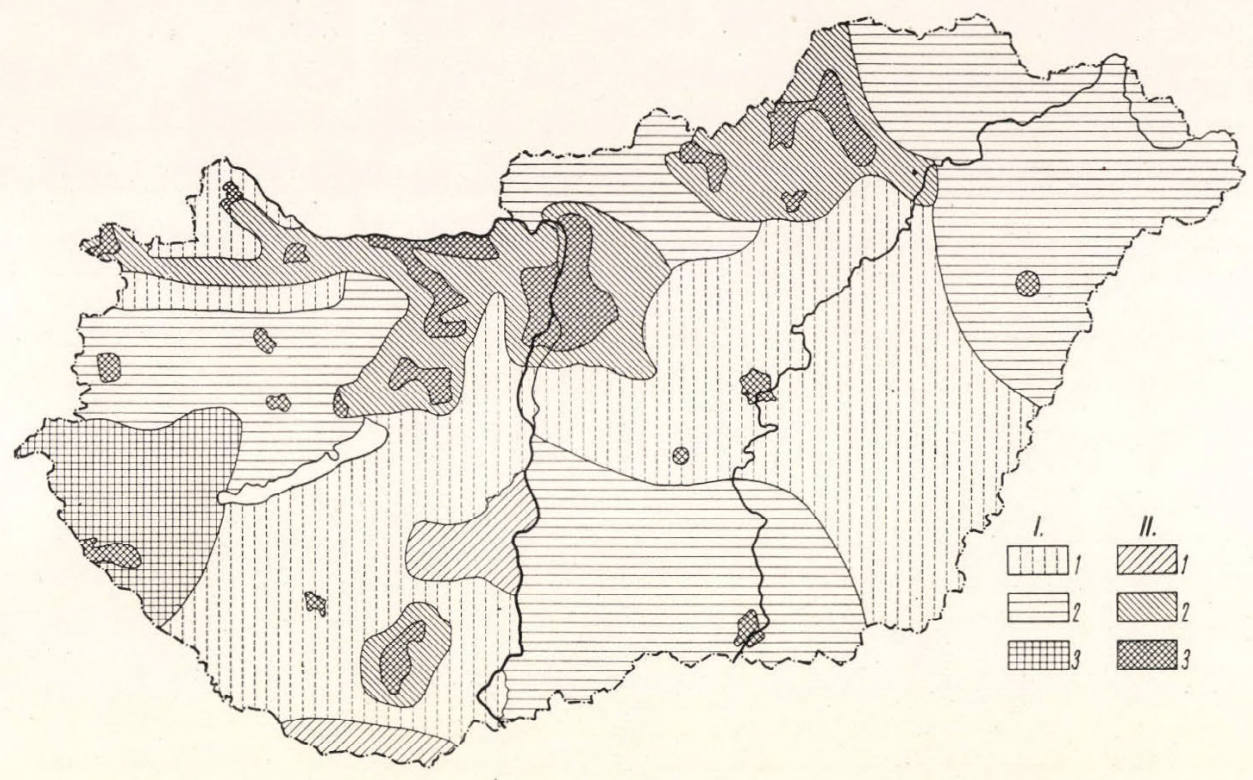

Fig. 1. Spatial types of social restratification between 1880 and 1949.

I. = Increase of agricultural population:

$1=$ slow growth (the number of earners per 100 ha has grown from 27 to 32 );

$2=$ marked growth (the number of earners per 100 ha has grown from 38 to 40$)$;

$3=$ rapid growth (the number of earners per 100 ha has grown from 37 to 50 )

II. = Decrease of agricultural population:

$1=$ because of low natural increase;

2 = because of out-migration;

$3=$ because of local restratification

and the number of people gainfully occupied in agriculture by more than 630,000 .

This process, however, did not only induce drastic changes in the structure of the national economy. By dividing the new material forces of production, it upset the equilibrium between the sectoral and areal structure of the national economy, giving rise to disparities between the geographical patterns of the material forces of production on the one hand, and the distribution of labour, on the other.

Consequently, the function of migration from the predominantly agricultural areas of the country to those industrially developed is to re-establish this equilibrium.

The 7 decades of pre-socialist industrial development had already established the spatial characteristics of social restrification in Hungary: the Central Mountain Belt, associated with the industrial concentrations along the Danube and in the capital, is opposed to the rural remainder of the 


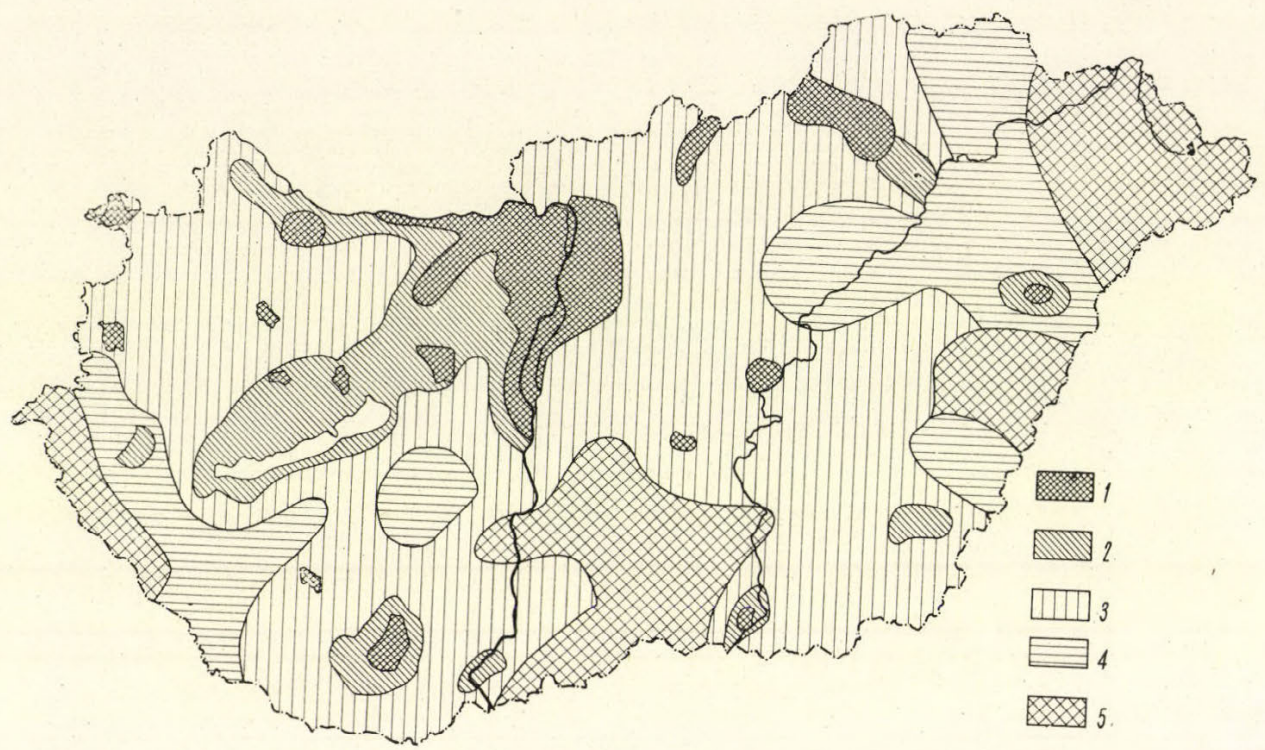

Fig. 2. Regional types of social restratification between 1949 and 1963.

1 = labour-absorbing, highly developed industrial district;

$2=$ labour-absorbing district industrially oriented;

$3=$ areas of commuting (dormitory areas);

$4=$ areas with modest out-migration;

$5=$ areas with considerable out-migration

country. Restratification during socialist industrial development has modified this geographical process in the following manner:

1. the traditional area of industrial concentration is much larger, although its nuclei have remained unchanged;

2. the concentration of industry, which controls the migration of labour, has grown in both space, and in intensity, the latter being more significant;

3. the rapid growth of industrial, servicing, and ancillary employment has given rise to widespread population movements from rural areas to the areas of industrial development.

The rate of industrialization during the socialist period has accelerated, and is unprecedented. During the capitalist stage of industrialization in Hungary, the fastest rate of growth was between 1890 and 1910, when nonagricultural wage earners increased by 2.8 per cent a year. During the $1930 \mathrm{~s}$ this figure dropped to 1 per cent per annum, whereas from 1949 to 1960 employment in the non-agricultural sectors increased by 5 per cent, and since 1960 by 3 per cent per year. 


\section{THE DIFFERENT MECHANISMS OF SOCIAL RESTRATIFICATION}

Social restratification, the change of occupation of the gainfully employed agricultural population and its absorbtion into industry and other nonagrarian branches, does not always involve large-scale migratory movements, and may proceed locally with negligable migration. Although this is one method of restratification, it could be used by only a small minority of the ex-agricultural labour force in Hungary, since even the areas of inflated industrial concentration contained but a fraction of the nation's area. In addition, the comparatively low number of new non-agrarian working places in the rural areas has not provided sufficient scope for local occupational change, although the development of servicing activites, as well as the cultural, public health, and social achievements in these parts of the country should not be underestimated. Settlements, where the number of nonagrarian wage earners have not doubled during the past fifteen years, are very few in Hungary; in most of the settlements this figure has at least tripled.

However, even though considerable progress has been attained in the cultural and social amenities of the provincial areas, only a small fraction of the labour released from agriculture could find local jobs. For this reason, not only did the number of the agrarian earners decrease, but the total population also declined by between 10 and 15 per cent during the period 1949 to 1965 . In the northeast part of the Great Hungarian Plain, however, this figure was less than 10 per cent. The smaller population losses there were not due to a lower rate of out-migration, but were attributable to a high rate of natural increase which balanced out-migration, even though the migratory losses were the highest in the country. During the 16 years just mentioned the population grew only in the area of industrial concentration (the Budapest agglomeration and the Central Mountain Belt).

Because of the lack of scope for local changes of occupation, the greater part of the labour force previously employed in agriculture were forced to leave their former residences either periodically, temporarily, or permanently.

Three main forms of restratification through migration can be distinguished: namely, commuting, seasonal migration and permanent change of domicile.

\section{COMMUTERS}

Because of their change of occupation, people attracted to industry commute daily to their new working places in another settlement. Commuting is a recent phenomenon. It does not set in, as a rule, until after full-scale social restratification has been attained, since its expansion is dependent upon the development of up-to-date transport facilities. Consequently, working places some distance away from the residences of the labour force have become accessible with the development of, first, railway and second, motor transport.

Yet commuting was not unknown in pre-liberation Hungary. Then, it was motivated by the extremely high price of building-sites within the cities (principally in Budapest), which thus effectively placed beyond the means of the 
workers and the lower paid white-collar staff, who consequently settled outside the municipal boundaries of the cities.

In $1930,3 \cdot 5$ per cent (some 140,000) of those gainfully employed were commuters. Later on, as a result of the rapid development of industry which was switching over to war production, the scope of commuting widened markedly, and the number of commuters increased.

During the 10 years of socialist industrialization, commuting assumed a rapid spread. In 1965 there were about 650,000 commuters who comprised 13 per cent of the active wage- and salary-earners.

Two types of commuters can be distinguished. First, there are those who are derived from the agricultural inhabitants of the suburban areas of the cities and the industrial centres. The second group is made up of those people who have moved from remoter parts of the country and who have resettled in the suburban areas due to housing shortages within the cities themselves.

The commuters have settled on the peripheries of the cities and industrial centres. Depending on the nature and stage of development of the communication network, the foci of attraction have been surrounded either by circular dormitory belts or by radial lines of dormitory settlements, stretching a considerable distance along the arteries of communication and transport.

Zones of commuting have been ranked according to the intensity of commuting, as measured by the ratio of commuters to the total gainfully employed population as follows.

a. A coherent dwelling or dormitory ring (inner belt of commuting) has developed around the Budapest agglomeration only, and more than 60 per cent of the gainfully occupied inhabitants of these settlements commute to the capital to work. The settlements within this belt have almost completely discarded their rural characteristics and have been transformed into dormitory villages.

b. Budapest's inner belt of commuting, as well as the provincial industrial centres, are surrounded by a zone of settlements in which some 45 to 60 per cent of the gainfully employed inhabitants are commuters. The largest zone of this type surrounds the capital, while the city of Györ and a number of the industrial centres in the Central Mountain Belt have become commuting centres of similar intensity, although supplied by smaller dormitory areas. Settlements of this type are two-sided, since their dormitory character is supplemented by the survival of some of their original agricultural functions.

c. Around the hitherto-mentioned commuting nodes and in the zone where industry is highly concentrated, as well as around almost every other town, between 20 and 45 per cent of the gainfully employed population are commuters. Exceptions to this rule are those Great Plain towns in which industrial development has been very modest. These typical market-towns of the Great Plain region have mainly trading, cultural and administrative functions.

d. Commuting of between 5 and 10 per cent of the gainfully employed inhabitants is a phenomenon common, by and large, to the whole of Hungary. However, there are some relatively large areas in the eastern part of Transdanubia, in the southern half of the Danube-Tisza Interfluve and in the region east of the Tisza which are not affected by the process. 


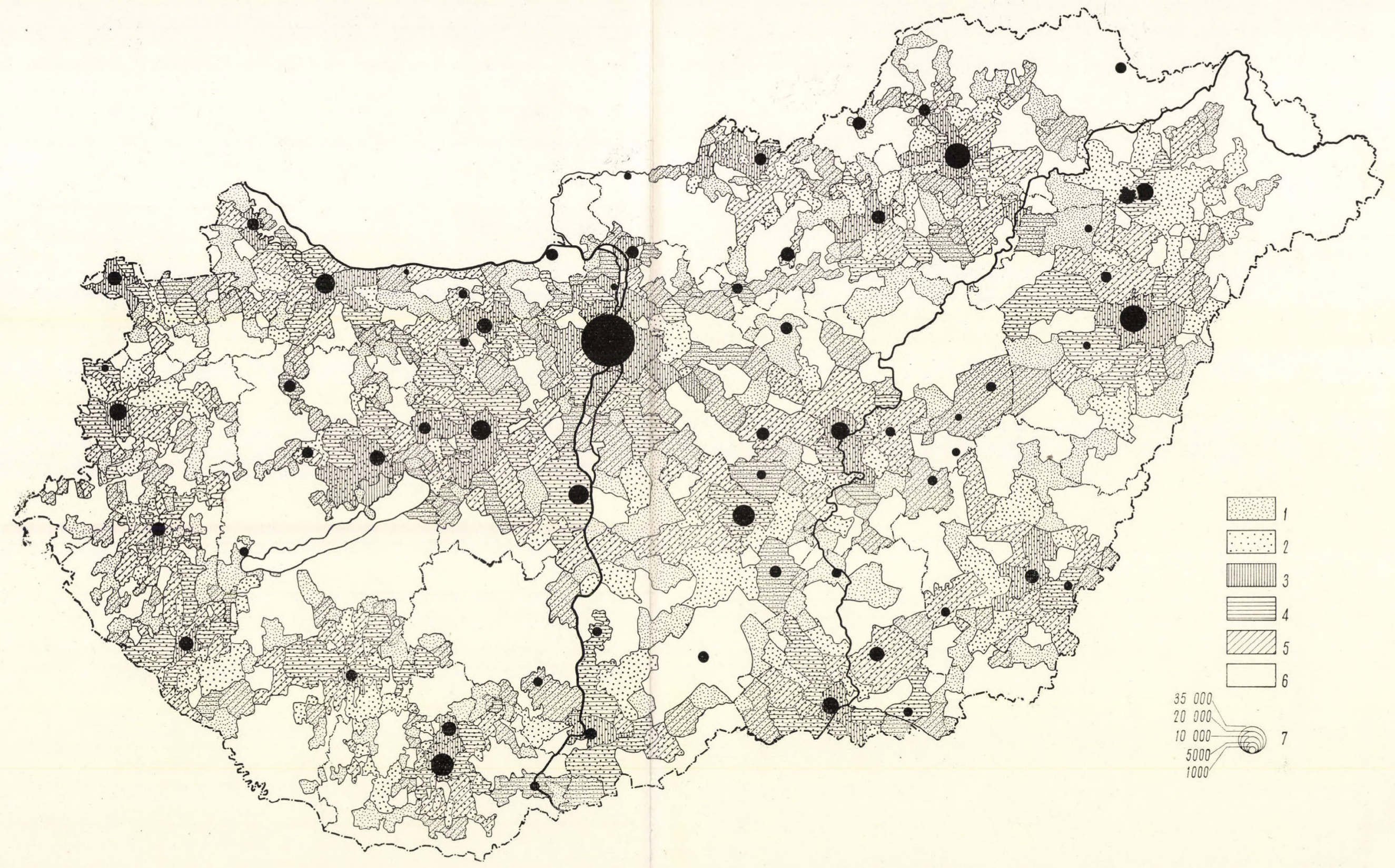

Fig. 4. Suburban areas "screened from towns" in 1962. (The number of people commuting to the centres of attraction is proportional to the area of the circles.)

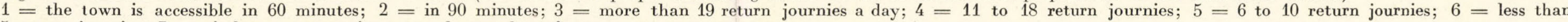
5 return journies; $7=$ circles are proportionate to the number of commuters to towns 


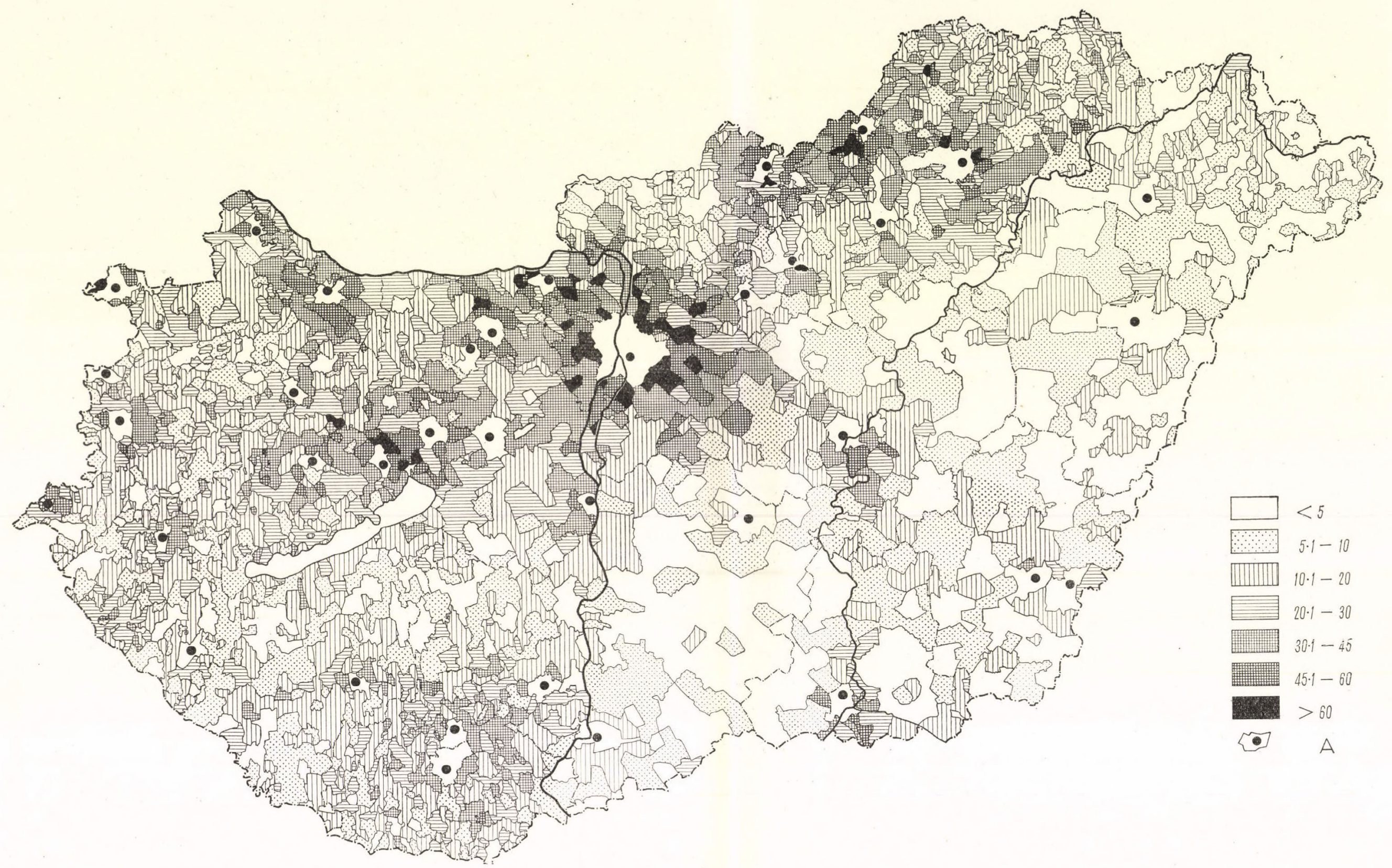

Fig. 3. Percentage of commuters to the total gainfully employed population, 1963.

$A=$ labour-absorbing settlement 
The distribution of commuters by profession and by age and sex is distinctive; 86 per cent of all commuters are manual workers and only 14 per cent are employed in the professions. Similarly, there is a great disparity between the sexes, as only 19 per cent of all commuters are female. As far as age distribution is concerned, 73 per cent of all commuters are within the 14 to 39 age group, whereas only 55 per cent of the total gainfully employed population is between these ages.

Commuting distances tend to be rather large. Only 25 per cent of all commuters work within their own municipal district, whereas 63 per cent travel to jobs at some other place within the same county, and 12 per cent commute out to working places to some other county. The majority within the last group, however, are not daily commuters and only return to their homes at week-ends, or even less frequently.

\section{SEASONAL MIGRANTS}

The distinction between regular commuting and seasonal employment is rather obscure, particularly in the building industry. Although this industry provides year-round employment for its permanent staff, less auxiliary labour is used in the winter, owing to the seasonal character of the industry. A large body of seasonal labour is necessary for the sugar- and canning factories, for the recreational facilities at the resorts and in the parks in summer, and to maintain the heating systems in winter. The sugar and canning factories usually solve this problem by employing part-time workers, while the major resort districts, for example Lake Balaton, and the Mátra Mountains, enrol seasonal workers from among the inhabitants of the near-by agricultural areas.

Although considerable at present, the need for seasonal labour in agriculture for the fruit and crop harvests in the autumn will continue to grow at a rapid pace with the expansion of horticulture and with the growth of vine and orchard plantations. Yet these needs are not being met today, except perhaps on the state-run farms where some 20 to 30 per cent of the labour force are seasonal workers. Accordingly, although some of the prerequisites are present, e.g. regular occurrence of labour demand, the presentday volume of seasonal labour migration is insignificant.

\section{PERMANENT MIGRANTS}

The most effective mechanism bringing about the socio-occupational restratification of the population is a permanent change of residence. This migratory process directly influences commuting, since many commuters have moved to a new residence at the same time as changing occupation. In terms of the 1960 census, 18 per cent of the population over the age of 11, a total of 1,474,000 persons, changed residence since 1949; and between 1960 and 1965 the number of permanent migrants exceeded 300,000 annually. As far as the sex differential is concerned, male migrants slightly outnumbered female migrants, 51 and 49 per cent, respectively, between 1949 and 
1960. The majority of permanent migrants were young adults, while the number gainfully employed (almost one million) was larger than the national average, i.e. $68 \%$ and $63 \%$, respectively. The village populations have been most mobile forming $73 \%$ of all permanent out-migrants, but although more than half moved to other villages, this inter-village migration was directed towards settlements close to the zone of industrial concentration. The intensity of migration from the villages was such that 21 per cent of village dwellers migrated between 1949 and 1960. The corresponding figures for the district towns, the provincial cities and for Budapest were 18, 16 and 9 per cent, respectively. But even though there has been considerable intervillage migration, the main migratory trend has been from the village to the town. This conclusion is borne out by the fact that most of the migrants from the towns and the cities have re-settled, in other towns and cities.

Nationally, inter-territorial migration has been predominant among the population within the economically active age groups. One third of the 20 to 29 age group $(32.6 \%)$ and nearly one quarter $(23.6 \%)$ of the population between the ages of 30 and 39 changed residence. For the village population only, the contrast is even greater and the respective figures are, 38 and 26 per cent (1949-1960).

Trends and rates of socio-occupational restratification are characterized by the following data: 22 per cent $(307,000)$ of all industrial employees, 23 per cent $(70,000)$ of employees in the building industry and 22 per cent $(64,000)$ of those employed in communications migrated between 1949 and 1960. Intra-agricultural migration was also intense during the period and 11 per cent $(202,000)$ of the active agricultural population changed residence. This latter process was the result of fluctuations due to the collectivization of agriculture rather than being associated with areal specialization in agriculture.

Inter-regional migration during the 100 years preceeding 1949 was considerable, but the spatial polarization of the population which culminated between 1949 and 1965 was the result of large-scale industrialization. Naturally, people went on migrating from the areas which had been affected earlier by this process.

The Great Plain region suffered the greatest losses through migration and only a few towns and cities can boast of a positive migration balance, while on the east and south borders of this region there are scores of settlements which have been abandoned by thousands of inhabitants during the past decade.

Only three cities on the Great Plain have attracted marked numbers of settlers, namely Debrecen, Szeged and Szolnok.

The industrial zone of Hungary extends from Zala County in the southeast passing through the capital and the Northern Industrial District to Miskolc in the northeast. All of the industrial settlements within this zone have attracted great numbers of migrants, its individual units are not contiguous, but are connected together rather as the links of a chain, stretching to the city of Győr in the west and to Dunaújváros in the south. They are joined on both shores of Lake Balaton by the lake-side resorts which have also acted as migration nodes. During the past decade, in the resorts of 
Siófok, Balatonfüred, Fonyód, and Keszthely in-migrants exceeded outmigrants, the balance being greater than for many of the towns of the Great Plain. On the other hand, the peripherial areas of Transdanubia are uniformly characterized by a negative migration balance, and only the industrial districts of Pécs and Komló and a few isolated towns have shown a surplus of in-migrants. In this region also the small villages have been abandoned at a very high rate.

Of all the cities and towns in Hungary, Budapest has by far the highest number of in-migrants. They have settled partly within the municipal area of the capital, and partly within its immediate vicinity. The settlements around the capital form two belts. In the immediate vicinity of Budapest the settlements are comparatively overpopulated and still growing due to in-migration. The number of migrants to these settlements exceeds the values for many towns. Resettlers from the agricultural areas of the country have added to the commuters from this zone. Farther away from the capital, the rate of in-migration gradually decreases. The settlements of the outer belt have not been attractive to migrants and part of their population, particularly of the minor villages, has settled in, or closer to, Budapest.

Budapest and its immediate vicinity, including the county of Pest, has been a magnet for migrants from almost all parts of the country, although most of its new labour force has come from the Great Hungarian Plain which accounts for 48 per cent of the gainfully employed settled within the Budapest agglomeration (1949-1960). The capital has two-way connections with the rest of the country. Although its rate of out-migration is substantially lower than its in-migration, the entire area of the country is affected by the process. One point should be borne in mind, however: whereas half the migrants to the capital have come from the Great Hungarian Plain, the majority of Budapest's out-migrants $(76 \%)$ have moved to Transdanubia or to industrial counties in the north.

\section{THE SPATIAL PATTERN OF THE RESTRATIFICATION PROCESSES}

After the above review of the types of spatial mobility involved in the socio-occupational restratification and geographic redistribution of the population, an analysis of the various forms of migration and their interrelationships is also indispensable for an objective and better understanding of the internal migration process. The different migratory mechanisms are neither independent of one another nor of the geographical distribution of the material forces of production.

The study of inter-regional migration to and from the most important areas of employment concentration, as well as the transport network between and within these areas, leads to the preliminary conclusion that the predominance of any particular restratification process in an area depends on the local conditions effecting employment-change.

The labour-absorbing areas, of intense in-migration in depict all three migration processes. In such areas, changes of occupation in situ and commuting 
are juxtaposed and even combined, as both are basically dependent on spatial concentrations of employment, which are either local or easily accessible. Once developed, such concentrations are gradually surrounded by commuter zones. The latter, however, are, on the one hand, areas losing labour since their own ex-agricultural labourers commute to the industrial centres and, on the other hand, areas of labour absorption, since they attract migrants from remote agricultural areas because resettlement is both easier and cheaper here, only to transmit them as commuters to the industrial centre.

The geographical pattern of out-migration is the opposite to that of commuting. Whereas the latter is important in the areas of industrial concentration, as well as around Győr and Pécs and the Lake Balaton resorts, which are employment centres of almost equal rank, the rate of out-migration is most striking in the areas that are said to be "screened from the town". These areas either lie so far away that the town or city cannot be reached in 90 minutes, or, though close to town, lack the necessary communication facilities. Of course, one has to take into consideration that the towns may differ in their centripetal energy, i.e. that towns, as centres of employment, are of different importance. For example, when non-agricultural employment in towns is small, even though optimum communication facilities may exist between it and the suburban area, commuting will be unable to absorb completely the ex-agricultural labour force. For this reason, even the immediate vicinities of a few comparatively underdeveloped towns behave essentially as areas "screened from towns", and are the scene of continuous out-migration.

On the basis of the interrelations between the various types of spatial mobility, three basic areal types of population restratification have been distinguished in Hungary.

a. In the contiguous zones of industrial concentration the possibility of reaching the central working areas in a short time, i.e. 60-90 minutes, as well as frequently, i.e. 25 return journies by train or bus a day, is combined with intensive industrial activity. In these areas the occupational restratification of the population takes place on the spot or in settlements within reach of local transport, through commuting. Depending on the extent of non-agricultural employment, local ex-agricultural labour is either partly or completely absorbed, and is continually being added to by new migrants from remote areas.

b. Isolated, minor concentrations of employment where the communication facilities are excellent, but the number of non-agricultural working places insignificant. In the vicinity of these industrial foci, restratification consists of a rather low rate of commuting combined with some out-migration. Commuting is found in the immediate vicinity of the towns only, since labour released from the areas farther away (between 5 and 15 per cent of the total gainfully employed population from 1949 to 1960) migrates to the zone of industrial concentration.

c. Over the rest of the country both the necessary communication facilities and the labour-attracting towns or industrial concentrations are absent. The only method of restratification is permanent migration. The eastern, southern and western borderlands and a part of the northern region of Hungary belong to this category. Between 15 and 25 per cent of the population 
in these areas have moved away permanently and, for lack of near-by industrial foci, this migration is on a regional scale.

\section{REFERENCES}

Cépédé, M. M. (1959): La société rurale et les problems actuels de l'exode rural. Les migrations rurales. Premier Congrés de la Societé Européenne de Sociologie Rurale. Bruxelles-Louvain.

Hagerstrand, Th. (1959): Rural Demography. Les migrations rurales. Premier Congrés de la Societé Européenne de Sociologie Rurale. Bruxelles-Louvain.

Lettrich, E. (1964): Urbanization of Hungary in the light of the occupational structure of her population. Applied Geography in Hungary, Budapest: Akadémiai Kiadó, Studies in Geography No. 2.

Sárfalvi, B. (1964): Internal migration and decrease of agricultural population in Hungary. Applied Geography in Hungary, Budapest: Akadémiai Kiadó, Studies in Geography No. 2.

Sárfalvi, B. (1967): Population decrease in the Hungarian agriculture. Abstract No. 8. MTA Földr. Kutató.

Winberg, I. P. (1959): Net migration and rationalisation in agriculture in the thinly populated districts of Southern and Central-Sweden. Les migrations rurales. Premier Congrés de la Société Européenne de Sociologic Rurale. Bruxelles-Louvain.

The effects of industrialization on the agricultural population in the European Socialist Countries (1967). Papers of the Symposium on Population Geography held at Budapest, 1967. Oct. $18-22$. 



\section{THE HUNGARIAN TANYA* SYSTEM: HISTORY AND PRESENT-DAY PROBLEMS}

by

E. L E T T R I C H

The Hungarian tanyas represent a settlement and farming system unique in Europe. Externally, they hardly differ from the habitual forms of scattered rural farmsteads, but when their genesis, economic functions and geographic aspects are considered, however, their individualism is conspicuous.

The Hungarian tanya is a settlement form typical of the Great Hungarian Plain and is of great importance for agricultural production. In the central and level plain of some $30,000 \mathrm{~km}^{2}$, the characteristic settlement pattern includes widely spread "giant villages" or market-towns and detached, isolated farmsteads or tanyas, which dot the hinterland of the former with varying density.

The present tanya system of the Great Hungarian Plain appeared in the 18th and 19th centuries, though its historical roots can be traced back to the rule of that part of Hungary by the Turks in the $16 \mathrm{th}$ and $17 \mathrm{th}$ centuries. During the more than 150 years of Turkish occupation (1526-1689) the settlement pattern of the Great Hungarian Plain was substantially changed, partly for reasons of defence, partly because of changes in the economic conditions. As a result of population losses, due to warfare and deportations, the comparatively dense pre-Turkish village net became strikingly wide-meshed. As feudal properties, the settlements of the occupied areas fell prey partly to Turkish lords of various rank and description, and partly to the sultan's treasury. Some settlements, such as the so-called Khas towns, were relatively free and legally independent, and their inhabitants were fairly well protected. Consequently, the population of near-by villages and of more distant ravaged settlements sought safety in these major settlements, and the population of the desolate outskirts of the abandoned villages tended to join the hinterland of such places. The widely-spaced giant villages of the Great Hungarian Plain - some of which have become agrarian towns-were established that time. Even these comparatively large concentrations did not comprise more than 5,000 to 10,000 persons, but because of the incorporation of the areas of the destroyed villages, the outskirts of these settlements grew to between 100,000 and 150,000 hectares. Over this vast area, distinct farm-

\footnotetext{
* On the Great Plain, the peasantry of the large agrarian towns, with extensive fields attached to them, built farmsteads for themselves to complement their town dwellings, these farmsteads were widely scattered in the vicinity of the town. The farm buildings stood isolated from one another or in groups, while in some regions they formed straight lines along the roads across the fields.
} 
ing and settlement types developed, which adapted themselves to the particular historical background.

Crop production was largely pushed back, and tilled land shrank to a minimum in the Great Plain. The wide expanses of the puszta were used for extensive stockbreeding, upon which a busy cattle trade was based. Suitable for trailing for great distances, wild cattle became the main source of income for the inhabitants of the giant villages and market-towns.

This form of cattle-breeding, wide-spread throughout the Great Hungarian Plaiu, produced a marked effect on both the internal and external settlement structure. The nucleus of each settlement was formed by the random agglomeration of unfenced dwelling houses (Fig. 1). Farm buildings such as stables, farm-yards, granaries, etc. were located away from the dwelling houses and formed a wide circular belt of stable enclosure around the village. Thus in a socalled "divided settlement system" each farming family had two plots-one in the centre of the settlement where the dwelling house stood, and another in the stable enclosure. Hence the name- "divided settlement system". The stable enclosures were surrounded by the inner pasture zone used for the grazing of dairy cattle and draught animals. Here and there, vineyards and kitchen-gardens wedged into this zone, beyond which lay the cropland. The tillage of land was rather limited and was run, for the most part, on private holdings determined by right of first seizure; on rare occasions, the land was held communally and a rotation of crops was used. The size of the tilled plots was often so small that no coherent cropland ring could develop around the village, and in such places, the inner pasture was in direct contact with the outer pasture-the vast expanses of the desolate puszta where extensive cattle-breeding was run. Both herds and herders lived outdoors throughout the year, although in winter they went to their "puszta winter quarters". In these, there were no permanent buildings but unthatched, fenced spaces for the cattle and temporary huts for the herders. These could be easily displaced once the surrounding area was grazed up and the herds had to move to new pasture. The order of grazing was strictly stipulated by the council representing the cattle owning community, from which the herders were not allowed to deviate. In the 17 th century there also were a few private pastures of considerable size, the number of which gradually incraesed, until by the end of the century, they were more numerous than the common pastures.

Consequently, economic life was based primarily on stockbreeding and the cattle trade, and agriculture, viniculture and industry were of a subordinate and subsidiary nature. Most of the settlements were dependent on grain crop supplies bought from somewhere else. On the other hand, the cattle stock supplied to distant markets was immense.

The rules of ownership were not governed by the system of serfdom. It was essentially a free, bourgeois holding system which was, however, restricted and ruled by the civis communitas, a community exercising landlord rights. A distinct society was built upon these economic foundations. Rather than being a rural-serf society, it was more akin to the craftsman-merchant system which here was based upon stockbreeding-trading activities. In this so-called "civis society", both wealthy and minor farmers were essentially free citizens and could freely change domicile. Moreover, their wealth was inheritable. 
They hired large numbers of herders and fieldhands, and the form was kept together by extended family ties, as the married sons did not leave the family, but collectively ran the undivided farm.

Freed from Turkish rule towards the close of the 17th century, the population of the Great Hungarian Plain could live a more peaceful life and increase at a fast rate. New villages were created by the score, and were settled by Hungarians from other parts of the country, as well as by people from the German- and Slavonic-speaking areas of the Country. German settlers were also brought in from outside the Country. These new inhabitants were serfs under seignorial jurisdiction, but the majority of the Great Plain settlements which survived the Turkish era, still preserved their legal independence, and their inhabitants were exempt from feudal restrictions of right. The population of these settlements grew rapidly, as their legal advantages and privileges were attractive to new settlers.

In the 18th century the extensive stockbreeding on the puszta gradually declined, and the pastures were converted into arable land. Agriculture rapidly expanded and arable land quintupled between 1720 and 1780. Mainly grain crops were produced, the development of which was promoted by the favourable tendency of the grain market both in Hungary and abroad.

The marked changes in the structure of production induced changes in the mode of settlement. The divided inner structure of the settlements into stable enclosures and a belt of dwelling plots was gradually transformed with the stable enclosures becoming outdated, due to the decline of livestock production (Fig. 2).

As a result of the expansion of arable land, cultivation was extended progressively to the more distant parts of the hinterland. Consequently, it was no longer possible to commute daily to work because the plots which lay sometimes 25 to $30 \mathrm{~km}$ away from the dwelling house, and the farm-yards in the stable enclosures could no longer meet the requirements of the new mode of production (large space, good access, etc). For this reason, the farmers preferred to dwell temporarily on their private land plots while working there, which meant the transference of draught animals and the construction of permanent stables and granaries, etc., which could also provide temporary dwellings for people who worked there.

So the farm structures, which were transferred to the arable plots, necessarily became temporary dwelling places, giving rise to tanyas. During this first phase of development the tanya took over the function of the former stable enclosures of farm-yards, and adapted it to the needs of agricultural production. It was not an independent settlement, but a mere outpost, and an accessory element of the inner settlement. The tanya owners did not abandon the village, since their permanent dwelling houses still remained there.

The right of building a tanya, however, was restricted to those farmers who had household plots in the village and arable land plots in its outskirts. However, it must be stressed that nobody was allowed to move permanently from the village to a tanya at that time.

During the 19th century, large-scale river regulation, including flood control and artificial drainage, was carried out in the Great Plain. With the regulation of the Tisza and Körös rivers, nearly $2 \cdot 5$ million hectares of land were reclaimed 
(Fig. 3). The one-time habitat of fishermen and wild fowl hunters ('pákász') shrank and was gradually turned into farmland. The flood-controlled areas of the Great Plain were partly added to the area of the newly created feudal villages whose residents also began to build tanyas on their distant arable land plots. Initially rather restricted by feudal conditions, this process attained its full-scale development in the middle of the century after feudalism had been abolished and the peasants could build tanyas on their own landed properties.

During the second phase of tanya development in the first half of the 19th century, the tanya system of farming and settlement became general throughout the Great Plain. As agricultural production became intensified, shepherding was gradually replaced by stabling and the permanent habitation of the tanyas became unavoidable. With the growth of the economic importance of the tanya as a centre af farm operations, the seasonally inhabited farm outposts developed into permanent dwelling places. From the second half of the 19th century on, in the third phase of tanya development, the tanyas were permanently inhabited. This process is essentially connected with the break up of the large family system. According to the new order of inheritance, the holding was distributed among the farmer's children who built new tanyas on their inherited plots and permanenty settled there. They no longer had houses in the village. These permanently inhabited tanyas were spared between land $3 \mathrm{~km}$ apart and mostly lay on small holdings. During the third phase, they had but very loose ties with the near-by village or market-town.

Somewhat different from the above-outlined general pattern of development was the case with some Great Plain areas where marked local peculiarities made themselves felt in the shaping of the tanya system. Such areas are, for example, the Kiskunság and the Nyírség where the tanya pattern is cluster-like.

On the sand puszta of the Kiskunság, lying within the Danube-Tisza Interfluve, shepherding survived for a long time. The sandy soil of low fertility was unfavourable for the growing of grain crops, the production of which could spread only moderately in the 18 th and 19th centuries. Extensive stockbreeding on the puszta of the Kiskunság was not abandoned until the wide-spread development of vine- and fruit cultivation in the early decades of the 20 th century, a process which created a dense tanya network throughout the area.

The historical roots of the tanyas of the Kiskunság go back to the system of so-called "field gardens" developed there in the 16th and 17th centuries. These were periodically cultivated plots of arable land closest to the mainly privately owned winter quarters of the puszta-trailing herds. The importance of agriculture in such areas lagged far behind that of puszta shepherding. The mid-18th century forerunners of the tanyas of the Kiskunság were the farm buildings and temporary dwelling huts or houses built on these arable plots by the owners who lived in the towns and which appeared like minute dots amidst the vast grasslands. The present-day dense tanya network of the region, however, is younger and is connected with the introduction of horticulture in the 20th century. 


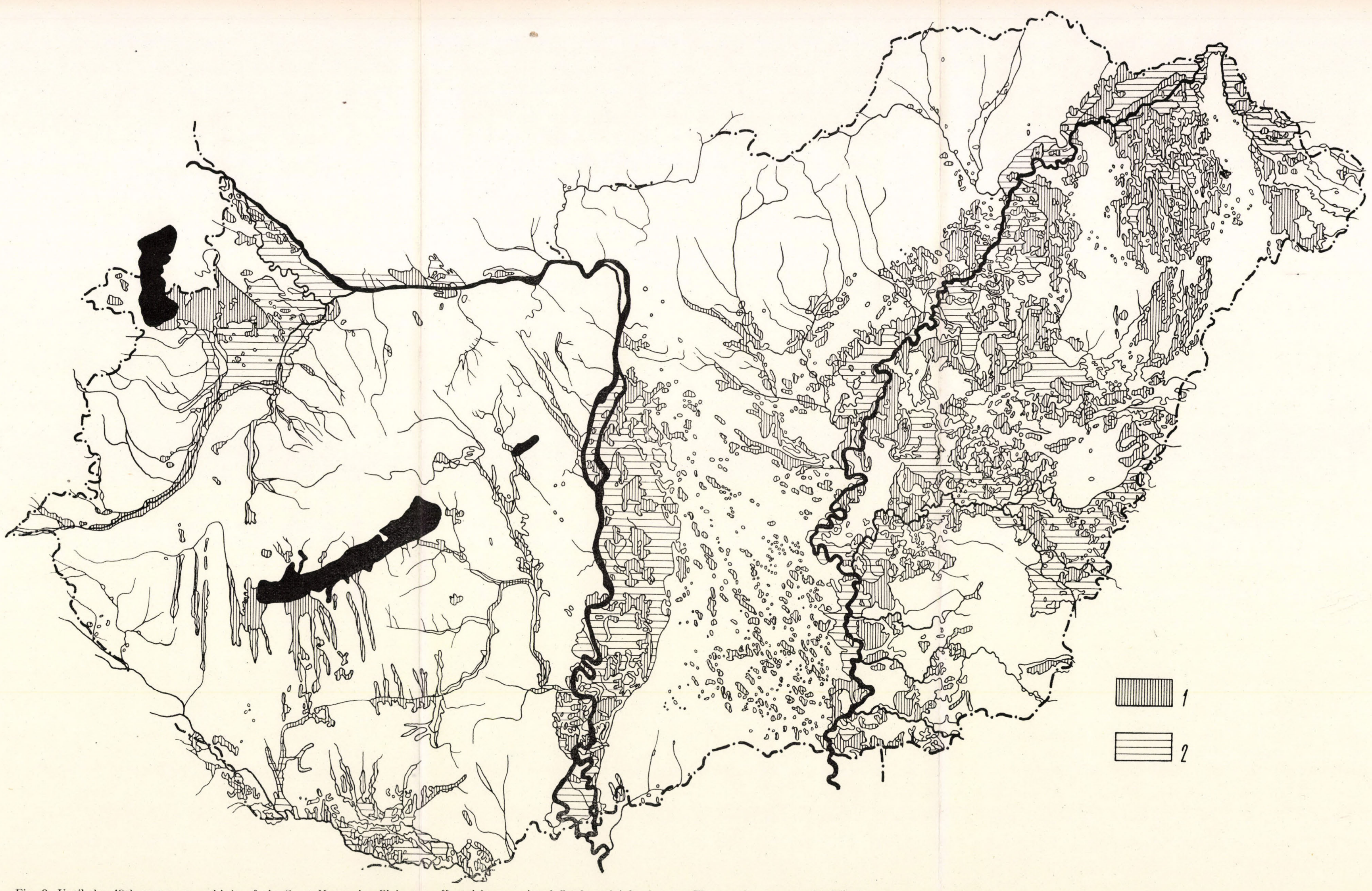

Fig. 3 . Until the 19 th century two-thirds of the
$1=$ flood-plain; $2=$ temporarily inundated area 


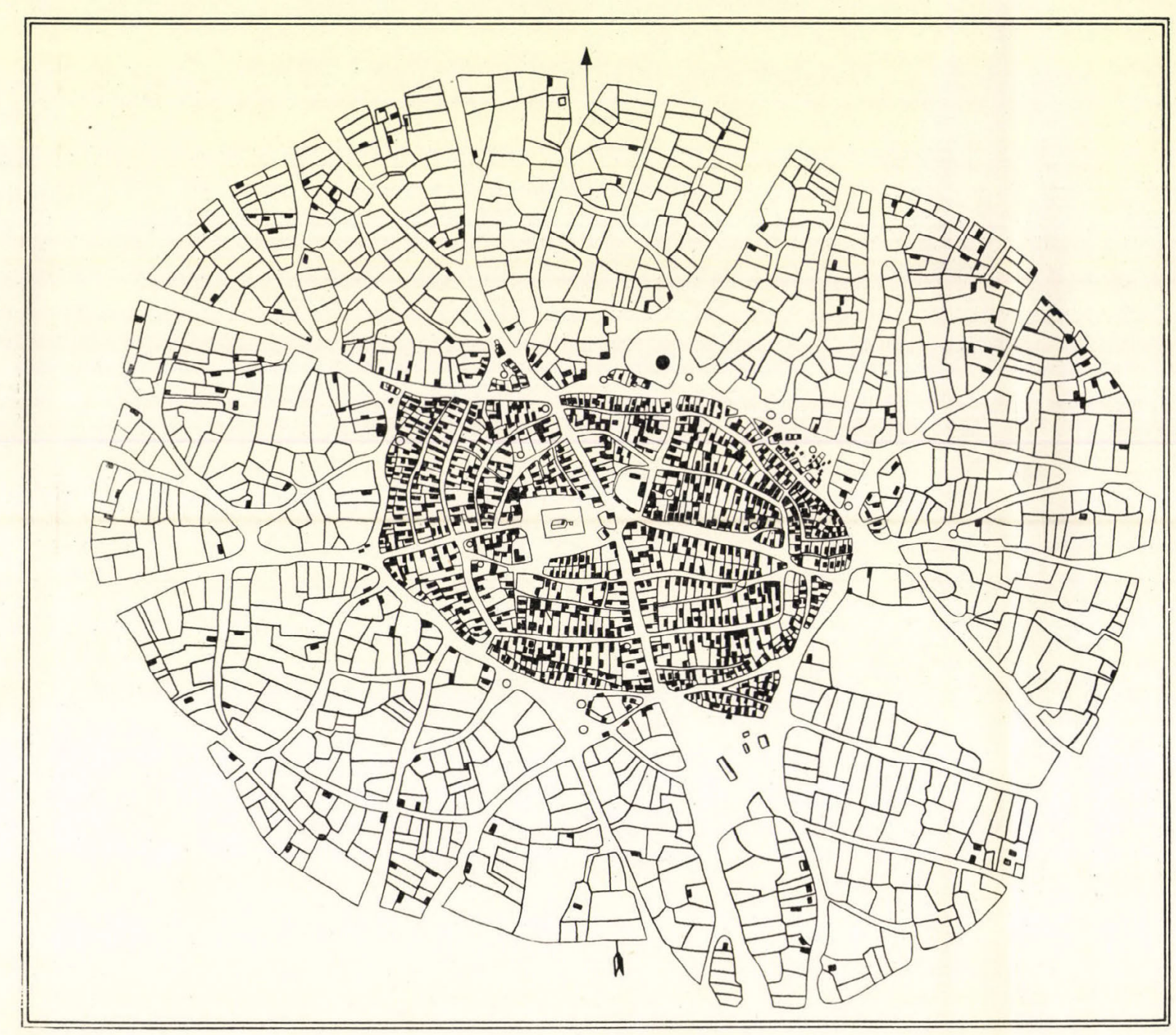

Fig. 1. Schematic map of Hajdáböszörmény in 1782. A wide zone of stable enclosures encircles a group of
dwelling houses, (After I. Györffy)

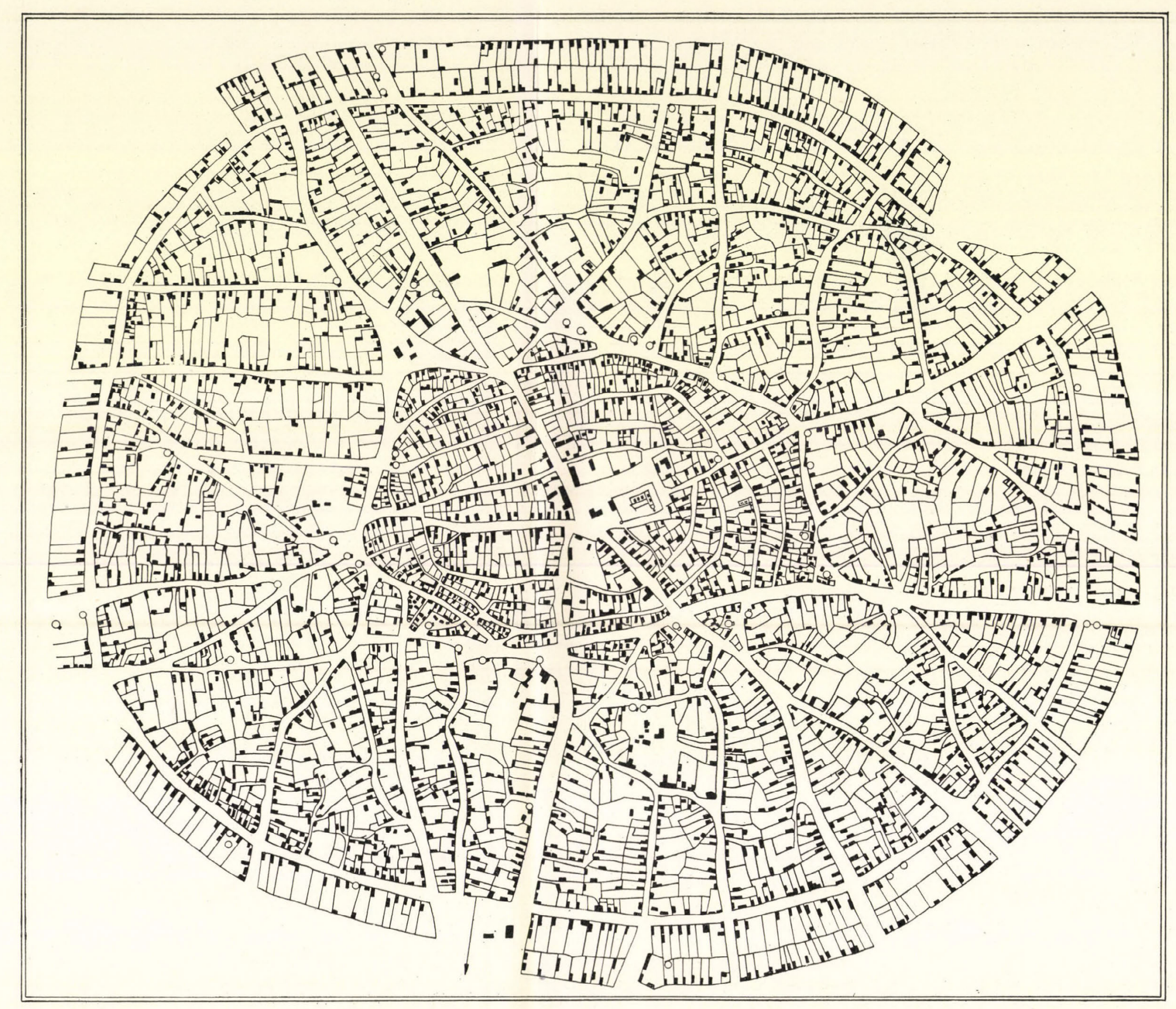

Fig. 2. Schematic map of Hajdúböszörmény in 1842. The zone of stable enclosures already broken up is being gradually occupied by dwelling houses. Facing page 154 
The cluster-like tanya groups of the Nyírség also differ from the general character of the Great Plain tanya system. These are Weiler-type hamlets, consisting of 4 to 5 or, occasionally, 8 to 10 tanyas. Their formation has been largely promoted by the intensification of agriculture, for example, by the introduction of tobacco cultivation.

In the 20th century, nearly 1 million of the inhabitants of the Great Plain have lived in tanyas. As a result of tanya farming, all the utilizable land of formerly desolate and sparsely populated areas could be harnessed for agriculture. The tanya system has thus greatly contributed to the development and intensification of agricultural production in Hungary. Garden cultures have in many places been intimately linked with the presence of small tanya holdings, without which these intensive forms of land utilization could not have been introduced. The tanyas have provided living for thousands of small holders, and although the living conditions of farmers on those, sometimes 20 to $25 \mathrm{~km}$ away from the village or town, were very adverse, they were better placed than the landless agrarian labourers including the tanya-dwelling workers of the big estates. Indeed, the people of the latter-mentioned class had to work on the tanya plots for very low wages, since Hungary had a large agrarian labour surplus. There were, however, thousands who were either completely unemployed or were only periodically hired, and whose fate was even harder.

The tanya problem has been of public concern even since the 1930s, but it could not be solved under the socio-economic conditions existing in the pre-Liberation period, and thus has been bequeathed as an unwanted legacy to socialist Hungary.

The reform of 1945 made land available for most agrarian workers and the majority built houses on their allotted plots. In this way, some 75,000 new tanyas were built, and the hired hands of the big estates joined the uniform stratum of tanya-dwelling small farmers. Lacking standard farm equipment, the newly created tanya-owning peasantry could only attain a low rate of cash crop production. These small farms, however, had to provide food for the growing industrial population of Hungary; the solution of the problems connected with the increasing agricultural production and the intensification of industry presented tasks that proved more and more difficult to fulfil under the given conditions of small-scale farming. Progress could only be achieved by creating socialist collective farms.

The conditions for such developments were, however, not the same for the entire area of the country. Marked differences in the degree of the development of the cultural landscape existed between Transdanubia and the Great Hungarian Plain. Despite the fact that after the Turkish occupation from the 17th century on, the Great Plain was the scene of marked progress, the region could not overcome its handicap. This was partly due to the unfavourable physical environment such as the extreme climate, the vast sand- and sziksoil areas and the poor hydrography, which drawbacks could be overcome only by considerable investments. On the other hand, the historical roots of large-scale capitalist farming were less firm in the Great Plain than in Transdanubia. Here, small peasant farms, deficient in funds, had predominated even before the land reform. The inflexible, dogmatic and centralized bu- 
reaucratic policy of the $1950 \mathrm{~s}$ disregarded the regional differences due to local conditions. Thus the peasant policy of that time could not harmonize the individual interests of the peasants with the interests of society as a whole. It was in the tanya areas particularly that the bureaucratic methods of collectivization had grave consequences.

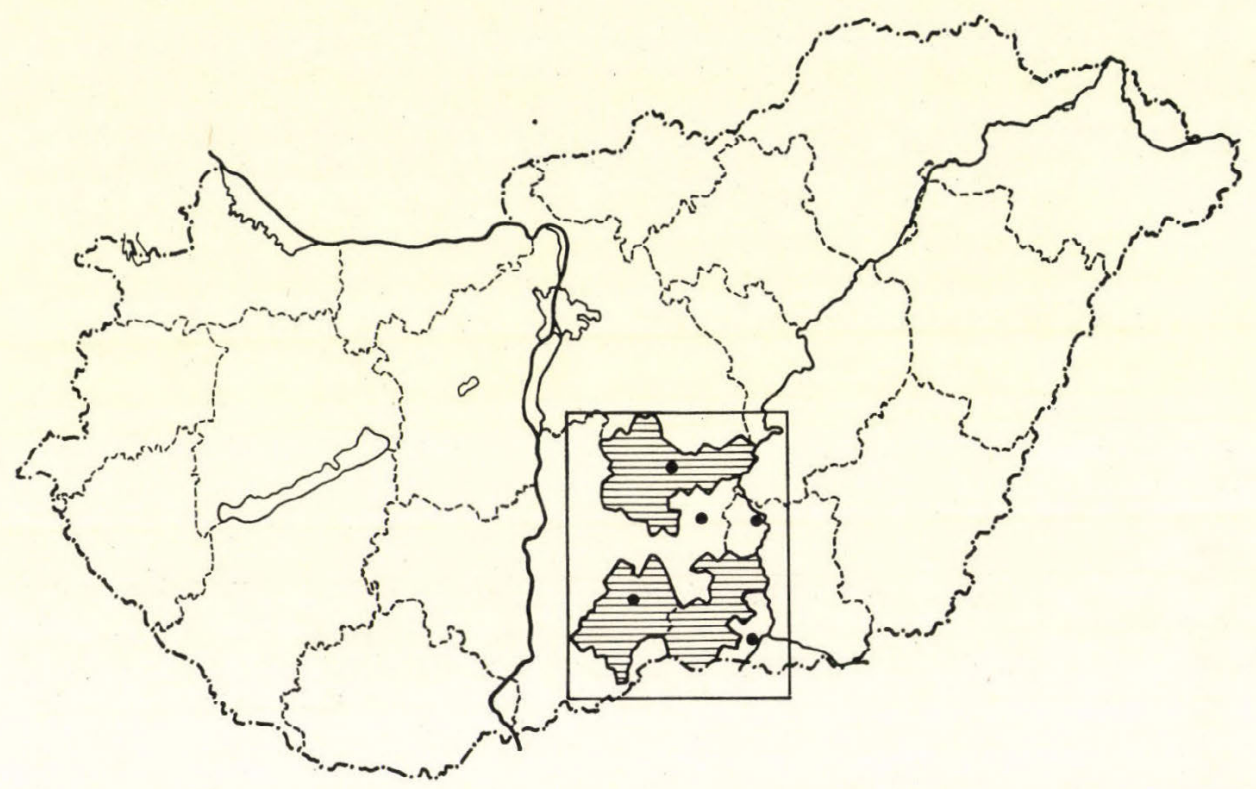

Fig. 4. The Danube-Tisza Interfluve study area

One of the most problematical areas with regard to the collectivization of agriculture has been the sandy region between the Danube and Tisza rivers where tanya settlement is dense. This area has the largest share in tanya inhabitants who account for more than two-thirds of its population. For this reason it has been chosen by the author as a model region for demonstrating present-day tanya problems (Fig. 4).

This area of $350,000 \mathrm{~km}^{2}$ comprises much of the undulating, poorly drained and wind-blown sand surface of the Danube-Tisza Interfluve and is dotted with saline lakes. It is little more than half a century since the mobile windblown sands were fixed by the adaptation of vine and fruit cultures to sandy soils, through the efforts of the agricultural population of the towns of Kecskemét, Kiskunhalas and Szeged whose administrative boundaries covered large, non-urban areas. In this way the sandy soil, which was formerly deserted, has been transformed into a vast vineyard, orchard and vegetable-growing region. Such production was labour-intensive and was closely connected with the tanya farming and settlement system. As a result, the former puszta has 

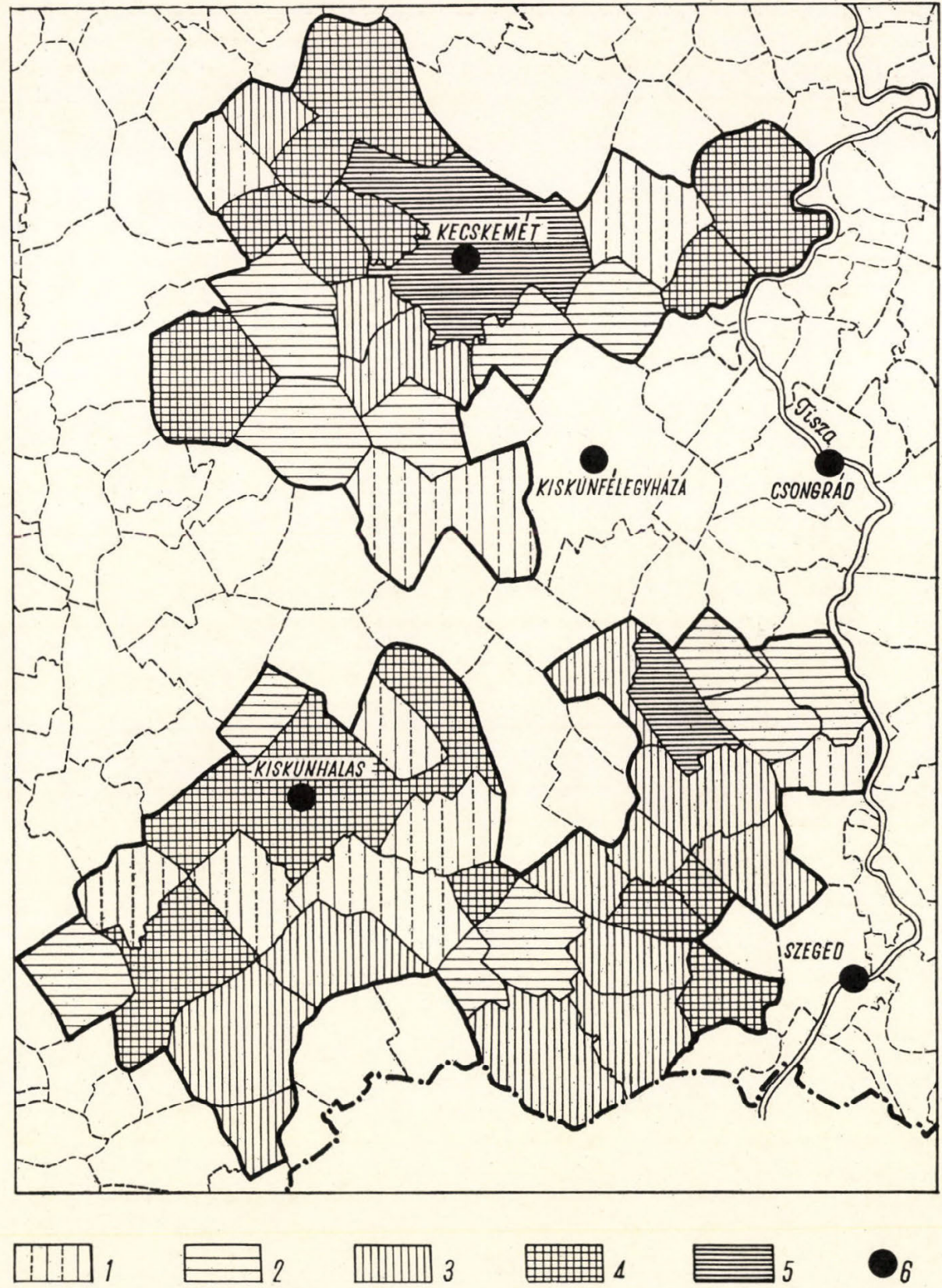

Fig. 5. Density of population 1960 (person per $\mathrm{km}^{2}$ ). $1=1-35 ; 2=35-50 ; 3=50-75$; $4=75-100 ; 5=100-300 ; 6=$ town. (For the towns, the data are to be interpreted without the population in the closed, built-in areas) 

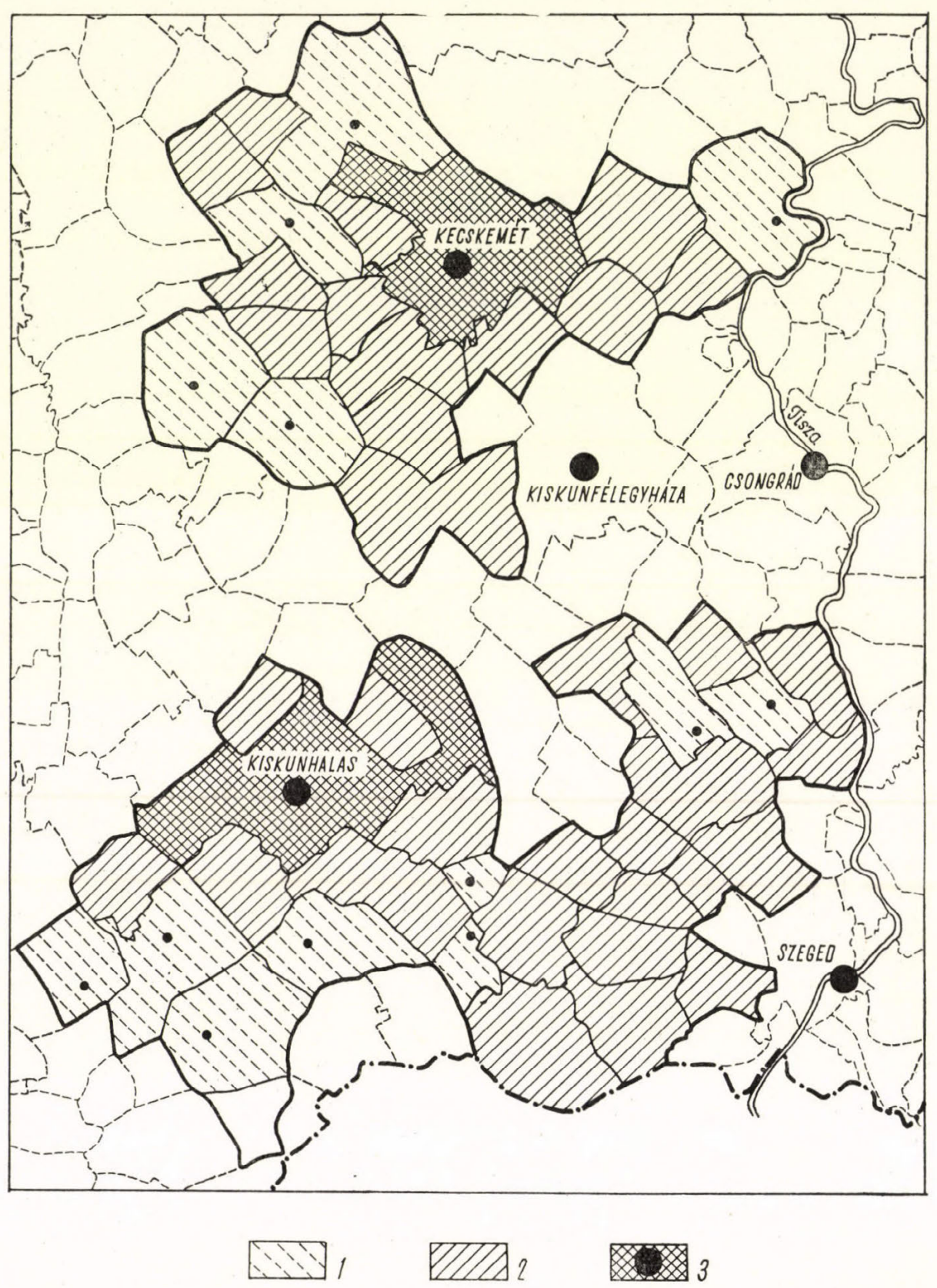

Fig. 6. Structure of the settlement network. 1. Early tanya community with a villagelike nucleus. 2 . Recent tanya community, scattered settlement. 3 . Town with tanya-dotted outskirts 

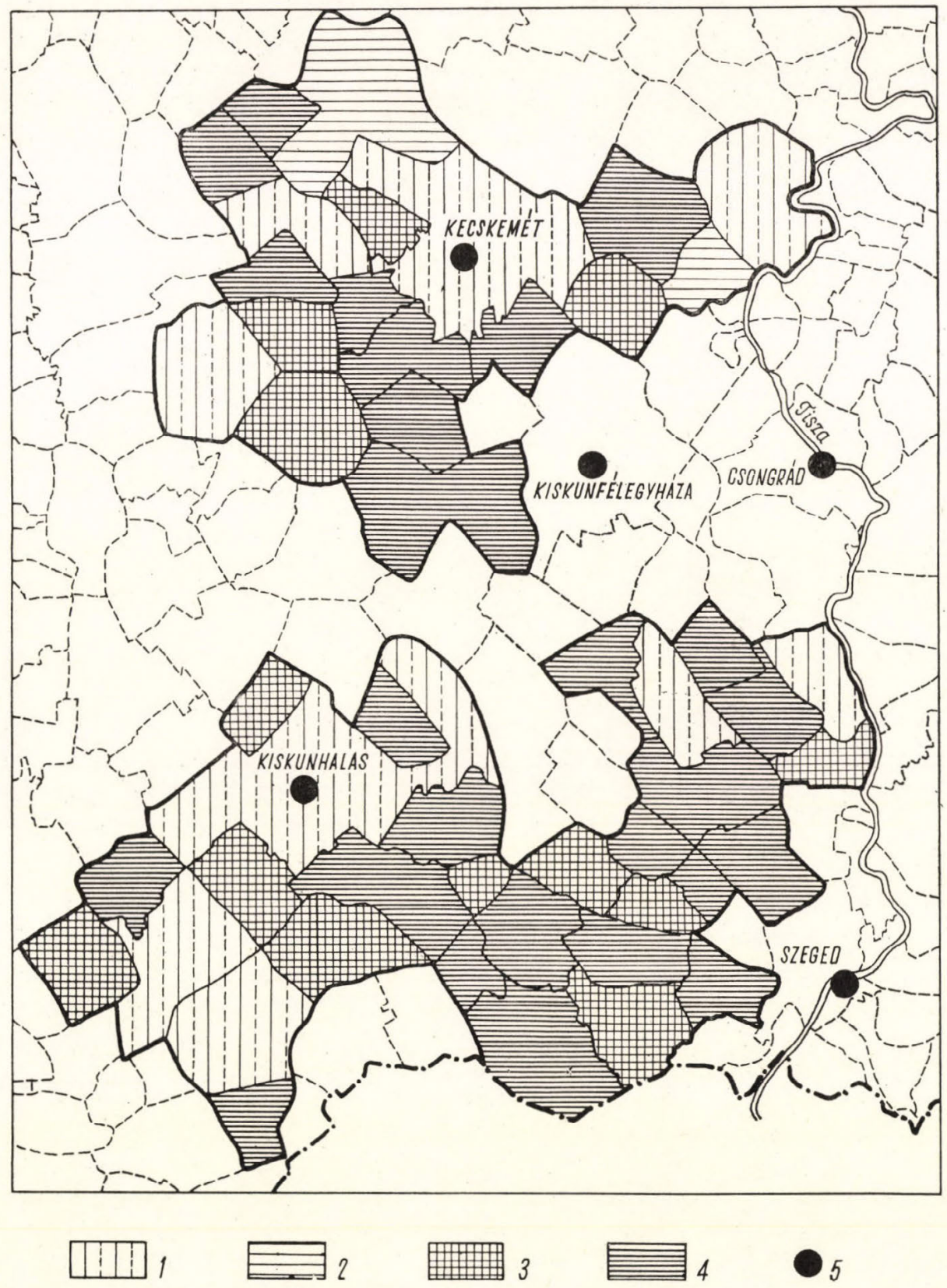

Fig. 7. Percentage ratio of tanya-dwellers by communities, 1960. $1=1-50 ; 2=50-65$; $3=65-80 ; 4=80-100 ; 5=$ town centre 
become the most densely populated agricultural area of the country with between 75 and 100 persons per square kilometer (Fig. 5).

Dessert grapes and fruits-particularly the famous Kecskemét apricotswere grown on tanya-plots averaging between 3 and 5 hectares. They were marketed in the near-by town, and were exported for the most part. In this newly populated region the ties between the tanyas and the parent settlement were closer than in those parts of the Great Plain where the tanyas had been formed earlier. Minor embryonic agglomerations began to appear in areas too distant from the nearest town for it to be reached by a return cart trip in one day. These tiny embryonic hamlets were nuclei of a village network and were also surrounded by a dense tanya network (Fig. 6). Most of them gained administrative independence as early as the $1930 \mathrm{~s}$, but over much of the area, which administratively belonged to the towns of Kecskemét, Kiskunhalas and Szeged until 1950, no embryonic hamlets could develop.

In 1948 the dense tanya-populated outskirts of these Great Plain towns were administratively separated from the urban areas, and independent tanya communities were created. The purpose of this measure was to accelerate and assist the elimination of the tanya settlement pattern and to create favourable administrative conditions for the development of a closed village system in the areas of dense tanya population. A great number of new communities with artificially drawn municipal boundaries were thus formed.

A special tanya centre was set up to promote the resettlement of the tanyapopulation in nucleated settlements which were to be built at selected centres within the tanya community. For this end, measures taken included the preparation of settlement plans, the allocation of housing plots and support for house construction, etc. at the tanya centres. Public establishments such as schools, surgeries, and council-houses were built at places selected as tanya centres, while permission for the construction of new dwelling houses was only issued for these selected places. Housing construction outside these centres is prohibited even today.

Despite the above measures, hardly any progress has been made in resettling the population of the tanya communities, and no viable agglomeration has been formed as yet. Thirty-six out of the eighty-four communities in the area being considered, contain only scattered settlements and are lacking any nuclei, while the 12 villages lying 20 to $30 \mathrm{~km}$ away from the town which do exist started to develop before 1930 (Fig. 7).

The average size of the tanya communities in the area being considered is 4 to 6,000 hectares, and their population varies between 3,000 and 6,000 persons. The ratio of vineyards and orchards to the total cultivated area exceeds 25 to 30 per cent in most of the communities. The largely labour-intensive form of land utilization and the high density of population are closely interrelated. Grape and fruit production on small farms requires constant care, skilled cultivation, and cannot dispense with a close connection between place of work and place of residence. Hence, the farmer cannot live far away from his land. Accordingly, the most economical and effective solution is provided by the tanya. Consequently, small-scale garden culture, on the one hand, and the tanya system of farming and settlement, on the other, are interdependent and inseparable from one another. This means that the economic reason for 
existence of the tanya system of settlement in this region must be accepted until the small-scale garden culture is replaced by more competitive largescale production.

Factors promoting the early introduction of large-scale production and types of farm being studied with a view to such developments are discussed below.

The two main types of current socialist farms are: (1) state-owned farms and (2) agricultural co-operatives. It is the latter type that predominates both nationally and in the area being considered.

The only state-run farm in our area is the "Helvécia" State Farm. Much of its agricultural land lies 10 to $15 \mathrm{~km}$ south of Kecskemét and extends over a number of adjacent tanya communities. Its predecessor was a large vinegrowing and processing farm founded with Swiss capital (hence its presentday name) in the $1930 \mathrm{~s}$, which, after nationalization, was greatly increased in area. Government-subvented, large-scale investment has enhanced the improvement of the farm. Extensive new orchards have been planted, and an irrigation system for tempering the continental climate and ensuring high standard yields has been developed. The consolidated area (Blockflursystem) of the farm has been turned into large fields. To ensure a permanent staff of farm workers, the farm administration has procured government-subvented housing for its employees at the place selected for the tanya centre. Most of the inhabitants of the neighbouring tanyas work on this state-run farm. Their resettlement in the tanya centre is being encouraged by various kinds of inducements. In recent years the farm has provided its workers with a steady source of income, roughly the same as that of an industrial worker. Voluntary resettlement of people from the tanyas to the housing estate, the nucleus of a future agglomeration, is rather a slow process which is hoped to gain momentum. Still not solved is the problem of the tanyas whose residents are either members of co-operatives or are independent farmers. For economic reasons, these people see no advantage in moving to the village and leaving the tanyas surrounded by their vineyards or orchards which is their livelihood. They are therefore rather unwilling to change residence.

Two-thirds of our study area belong to socialist collective fams, the agricultural co-operatives. Since the period of mass collectivization between 1959 and 1962, the percentage of private farmers has become insignificant.

The tanya plots of the co-operative members, which is their dwelling house and an average of 1,000 négyszögöl * of land around it-are privately owned. This land as well as the adjacent "household plot" of 1,000 to 1,6000 négy-

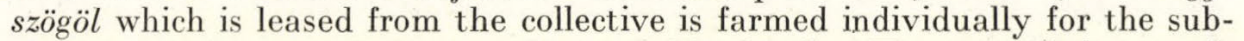
sistence of the cooperative member and his family. The rest of the area is farmed collectively. The proprietory rights concerning this land belong to the individual co-operative members, although the land itself is owned by the co-operative as a whole. In tanya areas the consolidation of collectively farmed land into large contiguous fields is rather difficult, as the area of the collective farms is made up of thousands of privately owned and farmed tanya lands.

\footnotetext{
* Négyszögöl is a Hungarian measure of area. 1 négyszögöl is equal to 3.57 sq. m,.
} 
On the Sand Ridge of the Danube-Tisza Interfluve the co-operatives are mostly new farms, and are between 5 and 7 years old. So far they have merely managed to achieve the organizational framework of large-scale agricultural production. Following after this must come measures to ensure large-scale production in all respects. The development of the collective farms is supported by many forms of assistance, such as long-term credits, new machines and installations, etc. given by the government.

The role of the tanyas in the current production activities of the agricultural co-operatives is as follows. First a distinction should be made between cooperatives specializing in vine and fruit production, and co-operatives dealing with field-crop production and associated stockbreeding. In the co-operatives producing field crop the importance attached to the working-place function of the tanyas is gradually declining. This is the case with the co-operatives farming on the fertile loessic and flood-deposited soils on our east and west borders. To replace the multitude of scattered tanya farm buildings now out of use, the co-operative farms are constructing large collective stables, granaries, crop-processing plants, etc. The extent of such developments may differ from farm to farm and from area to area. Where these collective farm buildings are still lacking, the farm-yards of the tanyas are used for housing livestock and storing crop produce, until the new farm buildings are constructed. The decay of the tanya system here has already begun and is progressing rapidly.

The situation is different in the vine-and fruit-producing co-operatives, where the development of large-scale production is a very complex and longterm task. This programme is to be carried out progressively without disturbing existing small-scale production which supply export markets to a large extent. For this reason, the organization of the fruit- and wine-porducing cooperatives is somewhat different from those producing field crops. Most of the co-operative members are small holders who cultivate 3 to 6 hectares and market their produce individually. They give part of their income, however, to a common fund devoted to the progressive development of large-scale wine and fruit production, the amount being usually proportional to the size of their holding. "Shareholders", or members, of the large farm to be developed will be the members of the present-day wine-and fruit-producing co-operatives.

Farmed individually, particular small plantations (gardens) of high yield can provide a living for a 5-member family, but they require full-time work from all members of the family. As well as providing a good income, this labour-intensive form of land utilization stabilizes the dense tanya network of the landscape, as it is closely interconnected with the tanya system of farming and settlement. Hence, a long survival of the tanya system can be expected in such areas.

The tanya as a dwelling place and as a way of life is out of date, with little scope for improvement. The level of public utilities is very low, as such developments are uneconomical. Electricity has been installed in about a third of the tanyas after 1945. Water is drawn from shaft wells. As regards primary functional units and public establishments, marked progress has been made since the formation of the tanya communities; consequently primary schools, surgeries (consultation rooms), local government organizations, etc. are within 

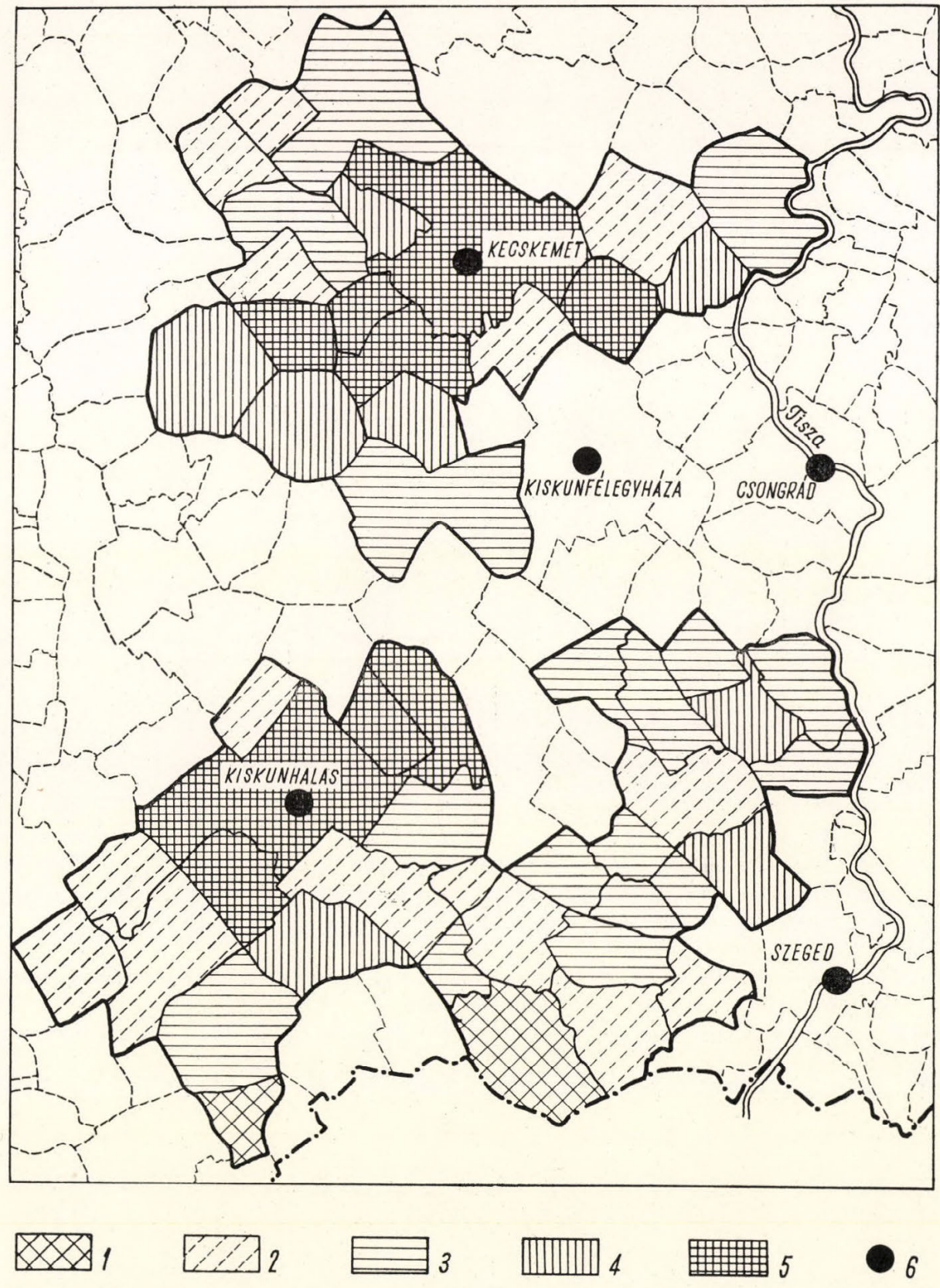

Fig. 8. Population change in per cent between 1949 and 1960. $1=$ decrease $15-50 ; 2=$ decrease $5-15 ; 3=$ decrease $0-5 ; 4=$ increase $0-5 ; 5=$ increase $5-25 ; 6=$ town centre 


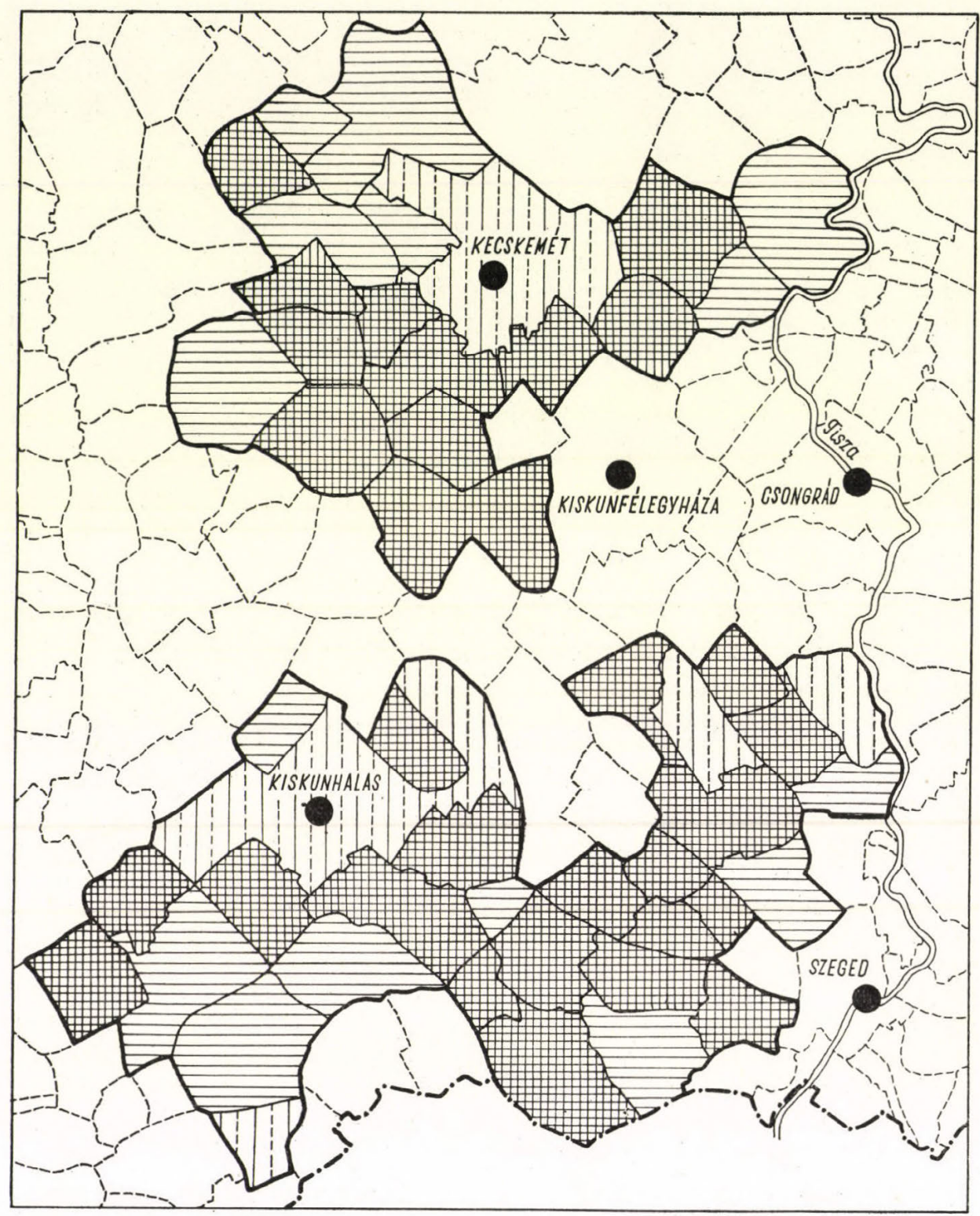

\section{ए门1}

Fig. 9. Percentage of agrarian population, 1960. $1=1-60,2=60-80,3=80-100$, $4=$ town centre 


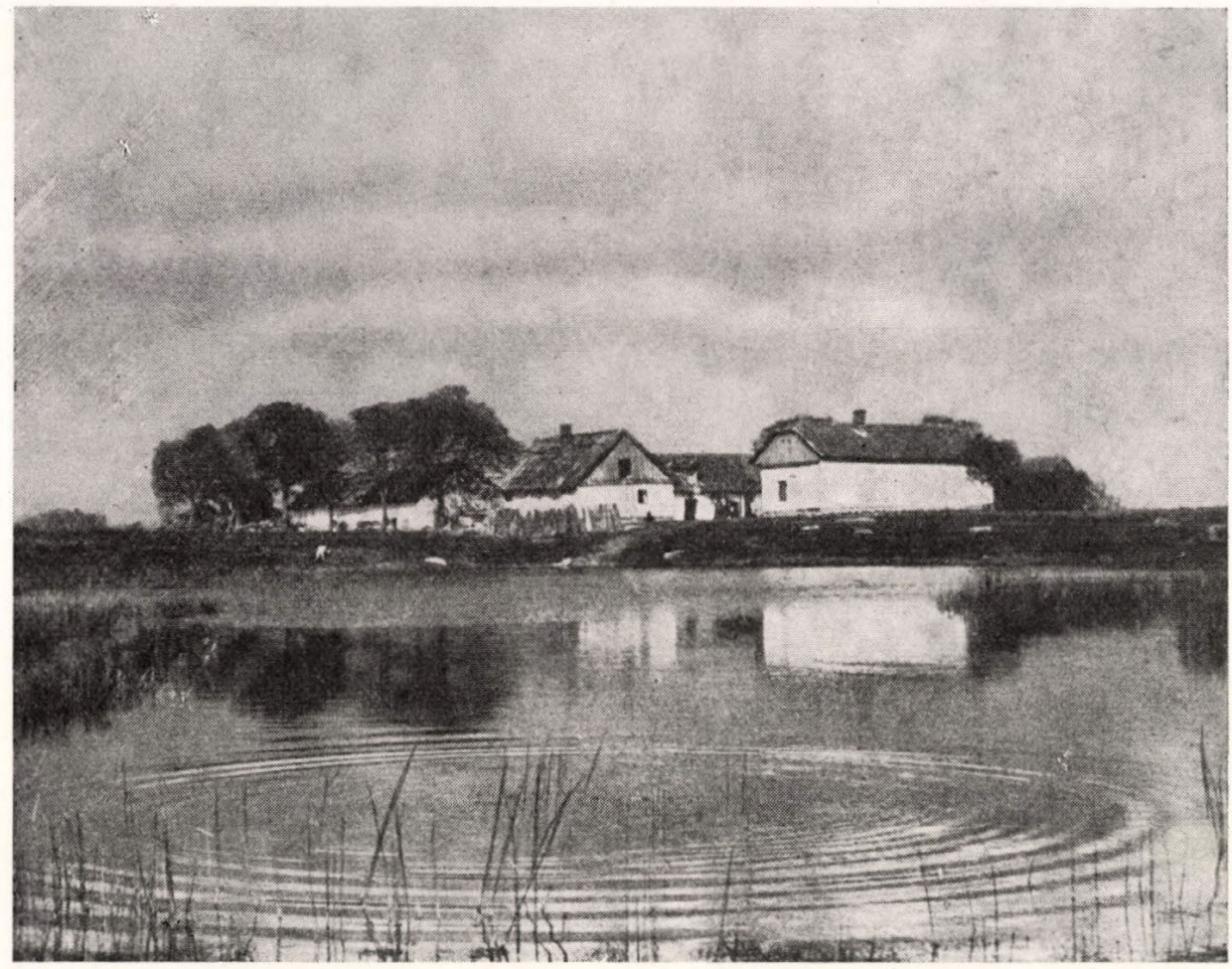

Fig. 10. Unfenced isolated tanya in the Great Hungarian Plain

a 1/2- to 1-hour walk from most of the tanyas. Access to higher-order public establishments in the town is provided by good communication facilities, particularly by regular bus services. These conditions, however, are far from satisfactory as yet, owing to the rapid growth in requirements.

Having but few ties with current technical and cultural developments, the tanya dwelling places have become outmoded. Although the advantages of income provided by the fruit- and wine-producing co-operatives still keep some members clinging to their tanya homes, this loyalty is largely restricted to the older generation. The younger generation is rapidly moving to the towns, seeking non-agrarian employment there, while in the field crop areas the middle-age groups have also been involved in this out-migration.

On the national average, between 1949 and 1960, the number of tanyadwellers had dropped to nearly a half of the maximum figure. The population in 48 communities declined, that is nearly 50 per cent of the settlements in our study area, but 23 communities were not affected by the process until after 1949 (Fig. 8). The rate of decrease of 8 to 12 per cent, however, was still very low, and out-migration markedly exceeding natural growth was observed in 5 communities only. On the other hand, 50 per cent of the communities of our area had a low rate of population increase, but most of these communities 


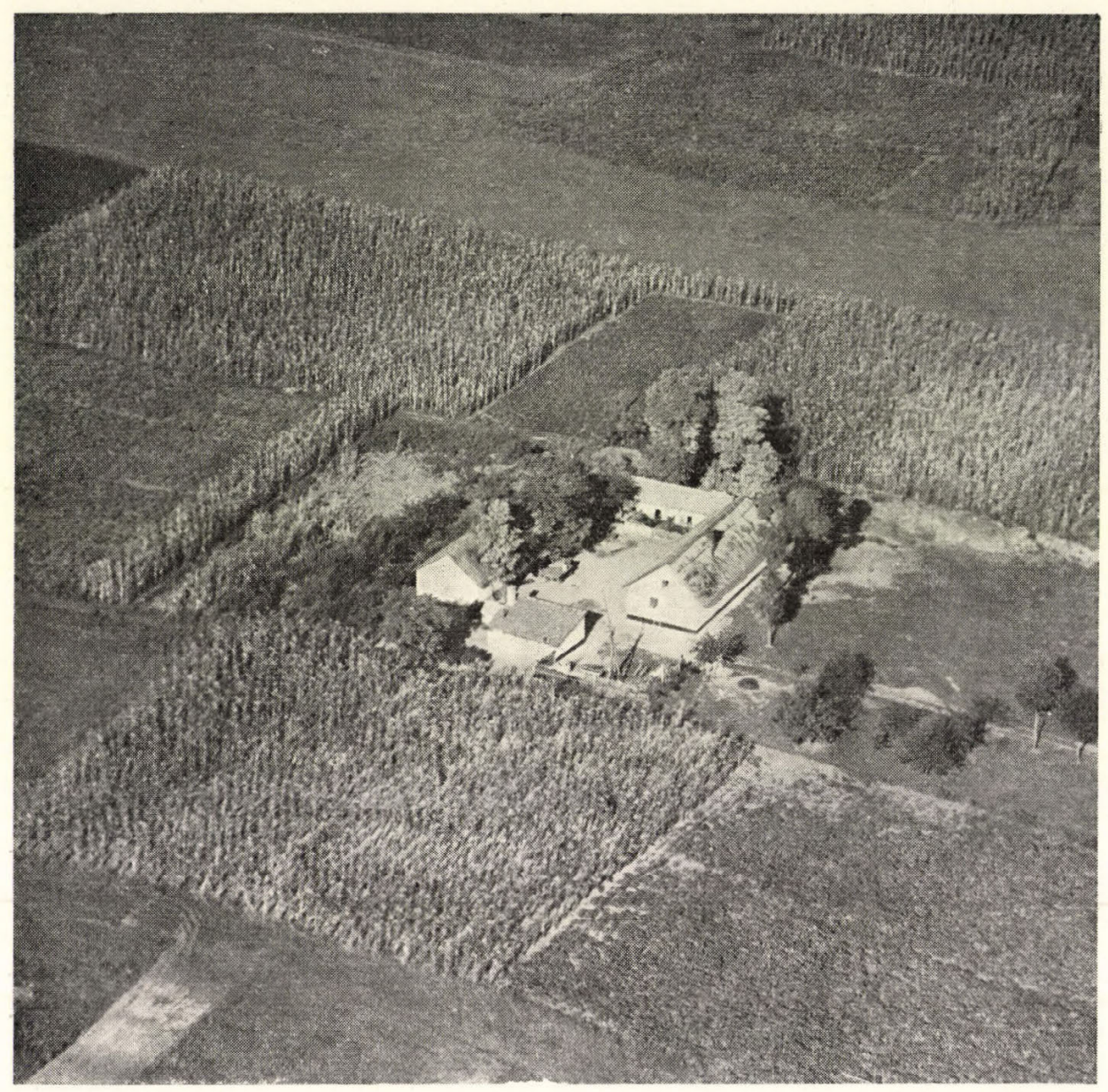

Fig. 11. A tanya amidst cultivated vineyards in the Danube-Tisza Interfluve.

have good access to communication facilities, which makes it possible for the younger generation to commute to and from industrial and other nonagrarian working places in the towns.

The communities of our area are poor in industry. Industrial enterprises of importance only occur in the towns of Kecskemét, Szeged, and Kiskunhalas. Their attraction to labour is felt in those communities which have good communications with them. The process of commuting, however, is soon followed by permanent resettlement in the town. In the majority of the tanya communities, however, the ratio of agricultural earners is still higher than 75 to 80 per cent (Fig. 9).

Out-migration is coupled with the progressive aging of the agricultural population which is characteristic of the entire area, and only local differences 


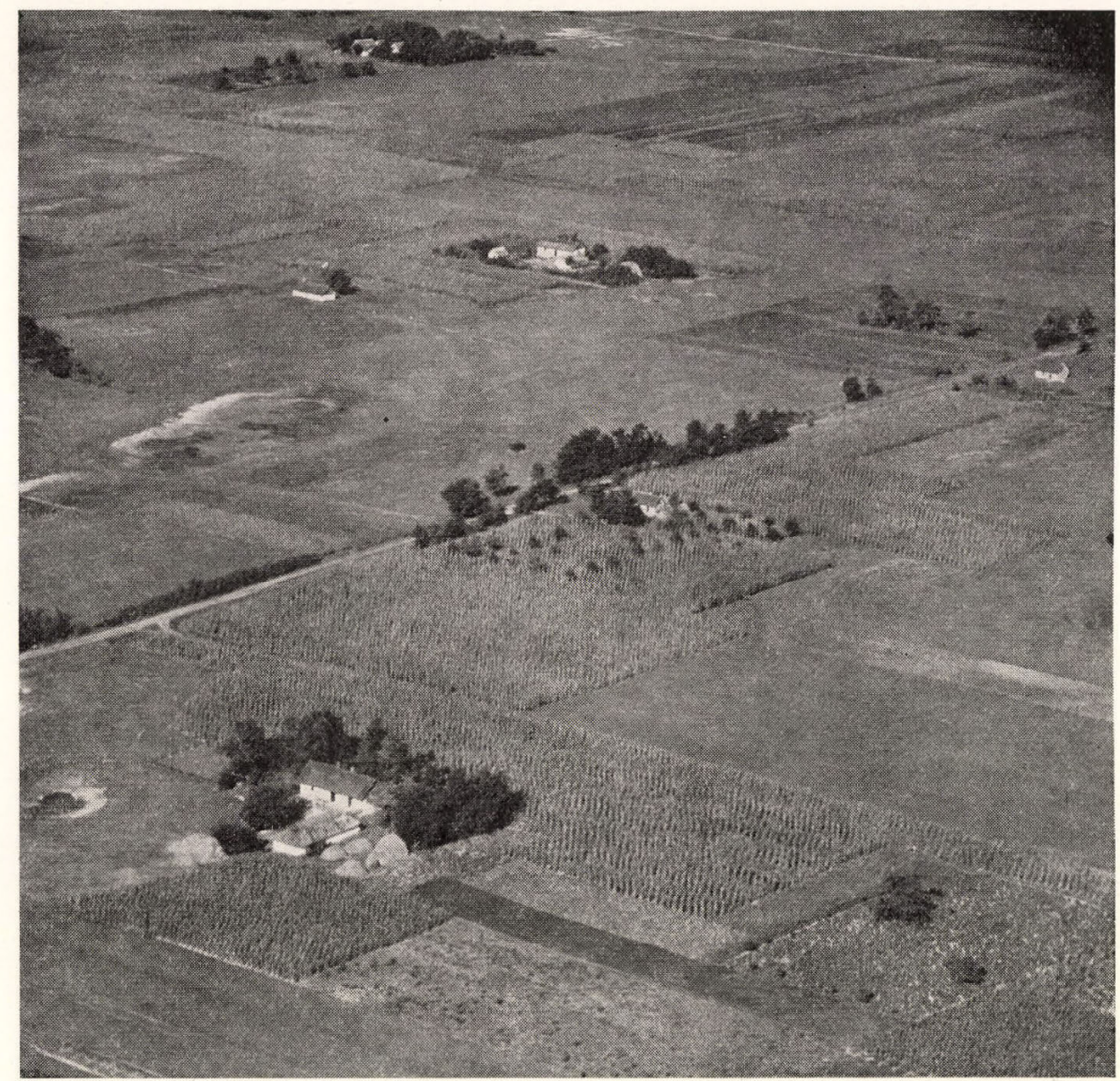

Fig. 12. Dense tanya net around Kecskemét

in the rate of this process exist. On the average, 13 to 16 per cent of the tanya population of the area is over sixty, and in 3 communities this figure is between 19 and 21 per cent. Yet despite ageing and out-migration, the presentday tanya system will probably survive for another 15 to 20 years even in the most out-of-date ficld crop areas, while the wine- and fruit-producing tanyas would seem to have an even longer future ahead of them. Settlement policy should seek harmony between settlement type and the system of production as the latter takes a definite form. One of the ways of achieving this is to concentrate the tanya population into village-like agglomerations. The resettlement of the tanya population in towns-one of the earlier versions of recommended settlement policy-seems neither feasible nor reasonable. This is because, on the one hand, a town cannot absorb so many agricultural work- 
ers and, on the other hand, because place of work and place of residence are so closely interconnected that a departure like this would be prohibitive. Current settlement policy is to promote, by all possible means, the elimination of the tanya system and the formation of village-like agglomerations. At the same time, it endeavours to adjust itself to local production interests, by taking into consideration the different roles the tanyas may play in the sphere of production in different areas. Some tanya functions may thus eventually survive for a long time to come.

\section{REFERENCES}

Belényesi, M. (1938): Adatok a tanyakialakulás kérdéseihez (On the development of the "tanya" system). Népességtud. Intézet, Budapest.

Erdei, F. (1933): A makói tanyarendszer (The Makó "tanya” system). Szeged: Városi nyomda. Erdei, F.: Magyar falu (The Hungarian village). Budapest: Athenaeum.

Erdei, F. (1957): Futóhomok (Wind-blown sand) Budapest: Gondolat Kiadó (3rd ed.).

Györffy, I. (1910): A nagykún tanya (The "tanya"' of the Nagykúnság). Néprajzi Értesíto, Vol. 11.

Győrffy, L. (1956): Adatok az Alföld törökkori településtörténetéhez (A contribution to the settlement history of the Great Hungarian Plain during the Turkish occupation). Kossuth Kiadó, Szolnok.

Központi Statisztikai Hivatal (1961): 1960. évi népszámlálás. Bács-Kiskun megye személyi és családi adatai (The 1960 census. Personal and family data for Bács-Kiskun County) Budapest: Statisztikai Kiadó V.

Központi Statisztikai Hivatal Bács-Kiskun megyei Igazgatósága (1962): Bács-Kiskun megye fontosabb statisztikai adatai (The more important statistical data of Bács-Kiskun County). Kecskemét: Statisztikai Kiadó V.

Központi Statisztikai Hivatal Bács-Kiskun megyei Igazgatósága (1963): Bács-Kiskun megye fontosabb statisztikai adatai (The more important statistical data of Bács-Kiskun County). Kecskemét: Statisztikai Kiadó V.'

Lettrich, E. (1968): Kecskemét és tanyavilága (Kecskemét and its surrounding "tanyas"). Földrajzi Tanulmányok No. 9. Budapest: Akadémiai Kiadó.

Mendöl, T. (1943): Die Stadt im Karpatenbecken. Zeitschrift der Ungarischen Geogr. Gesellschaft, Vol. LXXI, Nos 1-2.

Mendöl, T. (1963): Általános településföldrajz (General settlement geography). Budapest: Akadémiai Kiadó.

Simkó, Gy. (1910): Nyíregyháza és tanyáinak településföldrajza (The settlement geography of Nyiregyháza and its"tanya"s). Földr. Közl. 38.

Szabó, I. (1929): A debreceni tanyarendszer kialakulása (The development of the Debrecen "tanya" system). Föld és Ember, Vol. 9.

Szabó, I. (1960): Agrártörténeti tanulmainyok (Studies on the history of agriculture). Budapest: Akadémiai Kiadó. 


\section{THE COLLECTIVIZATION OF AGRICULTURE AND THE TANYA SYSTEM}

by

E. P E T R I

A settlement network is a continuously changing and evolving social phenomenon. Its variation is controlled by the evolution of society itself, a process which is constantly ahead of the evolution of the settlement network and poses new requirements for the settlement pattern, which creates disparities between it and social production. The magnitude of these disparities depends on the type and the rate of evolution in society, and can only be eliminated by meeting the requirements raised by society; through the modification of the settlement pattern.

The general regularity in the evolution of settlement patterns means that the disparities between the requirements of society on the one hand, and the existing settlement pattern on the other, are historically most distinct during qualitative changes in society, when one mode of production is being replaced by another. A settlement network produced by the old mode of production is unsuitable for meeting the new requirements, so it must be modified at a satisfactorily rapid rate.

After World War II, the capitalist forms of production have been gradually replaced by new, socialist, modes of production in Hungary. It is no accident that the development of the settlement network of Hungary cannot keep pace with the evolution of the society, since this corresponds to the basic law of the evolution of settlements, though in the past 20 years marked changes have taken place during the socialist construction of the country.

The transformation of the feudal and capitalist heritage in the settlement pattern does not require a complete reorganization, but it does demand the adaptation of the existing base to the new needs. The base is there, and it has only to be altered and fitted for the aspirations of the new society. In doing so, we have to retain all that is of value and reorganize the remainder.

Most problematic, and ripe for transformation are the following inherited elements of Hungary's settlement network:

1. In the town network, the spatial disproportions, the substandard condition of the provincial towns, and the undesirable predominance of the capital.

2. In the rural settlement network: (a) the hamlet pattern of settlement in the southwest, northeast and northern parts of the country and (b) the tanya system of settlement of the Great Hungarian Plain.

The objective of the present paper is to discuss the fundamental problems of the tanya system, in the context of the post-collectivization stage of the evolution of Hungarian agriculture.

In Hungarian statistics there is no special record of the population dwelling in the tanya. Only two population categories are distinguished, namely, people 
living within the municipal areas of the cities, towns, villages, and hamlets on the one hand, and the population living in their outskirts in farm areas dotted with isolated dwellings which are administered by the local authority in the near-by city or village, on the other. Although the latter are not all tanya residents, our knowledge of the main features of the settlement network

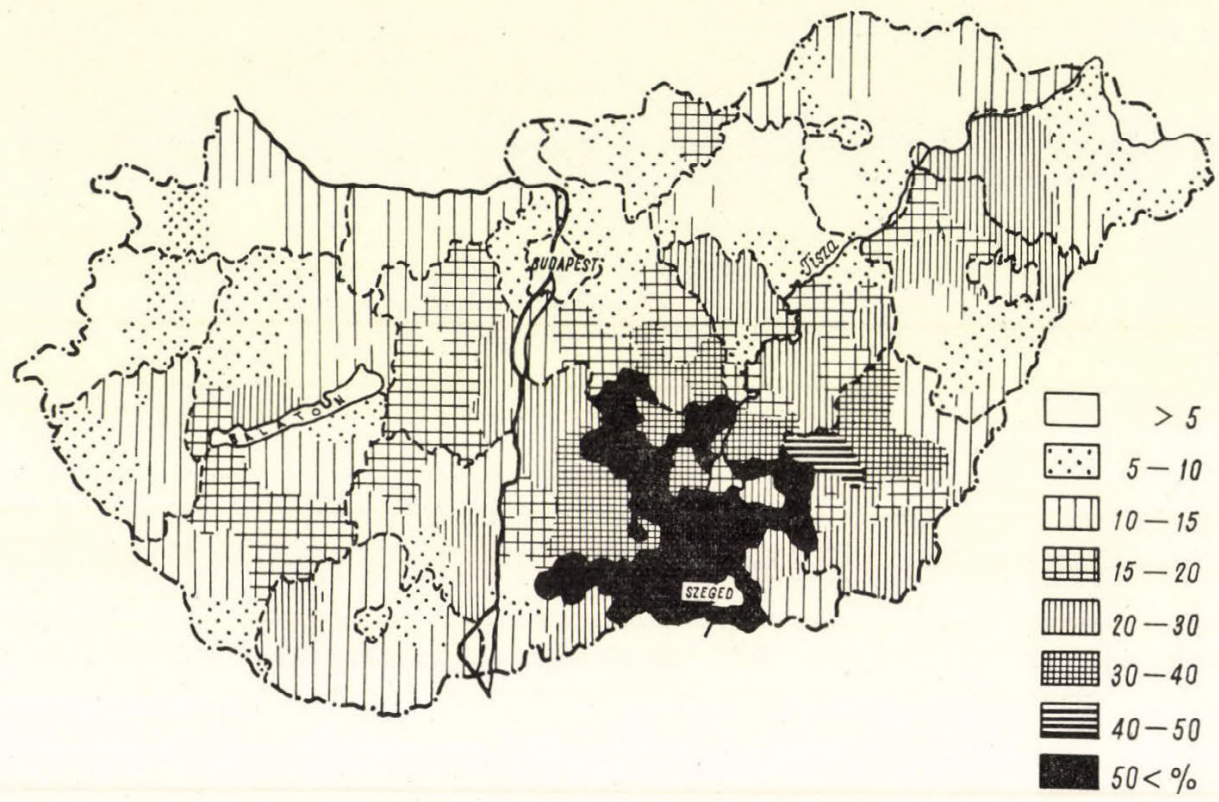

Fig. 1. Percentage of the population living in isolated dwellings, by municipal districts, 1960

allows us to extract information about the distribution of the tanya from the above figures. According to the 1960 census, $12 \cdot 2$ per cent of the population of Hungary, i.e. $1 \cdot 2$ millions, lived in these outer areas. Of these, an estimated 700,000 to 800,000 were tanya-dwellers, so that the actual number of tanyas can be estimated at about 200,000 .

The tanya settlement is distinct in the entire settlement system, and is characteristic of the Danube-Tisza Interfluse and of the Great Hungarian Plain east of the Tisza river (Fig. 1).

The appearance of the tanyas was associated with the formation of capitalist farms, a process which in the Great Plain coincided with the introduction of arable farming. To facilitate farming operations, the farmers began to build outhouses on their remote plots. Later dwelling houses were added to these buildings and were designed for periodical use. Their initial function was similar to the temporary shelters of the herdsmen, but they were soon turned into the permanent residences of younger productive members of the peasant families or of their hired farmhands. This process involved a qualita- 
tive change in the use of these plots and resulted in their becoming tanyas. During the period of capitalist development, with its striking social differentiation amongs the peasantry, the tanya system grew and soon gained predominance. By this time the tanya residents had no dwelling but the tanya house.

The existence of permanently inhabited buildings and the creation of a courtyard distinguished the tanyas from the other farmers' plots. Whereas the latter were simply cultivated by their owners, the tanya had the double function of being both the working and the dwelling place. The tanya then during the capitalist period included both the farmer's plot and his residence, the two being inseparable from each other. Hence, on the one hand, a tanya was a productive unit which collectively brought about the tanya system of farming. On the other hand, the tanyas, being settlements produced the tanya settlement pattern. The tanya farming system and the tanya settlement pattern were two inseparable aspects of the same phenomenon.

However, the tanya system was not the only form of farming based on private ownership. Throughout the cultivated area of a village, even in predominantly tanya-areas, the tanya and the isolated plot, whose cultivators went on living in the nearby village or town alternated in the landscape (Fig. 4/a). In other words, the tanya-farming system and settlement pattern did not lead to a disruption of the existing settlements. On the contrary, the population of the villages and of market-towns went on increasing, and new settlements were even established.

It is this fact that is responsible for the distinctive characteristics of the Hungarian tanya system, and which sets it aside from other well-known scattered settlement patterns. The evolution of scattered settlement patterns has most commonly occurred in two ways. (a) The existing settlements decayed almost completely, and only the nuclei of a few settlements were preserved as organizational centres for supplying the dispersed population. This process occurred for example in Great Britain, in the Scandinavian countries and along the Baltic Coast. (b) The population established a scattered settlement pattern initially and the minor central places with mainly trading functions appeared later when the life of the society required it, for example, the farmtype settlement pattern of the USA, Canada, etc.).

In the Great Hungarian Plain, however, there has always been a definite network of towns and villages of considerable size for the most part, even in the areas where the tanyas are most common. This is readily illustrated by Fig. 2, in which the town and village network of the southern part of the Great Hungarian Plain, where tanyas are most prevalent, is shown in terms of the percentage of the population living outside the municipal areas, according to the 1960 census. The percentages were: $35.9 \%$ for Bács-Kiskun county, $27 \cdot 9 \%$ for Csongrád county and $23.9 \%$ for Békés county, the counties appearing in the above order from left to right on the diagramme. Within this network, which is of medium density when compared with the rest of the World, the tanyas are a dominant feature of the settlement netsork. They are dispersed throughout agricultural areas, surrounding the villages and towns and separating them from one another. This point is illustrated in Figs. 3/a and $3 / \mathrm{b}$. 


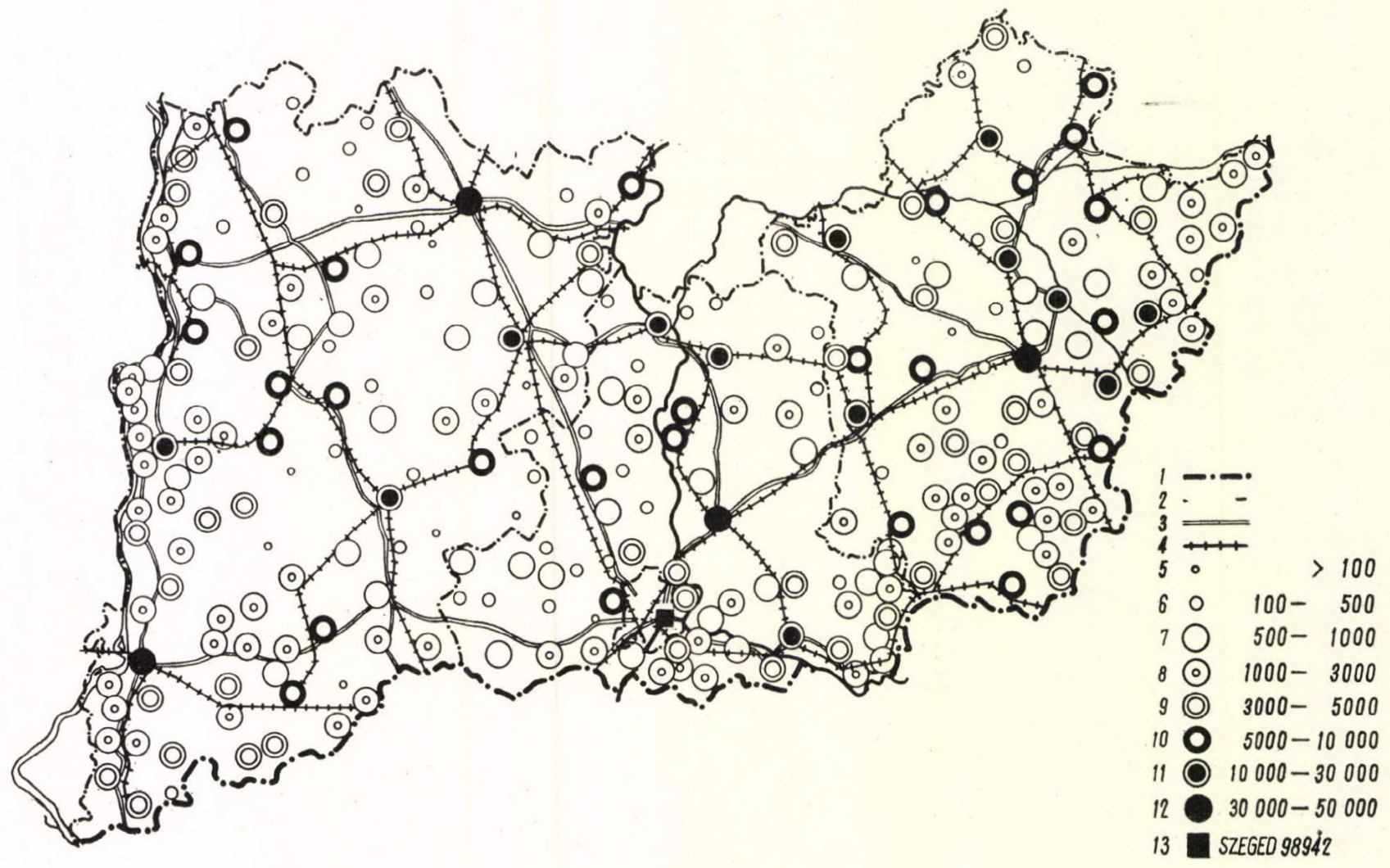

Fig. 2. Settlement network of the southern Great Plain, as reflected by the number of inhabitants. 1. Frontier. 2. County boundary. 3. Public road. 4. Railroad. 5-13. Settlements according to the number of inhabitants in the closed, built-in areas 


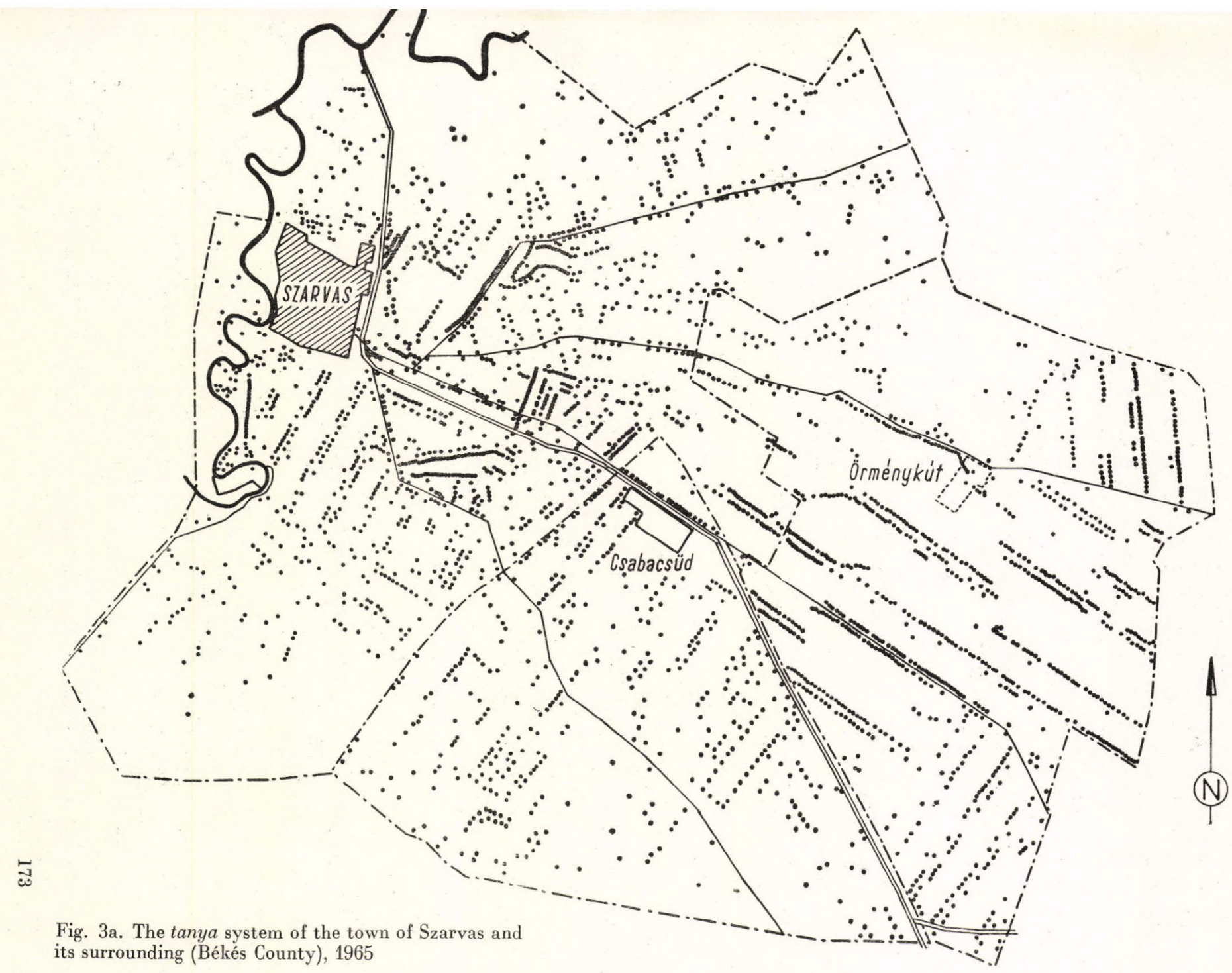




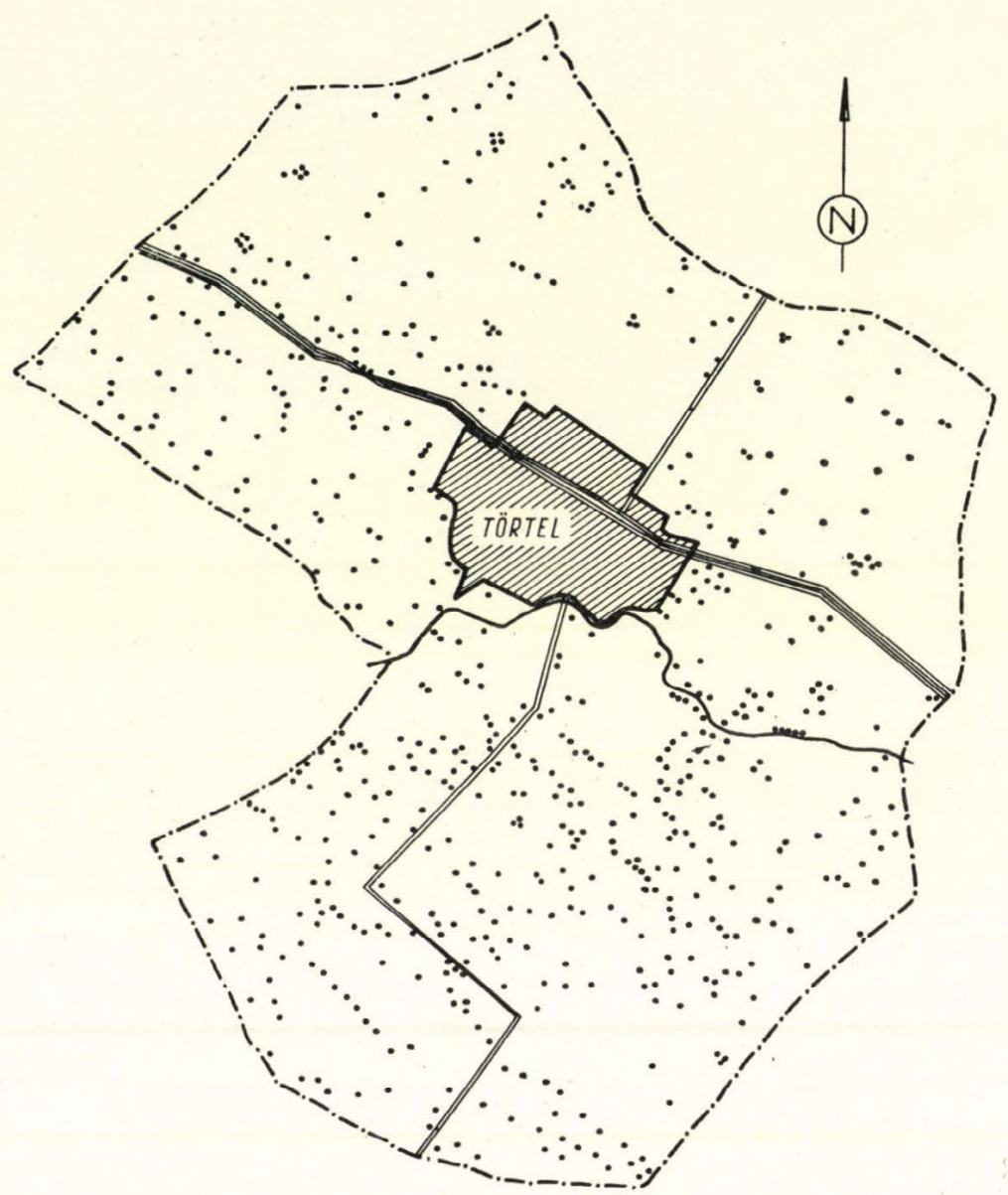

Fig. 3b. The tanya system of Törtel village (Pest County), 1966

The distribution pattern of the tanyas contains many forms. In the eastern half of Fig. 3/a, one of the most peculiar forms, the tanya-street type, which can be found hardly anywhere else in the country, is shown. Another special type is represented by the tanyas surrounding a physiographic feature, such as a minor lake or swamp. This type is also called "cluster-like disposition", and is wide-spread in the northeastern part of the Great Plain. The most common type of distribution pattern, however, is represented by the tanyas scattered randomly over vast expanses of farm land (Fig. 3/b). Most of the tanya areas of the Great Plain belong to this type.

For traditional reasons, we speak of tanyas and tanya-type settlement patterns even today, but the word tanya now conveys after the socialist reorganization of agriculture, a different meaning from what it did during the capital- 

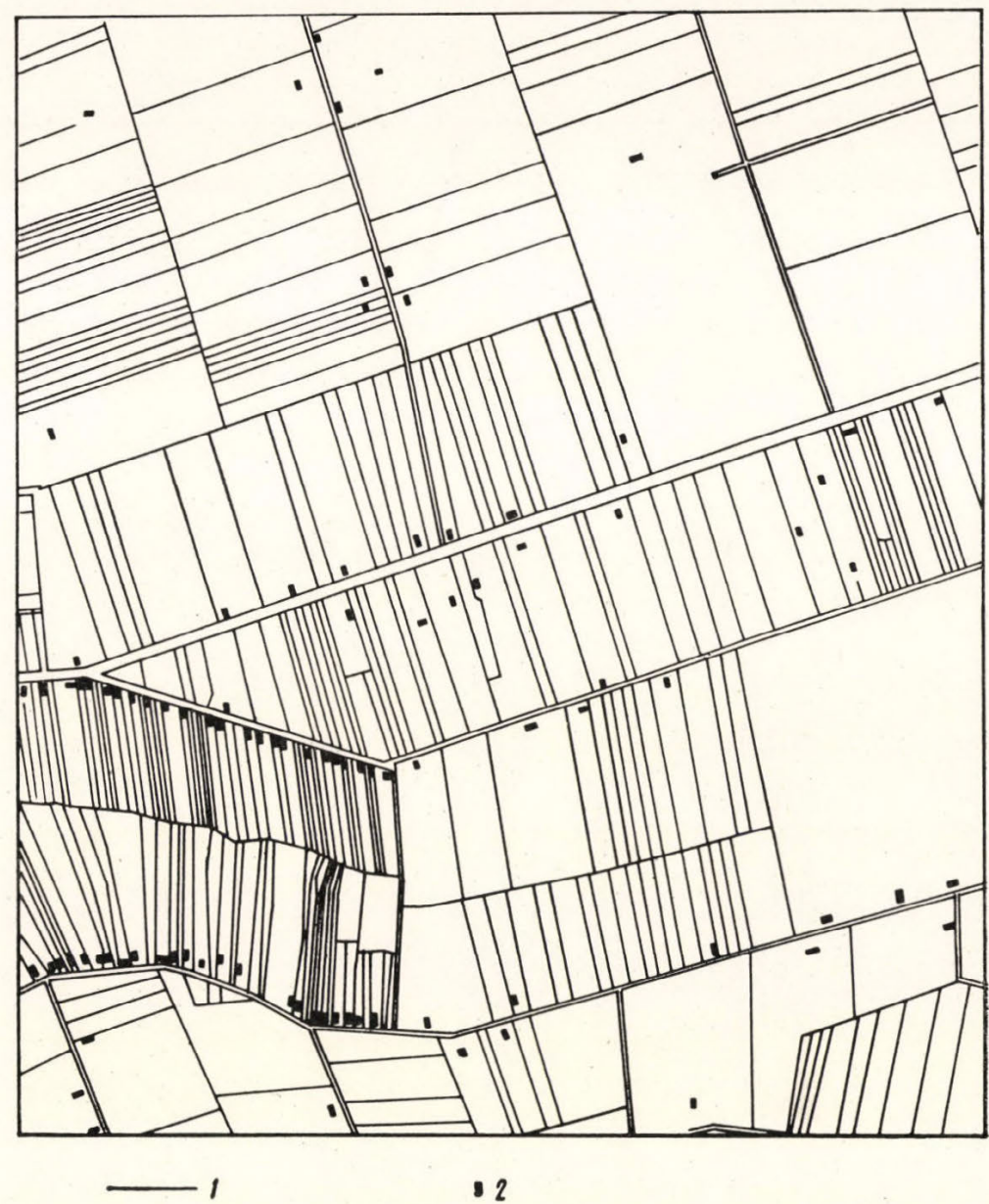

2

Fig. 4a. Distribution of holdings and tanyas in the outskirts of Szarvas, before 1945. 1. Boundary of holding. 2. Tanya dwelling

ist period. With collectivization, the cultivated area around the tanyas, except for the farm-yard and a plot of arable land up to 0.5 ha in area which was left untouched around the tanya-house, became part of the agricultural area of the large-scale socialist farms (Figs. 4/a and $4 / b$ ). This essentially abolished the agricultural function of the tanyas, although part-time cultivation of the household plots is still being carried on. Their dwelling function has remained, however, and the majority of the population living in tanyas are now employed on the large-scale farms, although a considerable number have found jobs in the non-agricultural sector of the economy. 


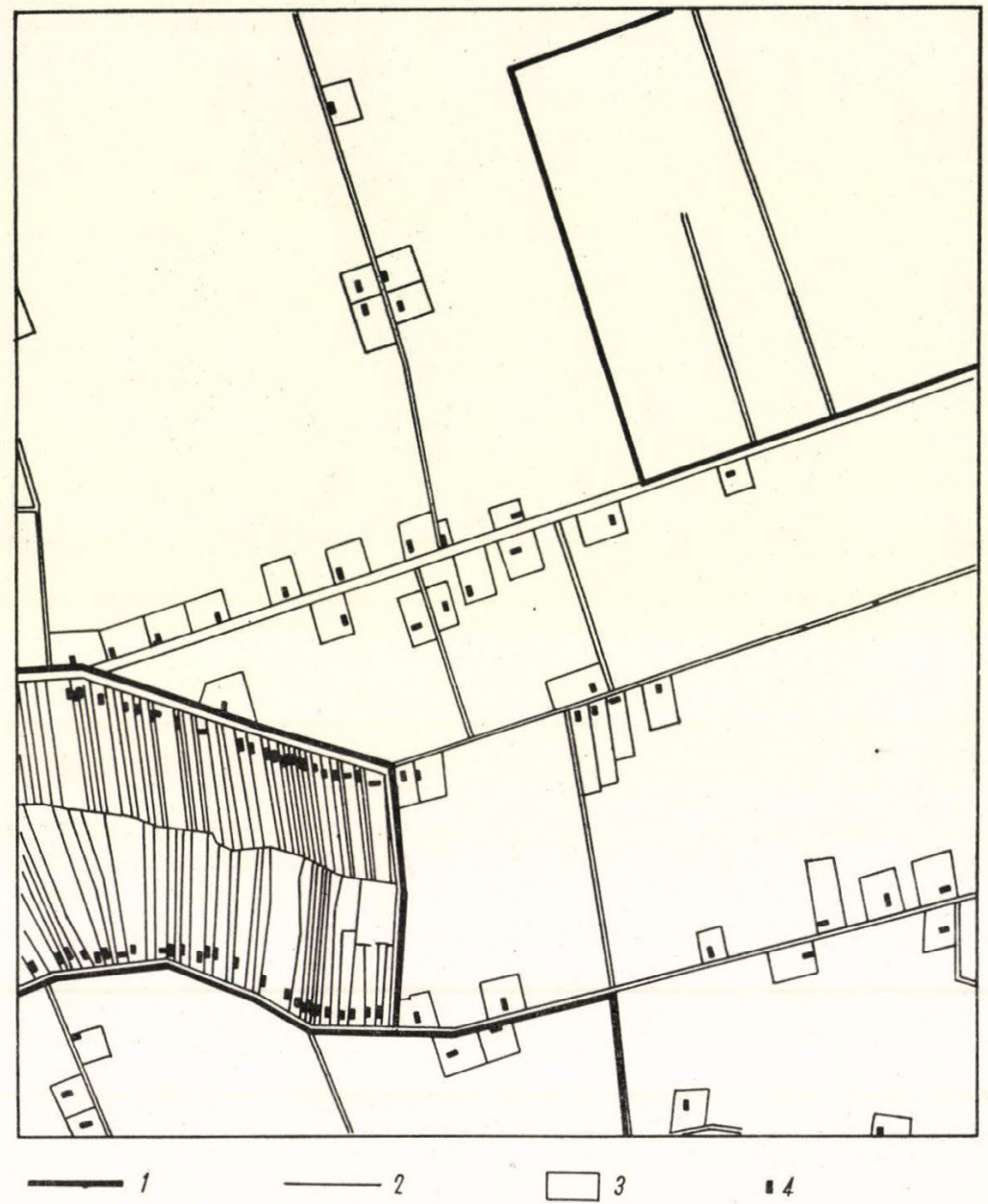

Fig. 4b. Distribution of holdings and tanyas on the outskirts of Szarvas, 1965 (area the same as in Fig. 4a). 1. Boundaries of socialist farms. 2. Boundaries of holdings in a non-collectivized area. 3. Boundary of tanya land. 4. Settlement

Thus we may conclude that, with the socialist reorganization of agriculture, the tanya-farming system has been dissolved in many places, but that the tanya settlement pattern has been preserved.

The living conditions of the population of scattered settlements are always worse than those of the inhabitants of cities and villages. This was equally, true during capitalism, and progressive scientists, notably sociologists, did not fail to notice it, presenting various suggestions for the abolition of the tanyas, which, however, were not feasible during the capitalist period, because the tanya settlement was an inseparable part of the small-scale system of 
peasant farming. Socialist agriculture, on the other hand, does not need the existence of a tanya system, and, in fact, the two are incompatible with each other.

Having solved the fundamental theoretical problems of socialist society and economy in the immediate post-Liberation period, it became clear that socialist agriculture would be organized on the basis of large-scale farming only, which would lead to the elimination of private holdings including the tanya farms. It was generally believed that the elimination of the tanyafarming system would do away with the raison d'être of the tanya settlement pattern and that, consequently, the tanyas would soon vanish. Even the specialists underestimated the amount of time involved in changing a historically developed settlement network and the fact that it lags behind socio-economic change. In practice, the theories have been contradicted and the tanya settlement pattern has remained, irrespective of a few minor quantitative changes, so that their number and distribution are much the same as they were at the time of the Liberation, two decades ago.

Steps were taken in the early 1940 s to promote the agglomeration of tanyas around certain nuclei, by creating what were officially called tanya-centres. These measures were ineffective, however, as were those taken between 1948 and 1954 with a view to administratively separating the tanya zones from the market-towns and large villages around which they were located, and accorded them the status of independent municipal areas. (As shown in Fig. 1 , in the areas of dense tanya-settlement there are minor tanya-free patches, which surround settlements deprived of their tanya hinterland.) For instance, after the separation of the tanya-zone around Szeged from that city, 14 per cent of the municipal area of the city and 75 per cent of its population, measured in terms of the 1949 census was retained. Out of the 35,000 ha separated from the city, 9 new administrative units were formed. As shown by the 1960 census, the percentage of the population living outside the municipal core of these new areas was less than 50 per cent in only one case, while it exceeded 90 per cent in five of the areas, indicating that not even the nucleus of a new settlement had been formed in these cases.

During the period of 1945-1965, 15 per cent of the tanyas were dissolved on average, this figure varying between 5 and 20 per cent, from area to area depending upon local conditions. Marked difference in the rate of tanya elimination occur which are correlated with different types of agricultural production. In vine, orchard and vegetable-growing areas the decrease in the number of tanyas is at a minimum, while the greatest decrease has occurred in areas of extensive agriculture. There are variations according to farming structure also. A greater number of the tanyas wedging into the area of staterun farms have been dissolved than of those situated in areas of co-operative farming. The rate of tanya elimination has been influenced by the communication facilities, i.e. the more remote tanyas are disappearing at a quicker rate, and by the spatial distribution pattern of the tanyas, i.e. residents of completely scattered tanyas are more inclined to preserve their tanya homes. Naturally, these general tendencies are markedly modified by local conditions.

Research has shown that within the last twenty years, tanya elimination was most marked between 1959 and 1963, the period of collectivization, when 
tanyas disappeared at an average annual rate of 2 to 3 per cent. During the last three years (1964 to 1966) the rate of tanya elimination has dropped to below 1 per cent a year, and has almost ceased in some areas. This clearly demonstrates that tanyas which have survived collectivization may well, in the long run, remain within the framework of socialist large-scale farming.

At the same time, there is no doubt that further progress will make the elimination of the tanya system unavoidable. To settle this problem, we have to find answers to the following two questions:

1. How fast should tanyas be eliminated in the future and how much time is necessary for their complete disappearance?

2. Where should the tanya residents be resettled?

These two questions pose the most crucial problems of tanya elimination which cannot be solved unless additional investigations are carried out.

The calculation of the time necessary for the elimination of the tanya system by simple mathematical techniques, on the basis of the average annual rates between 1959 and 1963, is unreliable. According to such calculations, the elimination of the whole tanya system would take an additional 3 to 4 decades, and there is no reason to accept this extreme pessimism which is as exaggerated as the optimism of those who, after the Liberation, advocated the rapid disappearance of the tanyas. An essential point ignored in simplified forecasts of this type is that the process of tanya liquidation is a part of the settlement evolution and as with all evolutionary processes, quantitative changes must be transformed into qualitative changes.

The point at which a qualitative change must set in during elimination of the tanyas is when their population has become too small for the economical maintenance of the existing level of services. The threashold value would appear to be a population of about half the original size, and with the disappearance of the service network which must occur for economic reasons when this population level is attained, the elimination of the tanyas will be greatly accelerated. On the basis of this, it is likely that the tanyas will disappear within 20 to 25 years and will not take an additional 10 to 15 years as suggested by the extrapolation of past rates of decrease.

The disappearance of the tanya is controlled by numerous factors, of which two groups can be distinguished. The first includes factors slowing down the process, and in the second, factors which cause its acceleration, while the rate of elimination at any given time is the resultant of the two. Virtually the whole of economic life, as well as of the non-productive spheres, embrace factors belonging to the two groups, the most important of which, in the tanya context, are listed below.

Agents retarding the process include the need of the national economy for the marketable produce of the household-plots in the initial stage of socialist agricultural development, and such goods are produced in greater amounts from the private tanya farms than from the household-plots in the villages or market-towns. From the point of view of the tanya population, this will also retard the process because of their insistence on obtaining surplus income from their tanya farms.

In addition, the rate of elimination is further slowed down by the shortage of housing in the prospective resettlement areas, since national economy is 
not yet able to meet the need for state-owned housing of low rent. Although considerable credits have been provided by the government for private housing developments, the individual still faces difficulties over the purchase of a plot of land for the construction of a house or of gaining possession of other types of dwelling in both towns and villages.

A further retarding factor is that the new socialist farms still lack the necessary transport facilities for carrying agricultural labourers living in towns and villages to and from their place of work. The employment of tanya residents does not require the existence of this facility, but the problem will become urgent, even for these people, as they move to the town.

Additionally, the government's limitations in meeting the requirements arising from the elimination of the tanyas would result in the problems of increasing the output of the building and building-materials industries and of meeting the communal and social needs arising from the resettlement of the tanya population in the municipal areas.

Last but not least, the tanya population tend to cling onto their traditional homes, especially the older generations, which also retards the elimination of these scattered settlements.

One of the main aims of a society building socialism is to continuously raise the living standards and the living conditions of the population. Improvements in these include the progressive elimination of the differences between the urban and rural population and to achieve this end, differences between the living conditions of the villagers and tanya-dwellers must be eradicated. Given the peculiar conditions of the country, however, these differences can only be eliminated, as shown above, by the progressive disappearance of the tanyas themselves. Since socialist agriculture, run on a large-scale, has no need for a scattered settlement pattern, the reorganization of agriculture along these lines is the most important factor promoting the elimination of the tanyas. The aspirations of the majority of tanya residents are in accordance with the aims of socialist society, and a rise in living conditions must stimulate the disappearance of these isolated settlements. The elimination of the tanyas is supported by the large socialist farms, because they inhibit land consolidation and because it is difficult to organize work among a scattered population.

A further important stimulus promoting the disappearance of the tanya is industrial development and the extension of communications, which, with the concurrent growth of service activities, demand more and more labour that is primarily met by employing people formerly part of the agricultural labour force. Although the tanya population is not entirely suitable for absorption into such occupations, it is apparent that once they have abandoned their agricultural job, they are more inclined to leave their tanya home, as long as they are presented with other residence.

It is apparent that, with further progress, the factors retarding the elimination of the tanyas will tend to decrease in importance, both in the private and national spheres of the economy, whereas agents accelerating the decline will tend to intensity. This will hasten their elimination even before the advent of the above-mentioned qualitative leap, and it is forecast that the tanya population will decrease by $50 \%$ over the next 15 years. The factors accelerating and retarding this process can be stimulated at any time through the 
appropriate measures, if, for some reason or other, the national economy warrants it.

The determination of the trends in resettlement, a geographical problem for the most part, is more difficult to approach. Under capitalist conditions this problem did not exist at all, since, if a peasant had abandoned his tanya, he merely changed his residence, while still working on the same agricultural property. For this reason, he moved to a village or a market-town that lay close to his place of work.

At the present time this is no longer the case. The general development of the country has stimulated wide-spread inter-territorial migration which will continue in the future. The growth of the industrial labour force and that in other productive and non-productive spheres is associated with a decrease in the agricultural population, including those living in tanyas. Since resettlement requires considerable investment at both the individual and national level, spontaneous changes in the settlement pattern during the elimination of the tanyas are not desirable, as spontaneity may lead to unwanted settlement distributions which at a later period could require expensive transformations.

The creation of small settlements with substandard living conditions should be avoided, which means that the new municipal areas created by the separation of the tanya zones from the central market-towns and large villages should be revised, before any further decisions are taken about their development. Care should also be taken to ensure that settlements, whose prime function is agricultural, are not required to absorb resettlers from the tanyas on a scale that will imbalance the long-term equilibrium between those seeking employment and the number of jobs available.

The choice of resettlement areas from among the existing villages, market towns and industrial cities, as well as the sites of new settlements to be built in the tanya regions, if any, should be based on long-term employment forecasts. In other words, when deciding on areas of resettlement, the decisions must be based on the long-term distribution of the forces of production in the country, which will allow prospective labour demand on the level of basic administrative units to be taken into account.

\section{REFERENCES}

Becsei, J. (1965): Békés funkcionális településföldrajza (Functional geography of settlement and population of the town of Békés). Földr. Ért. 4, Vol. 14.

Becsei, J. (1966): A tanyai település néhány kérdéséról (Some problems of “tanya” settlement). Földr. Ert. 3, Vol. 15.

Enyedi, G. (1964): A Délkelet-Alföld mezőgazdasági földrajza (Agreogeography of the southeast Great Plain), Budapest: Akadémiai Kiadó.

Erdei, F. (1942): Magyar tanyák (Hungarian "tanyas)". Budapest.

Erdei, F. (1951): A tanyarendszer kérdései a mezőgazdaság szocialista átszervezésével kapcsolatban (Problems of the "tanya" system related to the collectivization of agriculture). Hazai társadalmi és történettudományunk időszerü kérdései (Current Problems of Social and Historical Sciences in Hungary), Budapest.

Erdei, F. (1961): Az alföldi mezővárosok városfejlesztési problémái (Problems of urban development in the market-towns of the Great Hungarian Plain). Földr. Közl. 3, Vol. 9. 
Erdei, F. (1965): Történelmi lecke a tanyákról (A historical lesson about the "tanyas".) Kortárs 12.

Községeink föbb adatai 1960-1964 (Selected village statistics, 1960-1964). Idöszerü Statisztikai Közlemények, 1966, 1.

Major, J. (1962): A külterületi lakotthelyek vizsgálatának településhálózati vonatkozásai (The study of peripheral settlements and their relation to the settlement network). Településtud. Közl. 12.

Mendöl, T. (1928): Szarvas földrajza (The geography of Szarvas). Debrecen.

Mendöl, T. (1963): Általános településföldrajz (General settlement geography). Budapest: Tankönyvkiadó.

Perényi, J., Faragó, K. and Major, J. (1962): Mezögazdaság és településtervezés (Agriculture and settlement planning), Budapest: Közgazdasági és Jogi Könyvkiadó.

Petri, E. (1966): Szarvas és környéke tanyás településrendszerének mai települési problémáiról (Present-day settlement problems of the "tanya" system of Szarvas and its surrounding area). Földr. Ért. 3. Vol. 15.

Sárfalvi, B. (1965): A mezögazdasági népesség csökkenése Magyarországon (The decrease of agricultural population in Hungary). Budapest: Akadémiai Kiadó.

Központi Statisztikai Hivatal 1960. ési népszámlálási kötetei (Volumes of the 1960 census published by the Central Statistical Office). 



\section{A GEOGRAPHICAL STUDY OF STOCKBREEDING IN HUNGARY}

by

I. A S Z T A L OS

\section{INTRODUCTION}

In Hungary the role of agriculture in the Nation's economy is not just confined to supplying the internal population with food, since the share of agriculture in foreign trade is very significant. About one-fifth of total exports and about half of the exports bound for capitalist countries are made up of agricultural products.

An examination of the geographic distribution of agricultural production is important, because a scheduled distribution of production activities is required for Hungary's planned economy. That is why an exhaustive analysis of the existing agricultural regions and of the different sectors of production has been, and still is, necessary. As stated, with good reason, by T. Bernát and Gy. Enyedi, "the regional division of agricultural production is an important means for the controlled distribution of the productive forces of agriculture. A means of active interference, it widens the sphere of influence of the basic economic law of socialism, in order to enhance production by planned proportional development. The investigation of production areas includes, on the one hand, the determination of the current orientation and structure of production in the historical context and, on the other hand, a survey of the physical and economic conditions for agricultural production. Subsequently, the results of the two are collated and the areas most suitable for the production of particular crops and animal species are then selected" [5].

Although the geographic problems of stockbreeding have hitherto received little attention in Hungary, studies of this kind are nevertheless not unprecedented. Of these, the work "A szántóföldi termelés és állattenyésztés üzemi tájai” (Regions of field-crop production and stockbreeding) by Zoltán Magyary and Béla Reichenbach (1942) and the book "Magyarország mezo"gazdasági földrajza" (Agrogeography of Hungary) by László Görög (1954), are of particular interest. Research into production regions is dealt with in both books, though with a high degree of subjectivity due to the faulty methods applied. Stockbreeding plays a secondary role in these books, since preference is given to the examination of crop production. Yet the rich cartographic illustrations have been extremely valuable even for practical ends. Consequently, the need for an exhaustive examination of stockbreeding has become obvious, the more so, since the study of field-crop production and the publication of its result has been wide in scope and has resulted in the comprehensive work "A szántóföldi növénytermelés körzetei" (Regions of field-crop production) published in 1961 by T. Bernát and Gy. Enyedi.

Particularly in the first half of the nineteen fifties, agriculture was under a more or less centralized administration. The special conditions of individual 
areas, their most advantageous production possibilities and their specialization, if any, were disregarded and uniformity was forced upon the entire sphere of agricultural production. This economic policy not only jeopardized specialization in stockbreeding, but handicapped the developpment of livestock production as a whole. The peasons for these mistakes, included the lack of any survey of the regional distribution patterns of agricultural production, the misunderstanding of the interrelations between the different sectors, and of the non-appreciation of the regional differences in the Hungarian agriculture.

A remarkable contribution towards filling this gap has been provided by the book of Bernát and Enyedi (1961), although an assessment of the condition of stockbreeding has still not been made. Hence, the author's investigations have been focussed upon this subject (Asztalos 1963, 1964, 1965, 1966).

In his geographical study of stockbreeding the author has, first of all, aimed at finding out regional differences in livestock production, at distinguishing the areas of the individual animal breeds, and at developing a classification of regional types. Therefore, he had to analyse the density of the individual animal species, the ratio of breeders to total livestock, the composition of the livestock, the variation of gross production value, the market factor in stockbreeding, and the importance of livestock production within agriculture as a whole, etc.

The geographical study of stockbreeding without an assessment of regional differences in the feed-stuff balance, is not feasible. The creation of a sound feed-stuff basis and the coordination of stockbreeding and fodder production are of crucial importance for the development of livestock. This inveastigation cannot be restricted to the analysis of the acreage under fodder crops, for a simple survey of the size of the fodder-producing area cannot provide a real understanding of the feeding capacity of a region. Various types of fodder crops may yield different amounts of nutrients per unit area (1 ha). For this reason, we have tried to use the volume and composition of nutrients produced (starch value and digestible protein) as indices of the level of fodder supply for livestock and of the present-day problems of foraging.

\section{METHOD}

An examination of livestock production should start, first of all, with fodder production, i.e. with an analysis of the structure of the fodder-producing areas. Within this structure, arable fodder-land, including the fields sown with coarse grains and with rough and soft fodder crops, is most important. Natural fodder-land, meadows and pastures, plays an important role in the feeding of the livestock. Arable land and meadow-pasture combined form the main fodder-producing areas, whose composition can readily serve as an indicator of the type and trends of stockbreeding based thereon.

The analysis of the size and composition of the production area and of the structure of fodder production is only the first step in the exploration of feedstuff resources. Differences in the average yields of various fodder crops may result in a marked differentiation of the feeding capacities of particular production areas. For this reason, as already mentioned, the digestible protein 
and starch values of different feed-stuffs have been considered, because individual fodder crops contain different amounts of nutrients. The determination of the level of feed-stuff supply is not yet completed with a survey of the feedstuff reserves, as the results obtained thereby will only include the nutritive power of the main products of cropland, meadow and pasture. Main products alone are, however, insufficient for feeding livestock. Therefore, the best possible utilization of by-products such as maize-stalk, barley and oat straw, bran, parts of potatoes, sugar-beet heads and slices, and waste from the canning industry, etc. is necessary. The use of by-products in foraging is based, for the most part, on estimates. That is why an assessment of their importance is rather inaccurate. Nevertheless, by-products cannot be disregarded in fodder reserve calculations, when drawing up the feed-stuff balance. The feed-stuff balance has been drawn up on the basis of a comparison of the nutrient resources available for the needs of livestock. Feed-stuff demand has been calculated by taking into consideration the needs of livestock (in animal units) for starch and for digestible protein (Table I).

All that could managed, however, was an approximate appraisal of the feed-stuff balance, as this is controlled by a multitude of factors, such as composition of livestock by age and sex, specialization, means of feed-stuff treatment, unappraisable sources of feed-stuff, etc.

For this reason, in showing needs against the possibilities of meeting them, our statistics have been limited to livestock expressed in animal units.

\section{TABLE I.}

Annual nutrient demand of livestock (expressed in animal units) and distribution of needs by feed-stuff groups

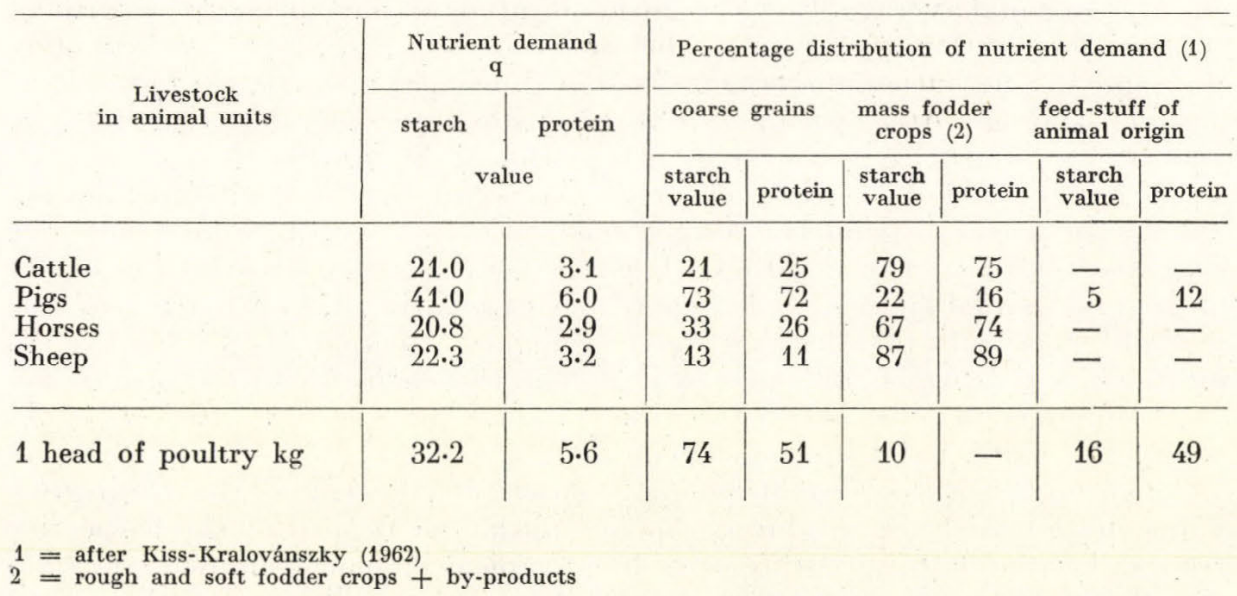

During the processing of the data, the individual animal species have been counted in absolute figures, but in the tabulation of the structure of the livestock and in the computation of the level of feed-stuff supply and of the 
feed-stuff balance, the absolute figures have been converted into animal units (one animail unit corresponds to $500 \mathrm{~kg}$ live weight). The following conversion factors have been used: 0.8 for cattle, 0.8 for horses, 0.114 for pigs, $0 \cdot 071$ for sheep.

The use of the gross production value has played an important role in this work. The gross production value expresses the combined effect of physical conditions, of the structure and technology of production and, of productivity, etc., thus making possible a real and exact comparison and evaluation of the various stockbreeding enterprises. That is why the gross production value is of great use in the classification of regions of livestock production, permitting one as it does to distinguish regional types. Besides an analysis of the gross production value, a study of market production, an important indicator of the regional relationships of stockbreeding areas, is unavoidable. A real assessment of market production, however, is rather difficult, as such an analysis can only be based on data for products purchased by the state, since sufficient information on the turnover of local markets is lacking.

The boundaries of production regions have been drawn by taking into consideration the following factors: (a) gross production value per unit area, (b) contributions of the individual animal species to the aggregate gross value of agricultural products, (c) state-purchased products per unit area, (d) share of livestock in the total of agricultural products purchased. In the controversial cases of boundary zones, the role of the individual animal species within the structure and frequency of livestock have also been taken into consideration.

The assemblage of above factors has been termed the intensity of stockbreeding and has been used for the delimitation of the livestock-producing regions, on the basis of the relationship between the given regional assemblage and the national average. Five categories of intensity have been distinguished: (1) far below national average, (2) below national average, (3) approximately the same as the national average, (4) above national average, (5) high above national average. Areas with an intensity of stockbreeding above the national average are considered to be livestock-producing regions.

The exploration of the livestock-producing regions has provided information about the areal distribution and specialization in stockbreeding, but the character of the entire livestock of particular areas, the distribution of the individual animal species, and their relative proportions, in other words, the regional types of stockbreeding have remained unexplored. To be able to establish types, we should, however, reduce the entire livestock production to a common "denominator", the gross production value, by which different production enterprises can be correlated.

An animal species accounting for at least 50 per cent of the total gross value of the livestock produced can be considered typical of the respective region. Two animal species are considered typical if their combined contribution to total gross production value is 70 per cent, but the ratio of the second animal species cannot be less than 25 per cent. A region, where the aggregate ratio of at least three animal species attains, or exceeds, 70 per cent, is of mixed type. 


\section{AREAL DISTRIBUTION AND ECONOMIC SIGNIFICANCE OF STOCKBREEDING}

Despite its considerably slower rate of development as compared with industry, agriculture still plays an important role in the Nation's economy. Whereas the output of industry in 1964 was more than four times that attained in 1949, the increase agricultural output barely exceeded 20 per cent.

Within agriculture itself, animal production has developed at a slower rate than crop production, so that this latter is invariably of greater importance than livestock production. This is readily indicated by the fact that the contribution of livestock to the total gross value of agricultural products is only $39 \cdot 8$ per cent (Table II).

TABLE II.

Animal variations in the value of gross agricultural production*

\begin{tabular}{l|c|c|c|c|c|c}
\hline \multirow{2}{*}{ Years } & \multicolumn{2}{|c|}{ M illi o n s of $\mathrm{F}$ or in t s } & \multicolumn{2}{c}{$\%$} \\
\cline { 2 - 5 } & $\begin{array}{c}\text { Crop } \\
\text { production }\end{array}$ & $\begin{array}{c}\text { Livestock } \\
\text { production }\end{array}$ & $\begin{array}{c}\text { Total } \\
\text { agricultural } \\
\text { production }\end{array}$ & $\begin{array}{c}\text { Crop } \\
\text { production }\end{array}$ & $\begin{array}{c}\text { Livestock } \\
\text { production }\end{array}$ & $\begin{array}{c}\text { Total } \\
\text { agriculture }\end{array}$ \\
\hline & & & & & & \\
1950 & 28,514 & 20,193 & 49,396 & $57 \cdot 7$ & $40 \cdot 9$ & 100 \\
1954 & 32,011 & 20,764 & 53,124 & $60 \cdot 3$ & $39 \cdot 1$ & 100 \\
1957 & 37,391 & 21,227 & 59,182 & $63 \cdot 2$ & $35 \cdot 9$ & 100 \\
1960 & 36,424 & 24,290 & 62,546 & $58 \cdot 3$ & $38 \cdot 8$ & 100 \\
1961 & 35,659 & 25,580 & 63,328 & $56 \cdot 3$ & $40 \cdot 4$ & 100 \\
1962 & 37,051 & 25,495 & 64,372 & $57 \cdot 6$ & $39 \cdot 6$ & 100 \\
1963 & 40,018 & 25,873 & 67,640 & $59 \cdot 2$ & $38 \cdot 2$ & 100 \\
1964 & 40,440 & 27,700 & 69,640 & $58 \cdot 1$ & $39 \cdot 8$ & 100
\end{tabular}

- Branches other than crop and livestock are not included.

The small share of livestock in the gross production value of agriculture is even more conspicuous when one considers that nearly 55 per cent of arable land has been devoted to supplying livestock with main product fodder, not to speak of by-products from other crops grown elsewhere.

\section{AN ACCOUNT OF FODDER PRODUCTION}

The production of fodder on cropland has shown a material expansion since the turn of the century. Whereas natural fodder land was originally more extensive than arable fodder land, 51 per cent and 49 per cent, respectively, the structure of fodder-producing areas had undergone substantial changes by 1965 , when 32.1 per cent was meadow and pasture and 67.8 per cent share of arable fodderland. The changes in the structure of the main fodder-producing areas were particularly vigorous before World War II, but the decline in meadow and pasture has been continuing ever since. 
The level of feed-stuff supply for livestock has not seemingly improved, as in the past few decades the number of livestock as a whole has remained virtually unchanged and the main fodder-producing area has not expanded either. The changes in the structure of fodder production and, more so in the volume of the nutrients produced, however, are evidence of an improvement in foraging.

A positive feature of the variation of the main fodder producing areas is that fodder output from cropland has increased, although the size of the natural fodder land has decreased. The vigorous expansion of roughages, especially of perennial rough fodder crops, is particularly welcome. Currently one-third of the cropland sown for fodder is occupied by roughages, of which nearly a half, 47.2 per cent, is perennial. Positive from the point of view of protein supply for livestock, is the gradual expansion of lucerne production. The wide use of silage, has been a stimulus to the spread of silo maize. The aggregate area of roughages has not grown because of the decrease of meadow and pasture. As a result of the increase in yields, however, the amount of nutrients produced is higher than it was earlier.

As regards coarse grains, their production has shown even more favourable changes, partly accounted by the expansion of the production area, and partly by an increase in yield. The expansion of maize is particularly remarkable, though the production of barley, a crop of higher protein content has also been widened. The high rate of development of coarse grain production is readily reflected by the structure of livestock, in which the importance of pigs has gradually increased, their rate of growth being much higher than that of cattle. Despite these developments, a negative feature of fodder production is that protein yield is not yet satisfactory.

Fodder production does not meet the requirements of up-to-date foraging either in quantity or in composition. The shortage of main product fodder is still considerable (Figs. 1, 2) and the feedstuff reserves available cannot meet demand even if the by-products are taken into account (Table III).

\section{TABLE III.}

Distribution of nutrient needs in 1965 per 1,000 tons

\begin{tabular}{|c|c|c|c|c|c|c|}
\hline \multirow{2}{*}{ Items } & \multicolumn{2}{|c|}{ Coarse grains } & \multicolumn{2}{|c|}{ Mass fodder } & \multicolumn{2}{|c|}{$\begin{array}{l}\text { Animal derived } \\
\text { fedd-stuff }\end{array}$} \\
\hline & $\begin{array}{l}\text { starch } \\
\text { value }\end{array}$ & $\begin{array}{l}\text { digestible } \\
\text { protein }\end{array}$ & $\begin{array}{l}\text { starch } \\
\text { value }\end{array}$ & $\begin{array}{l}\text { digestible } \\
\text { protein }\end{array}$ & $\begin{array}{l}\text { starch } \\
\text { value }\end{array}$ & $\begin{array}{l}\text { digestible } \\
\text { protein }\end{array}$ \\
\hline Cattle & 692.9 & 121.7 & $2,606 \cdot 4$ & $365 \cdot 3$ & - & - \\
\hline Pigs . & $2,375 \cdot 7$ & 342.9 & $716 \cdot 0$ & $76 \cdot 2$ & $162 \cdot 7$ & $57 \cdot 2$ \\
\hline Horses & $176 \cdot 3$ & $19 \cdot 4$ & $357 \cdot 8$ & $55 \cdot 1$ & - & - \\
\hline Sheep & $70 \cdot 0$ & $8 \cdot 5$ & $468 \cdot 3$ & $68 \cdot 7$ & - & - \\
\hline Poultry & 731.9 & 87.7 & 98.9 & - & $158 \cdot 2$ & 84.3 \\
\hline Total & $4,046 \cdot 8$ & $580 \cdot 2$ & $4,247.4$ & $565 \cdot 3$ & 320.9 & 141.5 \\
\hline Amount harvested & $3,856 \cdot 0$ & $403 \cdot 5$ & $2,611 \cdot 5$ & $306 \cdot 0$ & - & - \\
\hline Difference & -190.8 & $176 \cdot 7$ & $1,635 \cdot 9$ & $259 \cdot 3$ & - & - \\
\hline Deficiency or excess $\%$ & -4.7 & $-30 \cdot 5$ & -38.7 & -45.9 & - & \\
\hline
\end{tabular}




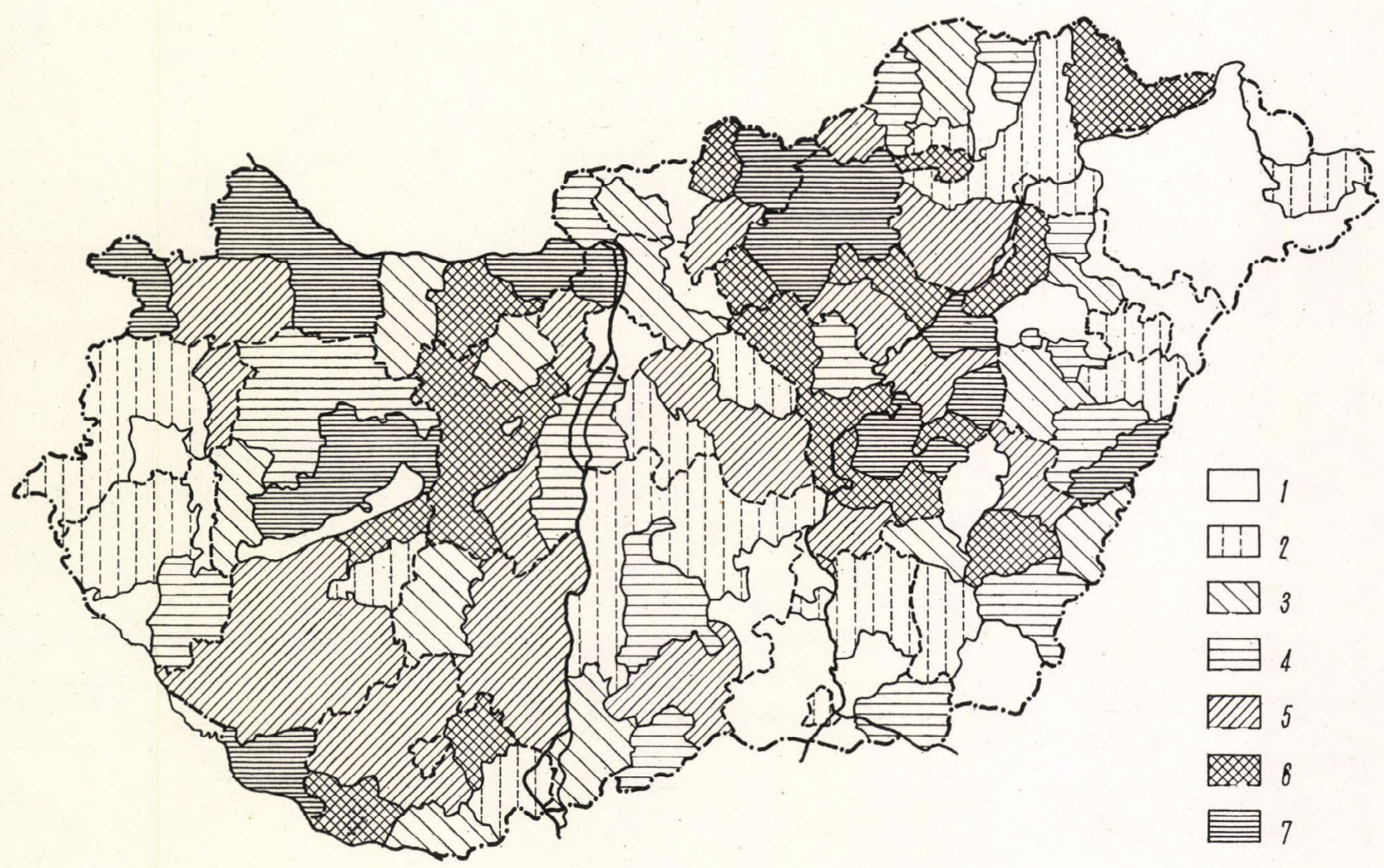

Fig. 1. Percentage coverage of protein demand as referred to total main products, $1965.1=$ below $60 ; 2=60-70 ; 3=70-75$; 


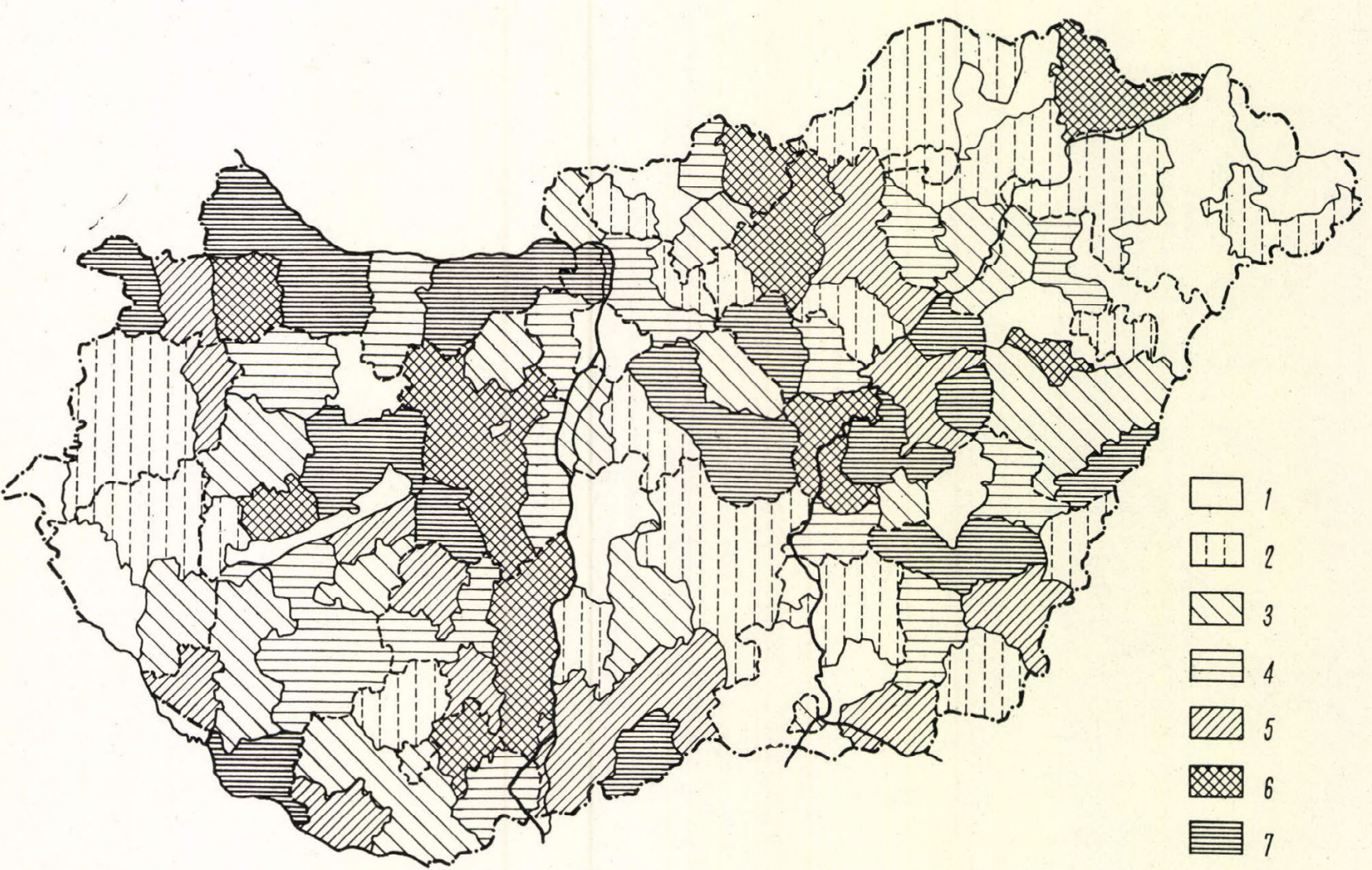

Fig. 2. Percentage coverage of starch demand as referred to total main products, $1965.1=$ below $60 ; 2=60-75 ; 3=75-80$; $4=80-85 ; 5=85-90 ; 6=90-100 ; 7=$ above 100 
The deficiency of roughages, and of protein in general, is particularly conspicuous. The absolute deficiency is, however, substantially lower than shown in the table, since during the drawing up of the fodder balance, a number of items such as aftercrops, mixture crops, kitchen middens, grass yield from road-sides and commercial feed-stuffs, etc. could not be taken into consideration, owing to the lack of information. Consequently, feed-stuff resources are more favourable than indicated.

The implications of fodder shortage, particularly the deficiency of protein for stock-breeding are obvious and result in slower animal growth and usually in lower yields. Substandard methods of foraging involve a wast of feed-stuff and this is coupled with the high cost of fodder production, due to comparatively low yields. This is not true for all fodder crops, however.

\section{THE EVOLUTION OF STOCKBREEDING AND MARKET PRODUCTION}

Livestock production has expanded during the past few decades, though this development is not reflected in the total number of livestock expressed in animal units (Table IV).

\section{TABLE IV.}

The development of livestock

\begin{tabular}{|c|c|c|c|c|c|c|}
\hline \multirow{2}{*}{ Animal types } & \multicolumn{3}{|c|}{$\begin{array}{c}\text { Number of livestock } \\
1,000 \text { head }\end{array}$} & \multicolumn{3}{|c|}{$\begin{array}{c}\text { Structure of livestock } \\
\%\end{array}$} \\
\hline & 1935 & 1960 & 1965 & 1935 & 1960 & 1965 \\
\hline Cattle & 1,911 & 1,971 & 1,964 & $58 \cdot 3$ & $55 \cdot 1$ & $54 \cdot 9$ \\
\hline Pigs & 4,674 & 5,356 & 6,963 & $18 \cdot 5$ & 21.4 & 27.7 \\
\hline Horses & 886 & 628 & 321 & $24 \cdot 6$ & $17 \cdot 6$ & $9 \cdot 0$ \\
\hline Sheep & 1,460 & 2,381 & 3,400 & $4 \cdot 6$ & $5 \cdot 9$ & $8 \cdot 4$ \\
\hline Total in animal units & 2,880 & 2,858 & 2,863 & 100 & 100 & 100 \\
\hline Poultry & 21,931 & 27,066 & 30,715 & - & - & - \\
\hline
\end{tabular}

Progress is exhibited by both the livestock structure and by an increase in the yield of animal products. An improvement of the structure of livestock is suggested by the expansion in the number of cattle and pigs, the latter increasing of the more rapid rate. The number of poultry and sheep has also increased, while horses have gradually declined. The shifts in livestock structure are, however, not satisfactory in spite of the noticeable improvement, since the ratio of cattle to the total number of animal-units hardly increased at all.

The level of livestock development is indicated, best of all, by the gross production value of one hectare of agricultural land, which averages 3,983 Ft nationally. The areal distribution of this parameter is controlled by either 


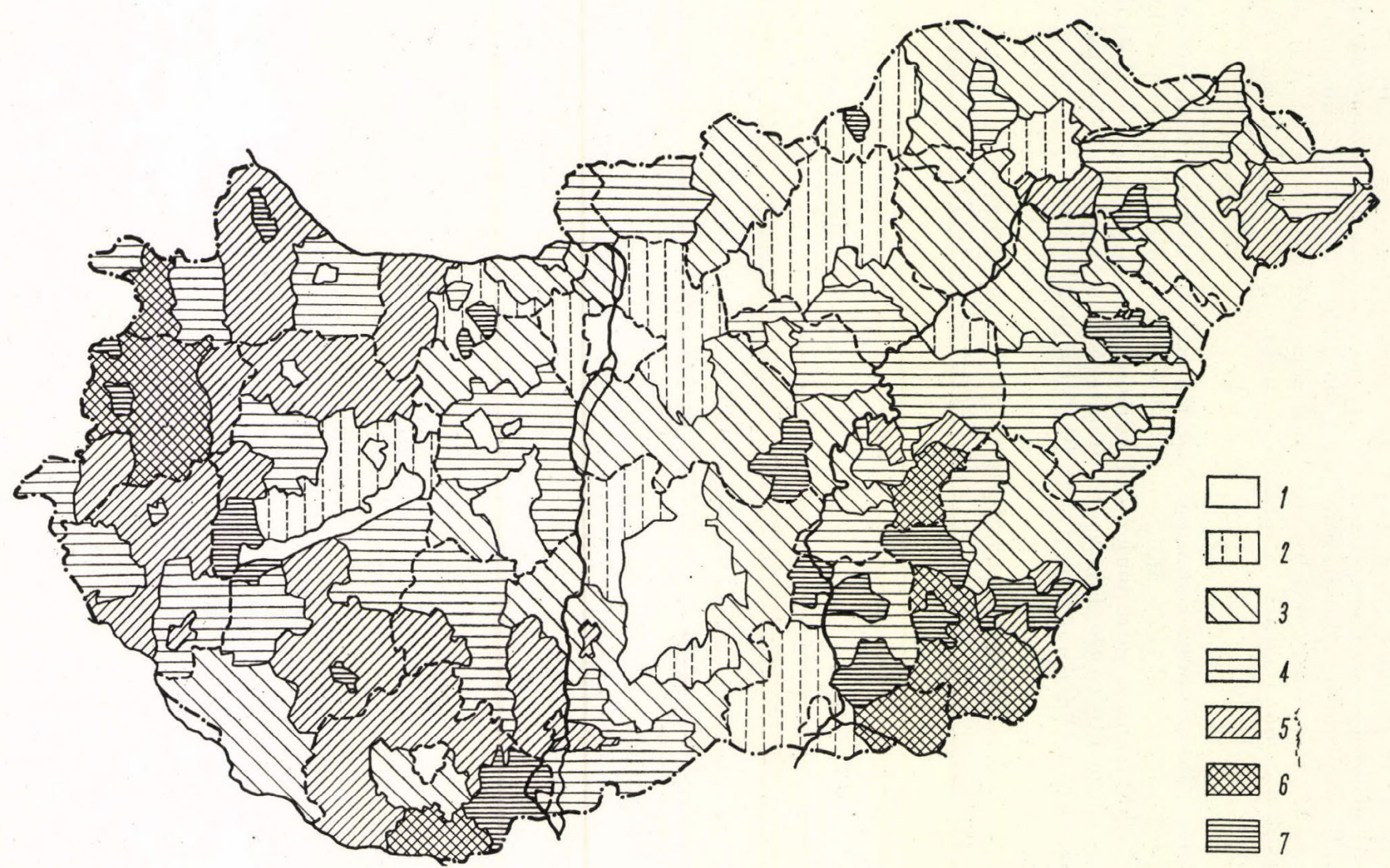

Fig. 3. Gross value of the livestock produced per ha of farm land, 1964. $1=$ below $2,200 \mathrm{Ft} ; 2=2,200-2,800 \mathrm{Ft}$; $3=2,800-3,400 \mathrm{Ft} ; 4=3,400-4,000 \mathrm{Ft} ; 5=4,000-4,600 \mathrm{Ft} ; 6=4,600-5,100 \mathrm{Ft} ; 7=$ above $5,100 \mathrm{Ft}$ 


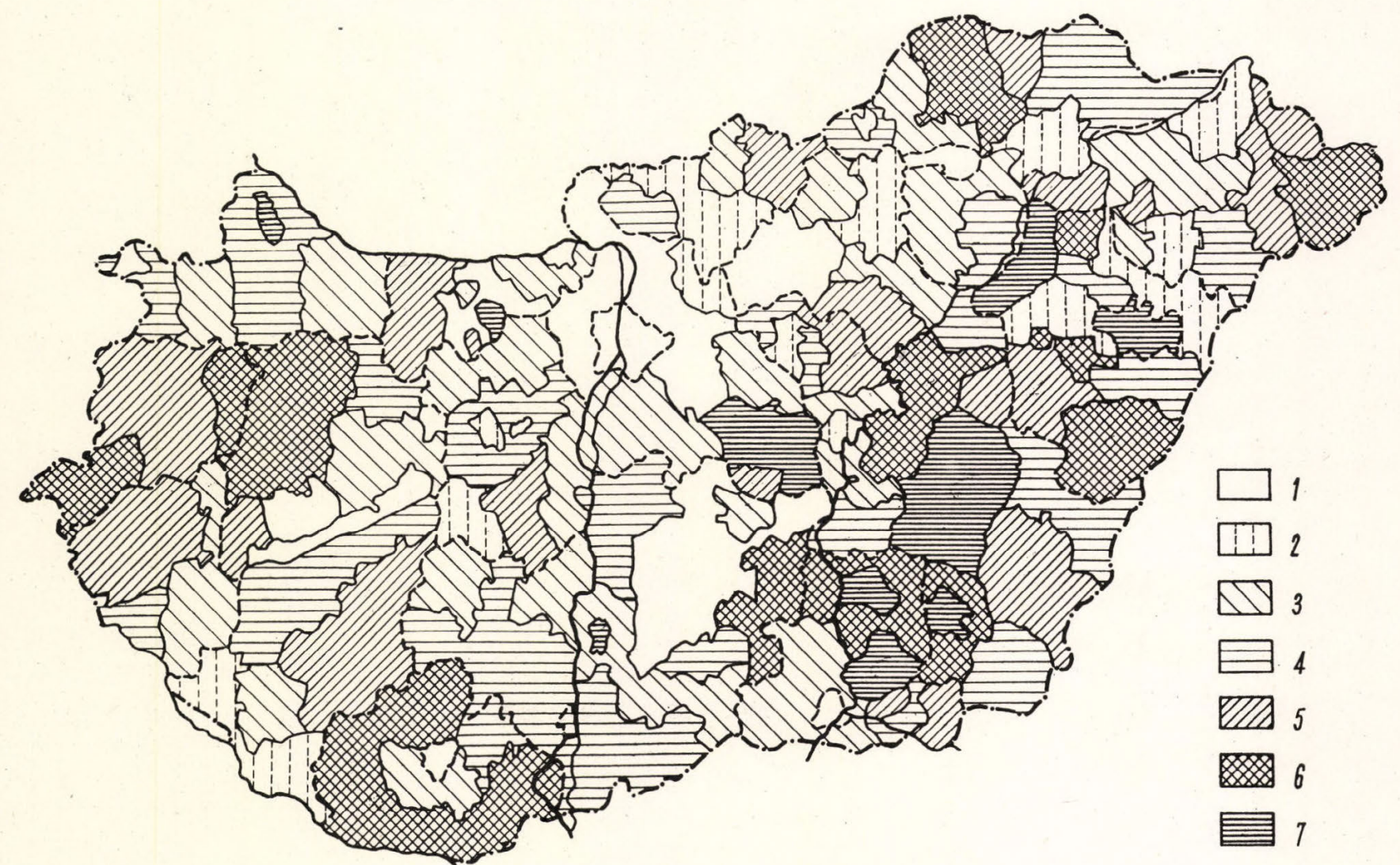

Fig. 4. Percentage ratio of the gross value of livestock produced against the total gross production value of agriculture, 1964. 
cattle or pigs, for it usually attains its highest value in those areas, where these two animals either singly or together are strikingly prominent (Fig. 3). The high values in the west part of the country are chiefly due to cattle breeding, while those in the northeast, result from pigs, cattle, and poultry. Livestock production in these areas exceeds the national average, playing a considerable part within agriculture as a whole (Fig. 4).

Crucial in cattle breeding is the problem of the comparatively large area needed for feeding the animals, as fodder crop yields are low and the technology of foraging substandard. Under present-day conditions, the production of 100 kilos of good quality meat requires 0.3 ha of fodder-producing area for pigs, 0.23 ha for poultry, and 0.75 ha for cattle. Accordingly, in the case of cattle the area needed for the production of the same amount of meat is considerably larger than for pigs, a fact largely responsible for the areal distribution of meat production in the country.

Large-scale meat production is most characteristic of the southeast part of Hungary (Fig. 5). Similar high rates of production are to be found in only a few minor areas in the rest of the country. The areal distribution of meat and other products indicates that a few regions supply the bulk of the Nation's food and satisfy the needs of foreign trade, while a large part of the country's territory makes but a low contribution.

Much is still to be done to ensure a high level of livestock production, but the role of this industry is considerable already and will grow in importance in the years to come. During the decade, beginning in 1954, the trend was steadily upwards and purchases of animals and animal products nearly doubled. On the other hand, vegetable products purchased by the state increased by only 47 per cent during the same period. The rate of increase was not continuous, however, and there were marked annual fluctuations, depending upon harvest yield. The rate of livestock purchases has thus been much higher than in the case of vegetable products; and this fact indicates that in the past decades the structure of market production has radically changed with livestock production taking over a leading role. Besides the development of livestock production and many other factors this is due to changes in the price structure. Rises in the price of slaughter cattle, milk, and pigs have enhanced the profitability of stockbreeding and have stimulated its development. On the other hand, the increase in wholesale prices has resulted in an increase of the volume of purchased goods and, consequently, the relative ratios of animal and vegetable product has changed. In 1950 total purchases of crop products amounted for 54.1 per cent, and livestock products for 45.9 per cent; in 1965 the respective ratios were 44.2 per cent and 55.8 per cent. The purchase of animals and animal products, however, increased at a rather slow but progressive rate, and did not exceed the products of crop farming until 1957 (Table V).

Pigs occupy the first place in the cash production and are followed by cattle and poultry. This order of importance is reflected in the value per unit area. As can be inferred from the above, it is meat production that is of greatest importance within the livestock market, which is also demonstrated by the fact that slaughter animals account for $40^{\circ} 0$ per cent of total agriculture purchases and the rest of all animal products for only $15 \cdot 6$ per cent. Slaughter 
TABLE V.

The composition of purchases in 1965

\begin{tabular}{|c|c|c|c|c|}
\hline Items & $\begin{array}{l}\text { Millions } \\
\text { of } \\
\text { Forints }\end{array}$ & $\begin{array}{l}\text { Ft. per } 1 \text { ha } \\
\text { farm land }\end{array}$ & $\begin{array}{l}\text { Percentage } \\
\text { referred } \\
\text { to total } \\
\text { agriculture }\end{array}$ & $\begin{array}{l}\text { Percentage } \\
\text { referred } \\
\text { to total } \\
\text { livestock }\end{array}$ \\
\hline $\begin{array}{l}\text { Pigs } \\
\text { Cattle } \\
\text { Poultry } \\
\text { Sheep } \\
\text { Horses } \\
\text { Miscellaneous } \\
\text { Total livestock } \\
\text { Total crop } \\
\text { Total agriculture }\end{array}$ & $\begin{array}{r}6,032 \cdot 5 \\
5,165 \cdot 8 \\
2,395 \cdot 6 \\
559 \cdot 2 \\
28 \cdot 3 \\
73 \cdot 0 \\
14,254 \cdot 5 \\
11,319 \cdot 0 \\
25,573 \cdot 5\end{array}$ & $\begin{array}{r}868 \\
743 \\
343 \\
80 \\
4 \\
11 \\
2049 \\
1629 \\
3678\end{array}$ & $\begin{array}{r}23 \cdot 6 \\
20 \cdot 2 \\
9 \cdot 4 \\
2 \cdot 2 \\
0 \cdot 1 \\
0 \cdot 3 \\
55 \cdot 8 \\
44 \cdot 2 \\
100\end{array}$ & $\begin{array}{r}42 \cdot 3 \\
36 \cdot 2 \\
16 \cdot 8 \\
4 \cdot 0 \\
0 \cdot 2 \\
0 \cdot 5 \\
100 \\
- \\
-\end{array}$ \\
\hline
\end{tabular}

animals account for 72.1 per cent, of all livestock purchases, and the contribution of the rest of animal products is $27 \cdot 9$ per cent.

Consequently, livestock production plays a considerable role in agricultural production for the market, but the areal distribution of livestock is strikingly differentiated. This is partly due to differences in the level of development of livestock production; on the other hand, it is largely dependent on the level of agriculture in general and of crop production in particular, i.e. on the size of the market production output of both. Hence, there are areas where though livestock production is rather advanced and the sale of livestock is great, the contribution of the livestock to total purchases from agriculture is not prominent. In contrast, there are areas where despite the low volume of livestock sales, the majority of agricultural commodities is supplied by stockbreeding (Fig. 6).

The structure of livestock production for the market shows marked differences in various parts of the country. On the basis of the volume of purchased products it can be concluded that Transdanubia is characterized by meat-and-milk production, the Great Plain by meat production (Fig. 7).

\section{REGIONS OF LIVESTOCK PRODUCTION}

The various parts of the country show striking differences in the level of development and in the type of stockbreeding. Those areas where the level of stockbreeding is higher than the national average are considered to be livestock-producing regions (Fig. 8). In Hungary, two regions of extraordinary importance can be distinguished-one in western Transdanubia and the other in the southern and central parts of the Trans-Tisza Region.

The West-Transdanubian region is characterized by cattle-breeding and subordinate pig-breeding. Stockbreeding here is of high productivity per unit area. Market production is prominent, its main enterprises being beef production and dairying. 


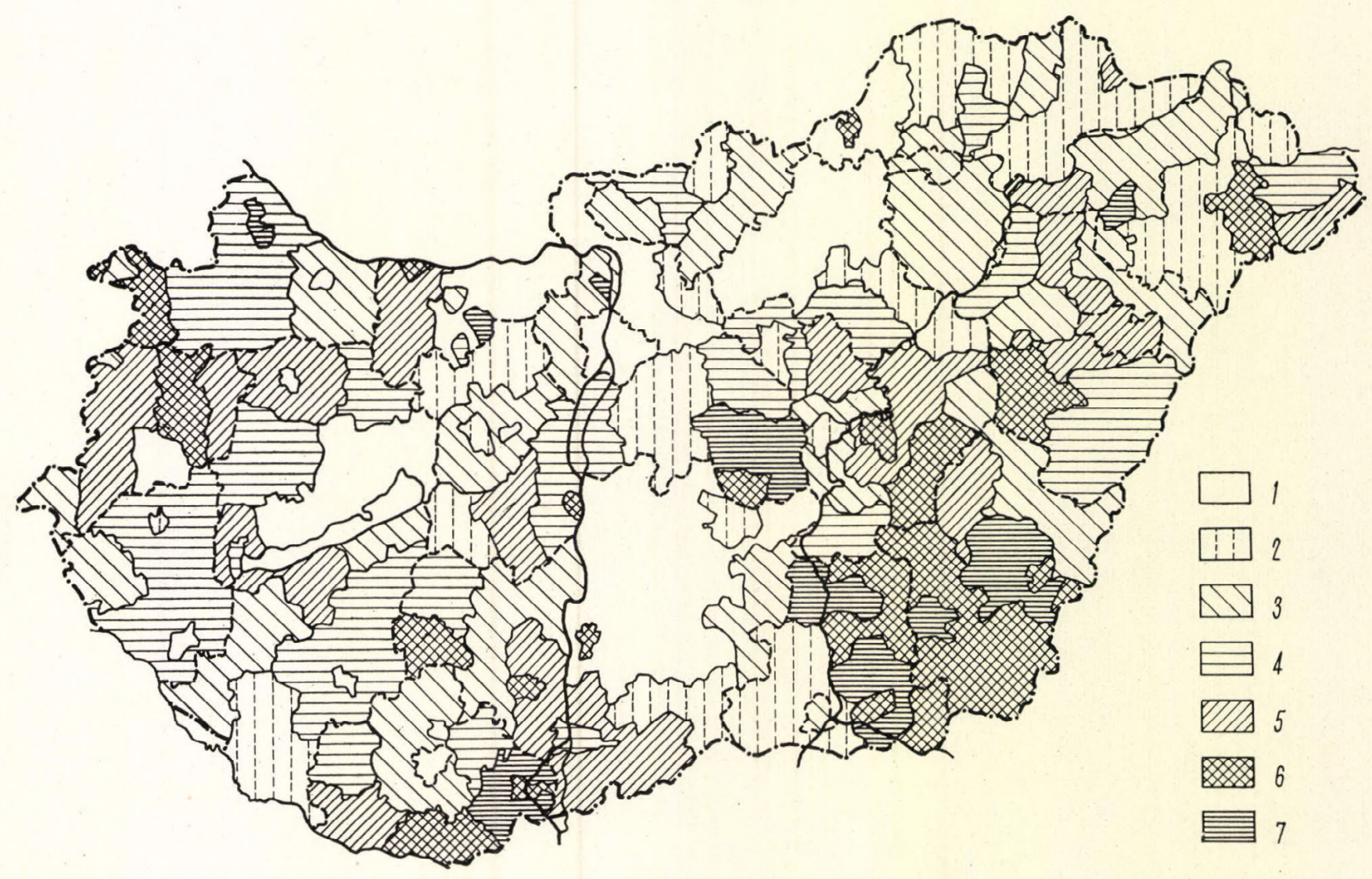

Fig. 5. Meat production per 100 ha of farm land, 1965.

$1=$ below $100 ; 2=100-130 ; 3=130-150 ; 4=150-170 ; 5=170-190 ; 6=190-230 ; 7=$ above 230 


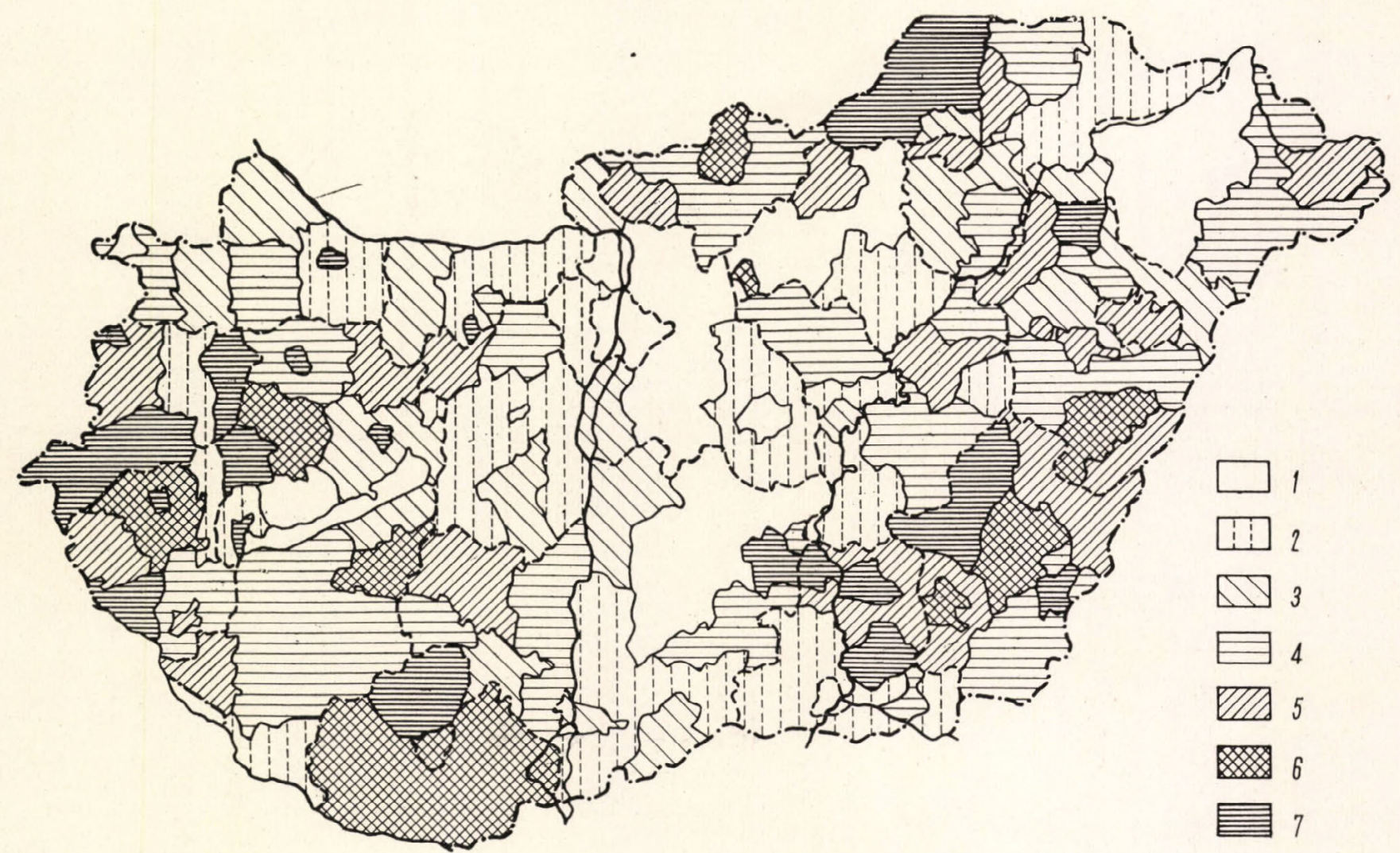

Fig. 6. Percentage ratio of animal products to total purchases from agriculture, 1965.

$1=$ below $40 ; 2=40-50 ; 3=50-55 ; 4=55-60 ; 5=60-65 ; 6=65-70 ; 7=$ above 70 


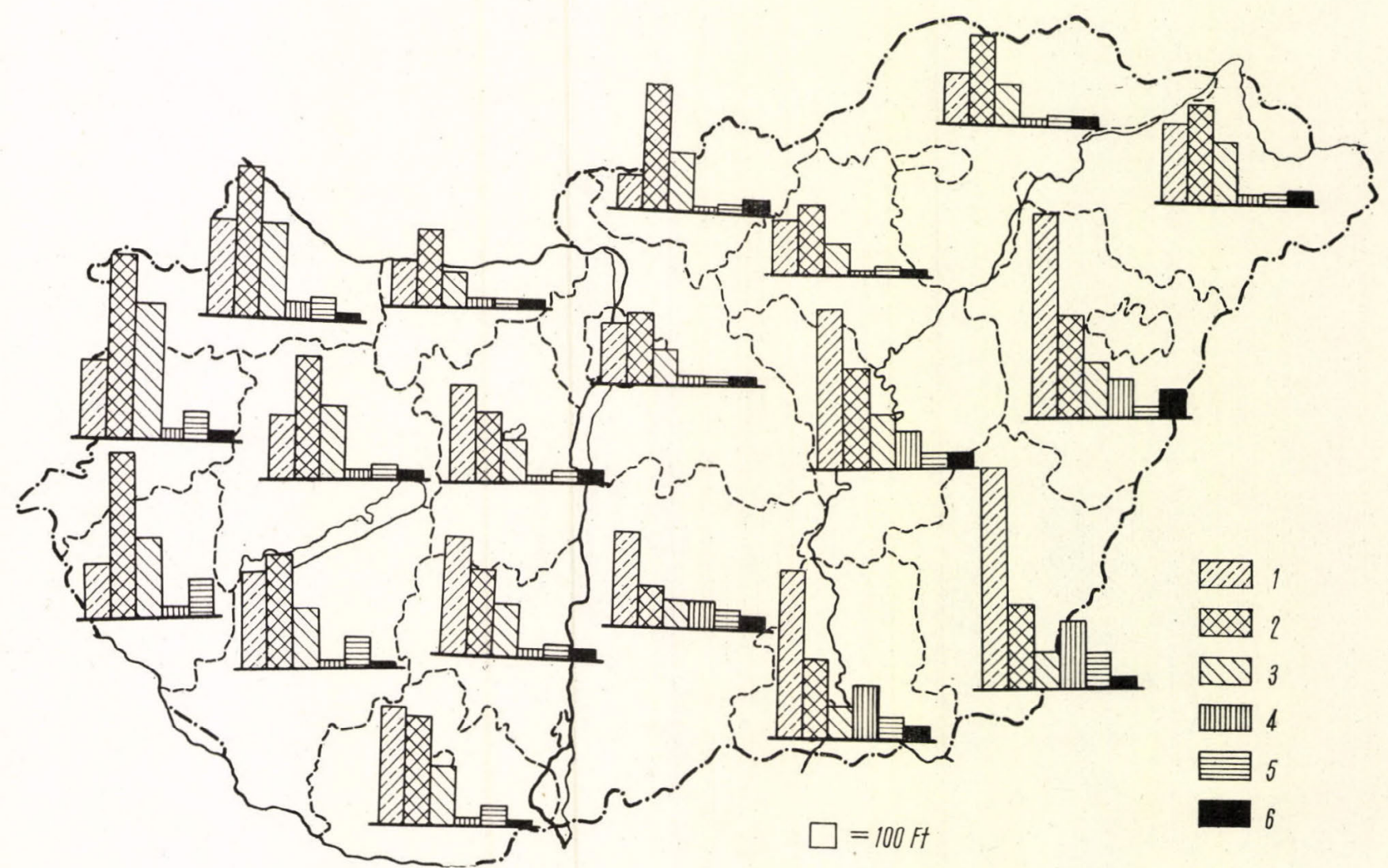

Fig. 7. Distribution of animal products purchased per ha of farm land, 1965.

1 . slaughter pig; $2=$ slaughter cattle; $3=$ milk; $4=$ poultry; $5=$ eggs; $6=$ wool and slaughter sheep 


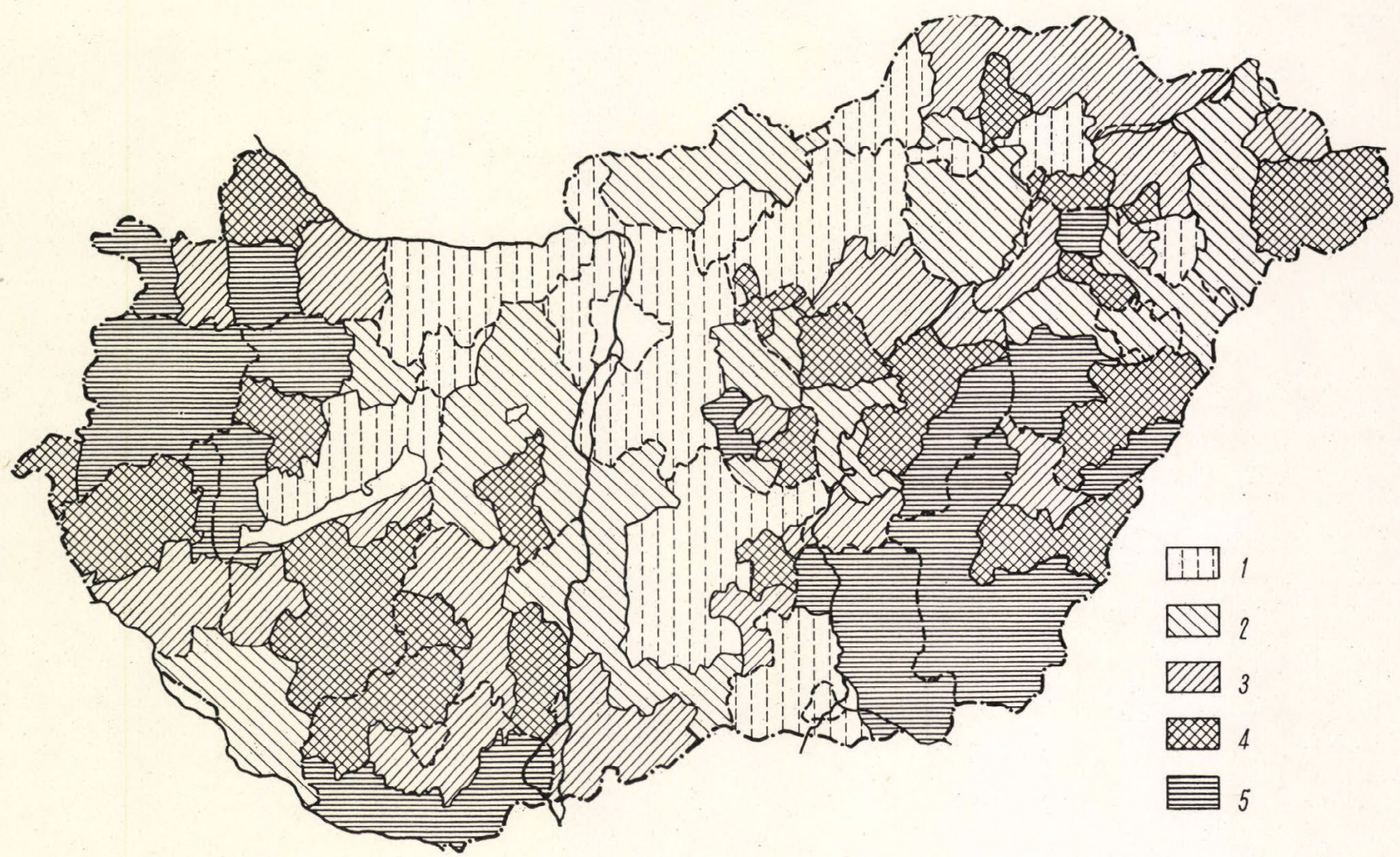

Fig. 8. Regional levels of livestock production, 1965.

$1=$ far below national average; $2=$ below national average; $3=$ around national average; $4=$ above national average; 


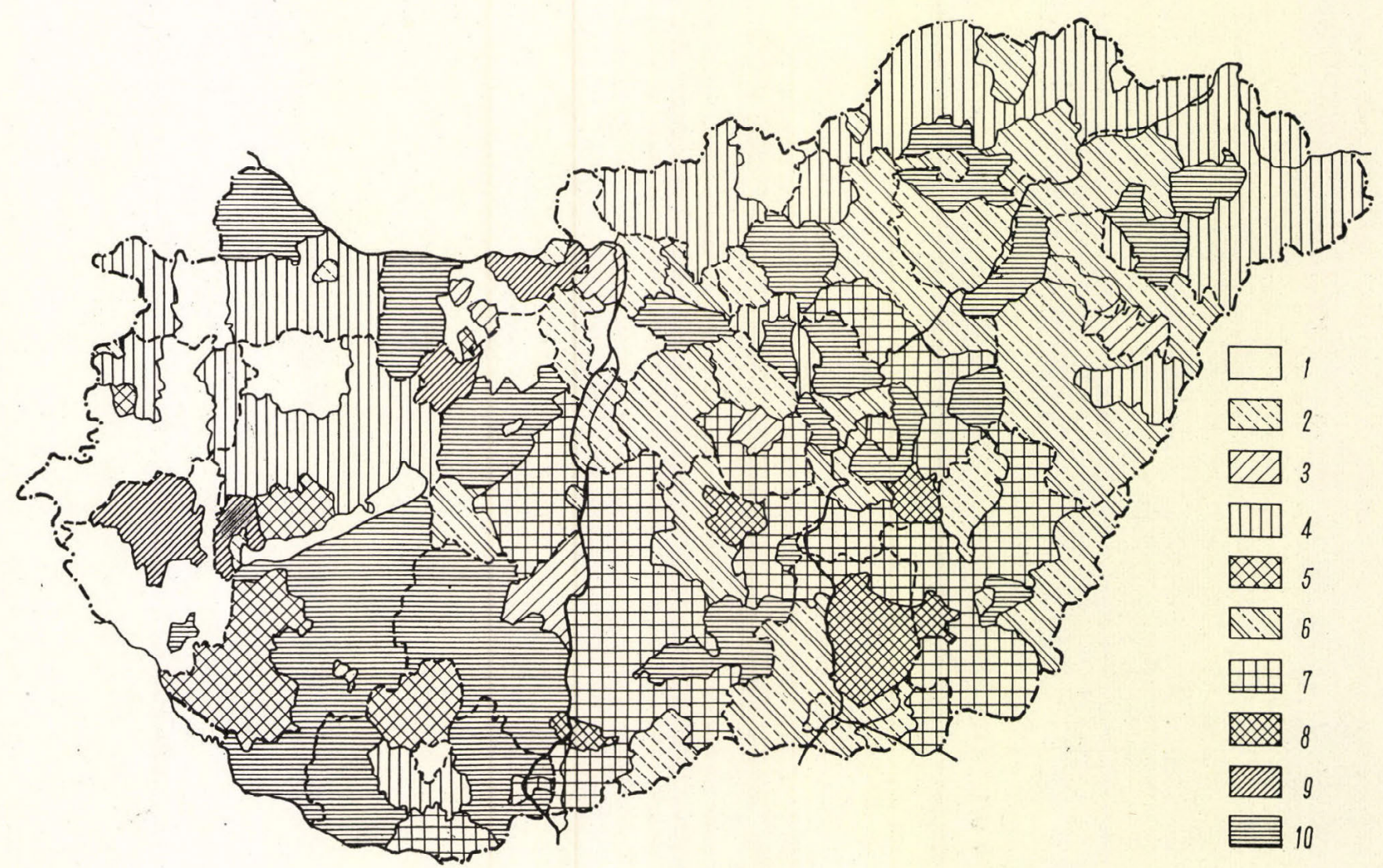

Fig. 9. Regional types of livestock production, 1965.

$1=$ cattle; $2=$ pigs; $3=$ poultry, $4=$ cattle and pigs; $5=$ cattle and poultry; $6=$ pigs and cattle; $7=$ pigs and poultry; $8=$ poultry and pigs; $9=$ poultry and cattle; $10=$ mixed 
The Trans-Tisza Region is characterized by pig and poultry production, though, in the central part, sheep-breeding is also worthy of mention. Of the marketed products, meat is the most prominent (pigs, cattle and poultry), though wool and eggs are also important.

Beside these leading regions, there are two others, one in southeast Transdanubia and one on the Szatmár Plain, which cannot be disregarded. The former is characterized by both pigs and cattle, though poultry or sheep are also significant in certain parts of the region. In the Szatmár Plain cattleand pig-breeding is characteristic.

The differenciation of livestock-producing regions has clearly demonstrated the areas of advanced stockbreeding, but has not provided a cross-section of the country's livestock production. In other words, it does not indicate the aggregate distribution of the different form animals, nor their relative proportions. The most suitable way of obtaining such information is by selecting regional types of stockbreeding. The types reflect the character of livestock production in each particular area and may provide information about the scope of further developments, and the advisable trends in specialization, which are still rather poorly advanced (Fig. 9). To promote specialization, we must meet the requirements of an up-to-date foraging technology. Livestock and fodder production are, as a rule, fairly balanced, but the present-day areal distribution has drawbacks which may, in certain areas, upset this equilibrium. Differences in the rentability of raising various types of animals may temporarily sharpen this structural contradiction. Such a tendency can be observed in the West-Transdanubian cattle-producing region where pigproduction has gradually come to the fore and has resulted in a temporary contradiction. What causes more trouble in livestock developments is not, however, this sporadic contradiction occurring within rather small areas. The main trouble stems from the fact that the feed-stuffs produced are insufficient for meeting the nutrient demand of livestock.

To keep pace with the swift growth in demand, we should develop both the quality and quantity of our livestock - a requirement presupposing an increase of fodder production and specialization and a more clear-cut differentiation of the regional types of stockbreeding, even though no radical change in the traditional regional types can be expected. Given the favourable conditions for growing roughage, it seems reasonable to improve cattle production in the Little Plain of West-Transdanubia as well. There is no need to increase the stock of pigs here, and the main developments should be of a qualitative nature. In this respect the bacon enterprise should be improved because of the production of barley and milk in the area. Accordingly, primary cattle-breeding would be associated with secondary bacon production in this type area.

Considering the conditions for foraging hill pastures in North Hungary, the cattle-and-pig type should be transformed into a more uniform cattle type of mainly beef specialization. On the Szatmár Plain too, cattle breeding with specialization in beef production should be given preference, whereas in the Nyírség's sand-covered area-because of adverse conditions for fodder production and a consequently high rate of feed-stuff imports-single-animal specialization does not seem advisable but stress should be laid upon dairying. 
On the Central Mountains foreland of Northern Hungary, a change from the pig-and-cattle type does not seem reasonable, as the two enterprises complement each other. It is, however, necessary to eliminate the mixed type in the minor areas and to develop a more definite specialization.

Large-scale grain production in the Great Plain will continue to be the basis for pig production, and the same applies to the Mezöség. Further specialization in pig breeding through bacon-and-lard cross-breeds is advisable in the southeastern part of the Great Plain, in the Danube Valley and in the Mezőföld. In addition, poultry should retain its important role. In the Middle Tisza Region and in the central Trans-Tisza Region-especially in the puszta pasture areas-large-scale irrigation development should permit the expansion of cattle-breeding, especially cattle-fattening. Favourable conditions for this are provided by the higher grass yield of the irrigated pastures-offering a cheap feed-stuff - as well as by the large-scale production of coarse grains. Consequently, this area should be transformed into a more uniform pig-andcattle type by the elimination of the mixed and poultry types. In the DanubeTisza Interfluve, the intensification of cattle-breeding is also important. The development of lucern production on irrigated sandy soils provides the necessary feed-stuffs. Owing to the higher cost of fodder production (because of the vast sand areas) and the proximity of the capital, dairy specialization rather than general cattle-breeding is recommended. The development of specialized dairy stock also seems to be advisable.

It is in southern and southeastern Transdanubia that livestock production is least specialized, though stockbreeding is well advanced. The enhancement of specialization is a prerequisite for further development. In the Mezöföld and the Dráva Valley, pig-breeding should be the primary enterprise, whereas in the Somogy, cattle-breeding is to be recommended. This would permit the elimination of the mixed type, which seems to be reasonable. In the Inner Somogy specialized slaughter cattle should be developed, in the Outer Somogy, developments in both cattle-fattening and dairying are of importance, whereas in the Kapos Valley, dairying should become the most important enterprise which, however, might be associated with large-scale bacon production.

The improvement of the areal distribution of livestock production in both quality and quantity is a long-term programme. What is required most urgently is the widening of the fodder basis, which is still rather scanty; an increase in the production of protein-rich fodder crops of high biological value; and the introduction of up-to-date methods of large-scale foraging. The economic conditions for such measures gradually become realities: the organizational framework of large-scale stockbreeding is already present; large-scale production is being developed; regional and intra-farm specializations are being improved and co-operation between the different enterprises intensified, though fullscale development is still in the future. Correct economic policy provides, however, a guarantee for the success of intensive agriculture in general and for a high standard of stockbreeding in particular. 


\section{REFERENCES}

Asztalos, I. (1963): Az állattenyésztés területi megoszlása Magyarországon (The areal distribution of stockbreeding in Hungary). Földr. Közl. 3, Vol. 11.

Asztalos, I. (1965): A takarmánytermesztés és állattenyésztés területi kapesolata Magyarországon (The areal correlation between fodder production and stockbreeding in Hungary). Földr. Ért. 1, Vol. 14.

Asztalos, I. (1964): Correlations between fodder production and stockfarming in Hungary. In: Applied geography in Hungary. Budapest: Akadémiai Kiadó.

Asztalos, I. (1966): The areal types of stockbreeding in Hungary. Geographycal types of Hungarian Agriculture. Budapest: Akadémiai Kiadó.

Bernát, T. and Enyedi, Gy. (1961): A magyar mezögazdaság termelés körzetei. I. A szántóföldi növénytermelés körzetei (Production regions of Hungarian agriculture. I. Regions of field-crop production). Budapest: Mezőgazdasági Kiadó.

Erdei, F., Csete, L. and Márton, J. (1959): A termelési körzelek és a specializáció a mezögazdaságban (Production regions and specialization in agriculture). Budapest: Közgazdasági és Jogi Kiadó.

Éber, E. (1961): A magyar állatlenyésztés fejlödése (The development of stockbreeding in Hungary). Budapest: Közgazdasági és Jogi Kiadó.

Görög, L. (1954): Magyarország mezőgazdasági földrajza (The agricultural geography of Hungary). Budapest: Tervgazdasági Könyvkiadó.

Hajas, J. and Rázsó, I. (1962): Mezögazdaság számokban (Agricultural statistics). Budapest: Mezőgazdasági Kiadó.

Kiss, P. and Kralovánszky, P. (1962): A hústermelés és húsellátás kérdései hazánkban (Problems of meat production and supply in Hungary). Budapest: Közgazdasági és Jogi Kiadó.

Magyari, Z. and Reichenbach, B. (1942): Magyarország Mezögazdasági Politikája. Alapvetés I. A szántóföldi termelés és állattenyésztés üzemi tájai (Agricultural policy in Hungary. Basic principles I. Regions of field-crop production and stockbreeding). Budapest.

Magyarország állatállománya, gazdasági gépfelszerelése és gyümölcsfaállománya az 1935. ésben (The livestock, farm machinery, and fruit tree stock of Hungary in 1935). Magyar Statisztikai Közlemények, Vol. 100, Budapest, 1937.

Magyarország gazdasági földrajza (The economic geography of Hungary), ed. S. Radó. Budapest: Gondolat Kiadó, 1963.

Megyék, párosok, járások, gazdasági körzetek adatai (Data for the counties, cities, towns, districts, and economic regions). KSH 1966.

Mezőgazdasági adatok (Agricultural statisties), Vol. I, Statisztikai Időszaki Közlemények 88, KSH 1966.

Mezögazdasági Statisztikai Zsebköny 1960 (Manual of agricultural statistics 1960). Budapest: KSH. 
Responsible for the publication: György Bernát, director of the Publishing House of the Hungarian Academy of Sciences and the Academy Press

Responsible editor: Imre Gombos

Technical editor: Mária Mezneries

Jacket design by Mária Mezneries 


\section{PREVIOUS VOLUMES OF STUDIES IN GEOGRAPHY}

Vol. 1

M. Pécsi

TEN YEARS OF PHYSICOGEOGRAPHIC RESEARCH

IN HUNGARY

In English · 132 pages · 97 figures 1 table * Bibliography $\cdot 17 \times 24 \mathrm{~cm}$ Cloth

Vol. 2

M. Pécsi, S. Marosi, etc. APPLIED GEOGRAPHY IN HUNGARY

In English · 211 pages · 76 figures 26 tables . Bibliography $\cdot 17 \times 24 \mathrm{~cm}$ Cloth

Vol. 3

I. Asztalos, Gy. Enyedi, B. Sárfalvi, L. Simon

GEOGRAPHICAL TYPES OF HUNGARIAN AGRICULTURE

In English • 84 pages · 25 figures 19 tables $\cdot$ Bibliography $\cdot 17 \times 24 \mathrm{~cm}$ Cloth

Vol. 4

LAND UTILIZATION IN EASTERN EUROPE

Edited by B. Sárfalvi

In English . 88 pages - 5 figures . 9 tables - 6 colour maps - Bibliography $\cdot 17 \times 24 \mathrm{~cm} \cdot$ Cloth

Distributors

K U L T U R A

Budapest 62. P. O. B. 149 
